Florida International University FIU Digital Commons

4-20-2018

\title{
Buffer States in Sub-Systemic Rivalries: Analyzing Nepal's Role in Sino-Indian Security Dynamics
}

Bibek Chand

Florida International University, bchan016@fiu.edu

DOI: $10.25148 /$ etd.FIDC006882

Follow this and additional works at: https:// digitalcommons.fiu.edu/etd

Part of the Asian Studies Commons, International Relations Commons, and the Other Political Science Commons

\section{Recommended Citation}

Chand, Bibek, "Buffer States in Sub-Systemic Rivalries: Analyzing Nepal's Role in Sino-Indian Security Dynamics" (2018). FIU Electronic Theses and Dissertations. 3779.

https://digitalcommons.fiu.edu/etd/3779 


\title{
FLORIDA INTERNATIONAL UNIVERSITY \\ Miami, Florida
}

\section{BUFFER STATES IN SUB-SYSTEMIC RIVALRIES: ANALYZING NEPAL'S ROLE IN SINO-INDIAN SECURITY DYNAMICS}

A dissertation submitted in partial fulfillment of the

\author{
requirements for the degree of \\ DOCTOR OF PHILOSOPHY \\ in \\ INTERNATIONAL RELATIONS
}

by

Bibek Chand 
To: Dean John F. Stack, Jr.

Steven J. Green School of International \& Public Affairs

This dissertation, written by Bibek Chand, and entitled Buffer States in Sub-Systemic Rivalries: Analyzing Nepal's Role in Sino-Indian Security Dynamics, having been approved in respect to style and intellectual content, is referred to you for judgment.

We have read this dissertation and recommend that it be approved

$\begin{array}{r}\text { Iqbal Akhtar } \\ \hline \text { Thomas A. Breslin } \\ \hline \text { Lynne M. Webb } \\ \hline \text { Félix E. Martín, Major Professor }\end{array}$

Date of Defense: April 20, 2018

The dissertation of Bibek Chand is approved.

Dean John F. Stack, Jr. Steven J. Green School of International \& Public Affairs

Andrés G. Gil

Vice President for Research and Economic Development and Dean of the University Graduate School

Florida International University, 2018 
(C) Copyright 2018 by Bibek Chand

All rights reserved. 


\section{DEDICATION}

To my beloved parents, Durga and Mohan Bahadur Chand. Without your infinite love and support, I wouldn't be where I am today 


\section{ACKNOWLEDGMENTS}

It would have been impossible to complete my dissertation without the support of several individuals and institutions. First, I would like to extend my gratitude to the Department of Politics and International Relations of the Steven J. Green of International and Public Affairs at FIU for providing funding throughout the years. Additionally, I would like to thank the University Graduate School for providing the Doctoral Evidence Acquisition Fellowship and the Dissertation Year Fellowship that tremendously helped in the completion of this dissertation. I also extend my thanks to the Morris and Anita Broad Research Fellowship from SIPA. Funding from the Graduate and Professional Student Committee, the College of Arts and Sciences, the Department of Politics and International Relations as well as SIPA and the International Studies Association have all contributed in financially aiding and making conference presentations possible, which contributed in the writing process of this dissertation.

While writing my dissertation, I was encouraged and inspired by many individuals, to whom I am deeply indebted to. Dr. Félix E. Martín, who is my advisor, has gone above and beyond to support my endeavors throughout graduate school. I would not have been successful in writing this dissertation without his consistent words of encouragement and valuable feedback. I would also like to thank my other committee members, Dr. Iqbal Akhtar, Dr. Thomas A. Breslin and Dr. Lynne M. Webb for their support throughout my writing process. Additionally, I extend my thanks to Dr. Harry Gould, Dr. Markus Thiel, and Dr. Susanne Zwingel for their support in their capacity as Graduate Program Directors of International Relations. 
Furthermore, I am thankful to Dr. Marcie Washington for always encouraging me to do my best and being a source of positivity. Dr. Ron Cox and Dr. John F. Clark have also aided me in my academic endeavors at FIU. Additionally, many thanks to the always supportive and positive team of the PIR administrative staff - María Wilkinson Díaz, Martha Rodríguez (Liranes), María Elena Gil, and Katrina Manning - thank you for always taking care of my paperwork. I would be lost without all of your love and support.

Last but not least, my heartfelt thanks to my friends Anupam Bhusal, Sewan Gurung, Liza Gashi, Maria Gabryszweksa, Chintan Bhatt, Prakash Manandhar, Biva Shrestha, Ranjita Poudel, Ana von Podcameni, Zenel Garcia, Nicolas Terradas, Dr. Lukas K. Danner, Zenel García, Onur Erpul, Mandy Guist, Chris Davis, Raquel Soto, Raquel Sedano, Siremorn Asvapromtada, Christine Bianco, Linea Cutter, Pragya Shah, Tae-whan Kim, Eunho Kim, Shipra Karmacharya, Umer Rahman, Kevin Modlin, Dhiraj Roka and Gaurav Thapa. Without all of your unending support and encouragement, I would not have come this far. Also, my parents Durga and Mohan Bahadur Chand have been more than understanding of my long absences from conversations. I do this all for you. Furthermore, my extended family including cousins Prayash, Prasanna, Prachesta, Roshan, Rakesh, Samrat, Nisha, Usha, Asha, Heema, Seema, Bikash, Binayak, Ganesh, Astha; thank you for always being there for me. Also, uncles Mohan, Bal; aunts Ishwori, Kahani, Uma; cousins-in-law Prashant, Manish, Hari, Bijay, and Tommy. Thanks to everyone else in my extended family and my undergraduate advisor Dr. Bret L. Billet for encouraging me to pursue graduate school. Lastly, I would like to convey my love and remembrance to my late uncle Madan Jung Rana, who had long desired to attend my $\mathrm{PhD}$ graduation but unfortunately passed away in the summer of 2016. I love you and miss you. 


\title{
ABSTRACT OF THE DISSERTATION \\ BUFFER STATES IN SUB-SYSTEMIC RIVALRIES: ANALYZING NEPAL'S ROLE \\ IN SINO-INDIAN SECURITY DYNAMICS
}

\author{
by \\ Bibek Chand \\ Florida International University, 2018 \\ Miami, Florida \\ Professor Félix E. Martín, Major Professor
}

This dissertation analyzes the relevance and importance of small buffer states for contemporary International Relations. It argues that sub-systemic interactions reinvigorate the role of buffer states in regional security. Using the case study of the triadic relationship among India, Nepal, and China, this study explains the evolving role of buffer states. The technological innovations in weapons systems, transportation, and communication have extended the reach of potential adversaries, rendering intermediate territorial space less significant than in the past. Thus, it is hypothesized in this dissertation that increased subsystemic rivalry reinvigorates differently the relevance and significance of buffer states. The role of such states has evolved from an overwhelmingly geographic concept based on spatial discontinuity between larger rival powers to that of a fluid political space in which Great/Middle Power rivalry and competition play out.

The research utilizes a mixed research design, specifically called the convergent parallel design. Data was collected based on specific critical junctures between 1990-2017. For quantitative analysis, data on trade, foreign direct investment, and foreign aid were collected; for the qualitative data analysis, foreign policy statements, press releases, and 
media briefs were used. Incorporating the Kruskal-Wallis Test and content analysis, both the results of the qualitative and quantitative analyses were collectively interpreted. Results demonstrate that during critical historical junctures, material and rhetorical engagements of both China and India invigorate within the buffer state of Nepal. In periods that India increases its material and rhetorical engagements, China concomitantly decreases its material engagement all the while increasing its rhetorical engagement. In essence, buffer states maintain relevance through the externalization of interactions between larger powers in the form of dynamic rhetorical and material engagements. In this case, Nepal maintains its relevance as a dynamic political space for interactions between its neighbors, India and China. 


\section{TABLE OF CONTENTS}

CHAPTER

PAGE

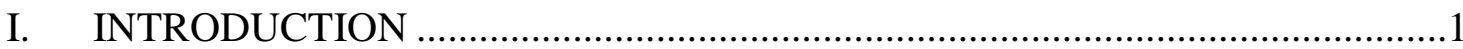

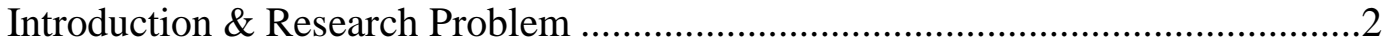

Statement of Purpose ...................................................................................

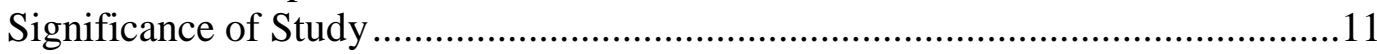

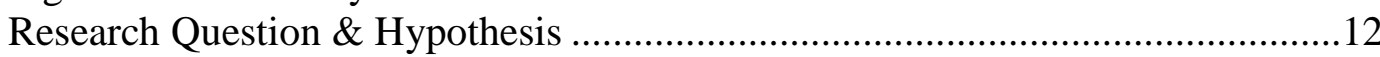

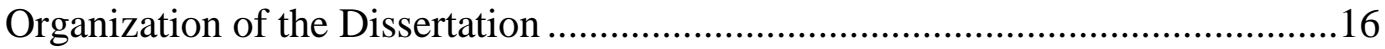

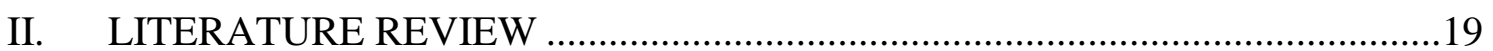

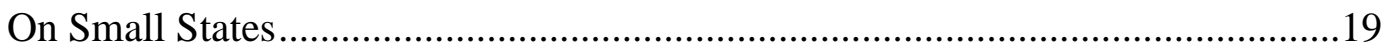

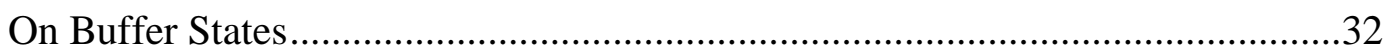

On Sub-Systemic Powers, Rivalry, and Geographic Contiguity ...........................45

On the Continued Relevance and Utility of the Buffer State Concept in

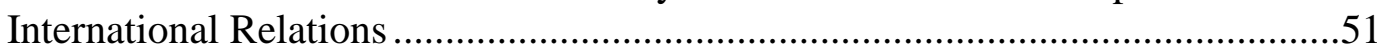

III. RESEARCH DESIGN, CASE SELECTION, \& METHODOLOGY ....................60

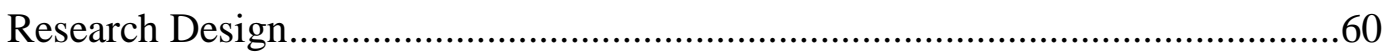

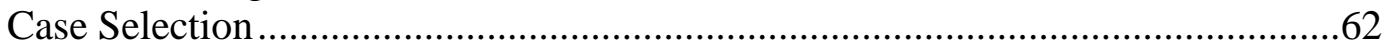

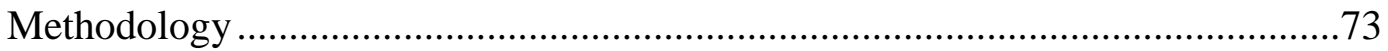

Quantitative Data Collection and Analysis..............................................80

Qualitative Data Collection and Analysis.................................................84

IV. CRITICAL JUNCTURES IN THE INDIA-NEPAL-CHINA BUFFER

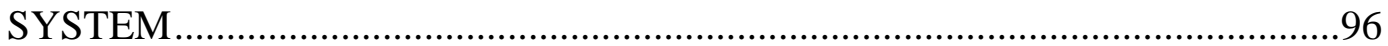

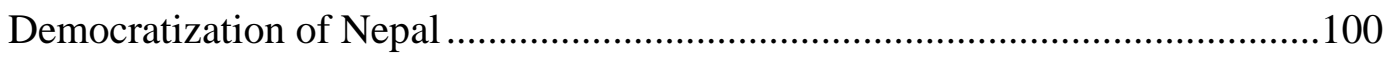

Nepalese Royal Family Massacre ......................................................................103

Suspension of Parliamentary Democracy in Nepal ..........................................106

Riots in the Tibetan Autonomous Region.........................................................109

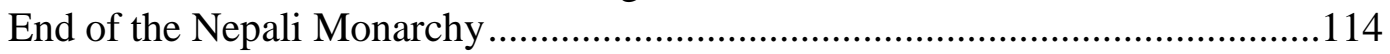

The Nepal Earthquakes .....................................................................................118

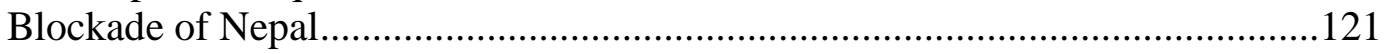

Nepal's Entry into China's Belt and Road Initiative ........................................125

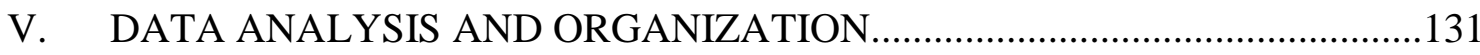

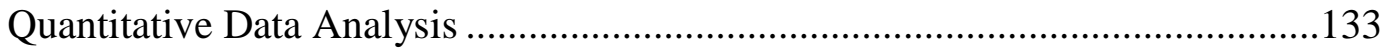

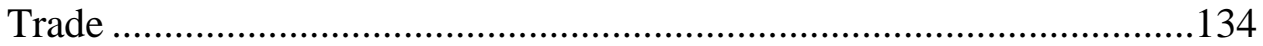

Foreign Direct Investment (FDI) .........................................................140

Foreign Aid ....................................................................................144

Non-Parametric Correlations .................................................................152 


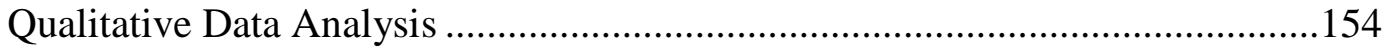

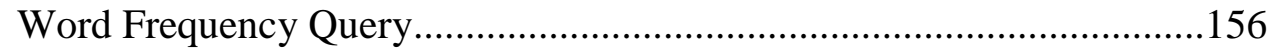

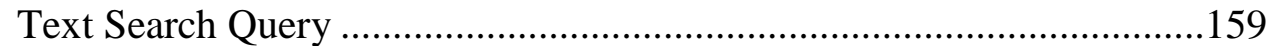

Organization of Analyzed Data Results.........................................................163

Quantitative Data Analysis Results ..................................................163

Qualitative Data Analysis Results ..................................................165

VI. COLLECTIVE INTERPRETATION OF RESULTS ....................................167

Comparison of Qualitative and Quantitative Analyses.....................................168

Convergence/Divergence of Analyses and Merging of Results .........................174

Results for India-Nepal Engagements ................................................174

Results for China-Nepal Engagements ............................................175

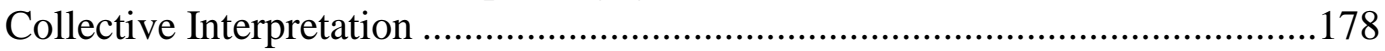

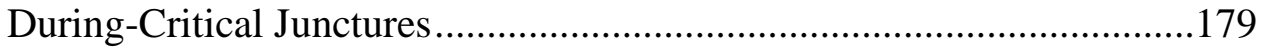

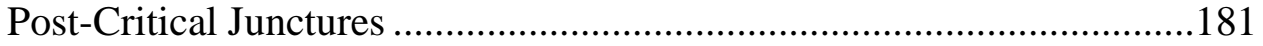

Interpretation of Overall Patterns........................................................183

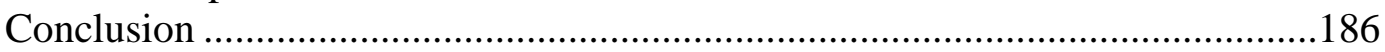

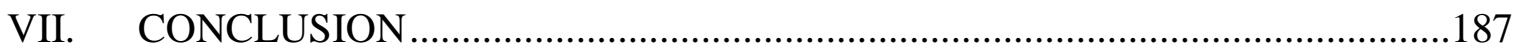

Revisiting the Research Question and Hypotheses...............................187

Major Insights from the Study .....................................................192

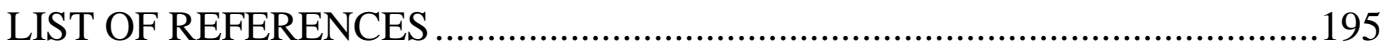

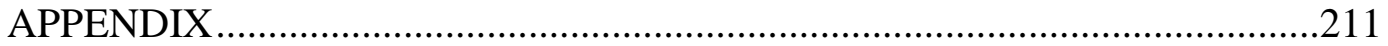

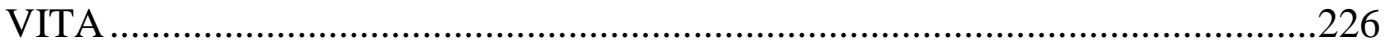




\section{LIST OF TABLES}

TABLE

PAGE

1. Historical Critical Junctures in Triadic Relations between India, China, and

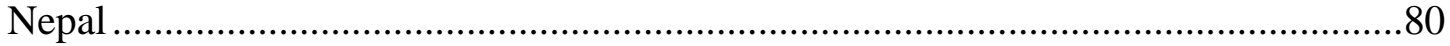

2. Mapping of the Critical Junctures in the India-Nepal-China Buffer System (1990-2017).

3. Results of the Word Frequency Queries

4. Overall Results of the Quantitative Data Analysis

5. Overall Results of the Qualitative Data Analysis 166

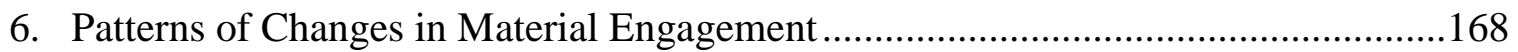

7. Patterns of Changes in Rhetorical Engagement 169 


\section{LIST OF FIGURES}

FIGURE

PAGE

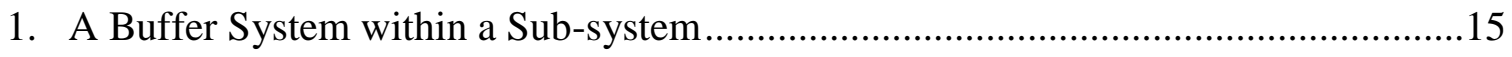

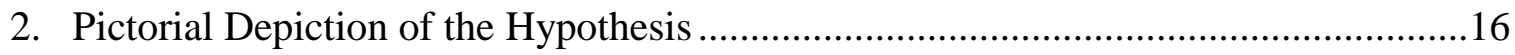

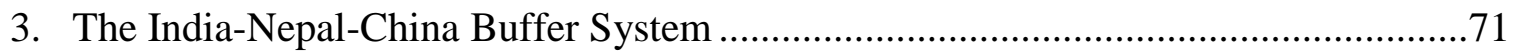

4. Map of the India-Nepal-China Buffer System .....................................................72

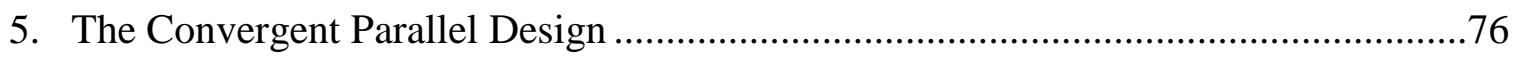

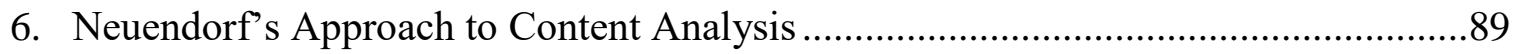

7. Convergent Parallel Design used for the India-Nepal-China Buffer System ..............95

8. Donnelly and Hogan's Conception of Critical Junctures .........................................99

9. Modified Conception of Critical Junctures .........................................................99

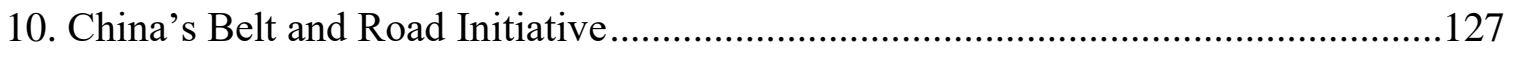

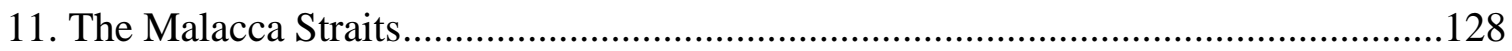

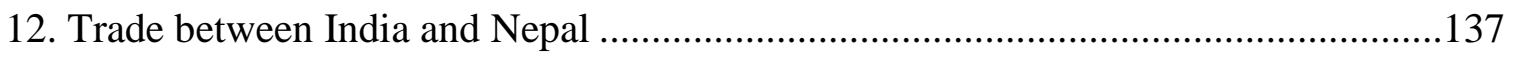

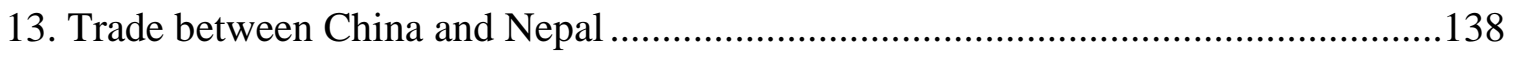

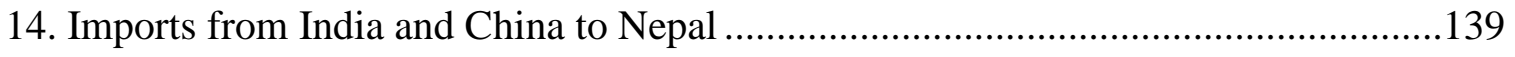

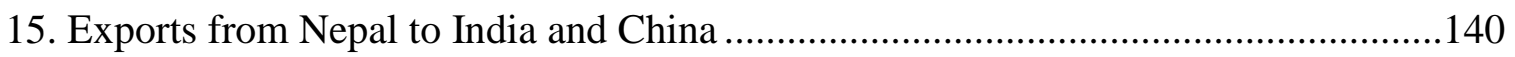

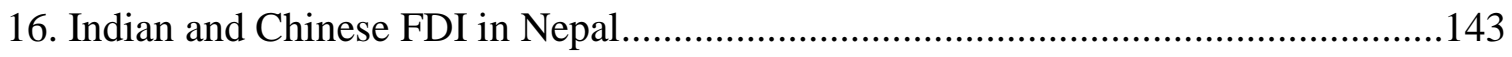

17. Foreign Aid from China and India for Nepal...................................................149

18. Comparative Trends in Analysis of Material Engagement .....................................151

19. Results for the Text Search Queries for Positive Affirmations of all Qualitative Data ............................................................. 160 
20. Results for the Text Search Queries for Negative Affirmations of all Qualitative

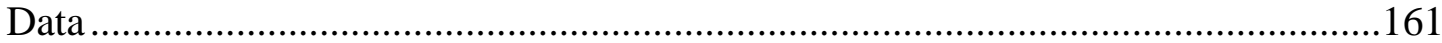

21. Comparison of Text Search Queries for Positive and Negative Affirmations............161 


\section{LIST OF ACRONYMS}

\begin{tabular}{|c|c|}
\hline $\mathrm{BRF}$ & Belt and Road Forum \\
\hline BRI & Belt and Road Initiative \\
\hline CPA & Comprehensive Peace Agreement \\
\hline CPN-M & Communist Party of Nepal - Maoist \\
\hline CPN-UML & Communist Party of Nepal - Unified Marxists-Leninists \\
\hline FDI & Foreign Direct Investment \\
\hline INCBS & India-Nepal-China Buffer System \\
\hline KWT & Kruskal-Wallis Test \\
\hline MEA & Ministry of External Affairs \\
\hline MoFA & Ministry of Foreign Affairs \\
\hline $\mathrm{MoU}$ & Memorandum of Understanding \\
\hline $\mathrm{NC}$ & Nepali Congress \\
\hline ODA & Official Development Assistance \\
\hline OPEC & Organisation for Economic Co-operation and Development \\
\hline PRC & People's Republic of China \\
\hline SPA & Seven Party Alliance \\
\hline TAR & Tibetan Autonomous Region \\
\hline UANOVA & Univariate Analysis of Variance \\
\hline UDMF & United Democratic Madhesi Front \\
\hline UNICEF & United Nations Children's Fund \\
\hline
\end{tabular}




\section{CHAPTER I: INTRODUCTION}

"A swan," said the Ameer, "was once swimming in a pond, watched with hungry eyes from one bank by a pack of wolves, and from the other by an old tigress. From fright or curiosity, the swan incautiously approached the latter. The tiger clawed at him and tore out some of his feathers. In his distress he swam over to the other bank, when the wolves made a rush and would have torn him to pieces, had he not escaped into deep water. Finding himself secure, he resolved to confine his movements to the middle of the pond. There resting at his ease, he noticed how the wolves snarled at each other, and how very shallow the water was near the edge. He reflected that were the pond to dry up, the tigress might and the wolves certainly would devour him." ${ }^{1}$

- Abdur Rahman Khan, Ameer of Afghanistan (1880-1901)

${ }^{1}$ Stephen Wheeler, The Ameer Abdur Rahman (London, UK: Bliss, Sands, and Foster, 1895), 137. 


\section{Introduction \& Research Problem}

The discipline of International Relations has been mostly preoccupied with the political dynamics of the Great Powers. ${ }^{2}$ Conversely, small states have been relegated to a peripheral role and inconsequential position within the discipline. Their analytical utility has not been extensively explored, as the emphasis has been largely placed on the study of Great Powers. ${ }^{3}$ Analytical neglect of small states may prevent a comprehensive understanding of the processes of war and peace as well as stability and instability in the international system. Such neglect poses a problem as it undervalues the role played by smaller powers in Great and Middle Power interactions in critical periods in the international system, ranging from the Napoleonic Wars ${ }^{4}$ to the end of the Cold War. ${ }^{5}$ From

2 Niels Amstrup, "The Perennial Problem of Small States: A Survey of Research Efforts," Cooperation and Conflict 11, no.2 (1976): 163; Christos Kassimeris, "The Foreign Policy of Small Powers," International Politics 46, no. 1 (2009): 84-85.

${ }^{3}$ Robert Rothstein, Alliances and Small Powers (New York, NY: Columbia University Press, 1968), 2 - Rothstein alludes to the obscurity of small states in the traditional literature of International Relations as the international system is organized as a hierarchy, which means that small states are the bottom of such a hierarchy and are rendered as inconsequential. He argues that small states should not be analyzed only through this hierarchical lens but as political entities with unique patterns of behavior; Michael I. Handel, Weak States in the International System (New York, NY: Frank Cass, 1990), 3 - Handel laments over the basis of International Relations theories on relations among Great Powers and the relative lack of emphasis on weak states;

Wouter P. Veenendaal and Jack Corbett, "Why Small States Offer Important Answers to Large Questions," Comparative Political Studies 48, no.4 (2015): 528 - Veenendaal and Corbett argue that the peripheralization of small states is also commonplace in comparative political research and as such, support the claim that small states are largely ignored in the wider discipline of Political Science. Their argument is largely methodologically grounded, addressing the issue of not including the small states in analyses. Such states could provide insight into whether the "smallness" of such states can offer alternative insights or support claims within comparative political analyses that are extensively based on the larger states in the international system.

${ }^{4}$ Matthias Maass, Small States in World Politics: The Story of Small State Survival, 1648-2016, 1st ed. (Manchester: Manchester University Press, 2017);

The Napoleonic Wars witnessed the dramatic demise of small states; they fell from 339 in 1792 to 79 in 1814 - a fall by approximately eighty percent. The Napoleonic Wars initiated the demise of small states in the international system, significantly altering the geopolitical space of Europe (and beyond).

5 Ibid., 183-84; 
proxy wars to buffer zones, small states in the international system have continually fulfilled critical functions as interactive geopolitical spaces for Great Power relations. Furthermore, small states are essential and intrinsically valuable for the international state system as they are the minor yet important political players in effectively balancing larger powers, when needed. ${ }^{6}$ Among the wide range of functions such states fulfill, ${ }^{7}$ the role of a buffer state is crucial given its strategic interest for larger powers and relevance for regional patterns of stability and instability. Such small states played historically relevant roles in the strategic calculations of the Great Powers, including empires of the British and the Russians in the $19^{\text {th }}$ and early $20^{\text {th }}$ centuries. ${ }^{8}$ In the simplest of terms, buffer states are small states straddled between rival Middle or Great Powers. These are states that "lessen the shocks emanating from some mightier state in the process of violent upheaval." ${ }^{\text {John }}$

The Cold War, while systemically stable, proved to be highly unstable for the smaller states in the international system. Characterized by proxy wars fought by the US and USSR, small states emerged as the geopolitical space wherein the Cold War played out. From the Central America to Africa, small states became frontiers for intrastate wars fueled and sometimes, directed by the two superpowers.

${ }^{6}$ Herbert Butterfield, "The Balance of Power," in Diplomatic Investigations, Essays in the Theory of International Politics, eds. Herbert Butterfield and Martin Wright (Cambridge, MA: Harvard University Press, 1968).

${ }^{7}$ Small states fulfill an array of functions ranging from buffers, proxies, bulwarks against a rival, or part of larger geopolitical conceptions of shatterbelts and buffer zones. They may constitute instrumental roles in alliance formations as well.

${ }^{8}$ Tanisha M. Fazal, State Death: The Politics and Geography of Conquest, Occupation, and Annexation (Princeton, NJ: Princeton University Press, 2007), p.70; David Fromkin, "The Great Game in Asia," Foreign Affairs 58, no. 4 (1980): 936-51; Miron Rezun, "The Great Game Revisited," International Journal 41, no. 2 (1986): 324-41;

During the Great Game of the $19^{\text {th }}$ Century, the British and Russian mistrust of each other's imperial ambitions evolved into a geopolitical tussle in Central Asia, particularly in Afghanistan. It was largely a manifestation of British concerns regarding Imperial Russia's southward expansion into Central Asia. The region was close to Britain's Crown Jewel - India. Thus, the mistrust between Imperial Russia and the British Empire manifested itself into a geopolitical tussle, largely in Afghanistan and Iran. Fromkin sums it well "...there always was a body of opinion in Britain that saw in every Russian move in Asia a threat to Britain's interest in India, no matter how farfetched that might seem to be as an analysis of the motives behind the Russian move in question."

${ }^{9}$ Anicetas Simutis, “Buffer States: A Worn-out Myth,” America 70, no. 14 (1944): 376. 
Chay and Thomas E. Ross's 1986 edited book titled Buffer States in International Politics ${ }^{10}$ offers the most comprehensive account of buffer states in the international system - one of the few that directly covers buffer states. Chay and Ross define such states as "countries geographically and/or politically situated between two or more large powers whose function is to maintain peace between the larger powers."11 Tanisha M. Fazal, in her work State Death: The Politics and Geography of Conquest, Occupation, and Annexation, defines a buffer state as a "state geographically located between two other states engaged in a rivalry, unless the rivals are separated by an ocean."12 Thus, buffer states are instrumental in the maintenance of regional stability and peace as they are situated in geopolitically sensitive areas, where rivalries are intense. As Faizal notes, buffer states are specifically tied to land based geographic contiguity.

This dissertation addresses the buffer function of a small power within the context of its evolving role, as regional approaches to security through sub-systemic ${ }^{13}$ analysis expands within International Relations. It seeks to reinvigorate the concept of the buffer state within the current context of the field of International Relations. Although small states do not garner much attention within the discipline, this dissertation delves into one of their historically significant functions i.e. acting as buffers between rival interests.

\footnotetext{
${ }^{10}$ John Chay and Thomas E. Ross. Buffer States in World Politics (Boulder, CO: Westview Press, 1986).

${ }^{11}$ John Chay and Thomas E. Ross, "Preface," in Buffer States in World Politics, eds. John Chay and Thomas E. Ross (Boulder, CO: Westview Press, 1986), xiii.

12 Tanisha M. Fazal, State Death: The Politics and Geography of Conquest, Occupation, and Annexation (Princeton, NJ: Princeton University Press, 2007), p.70.

${ }^{13}$ A sub-system, in the context of this dissertation, entails the regional level of analysis. As such, sub-systemic approach to security entails the study of regional security studies.
} 
Among others, scholars such as Amitav Acharya, T.V. Paul, Ole Wæver, and Barry Buzan $^{14}$ have conceptualized and promoted sub-systemic approaches to security, highlighting the importance of regional powers. Sub-systemic analyses provide a more localized and diffused extrapolation of security, which accounts for local power dynamics. Sub-systems are regional or localized components of the international system, which are generally characterized by "one state or two or more geographically proximate and interacting states which share in some degree common ethnic, linguistic, cultural, social and historical bonds and whose sense of identity is sometimes increased by the actions and attitudes of states external to the system." ${ }^{15}$ Godehardt and Nabers (2011) conceptualized the sub-system as not just a microcosm of the international system; sub-systems may not always adopt the functions of the international system and may include their own rules of engagement in the regional context. ${ }^{16}$ As such, regional political dynamics may take on peculiar characteristics. An approach based solely on systemic analysis may not adequately depict regional patterns of security issues, including rivalrous relationships between

${ }^{14}$ For more on the increasing interest on sub-systems, see the titles T.V. Paul, International Relations Theory and Regional Transformation (Cambridge, UK: Cambridge University Press, 2012); Barry Buzan and Ole Wæver, Regions and Powers: The Structure of International Security (Cambridge, UK: Cambridge University Press, 2003); Barry Buzan, "The South Asian Security Complex in a Decentring World Order: Reconsidering Regions and Powers Ten Years On," International Studies Quarterly 48, no.1 (2011): 1-19; Nadine Godehardt and Dirk Nabers, Regional Powers and Regional Orders (New York, NY: Routledge, 2011).

${ }^{15}$ Louis J. Cantori and Steven L. Spiegel, "International Regions: A Comparative Approach to Five Subordinate Systems," International Studies Quarterly 13, no.4 (1969): 362;

Cantori and Spiegel use the terminology "subordinate systems" to refer to sub-systems. In more contemporary works in International Relations, sub-system has attained popularity over subordinate system. As such, this dissertation will use sub-system over subordinate system although the underlying concept is the same. Refer to Patnaik (1980), Shaw (1974) \& Krishnan and Dhal (2014) for examples of the usage of subsystemic approaches in International Relations.

\footnotetext{
${ }^{16}$ Nadine Godehardt and Dirk Nabers, Regional Powers and Regional Orders (New York, NY: Routledge, 2011), 1.
} 
regional powers. Additionally, regional approaches to security allow closer extrapolations of the role played by smaller states, whose roles may be significant regionally but inconsequential systemically. Buffer states are part of such regional security configurations wherein they play a significant geopolitical role locally but may not be strategically important at the systemic level. In essence, buffer states are demarcations or territorial cushions between rival powers and are relevant in regional security dynamics.

In the modern nation-state system, the British Empire was at the forefront in using buffer zones and buffer systems ${ }^{17}$ among several other strategies to ensure the territorial security of its imperial possessions. Afghanistan, Nepal, and Tibet functioned as buffer states for the British Empire in India, separating it from Qing China in the north and the Russian Empire in the west. ${ }^{18}$ Such buffer states fulfilled the function of geographic barriers against rivals or competing empires, while further functioning as early warning systems against any foreign incursions. The British line of thinking on the usage of buffer states was consistent with the primacy of geographic distance as a strategy for spatial security, which was prized as a strategic advantage up to the First World War. Military geography, which describes the military capabilities of a state and the way its assets are deployed, had long emphasized the importance of geographic obstacles such as distance

${ }^{17}$ John Chay and Thomas E. Ross, "Introduction," in Buffer States in World Politics, eds. John Chay and Thomas E. Ross (Boulder, CO: Westview Press, 1986), 2 - Chay and Ross interpret a buffer system as a political organization that could consist of the buffer state and the larger powers it separates. It could also mean a group of states that can serve as a buffer between rival areas of influence; Eastern Europe as a buffer zone between Western Europe and Russia is an example of such a buffer system. The British were at the forefront of using buffer zones, a policy that was explicit since the Great Game with Imperial Russia. Simply put, a buffer system constitutes the buffer state and the two larger rivalrous powers (buffered states) that it separates.

18 Thomas E. Ross, "Buffer States: A Geographer's Perspective," in Buffer States in World Politics, eds. John Chay and Thomas E. Ross (Boulder, CO: Westview Press, 1986): 20-21. 
and high mountain chains. ${ }^{19}$ Due to advent of the air force and missile technologies since the First World War, the utility of geographic distance has decreased in importance. Geopolitical distance could no longer be used as a strategic tool to "buy time" during conflicts. The buffer state has also lost its utility as an early warning system -- traditionally, movement of land-based militaries across buffer states could give the core additional time and space to prepare for the conflict. Advancement of military technology largely impacted the utility of geographic space as a tool for enhancing state security, which entailed securing the core.

The classical approach to buffer states is deeply rooted in Geopolitics, which emerged as a field to assess the influence of geographical factors on the human realm of politics. It is evident that the early formulation of the buffer state concept is Geopolitical in nature, given the emphasis on its spatial importance. While geography played a key role in state strategy, ${ }^{20}$ the classical conceptualization of the buffer state's utility as a geographical discontinuity or an "early warning system" evolved with changes in technological advent. The technological innovation and military advent in the aftermath of the First World War greatly depreciated the strategic value of geographic distance. ${ }^{21}$ As a

\footnotetext{
${ }^{19}$ Nayef R.F. Al-Rodhan, Neo-statecraft and Meta-geopolitics: Reconciliation of Power, Interests, and Justice in the $21^{\text {st }}$ Century (Zurich, Switzerland: Lit Verlag, 2009): 45.

${ }^{20}$ It continues to do so but in a different form. While spatial distance does figure as an important aspect of military strategy, it does not hold the same importance as it did before the advent of planes and motorized weapons systems. In the contemporary era, geography remains innate to security strategy, as showcased by the importance played by Pakistan during the military endeavors into Afghanistan in 2001.

${ }^{21}$ Nicholas J. Spykman, "Geography and Foreign Policy, I,” The American Political Science Review 32, no. 1 (1938): 33; Rothstein, Alliances and Small Powers, 20; Al-Rodhan, Neo-statecraft and Metageopolitics, 45; Gray, War, Peace, and International Relations, p.322; Spykman discusses the depreciation of geographic distance as a strategic tool due to technological innovation in the context of all states in the international system, while Rothstein discusses it within the context of small states.
} 
result, the relevance of buffer states should have diminished with such a change in strategic culture, as their utility is tied to their geographical disposition. Yet, some buffer states continue to maintain relevance through the interaction of larger rivalrous states and their crucial role in the dynamics of regional stability. This phenomenon with buffer states calls for a deeper exploration of why buffer states remain relevant in the interaction of regional rivals despite the decline of strategic utility of spatial distance. Thus, the question emerges: why do buffer states maintain relevance despite strides in military technology? What role do they fulfill in contemporary regional/sub-systemic security systems? Given the limited literature on buffer states and lack of any extensive extrapolation on how sub-systemic changes affect the role of buffer states, the proposed study seeks to delve into how subsystemic rivalrous interactions provide continued relevance to buffer states as important aspects of regional power dynamics. This dissertation seeks to add to the study of buffer states but within the context of sub-systemic changes of power dynamics. It seeks to assess the role of modern buffer states and add to the very limited literature related to such states in the international system.

This dissertation provides an explanation for the relevance of buffer states in contemporary International Relations, particularly through the lens of intensification of rivalry between regional powers. It addresses and analyzes the externalization of such subsystemic rivalry in the buffer states. Furthermore, this dissertation seeks to explain the evolving role of buffer states, away from a narrow geographic definition to one where such states have emerged as political spaces for interactions of the more powerful states they separate. It proposes that the continued relevance of the buffer state is a function of power politics at the regional level which play an important role in the patterns of regional stability 
and instability. This dissertation also seeks to add to the limited literature on the buffer state concept, further expanding academic endeavors related to small states in the international system.

\section{Statement of Purpose}

The objective of the proposed dissertation is to premise buffer states within subsystemic analysis in International Relations, by analyzing how and why such states are relevant in regional security. The novelty of this approach rests on connecting the concept of the buffer state to sub-systemic levels of analysis in International Relations. Additionally, this research seeks to contextualize buffer states in contemporary International Relations literature, given that the concept has been largely bereft from academic attention. From a purely geopolitical concept, the buffer state remained an important aspect of statecraft until the First World War; but with technological innovation, the absolute geographical function of the buffer state in strategy of the larger powers eroded..$^{22}$ Rather than becoming obsolete, buffer states maintain relevance in contemporary regional security, a fact that can be attributed to sub-systemic changes in power capabilities and the extensive prevalence of "soft-balancing" in the post-Cold War period. ${ }^{23}$ Thus, this

22 Trygve Mathisen, The Functions of Small States in the Strategies of the Great Powers (Oslo, Norway: Universitetsforlaget, 1972), 126 - While technology has depreciated the utility of buffer states, vicinal geographic position retains its political function. Vicinal geography, as defined by Mathisen, is the contiguity of political borders, which remains an integral part of the international system. Technological progress, particularly in the military realm, reduced the importance of buffer states for their functions as added space in military maneuvering but they maintain relevance for the buffered states. This relevance is tied to the geographic contiguity of the buffer to the buffered states.

${ }^{23}$ Robert A. Pape, "Soft Balancing Against the United States," International Security 30, no. 1 (2005): 7-45;

Pape writes about soft-balancing in the context of American preponderance in the post-Cold War international system. He argues that since directly challenging US military preponderance is impossible or 
proposed study seeks to connect sub-systemic power dynamics to the evolving role of buffer states. It explains why buffer states maintain strategic importance despite the erosion of utility of geopolitical space.

The rationale for this proposed study is to provide a contemporary context for the relevance of the buffer state as an analytical tool in International Relations. As regional or sub-systemic approaches to security become more extensive within the field, an extrapolation on the study of buffer states helps provide a more comprehensive explanation of regional rivalries. Furthermore, it adds to the limited attention that is paid to the relevance of small states within the interactions of the Middle and Great Powers and provides a perspective that has long been in the periphery of the discipline of International Relations. Lastly, the purpose of this dissertation is to use the buffer state framework to assess the trilateral relationship between India, Nepal, and China (the case study for the dissertation), as a function of the rise of India and China. Lastly, this dissertation is an endeavor to create an analytical framework that can be used to assess other buffer systems.

just too costly, states will seek indirect and indirect means to delay, frustrate, and undermine aggressive unilateral U.S. military policies. While this concept may not directly be related to buffer states, the indirect usage of tools outside of military means is definitely relevant for buffer states, as such states are prone to push and pull factors emanating from the larger powers it separates. Additionally, military means are risky in buffer systems due to regional pressures and geographic proximity to the cores of the states involved. 


\section{Significance of Study}

The aim of this dissertation is to contextualize the buffer state concept in contemporary International Relations and explain why it is still a useful analytical tool. Linking buffer states to sub-systemic/regional political dynamics, the study seeks to explain the implications of changes in power dynamics at the regional level to smaller states in the region. Secondly, the dissertation adds to the limited literature on buffer states in the field of International Relations, lending importance to the notion that smaller states need to be included in the analysis of the Great Powers. ${ }^{24}$ It also seeks to add to the sparse literature on buffer states and the dynamics of small states in the international system. Through the specific case study of the triadic relations between India, Nepal, and China, the dissertation also provides analysis on Sino-Indian ${ }^{25}$ relations and how these relations externalize in geographically contiguous states, vis-à-vis Nepal, which maintains a precarious disposition between its neighbors.

The dissertation proposes a novel approach in understanding the contemporary analytical utility of the buffer state concept. The approach is based on tying the concept of the buffer state to sub-systemic/regional dynamics of power, proposing that buffer states maintain relevance and centrality through their evolving roles in regional power politics. While their classical geopolitical utility may have waned due to technological innovation, buffer states still maintain relevance as spaces of political interactions for larger rivalrous

\footnotetext{
${ }^{24}$ Martin J. Bayly, “Imperial Ontological (In)security: 'Buffer States', International Relations and the Case of Anglo-Afghan Relations, 1808-1878," European Journal of International Relations 21, no. 4 (2015): 817.

${ }^{25}$ Sino-Indian is chosen over Indo-Chinese to prevent confusion with the colonial name of Southeast Asia, Indochina.
} 
powers. In sum, the contribution of this dissertation is twofold: first, it rescues the buffer state concept and recasts it in a new significant dimension for the study of international relations. Second, it advances an argument that sheds new light on why and how regional, sub-systemic rivalries simultaneously affect and are affected by the political dynamic and space within small buffer states. Specifically, this study promises to be the first study in the International Relations discipline that focuses on Nepal as an exemplar of the refined notion of the small buffer state, and how the Sino-Indian regional rivalry affects and is affected simultaneously by the dynamic in Nepal's geopolitical space.

\section{$\underline{\text { Research Question \& Hypothesis }}$}

The primary geographic utility of buffer states, focused on spatial discontinuity, has been eroded with the innovation of technology in weaponry, transportation, and communication. ${ }^{26}$ Nevertheless, buffer states still maintain relevance in international relations, particularly in regional security and stability. The geographic utility refers to the spatial utility of buffer states in classical Geopolitics, which emphasizes the strategic importance of distance and space. The shift away from such a conception of buffer states warrants a shift in their conceptual utility, focused on a more politically dynamic concept that helps in explaining cycles of regional stability/instability. Herein lies the opportunity to explain the buffer state's relevance in regional stability in the contemporary context. The buffer state retains an important dynamic in Great Power interactions, as it provides a

\footnotetext{
${ }^{26}$ Chay and Ross, "Introduction," in Buffer States in World Politics, 3.
} 
political space for the externalization of the rivalry of the bigger states. Thus, this project addresses the following research question:

RQ: Why and how are buffer states relevant in sub-systemic rivalries despite erosion of their geographic function?

Based on the premising of the buffer states within regional patterns of security, the hypothesis for the dissertation is as follows:

H1: If sub-systemic rivalries among Middle or Great powers envelop a small, buffer state, then this rivalry will recover the buffer state's political relevance beyond a simple geographical discontinuity among rivalrous powers.

In accordance with the above hypothesis, the independent and dependent variables are as follows.

Independent Variable (IV): Sub-systemic rivalry between middle or great powers Dependent Variable (DV): The buffer state's political relevance beyond just a geographical discontinuity 
Thus, the higher or lower the sub-systemic rivalry between the buffered states, ${ }^{27}$ then the greater or lesser will be the political as well as strategic relevance of the buffer state. The implication for the concept of the buffer state is that its role conception extends beyond just a geographic concept; that the buffer can have increased or decreased relevance in accordance with the power dynamics of the larger powers it separates. Relevance is measured by increased or decreased engagement of the buffered states in the buffer state i.e. increase or decrease in the measures of material and rhetorical engagement. Additionally, the buffer state also fulfills a more strategic role for the externalization of inter-Middle or Great Power rivalry over an overwhelmingly geographically focused role for which the concept was created. Figure 1 showcases the buffer system, which consists of the buffer state and its neighboring buffered states. Figure 2 provides a pictorial depiction of the hypothesis.

${ }^{27}$ Buffered states are countries that are geopolitically separated by the buffer state; if state B is the buffer between two rival powers $\mathrm{X}$ and $\mathrm{Y}$, then $\mathrm{X}$ and $\mathrm{Y}$ are the buffered states separated by buffer state $\mathrm{B}$. 
Figure 1: A Buffer System within a Sub-system

Sub-system

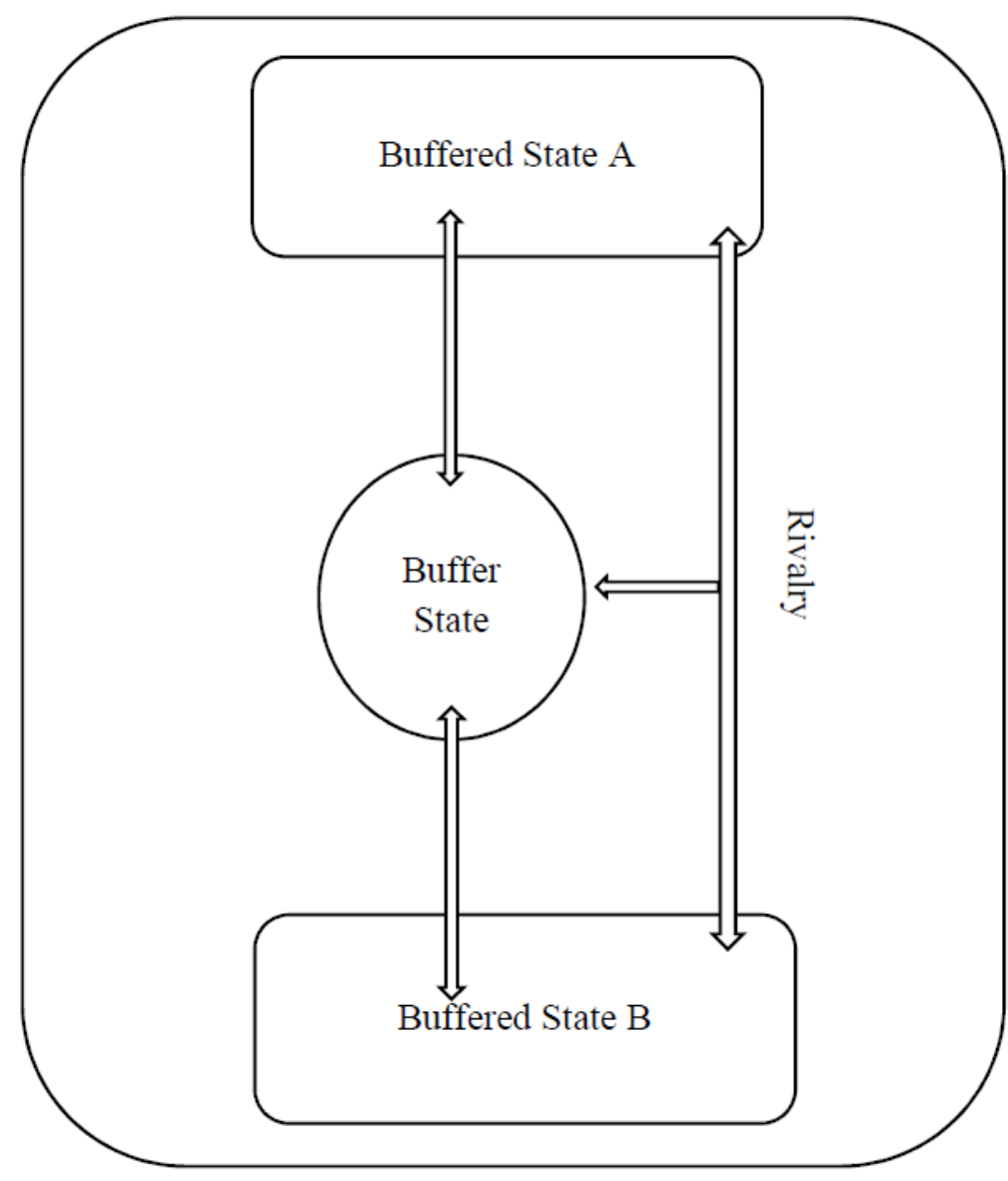


Figure 2: Pictorial Depiction of the Hypothesis
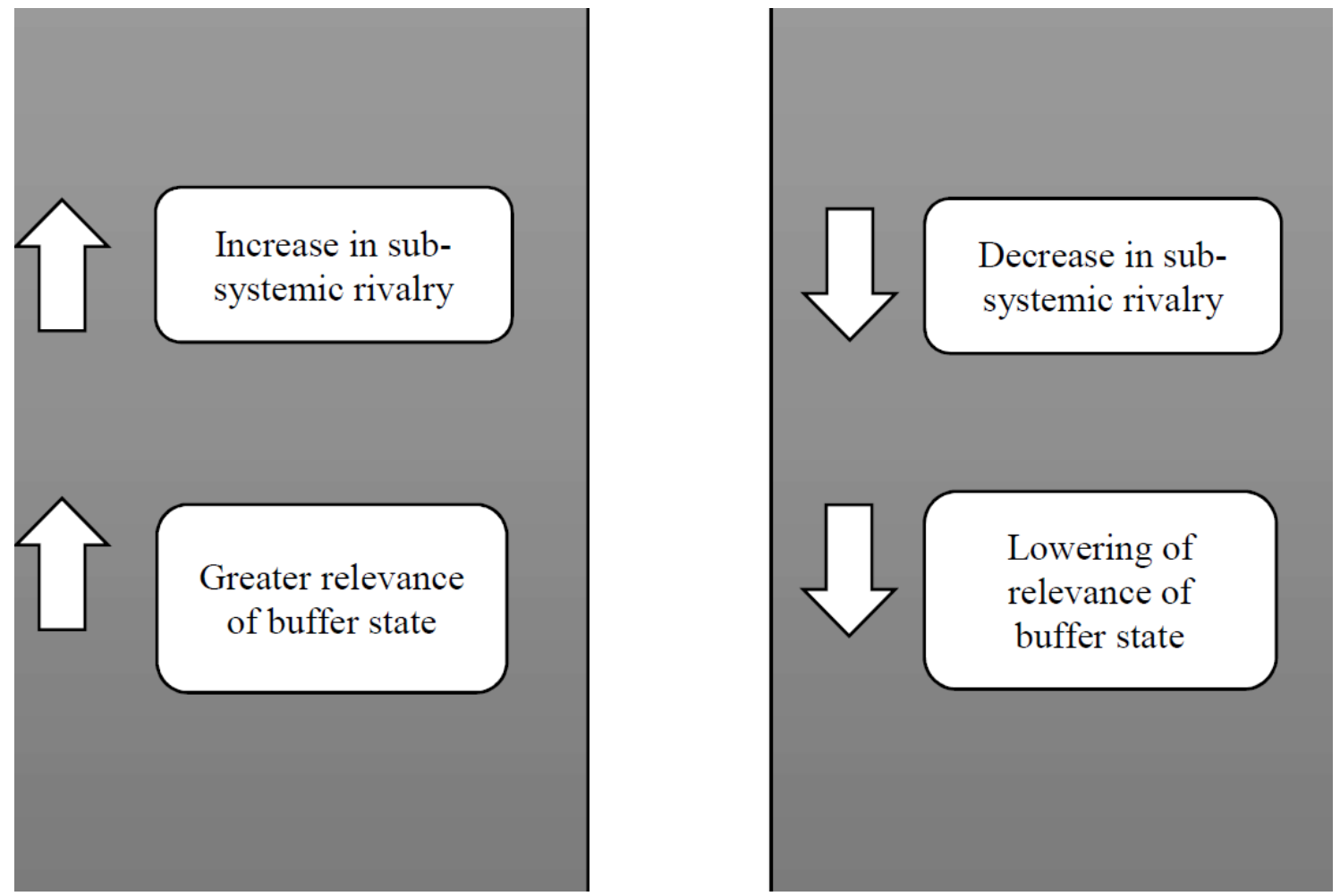

\section{Organization of the Dissertation}

The dissertation includes seven chapters. Chapter I introduces the premising of the buffer state literature within the field of International Relations. It includes the research question, hypothesis, and the significance of the study. The aim of Chapter II is to introduce the literature review on the buffer state concept. Given that buffer states are overwhelmingly small states, this chapter initially examines the existing literature on various theoretical perspectives on small states. Then the chapter moves on to examine the literature on buffer states, including the conceptualization of Nepal as a buffer state. Since the buffer state is innately tied to geopolitics, literature on rivalry and geographic contiguity are also discussed; the ending of this chapter covers contemporary work on the buffer state 
that discusses its relevance. Since the dissertation seeks to tie the buffer state to its subsystemic predicament, academic works on the emergence of sub-systemic approaches to security studies are discussed throughout Chapter II.

Chapter III discusses the mixed method research design chosen for the dissertation and the methodologies used to gather both qualitative and quantitative data. The qualification of the case study used for the study i.e. the triadic relationship between India, China, and Nepal is justified in this chapter. It also includes how the chosen case study fits the pursuit of an explanation for the research question of the dissertation. The chapter also discusses how the analyses for qualitative and quantitative data are carried out.

Chapter IV describes and explains the critical junctures in the India-Nepal-China buffer system (INCBS) which have implications for the sub-systemic dynamics between India and China, including the implications that may have been explained by the buffer state Nepal. In this chapter, each critical juncture is carefully extrapolated and contextualized on the central theme of buffer states in sub-systemic rivalries. Thus, these critical junctures are carefully chosen to analyze the pre-, during, and post- intensity of sub-systemic rivalry between India and China in Nepal.

Chapter $\mathrm{V}$ covers the conduct of qualitative and quantitative data analyses, reporting of their results and the organized presentation of the analyses results. The organization of the qualitative and quantitative data analyses for the convergent parallel design of the proposed study is included in this chapter. The organization of the results of the analyses is in preparation for the process of convergence/divergence and collective interpretation, which are covered in Chapter VI. 
Chapter VI is focused on the collective comparison and interpretation of the results of the analyses carried out in Chapter V within the larger framework of the buffer state literature. The chapter compares the results of the two analyses. Then, the chapter covers the amalgamation of the qualitative and quantitative analyses to decipher whether there is convergence or divergence in the results of the quantitative and qualitative analyses. Lastly, the data analyses are interpreted collectively.

Finally, Chapter VII includes the conclusion of the dissertation, which explains the ties between the buffer state and the sub-systemic power dynamics through the detailed analysis of the case study chosen. This chapters revisits the hypotheses of the dissertation and accepts or rejects them based on the results of the data analyses. In essence, the conclusion seeks to formulate theoretical implications of the study and how it adds to the existing literature on buffer states and their relevance to International Relations through changes in sub-systemic power dynamics. 


\section{CHAPTER II: LITERATURE REVIEW}

Chapter II delves into existing theoretical as well as empirical works relevant to the dissertation. Firstly, this chapter surveys existing literature on small states, given the need to premise such states within the larger field of International Relations that extensively concerns Great Power politics. Next, the literature on buffer states is reviewed as a sub-set within the category of small states. It is followed by the literature on geographic contiguity and its implications for the security dynamics of Middle or Great Powers. Given the strongly geopolitical root of buffer states and their vital role in maintaining regional stability, it is instrumental in deciphering how the buffer concept fits within the literature on rivalry and geographic contiguity. Finally, the literature on the continued relevance and utility of the buffer state concept in International Relations is explored. It ties in the question on why and how buffer states continue to be relevant in regional patterns of contemporary security dynamics despite extensive constraining of the utility of geopolitical space due to advances in military technology.

\section{$\underline{\text { On Small States }}$}

The literature on small states is pertinent to this dissertation, as most buffer states tend to be small states in the international system. But it is also essential to note that not all buffer states are small states. The issue of this line of thinking, however, rests on defining what a small state is. Since there is no consensus on the definition of small states, it is a 
highly contested concept in both theory and practice. ${ }^{28}$ While the contemporary system of states accords legal equality to all states, big and small, there is inherent inequality of other forms that are expressed formally and informally in international affairs. While small states were largely sidelined in academic endeavors in International Relations, there has been increasing attention on such states after the end of the Cold War. The conclusion of the bipolar split based on ideology created political space for many small states to pursue foreign policies without many of the Cold War's systemic constrains.

David Vital's preliminary definition of small powers rests on measures such as population, ${ }^{29}$ which authors like William E. Paterson and Robert Keohane criticize as cursory and lacking analytical depth. ${ }^{30}$ Vital's usage of population as a marker for small powers runs the problem of lumping states like Sweden and Rwanda in the same category, while remaining ambiguous towards larger underdeveloped states with significant populations but limited power capabilities.

Vital revises his definition in his later work titled The Survival of Small States (1971) by describing a small power as:

${ }^{28}$ Baldur Thorhallsson and Anders Wivel, "Small States in the European Union : What Do We Know and What Would We Like to Know ?" 19, no. 4 (2006): p.652.

${ }^{29}$ David Vital, The Inequality of States: A Study of the Small Power in International Relations (Oxford, UK: Clarendon Press, 1967), 7-8- Vital defines small powers as those states with an upper limit of population of 10-15 million if economically advanced or a population of 20-30 million for an underdeveloped country. (1969):119;

${ }^{30}$ William E. Paterson, "Small States in International Politics," Cooperation and Conflict 4, no.1

Robert O. Keohane, "Lilliputians' Dilemmas: Small States in International Politics," International Organization 23, no.2 (1969): 294. 
"that state which, in the long term, in itself and as a satellite or client or close ally - i.e. as a non-autonomous participant in international politicscan constitute more than a dispensable and non-decisive increment to a primary state's total array of political and military resources, regardless of whatever short-term, contingent weight as an auxiliary (or obstacle) to the primary power it may have in certain circumstances. ${ }^{\prime 31}$

In other words, Vital proposes a definition that is not contingent to population size; in fact, he presents an approach that is more nuanced and tied to the dynamic nature of small states in the international system.

Another perspective on small states rests on their alliance formation; specifically, Robert Rothstein ties the role of small states to balance of power. He defines small states as those states that cannot obtain security through their own capabilities. ${ }^{32}$ Such states attain security through alliance formation with larger powers. But then again, this definition does not accurately depict the various types of states that exist in the international system; there is also the possibility of bifurcating the states of the world into Great Powers - states capable of attaining security, and the other states - all non-Great Powers that have the potential to face insecurity emanating from the Great Powers. Keohane rightly raises the concern that Great Powers too could face security threats despite being materially capable. He proposes an approach based on systemic roles, categorizing states into the following:

${ }^{31}$ David Vital, The Survival of Small States (London, UK: Oxford University Press, 1971), 9 - Vital describes tertiary powers as those states with miniscule impact on the international system.

${ }^{32}$ Rothstein, Alliances and Small Powers, 29. 
i System-determining: States that are considered superpowers and can act unilaterally without major threats to their own security,

ii System-influencing: States that can impact the system through multinational organizations,

iii System-affecting: States that can influence the system through alliance formations and regional organizations, and

iv System ineffectual: States that have minimal impact on the system or are dominated by larger powers. ${ }^{33}$

Despite the lack of systemic influence, small states can play key roles at the subsystemic levels. Since small states exert limited international influence, their interests tend to be limited as well. Given this reality, their international relations are concerned with sub-systemic security dynamics. ${ }^{34}$ This holds true for buffer states as well, as they tend to be mostly concerned with the security relations of the buffered states rather than systemic level politics. This is largely due to their limited material capabilities and immediate importance placed on relations with geographically contiguous neighbors. Raimo Vayrynen focuses on this approach; he proposes another definition of small power:

\footnotetext{
${ }^{33}$ Keohane, “Lilliputians’ Dilemmas,” 295-296.

${ }^{34}$ Paterson, "Small States in International Politics," 122.
} 
"A small power is a state which has a low objective and/or a low perceived rank in the context where it is acting. Furthermore, small powers are expected to behave in a given way, i.e. their role prescriptions differ from those of middle and great powers, which affect together with their low rank upon their behavior and possibilities of influence. Finally, the interests of small powers are at least to some extent different from the interests of great powers, a fact which denotes the latent or manifest conflict of interests between these two classes of states." 35

Vayrynen's approach is based on a multi-faceted analysis of what constitutes a small power. Regardless, none of the authors provide a rigorous analysis of buffer states. They set the premise for small states, which most buffer states are but the distinct nature of a buffer state's disposition between two rivalrous rival powers makes it a unique type of small state. Keohane does raise important points on the systemic role of the small states and how that impacts their behavior as well as strategies. But he does not use this conception to further the behavior of buffer states or how they fit into regional patterns of security and insecurity.

Veenendaal and Corbett (2015) showcase the biases against small states in the subfield of Comparative Politics. Although not directly related to the buffer state system, their argument highlights the biases against small states in the academic setting. They put forth

${ }^{35}$ Raimo Vayrynen, “On the Definition and Measurement of Small Power Status," Cooperation and Conflict 6, no.1 (1971): 99. 
a list of explanations on why small states are largely left out of major academic endeavors in Comparative Politics:

“1. small states represent only a tiny proportion of the world's population (e.g., Huntington, 1991; Moore, 1995);

2. small states are not "real" or fully independent states (e.g., Vanhanen, 1997);

3. other authors in this academic field exclude small states as well (e.g., LeDuc, Niemi, \& Norris, 2002; Lijphart, 1999);

4. there is a structural lack of data on small states (e.g., Powell, 1984; Vanhanen, 1997); and

5. the principle of "most similar" comparison is more appropriate in some circumstances (e.g., Rhodes, Wanna, \& Weller, 2009, p. 11)."36

The argument made by Veenendaal and Corbett not only showcases the need for deeper extrapolation on the role of small states but also the academic biases that may prevent a complete explanation of political dynamics occurring in the international system. More academic attention to small states does not entail less importance to larger powers; rather, the argument is that greater analytical attention to small states would facilitate a more complete understanding of politics of the larger powers. Further academic attention to small states would be beneficial not only for Comparative Politics but also for International Relations; study of small states contributes in covering more case studies and

${ }^{36}$ Wouter P. Veenendaal and Jack Corbett, "Why Small States Offer Important Answers to Large Questions," Comparative Political Studies 48, no. 4 (2015): 530 
may lend more validity to theorizing within Comparative Politics and International Relations. While these authors do not directly contribute to the literature on buffer states, they make a crucial point regarding the need to conduct more research on small states.

While small states have been traditionally sidelined by mainstream studies in Political Science and International Relations, the trend is changing. There is an increased interest in the study of small states, particularly related to their security. ${ }^{37}$ Even within the sub-field of security studies, there is a lack of a consistent and comprehensive approach to security related academic endeavors in the study of small states. ${ }^{38}$ Archer et al. seek to do just that; they offer a comprehensive approach to understanding the security challenges and opportunities of small states in the contemporary international system. Their work runs into the same issue as others: how to define a small state. They settle on material power capabilities as the parameter to define to small states. Their case is supported by three benefits:

"First, if we are to analyse the opportunities, challenges and limitations of a specific state, indications of absolute and relative capacity are important, because they inform us of the absolute and relative limitations on these states' capacity to handle different types of challenges. Second, an absolute and universal threshold between big and small states of, for example, a population size of 15 million people, or a GDP of $€ 500$ billion, has the

${ }^{37}$ Anders Wivel, Alyson J.K. Bailes, and Clive Archer, "Setting the Scene: Small States and International Security," in Small States and International Security, eds. Clive Archer, Alyson J.K. Bailes, and Anders Wivel (New York, NY: Routledge, 2014), 4.

${ }^{38}$ Kassimeris, "The Foreign Policy of Small Powers," 84; Anders Wivel, "Setting the Scene," 5. 
benefit of creating a clear and easily applicable definition of small states....Third, starting from a power possession definition allows us to draw on the comprehensive literature on power and security in international relations in order to identify why, when and how the security challenges of small states are distinct from those faced by stronger states. ${ }^{\prime 39}$

Archer et al.'s characterization touches upon the novel idea of state limitations as a means of assessing its smallness. They add nuance to their definition of small states by including the relational dimension and asymmetry. Adding to this line of thinking, Thorhallsson and Wivel (2006) argue that a state's smallness is not just a matter of material capabilities; it also depends on soft power and the understandings of foreign policy elites and the public of the proper role of the state in global and regional affairs. ${ }^{40}$ As such, the definition of a small state is a matter of the relational dimension and role conception of elites rather than being purely based on material capabilities.

As for the asymmetric approach, a small state is defined as the weaker actor in such a power relationship. ${ }^{41}$ Asymmetric relationships are characterized by a substantial power differential between the two actors involved, hence the name. Given its weaker status in the dyadic relationship, the small state is unable to change the nature or

\footnotetext{
${ }^{39}$ Wivel, "Setting the Scene," 6-7.

${ }^{40}$ Thorhallsson and Wivel, "Small States in the European Union," 664-65.

${ }^{41}$ Wivel, "Setting the Scene," 9.
} 
functioning of its relations with the larger power on its own..$^{42}$ This dyadic approach to assessing smallness of a state is highly subjective and may not always be useful for overarching arguments. For instance, a Middle Power would be designated as a small power if it is in a dyadic relationship with a Great Power, which is not accurate in the depiction of the nature of the Middle Power. Nevertheless, it adds nuance to the traditionally broad reaching conceptions of what constitutes a small state.

While small states have traditionally been academically sidelined, there is an emerging body of literature that examines the role of such states in contemporary international politics. The small states of the European Union have garnered the most attention, especially after the end of the Cold War; ${ }^{43}$ work on non-western small states continues to remain scarce but growing. ${ }^{44}$ The new wave of small state authors emphasize the agency of such actors, going beyond their conceptualization as disposable players in the international system. Gibert and Grzelczyk (2017) critique the overall academic endeavors on small states for portraying them as passive participants; they argue that "small

\footnotetext{
${ }^{42}$ Caroline Howard Grøn and Anders Wivel, "Maximizing Influence in the European Union after the Lisbon Treaty: From Small State Policy to Smart State Strategy Maximizing Influence in the European Union after the Lisbon Treaty," Jounal of European Integration 33, no. 5 (2011): 524; Hans Mouritzen and Anders Wivel, "Introduction" in The Geopolitics of Euro-Atlantic Integration, eds. Hans Mouritzen and Anders Wivel (Oxon, OC: Routledge, 2005): 4.

${ }^{43}$ Examples of such works include but are not limited to the following: Caroline Howard Grøn \& Anders Wivel (2011) Maximizing Influence in the European Union after the Lisbon Treaty: From Small State Policy to Smart State Strategy, Journal of European Integration, 33:5, 523-539; Jean-Marc Rickli, "European small states' military policies after the Cold War: from territorial to niche strategies," Vol 21, no.3 (2008), 307-325; Baldur Thorhallsson and Anders Wivel, "Small States in the European Union: What Do We Know and What Would We Like to Know?" Cambridge Review of International Affairs, Vol. 19, no.4 (2006), 651 668; Anders Wivel (2005), "The Security Challenge of Small EU Member States: Interests, Identity and the Development of the EU as a Security Actor," Journal of Common Market Studies, Vol.43, no.2, 393-412.

${ }^{44}$ Marie V Gibert and Virginie Grzelczyk, "Non-Western Small States : Activists or Survivors ?," Third World Thematics: A TWQ Journal 1, no. 1 (2017): 1-2.
} 
states have often been considered as interesting only in their relations within an institutional setting they could contribute to, or receive advantages from, or in how they would attempt to avoid collapse and disappearance, being absorbed by a larger state." ${ }^{\prime 5}$ The authors infer to the focus on small state voting behavior in the United Nations, without much attention being paid to the motivations and interests of such states in the international system, outside of institutional frameworks of intergovernmental organizations.

Kassimeris (2009) makes a similar case by arguing that small powers do not lack power per se; what they lack is the opportunity to display it. ${ }^{46}$ Small states are not studied for their agency; rather, they are largely included in academic discourse that focus on larger powers - the crux of most of the studies is on how small states fit as minor players or mere additions to Great Power politics. The end of the Cold War heralded a new era for the study of small states; it opened up the international political space for more dynamic small power interactions. Thus, there are emerging calls for greater look at the agency of small states in international politics as the systemic constrains of the Cold War were lifted.

There is also a push to include other regions of the world to garner a more global understanding of the role of small states in international politics. A collection of journal articles published by Third World Thematics: A TWQ Journal makes a fresh push for the study of small states outside of the West. Titled "Non-Western Small States," the special issue opens a new avenue for the study of small states, which were traditionally marginalized. Bailes et al. (2017) make the case that small states are inherently different;

\footnotetext{
${ }^{45}$ Gibert and Grzelczyk, "Non-Western Small States," 1-2.

${ }^{46}$ Kassimeris, "The Foreign Policy of Small Powers," 85.
} 
using the case studies of Cuba, Armenia, and Singapore, the authors make the case that small state diplomacy is tied to flexibility in their approach to changing power dynamics in the international system and unity of action in the domestic realm. ${ }^{47}$ They further critique Alliance Theory for not incorporating the differentiated behavior of small states; instead, they propose Alliance Shelter Theory. This Theory is based on the idea that the functional logic of small states is different; these states seek shelter from larger states and for this, they emphasize international cooperation. ${ }^{48}$

Gigleux (2017) uses role theory to analyze small state behavior. He argues that small states have multiple self-understandings which are shaped by the perceptions, demands, and expectations of other actors in the system. ${ }^{49}$ Role theory suggests that the international policies of small states are largely reflective of national identity. In another work, David Styan uses the case study of Djibouti to analyze its strategies as a small state. He takes issue with the Alliance Shelter Theory and argues that his case study, Djibouti, has not adopted policies that reflect the 'safety in numbers' approach propagated by the theory. ${ }^{50}$ Rather, Djibouti has maintained cordial relations with its much larger neighbor, Ethiopia, which in return relies heavily on its smaller neighbor for access to oceanic trade

${ }^{47}$ Alyson J K Bailes, Bradley A Thayer, and Baldur Thorhallsson, "Alliance Theory and Alliance 'Shelter ': The Complexities of Small State Alliance Behaviour Small State Alliance Behaviour," Third World Thematics: A TWQ Journal 1, no. 1 (2017): 21.

${ }^{48}$ Ibid., 13.

${ }^{49}$ Victor Gigleux, "Explaining the Diversity of Small States' Foreign Policies through Role Theory," Third World Thematics: A TWQ Journal 1, no. 1 (2017): 39.

${ }^{50}$ David Styan, "Djibouti : Small State Strategy at a Crossroads Djibouti : Small State Strategy at a Crossroads," Third World Thematics: A TWQ Journal 1, no. 1 (2017): 80. 
lanes. It also showcases no desire to become part of a coalition of small states, as inferred by the Alliance Shelter Theory.

Other works on non-western small states include that of Kadira Pethiyagoda. He makes the case for Sri Lanka's importance to China, the US, and India, given its strategic location in the busy Indian Ocean sea lanes. His write-up argues that small states are capable of alliance formations with regional or global powers i.e. changing international political dynamics or as the author points, the emerging multipolar world has widened the room for smaller states to diversify their partnerships. ${ }^{51}$ Pethiyagoda adds that, "In the future, small states, particularly with strategic relevance like those around the Indian Ocean and the Middle East, will have more options to switch between multiple poles. Great powers will have less leverage.” ${ }^{52}$ Pethiyagoda's argument rests on Sri Lanka's case, where he highlights the transition from a pro-China government under Mahinda Rajapaksa to a more pro-US and pro-India government of Mathila Sirisena. His argument is a novel perspective in the post-Cold War period and has implications for the study of small states. He does not simply assume the small state (in this case, Sri Lanka) as merely an extension of Great Power interactions; rather, Sri Lanka is studied as an actor with agency, capable of making decisions that have ramifications for Great Powers.

While Pethyagoda touches on the increasing agency of small states in international politics, Tom Long (2017) creates an analytical framework for assessing the agency of

\footnotetext{
${ }^{51}$ Kadira Pethiyagoda, "Order from Chaos: Why Small States matter in International Politics: The Case of Sri Lanka," The Brookings Institution, last modified September 3, 2015, https://www.brookings.edu/blog/order-from-chaos/2015/09/03/why-small-states-matter-in-internationalpolitics-the-case-of-sri-lanka/.

${ }^{52}$ Pethiyagoda, "Order from Chaos."
} 
small states. His argument is that small states do not have the means to exercise power in the same manner as Great Powers. Given this impediment, small states use nonconventional means wherein military force becomes less acceptable; instead, there is greater emphasis on interdependence, norms, and institutions. ${ }^{53}$ While Gibert and Grzelczyk (2017) criticized the limits of studying small states within institutional frameworks, Long conceptualizes such behavior as an expression of the small states' agency, which is extremely limited outside of institutional frameworks that are guided by interdependence and norms.

Experts of small states, including the likes of David Vital, Robert Rothstein and Niels Amstrup, have all presented contending analytical structures to classify and understand such states. Since the end of the Cold War, there has been an inherent push to study small states. While much of the literature on such states is focused on those that belong to the European Union, work on non-Western small states have garnered some attention. The likes of Kassimeris, Bailes et al., Gigleux, and Pethiyagoda have put forth novel means of assessing non-Western powers in the international system. But none of these endeavors provide any detailed account on the behavior and analytical utility of buffer states. While 'small state' as the object of study has garnered some traction within academic circles, the attention to buffer states remains scant. Nevertheless, there is a very small group of academics who have written on the subject, including relatively novel approaches to assessing the role of buffer states. These works are extrapolated in the following section.

53 Tom Long, "Small States, Great Power? Gaining Influence Through Intrinsic, Derivative, and Collective Power," International Studies Review 19, no. October (2017): 200. 


\section{On Buffer States}

Any discussion on buffer states needs to address its roots in Geopolitics ${ }^{54}$ given that its political meaning is derived from its geographic disposition. Geopolitics developed as a novel discipline in Europe just before World War I. Deliberations over the political utility of studying geography led to the development of the field. In its early stages, Geopolitics sought to make sense of the influence of geography on the human political realm. The erstwhile focus of the discipline of Geography on the physical topography of the Earth was reaching its limit of utility. Also, geography was increasingly seen as an innate aspect of human civilization. Friedrich Ratzel, the pioneer thinker in Geopolitics, attempted to bridge the gap between pure geography ${ }^{55}$ and history. Translation of Ratzel's work from German to English by Ellen Churchill Semple was the first analytical attempt at linking what was until then two disparate disciplines. In Ratzel's own words, "the national history of any state is influenced by local climate, soil, rivers, and boundaries of mountains or deserts."56 Thus, he deemed it necessary to include human interactions amongst themselves and with nature when studying geography. Early geopolitical writings such as Ratzel's and Semple's argued for a causal linkage that promoted a deterministic view of geography; they argued that human interactions, including innovation and culture, were shaped by the topography

\footnotetext{
54 The names Geopolitics and Geography as opposed to geography and geopolitics refer to the names of the respective disciplines.

${ }^{55}$ Pure geography dealt with just the physical topography of the earth, with little connections made with the realm of human civilization.

${ }^{56}$ Ellen Churchill Semple, Influences of Geographic Environment on the Basis of Ratzel's System of Anthropo-Geography (New York, NY: Henry Holt and Company, 1911), 4.
} 
that they resided in. ${ }^{57}$ This deterministic approach has long been criticized for being too simplistic and narrowly conceptualized. Nevertheless, it cannot be discounted that Ratzel pioneered a new avenue for analyzing state behavior - one that considered geography as an important aspect of statecraft, which had immense implications for the study of buffer states. Thus, the discipline of Geopolitics emerged to analyze how geography influences state policy i.e. how a state's geographic disposition impacts its role conceptualization and the subsequent policies that it adopts as part of its statecraft. It formalized the study of geography and its links to the political realm of human civilization.

Other classical geopolitical writers, including Halford Mackinder, Robert StrauszHupe and Richard Spykman further pursued the linkages between geography and foreign policy of states. Given that the very existence and purpose of the buffer state is defined by its geographic disposition between larger powers, this linkage between geography and foreign policy remains of utmost importance for its study. Mackinder's Heartland Theory provided strategists with a unique means of assessing political strategy; an approach that emphasized the control of the Eurasian Heartland as key to the establishment of a global empire. ${ }^{58}$ Mackinder moved beyond the deterministic linkages between geography and the political realm of humanity; he emphasized a more nuanced approach to the discipline of Geography, one that sought to explain the political behavior of humans. Mackinder revolutionized Geography from a discipline strictly concerned with the topography of the world to one that accounted for how it can be related to humanity; essentially, Mackinder

${ }^{57}$ Semple, Influences of Geographic Environment on the Basis of Ratzel's System of AnthropoGeography, 12.

${ }^{58}$ Harold J. Mackinder, “The Geographical Pivot of History,” The Geographical Journal XXIII, no. 4 (1904): 421-44. 
developed Ratzel's conceptual foundations even further and established Geopolitics as a separate sub-field. Topography no longer remained apolitical as it took on political significance and meaning.

Robert Strausz-Hupe took Mackinder's argument further by not only emphasizing the importance of the Heartland for strategic value but the very importance of living space, which remained an integral part of German Geopolitik and later contributed to the Nazi concept of the Lebensraum. ${ }^{59}$ Thus, the living space as a conception was political as it was geographic; its usage during the Second World War was tragic.

The crucial importance of geographic space for state development had become a quintessential aspect of classical geopolitics but it was Nicholas J. Spykman who directly linked geography with foreign policy making. He argued that geography was one of many factors that determined foreign policy of a state. Spykman adds that:

"topography affects strength because of its influence on unity and internal coherence. Climate, affecting transportation and setting limits to the possibility of agricultural production, conditions the economic structure of the state, and thus, indirectly but unmistakably, foreign policy.", 60

In essence, he undermined the deterministic aspect of geopolitics that dominated the earlier years of the discipline. But not unlike his predecessors in Geopolitics, Spykman

${ }^{59}$ Robert Strausz-Hupe, Geopolitics: The Struggle for Space and Power (New York, NY: Putnam, 1942).

${ }^{60}$ Ibid. 
asserts that topography does influence economic relations and subsequently, the political structure and foreign policy-making of states. Geographic layout has implications for state development and its overall capacity to transform its material potential to capability. Spkyman modified classical Geopolitics from a purely deterministic discipline to a more complex and multilayered approach in understanding the links between geography and politics. Geographic difficulty was gradually overcome due to technological innovation, but topography could not be ruled out of politics. Geographic location played an important role in strategy of states and it was especially important for dispersion of technology, which would in turn lead to increased overcoming of geographic remoteness.

Discussing buffer states requires acknowledgment of the fact that the concept is an ancient form of state strategy, particularly used by Empires or other forms of Great Powers. The political strategy of using buffer zones as cushions for the political core from external threats, such as barbarians and other major powers, can be traced back to the era of the Roman Empire. Utilizing march states ${ }^{61}$ and wastelands to demarcate and secure their boundaries, the Romans were one of the earliest to deploy the concept of buffer zones. ${ }^{62}$ In the Middle Ages, Britain and Germany used this concept in the form of march lords, who controlled the march states but had time and again successfully asserted their own independence. ${ }^{63}$ In the $10^{\text {th }}$ and $11^{\text {th }}$ centuries, Normans established lordships on the border

${ }^{61}$ Chay and Ross describe march states as peripheral states that served to cushion external threats to the core of the Roman Empire, which included Germanic tribes such as the Goths.

${ }^{62}$ Chay and Ross, "Introduction," in Buffer States in World Politics, 1.

${ }^{63}$ Mary Gear, "Role of Buffer States in International Relations," The Journal of Geography XL, no.3 (1941): 82 . 
between England and Wales; called the marcher-lords, they were independent barons who could wage war, erect castles and hold courts without reference to the crown. ${ }^{64}$ These marcher-lords were responsible for protecting the frontiers of English territory, protecting the core from external attacks. ${ }^{65}$ Thus, the idea of frontier regions in areas of contention is not modern and has a long history rooted in the security strategies of empires. Nevertheless, it must be noted that it was the formalized study of Geopolitics and its eventual development as an analytical framework that allows us to analyze these old strategies from a modern academic lens.

Despite its existence for an elaborate period of human history, the modern day concept and nomenclature of the buffer state as a geographic space separating larger powers or serving as territorial discontinuities between them, was only used in 1876 while the buffer state as a distinct political terminology emerged in $1883 .{ }^{66}$ In the context of the modern international system, the British were the first to employ the concept of the buffer state in Afghanistan to separate British and Russian spheres of influence during the Great Game.$^{67}$ It would not be a stretch to ascertain that the concept of the buffer state emerged out of European geopolitics and was widely employed by Britain throughout its imperial interests, most importantly in the areas around British India, its Crown Jewel. ${ }^{68}$ 1942)

${ }^{64}$ Robert Strausz-Hupe, Geopolitics: The Struggle for Space and Power (New York, NY: Putnam,

65 "Marcher Lords," The Hutchinson Unabridged Encyclopedia with Atlas and Weather Guide (Abington, UK: Helicon, 2016).

${ }^{66}$ Ross, "Buffer States: A Geographer's Perspective," in Buffer States in World Politics, 16.

${ }^{67}$ Fazal, "State Death,” 70; Ross, "Buffer States," 20.

${ }^{68}$ British India was known as the Crown Jewel of the Empire due to its economic and strategic value. As such, its security was of paramount interest to London. 
The deployment of the buffer state concept as a form of state strategy was widespread in the British Empire. Apart from Afghanistan, Britain deployed the concept in Nepal and Tibet as well. It is explicitly demonstrated in rhetoric, both in Nepal and Britain. Nepal's founder, King Prithvi Narayan Shah, in his collection of policies related to Nepali statecraft called the Dibyopadesh (दिव्योपदेश), ${ }^{69}$ highlighted his country to be a "yam sprouting between two huge boulders."70 It is most explicitly implied at the conclusion of the Anglo-Gorkha ${ }^{71}$ (Nepal) War. While the British won the conflict against the Gorkha Empire, ${ }^{72}$ they did not annex its territory "fearing contiguity with Tibet, a Chinese protectorate, which would spark off border clashes." ${ }^{, 73}$ The British attitude towards Nepal is evidence of the deployment of a classical buffer state conception of the latter. As defined by Chay and Ross, buffer states are "countries geographically and/or politically situated between two or more large powers whose function is to maintain peace between the larger powers." ${ }^{, 74}$ British acknowledgement of Chinese sensitivities in Tibet vis-à-vis

${ }^{69}$ Nepali term for "Words of Wisdom."

${ }^{70}$ Daman R. Tuladhar, Contemporary Nepal (1945-1955) (Kathmandu, Nepal: Laxmi Publications, 1980), 11. Accessed at the Ministry of Archaeology, Kathmandu, Nepal on 24 June, 2016.

71 The Kingdom of Gorkha was the erstwhile name of the Kingdom of Nepal; the change in name occurred during the mid- $19^{\text {th }}$ century after the unification of Nepal under the tutelage of the Shah Dynasty. Before the unification of Nepal under the Shah Dynasty, the region consisted of numerous principalities, the most important ones being the confederations of 22 and 24 principalities in the Karnali and Gandaki regions of Nepal; the eastern tribes and the three cities of the Kathmandu Valley;

Krishna Kant Adhikari, "The Status, Powers and Functions of Rajas and Rajautas during the Nineteenth Century Nepal in the Light of Contemporary Documents," Contributions to Nepalese Studies VIII, no. 1 (1980).

72 The Gorkha Empire was later renamed Nepal to reflect the multiethnic nature of the state.

${ }^{73}$ Ravuri Dhanlaxmi, British Attitude to Nepal's Relations with Tibet and China (1814-1914) (Delhi, India: Bahri Publications Private Limited, 1981), 30. Accessed at the British Library, London on $12^{\text {th }}$ August, 2016.

${ }^{74}$ Chay and Ross, "Preface," in Buffer States in World Politics, xiii. 
Nepal showcases the fact that both Tibet and Nepal acted as buffers between the erstwhile Great Powers, Imperial Britain and China. It is Britain's ascertaining of Chinese interests in Tibet that affirms the buffer system between Britain, China and the two smaller powers -- Nepal and Tibet.

British acknowledgment of the independence of the Kingdom of Nepal is another factor that reaffirms its approach to keeping Nepal as an independent buffer state. The central theme of the buffer system rests on the premise that it maintains its independence, even though it is highly susceptible to intrusion from the buffered states. A letter sent on 1 April 1916 by the then Prime Minister of Nepal, Chandra Shamsher Rana, to British Colonel Manners Smith addresses the British commitment to Nepal's independence. Prime Minister Rana, acknowledging British support for Nepali sovereignty, writes the following:

"I am also very thankful for the reiteration of the assurance given in 1911 impressing on us the earnest desire of the Government of India to scrupulously respect the status of Nepal as an independent kingdom. I am no less thankful for the king promise of the sympathetic consideration of any complaints or suggestions we might have to make at any time in that connection and I am very sensible of the friendly spirit which dictated it. As an indication of the cordial feelings which the Government of India entertain towards us, we do certainly value all these quite as much as we do our friendship with them." 75

\footnotetext{
${ }^{75}$ Nepal - Independent Status of, Correspondence from Nepali Prime Minister Chandra Shamsher Rana to Lieutenant-Colonel J. Manners Smith, Resident in Nepal, April 1 1916, File No. 2/1960, British Embassy F.O. 766/2, The National Archives, Kew Gardens, London, UK.
} 
The Government of Nepal under Chandra Shamsher was aware of Britain's preponderance in India and Nepal's vulnerabilities as a small buffer state between much larger powers. As such, the status of Nepal as an independent kingdom was reiterated to ensure its autonomy while also appearing to be in an asymmetric relationship with the British. The Nepal-UK relations largely stemmed from mutual security concerns; while Nepal maintained a semblance of geographic security for British India, the UK was concerned over Russian interests in Tibet and the possible spillover into Nepal - an extension of the Great Game that was taking place in Central Asia. ${ }^{76}$ As for Nepal, it was concerned about the activities of several political outfits operating in India that sought to oust the Rana regime. ${ }^{77}$ Thus, the alliance between Nepal and British India was natural as both states had security concerns that could translate into an opportunity for issue linkage. Despite the asymmetric nature of the relationship, Nepal's buffer status was maintained; Britain's main concern regarding the country was rising Russian interests, coupled with fears for spilling of such threats into Nepal - a country that was geographically contiguous with British India. Thus, British India followed the "forward policy" that integrated the mountain kingdoms of Nepal, Sikkim, and Bhutan into the defense system of the Empire;

\footnotetext{
${ }^{76}$ Madan Kumar Bhattarai, Diplomatic History of Nepal (1901-1929): A Critical Appraisal of Nepal-British-Indian Relations (New Delhi, India: Ashoka Printers, 1990), 8. Accessed at the Ministry of Archaeology, Kathmandu, Nepal on June 10, 2016.

${ }^{77}$ The Rana Regime of Nepal (1846-1950) was the absolute rule of the Rana oligarchs, who reduced the Shah monarchy to mere figureheads. Several political outfits, including the Nepali Congress Party, had initiated armed revolts against the Ranas. Before the departure of the British from India in 1947, Nepal had time and again appealed for the quelling of democratic armed forces based in India. In 1950, King Tribhuvan, who was under house arrest, fled to the Indian Embassy in Kathmandu and subsequently to India to seek asylum. The King's departure was followed by armed attacks by Nepali Congress launched across Nepal, resulting in Nepal's emergence as a constitutional monarchy;

Krishna Kant Adhikari, "The Status, Powers and Functions of Rajas and Rajautas during the Nineteenth Century Nepal in the Light of Contemporary Documents," Contributions to Nepalese Studies VIII, no. 1 (1980).
} 
such a move prevented the area around British India from external control or subjugation. ${ }^{78}$ Essentially, the British used the "forward policy" as a means to create a buffer zone encompassing Nepal, Bhutan, and Sikkim -nominally independent smaller countries in the northern periphery of the Empire.

The British conception of the buffer system in the region maintained its relevance even after the independence of India. The post-independence Indian administration inherited the British colonial apparatus including its geopolitical conceptualization of the region. Nepal continued to serve as a buffer state; Tibet acted as a buffer state too but very briefly. Nepal's buffer role became especially pronounced since Tibet's incorporation into the People's Republic of China. ${ }^{79}$ New Delhi sought to maintain the "Himalayan frontier policy" in Nepal, by keeping it under India's sphere of influence. ${ }^{80}$ The first Prime Minister of independent India, Jawaharlal Nehru, highlighted Nepal's importance to India's security. His rhetoric affirmed Nepal's sovereignty yet showcased concerns regarding Chinese activities in Tibet; Nehru iterated that "India would not tolerate any invasion of Nepal from anywhere." ${ }^{\prime 81}$ On December 7, 1950, Nehru's speech initiating the debate on foreign affairs in the Indian Parliament, highlighted Nepal's significant role for the security

${ }^{78}$ Krishna Kant Adhikari, "The Status, Powers and Functions of Rajas and Rajautas during the Nineteenth Century Nepal in the Light of Contemporary Documents," Contributions to Nepalese Studies VIII, no. 1 (1980). Accessed at the National Archives of India, New Delhi, India on July 4, 2016.

${ }^{79}$ Werner Levi, “Bhutan and Sikkim : Two Buffer States,” The World Today 15, no. 12 (1959): 492.

${ }^{80}$ Rabindra Mishra, “India’s Role in Nepal’s Maoist Insurgency,” Asian Survey 44, no. 5 (2004): 629.

${ }^{81}$ See Nehru's speech delivered to Parliament on March 17, 1950 in Avtar Singh Bhasin, ed., Nepal-India, Nepal-China Relations volume 1 (Delhi: Geetika Publishers, 2005): 84. 
of post-independence India. Titled "Peace or War," Nehru highlighted the following points regarding Nepal's importance to Indian security:

“We (India) recognize Nepal as an independent country and wish her well. But even a child knows that one cannot go to Nepal without passing through India...We wished to treat Nepal as an independent country but, at the same time, saw that, unless some steps were taken in the internal sphere, difficulties might arise...During the last fortnight, some new developments have taken place in Nepal. Our interest in the internal conditions of Nepal has become still more acute and personal, because of the developments across our borders, to be frank, especially those in China and Tibet. Besides our sympathetic interest in Nepal, we were also interested in the security of our own country. From time immemorial, the Himalayas have provided us with a magnificent frontier. Of course, they are no longer as impassable as they used to be but are still very effective. We shall not allow that barrier to be penetrated because it is also the principal barrier to India. Therefore, much as we appreciate the independence of Nepal, we cannot allow anything to go wrong in Nepal or permit that barrier to be crossed or weakened, because that would be a risk to our own security..., 82

82 "Peace or War" in Jawaharlal Nehru's Speeches: Volume Two (August 1949-February 1953) (New Delhi, India: Publications Division: Ministry of Information and Broadcasting, Government of India, 1963), 256-57. 
Nehru's speech reinforces India's conception of Nepal as a buffer state - one that became even more prominent with Tibet's incorporation into the People Republic of China. It highlights the predicament of the buffer state that it may not truly enjoy external intrusion as its geopolitical position makes it susceptible to the security concerns of its neighbors. The long border shared between Tibet and Nepal made the latter very sensitive to Indian security concerns as the former ceased to exist as a buffer. Thus, Nepal retained a prominent place in Indian foreign policy; in fact, its importance as a geopolitical buffer increased after the 1950 incursions of the People's Liberation Army (PLA) into Tibet, a continuation and perhaps, exacerbation of Nepal's importance for India's own geopolitical security.

Tanisha M. Fazal offers a very different perspective on the buffer state. Her book State Death: The Politics and Geography of Conquest, Occupation, and Annexation has a whole section on the buffer state concept within the context of demise of states. Fazal comes to the conclusion that buffer states will be in a higher risk group for violent state death; her exception is that in the post-1945 period, a state is 92 per cent more likely to survive than a state did in the pre-1945 period ${ }^{83}$ In summary, the chances of destruction of a buffer state (or any other state for that matter) becomes almost nil in post-1945 period, showcasing the strengthening norm of territorial integrity and sovereignty. Of course, this does not take into account territorial disputes that have endured in the post-1945 period but the idea of a whole state disappearing is unthinkable in the present context. Nevertheless, her research emphasizes the shift in international norms pre- and post- 1945; the end of the

\footnotetext{
${ }^{83}$ Fazal, State Death, 79-80.
} 
Second World War and the beginning of decolonization entrenched sovereignty and severe negative sanctions in forceful change of territorial status-quo. However, Fazal maintains skepticism of the viability of the buffer state. She states that:

"states engaged in enduring rivalries form security dilemmas around the states that lie between them-buffer states. And it seems that these buffer states are born to lose. Each rival fears the possibility that its opponent will take over the buffer. This fear produces a strategic imperative that leads to a fatal outcome: buffer state death.

Buffer states are likely to die because surrounding rivals are typically unable to make credible commitments not to take them over. But in certain, atypical situations, the security dilemma can be resolved such that buffer states survive. If rivals' resources are simultaneously constrained, they cannot take over buffer states. If rivals must become temporary allies in another theater, they prefer not to sap each other's resources by fighting over buffer states. And if a more powerful third party intervenes to protect the buffer state, rivals will refrain from conquest because costs will exceed benefits. ${ }^{\prime 84}$

${ }^{84}$ Fazal, State Death, 229. 
Fazal's work offers a historical perspective of buffer states and their precarious existence. She does acknowledge that buffer states have survived since before 1945, as is the case for Nepal (and Bhutan). Her research infers that balancing by buffer states has not always led to their survival; additionally, buffer states can rarely make alliances because of the very fact that they are buffer states - their precarious position between two rival powers does not allow them to choose favorites without the risk of irking one of the powers. ${ }^{85}$ Overall, Fazal offers a historically grounded analysis of buffer states and their propensity towards state death. Yet, her work does not explain buffer states in the present international political context. She explains the entrenchment of the norm against conquest and state death after 1945 but her work does not include the present role of buffer states. Fazal's observations enrich the buffer state literature; yet, the scope of her work is to assess survival/death trajectories of states. It is not to explain the relevance of buffer states in contemporary international politics and their role in regional security.

The classical geopolitical thinkers opened up a new avenue of political thinking with implications for International Relations. Classical geopolitical thinkers did not directly deal with buffer states. Nevertheless, their emphasis on the political nature of geographic space and the influence of topography on foreign policy paved the way for the emergence of a more detailed analysis of buffer states. Geopolitics divulged a new line of analysis focused on strategic importance of space, a fact that was not novel in military strategy but was groundbreaking as an analytical tool. The emphasis of Geopolitics on the political utility of geographic space and implications of natural topography led to academic

${ }^{85}$ Fazal, State Death, 230. 
discussions on the topic. Buffer states became subjects of study as well but to a limited extent. The literature on small states seems to be more developed due to its wider scope and is thus, discussed here due to its implications for buffer states

\section{On Sub-Systemic Powers, Rivalry, and Geographic Contiguity}

The very existence of buffer states is tied to the behavior of sub-systemic powers. ${ }^{86}$ While buffered states may not always be Great Powers, they maintain substantial regional influence. As such, it is pertinent to include the literature on sub-systemic powers and their patterns of behavior due to the relevance on how they impact buffer states. Just like buffer states, there is no singular definition of a sub-systemic power. Stewart-Ingersoll and Frazier (2010) classify such powers based on four parameters: the region under study, superiority of power capabilities in the respective region, possession of the largest power share in the region, and them exercising some kind of influence in the region. ${ }^{87}$ Regional powers are also defined as materially preponderant actors relative to other actors within the same region. ${ }^{88}$ While some sub-systemic powers can certainly also be systemic powers (i.e. Great Powers), not all of them are. Nevertheless, sub-systems are characterized by regional

\footnotetext{
${ }^{86}$ Sub-systemic powers can also be referred to as regional powers.

${ }^{87}$ Robert Stewart-Ingersoll and Derrick Frazier, "India as a Regional Power: Identifying the Impact of Roles and Foreign Policy Orientation on the South Asian Security Order," Asian Security 6, no. 1 (2010): 51-73.

${ }^{88}$ Miriam Prys, Redefining Regional Power in International Relations: Indian and South African Perspectives (London, UK: Routledge, 2012), 17.
} 
hierarchies, wherein regional powers maintain preponderance within their respective regions. ${ }^{89}$

Material capability is an important factor in deciphering the behavior and influence of sub-systemic powers. Nevertheless, some authors argue that ideational factors matter. Regional powers attempt to shape the aspirations of their respective regions, including regional agendas and outcomes of their regional settings. ${ }^{90}$ Apart from the greatest share of power within a region, sub-systemic powers use their asymmetric advantage to provide public goods. ${ }^{91}$ Such public goods could be institutionalized at the regional level or enforced through bilateral means; either way, regional powers have the capacity to design regional agenda. Thus, the buffer state maintains a precarious position given that it is likely to find itself in contrasting regional designs; buffer states are geopolitically situated in areas where two or more sub-systems convene. The congruence of contending regional aspirations of sub-systemic powers makes the existence of buffer states precarious. It is worse for buffer states that are in between rising sub-systemic powers, as change in power dynamics are highly likely in such sub-systems.

While sub-systemic powers are the most powerful and influential players in their respective regions, intent of such states should be considered. According to Myriam Prys,

${ }^{89}$ Osterud Oyvind, "Regional Great Powers," in Regional Great Powers in International Politics, ed. Iver B. Neumann (New York, NY: St. Martin’s Press Inc., 1992), 7.

90 Philip Nel, "Redistribution and Recognition : What Emerging Regional Powers Want," Review of International Studies 36, no. 4 (2010): 957.

${ }^{91}$ Sandra Destradi, "Regional Powers and Their Strategies: Empire, Hegemony, and Leadership," Review of International Studies 36, no. 4 (2010): 907. 
not all regional powers are alike; some of them are active in regional agenda making while others are apathetic. Her typology of regional powers includes three variations:

1. Dominant Regional Powers: Regional powers that promotes its own private goods provision and dominates over public goods provision of the region and uses force if need be.

2. Regional Hegemons: Regional powers which promote regional stability and promotes some common goods for the region without usage of force.

3. Detached Regional Powers: Regional powers that focus on international roles rather than local ones. ${ }^{92}$

In the buffer system, regional powers are invested in regional affairs, while extraregional interests may remain concurrent. The buffer state is based on the logic of contending interests of competing regional powers. Prys' third typology does not apply to the buffer system as the buffered states are locally active. Contending regional powers may view inactivity in regional affairs as concessions, weakening the influence of the regional actor that does not focus regionally.

Interstate rivalry has been a consistent facet of international system since the initiation of its study. Since a buffer state is situated between larger rival powers, the notion of rivalry requires contextualization and extrapolation of the concept. Thus, the nature of

${ }^{92}$ Miriam Prys, "India and South Asia in the World: On the Embeddedness of Regions in the International System and Its Consequences for Regional Powers," International Relations of the AsiaPacific 13, no. 2 (2013): 267-99. 
the buffer system makes it pertinent to touch on rivalry and its connection to geographic contiguity. The preliminary approaches to rivalry centered around what is considered "strategic rivalries." These rivalries are measured based on the number of conflicts that occur between two states within a specific period of time. ${ }^{93}$ One such approach based on dispute density is that of Diehl and Goertz (2000); two states are considered rivals if they militarily clash at least six times over the period of twenty years. ${ }^{94}$ Rivalry is clearly defined here in terms of a military conflict, within a specified period of time.

D. Scott Bennett highlights a similar approach used by Wayman and Jones (1991), which also put forth a similar operationalization based on reciprocated militarized conflicts. It includes three main conditions: first, there must be at least thirty days each between two states; second, there must be at least twenty-five years between the outbreak of the first dispute and the termination of the last dispute; third, if the gap between any two militarized disputes exceeds ten years, an enduring rivalry continues only if the territorial domain and issues remain unresolved and there is at least one militarized dispute within a period of twenty-five years. ${ }^{95}$ But, this approach is seen as rather constricting the utility of studying rivalry and its impact on conflict scenarios; similar to Diehl and Goertz's argument, Thompson provides a stable initiation in the study of rivalry but it lacks the ability to explain rivalries that do not entail military conflict. ${ }^{96}$

\footnotetext{
${ }^{93}$ William R. Thompson, "Identifying Rivals and Rivalries in World Politics," International Studies Quarterly 45, no.4 (2001): 558.

${ }^{94}$ Ibid., 569.

95 D Scott Bennett, "Security, Bargaining, and the End of Interstate Rivalry," International Studies Quarterly 40, no. 2 (1996): 170-171.

96 Thompson, "Identifying Rivals and Rivalries in World Politics," 558.
} 
Another perspective on the factors determining rivalry deals with threat perception. Rivals are usually dyads with equal capability, as they cannot impose each other's will on the other, further spurring conflict of interests. ${ }^{97}$ Thus, there is a conscious conceptualization of what rivalry with another state entails. Mitchell and Thies (2011) present a two-dimensional measure of rivalry: an issue dimension that includes the number of distinct diplomatic issues between a dyadic interaction and secondly, a military dimension that includes the number of militarized attempts to settle a particular issue. ${ }^{98}$ Multiple conceptions of rivalry imply that it is not just limited to militarized issues but also broader policy objectives - a rivalry, more often than not, entails a military dimension. The predicament of the buffer state can be conceptualized within this notion of rivalry, wherein rivalrous relationships beyond militarized conceptions play a role in dyadic Great Power or Middle Power interactions.

Analyzing the buffer state within the context of rivalry requires the inclusion of geographic contiguity, as buffer systems are sets of geographically contiguous states. Adding the nuance of geographic contiguity in assessing spatial rivalry brings forth the importance of studying interactions at the border frontiers between powers. Although militarized rivalries may not be the only expressed form of a rivalrous relationship between powers, it is important to note that territorial dispute could pose as a source of serial

97 Thompson, "Identifying Rivals and Rivalries in World Politics," 560.

${ }^{98}$ Sarah McLaughlin Mitchell and Cameron G. Thies, "Issue Rivalries," Conflict Management and Peace Science 28, no.3 (2011): 231. 
episodes of conflicts. ${ }^{99}$ Diehl argues that if a dispute is contiguous by land, the likelihood of escalation of violence is increased. ${ }^{100}$ It is due to the fact that geographic contiguity provides a setting amenable to conflictual interactions. ${ }^{101}$ Contiguous states simply do not enter into a conflict (be it military or diplomatic) due to their contiguity. Such states have to see an opportunity - identify a policy of interaction within its means, while at the same time be willing to pursue such policies. ${ }^{102}$ Thus, territorial contiguity remains an important aspect of interstate rivalries. Given the importance of contiguity in rivalries, it is pertinent to assess the buffer state's predicament within this context. Nevertheless, the impact of geographically contiguous rivalries on buffer states cannot be understated.

The nexus of geographic contiguity and rivalry can be assessed through the lens of the emerging importance placed on the sub-system. Sub-systems or regions, by definition, are geographically contiguous or proximate blocs of states. The inherent geopolitical nature of a buffer system makes it a concept that is strongly bonded by geographic contiguity, which can sometimes manifest in the form of a rivalry. The condition for rivalry is especially more pronounced if the two geographically contiguous states are rising powers, which have increasing capabilities.

${ }^{99}$ Cameron G. Thies, "Territorial Nationalism in Spatial Rivalries: An Institutionalist Account of the Argentine-Chilean Rivalry," International Interactions: Empirical and Theoretical Research in International Relations 27, no.4 (2001): 404.

${ }^{100}$ Paul F. Diehl, “Contiguity and Military Escalation in Major Power Rivalries, 1816-1980,” The Journal of Politics 47, no.4 (1985): 1206.

${ }^{101}$ Paul D. Senese, "Territory, Contiguity, and International Conflict: Assessing a New Joint Explanation," American Journal of Political Science 49, no. 4 (2005): 770.

${ }^{102}$ Ibid. 


\section{On the Continued Relevance and Utility of the Buffer State Concept in International Relations}

As aforementioned, the concept of buffer states is not a new one. Its conceptual utility remained prevalent since the time of the Roman Empire. Nevertheless, academic endeavors on the concept only began in the late $19^{\text {th }}$ and early $20^{\text {th }}$ centuries. As Geopolitics emerged as a separate academic discipline, so too did the buffer state become relevant as a concept with analytical utility. Mary Gear's work remains one of the first to directly address the buffer state as an analytical concept. She categorized buffers into three categories: natural, politico-natural, and political buffers. ${ }^{103}$ Her affirmation that buffer states are products of politics alludes to the strategic nature of such states; they fulfill a political function in the strategy of states. Gear goes to the extent of mentioning that buffers can change roles with changes in regional power levels; that such states can transform from a purely natural buffer to politico-natural buffers as well as purely political buffers. But Gear only merely mentions this without any details on how changes in the type of buffer state occur; what dynamics are inherent within the buffer state when such changes occur? How does change in neighboring power capabilities lead to changing of roles of the buffer state? These are some questions that Gear does not address in her short but novel work on buffer states.

While Gear narrows down the conception of buffer states, Michael Greenfield Partem further develops it. Pointing to the limitation of Trygve Mathisen's definition of buffer states as any small state lying in between two larger states, often rivals, Partem

${ }^{103}$ Gear, "Role of Buffer States in International Relations," 81-86. 
introduces more qualifications to identify such states, namely geography, capability distribution, and foreign policy orientation. ${ }^{104}$ While Mathisen addresses the predicament of the buffer state within the context of the role of small states in the strategy of larger powers, his assessment is limited to defining the buffer state. Mathisen offers very little in his book on the nuances related to buffer states, without references to their role in regional security dynamics. As for Partem, he asserts that geography entails the fixation of the buffer state's geopolitical significance, a fact that remains a reality for all of that state's existence. Partem also operates Bueno de Mesquita's framework for analyzing the calculations of rational unitary actors during conflict situations. Basically, the argument he is forwarding rests on relative capability distribution; through probability and utility calculations, a state's likelihood of initiating conflict can be measured. ${ }^{105}$ A more specific indicator of a buffer state's existence is the relative disparity in capability between the buffer state and the two buffered states it separates. The buffer state is simply "smaller" than the two larger buffered states while assessed relatively.

Partem adds a critical nuance to the literature on buffer states: the notion of deutilization. It entails the conscious effort by the buffer state to remain comparatively weak to ensure that any action against it was viewed as a blatant act of aggression in the international arena. ${ }^{106}$ In addition, the utility of a buffer is framed in the wider context of

${ }^{104}$ Partem, "The Buffer System in International Relations," 4.

105 Partem, "The Buffer System in International Relations," 6-7;

Bruce Bueno de Mesquita, "Measuring Systemic Polarity," The Journal of Conflict Resolution 19, no.2 (1975), 187-88.

${ }^{106}$ Mesquita, "Measuring Systemic Polarity," 9. 
the larger powers' strategic calculations - a buffer state might become highly important for the larger powers if it fulfills their strategic needs. Partem's third characteristic of buffer states rests on foreign policy orientations. His characterization rests on alliance formation; buffers can remain aloof of involvement between the larger powers or choose a side. What the buffer chooses to pursue determines the military strategy of both of the larger buffered states. Nevertheless, buffers do recognize the dangers inherent in choosing a side - the reason why many of them declare neutrality.

As for buffer diplomacy, Afghan king Amir Abdur Rahman compared his country to a swan on a lake, with a bear on one shore and wolves on the opposite shore. ${ }^{107}$ The metaphor of Afghanistan as a swan poetically captures the delicate balancing act inherent in buffer state diplomacy. However, buffers do not always maintain neutrality and that factors such as changes in capability of the buffered states, domestic upheavals, and intense regional rivalries can push buffers to lean to one side. Overall, Partem elaborates on Gear's definition of the buffer state, providing more nuance to its regional predicament and foreign policy. Despite these additions to the literature, Partem does not provide a detailed account of how rivalries between the buffered states unravel within the buffer state; he does mention the changing stance of buffer to changes in capabilities of the buffered states but Partem does not elaborate on how such changes take place.

The earliest book on the specific topic of buffer states is titled Buffer States in World Politics edited by John Chay and Thomas E. Ross. This work probes the conditions, problems, and prospects of buffer states and buffer zones. The book further seeks to

${ }^{107}$ Stephen Wheeler, The Ameer Abdur Rahman (London, UK: Bliss, Sands, and Foster, 1895), 137. 
address the nature, characteristics, structure, and operation of a buffer state. The major objective of the edited volume rests on its attempt at explaining problems experienced in politically troubled areas, through the study of the structure and operation of the buffer state. Thomas E. Ross extends the definition of the buffer state, linking it to how it could be explained from the perspective of a geographer. Ross furthers the case that geographic location is paramount despite technological advancement but from the perspective of geography; he asserts the primacy of geography, particularly hostile terrain as being critical in the designation of a buffer state.

As for the buffer's foreign policy, Joseph Maila argues that it espouses the notions of sovereignty, autonomy, neutrality, and freedom. In another chapter by Philip Kelly, it is argued that buffer states contribute to regional political dynamics and such states remain permanent fixtures despite political changes in the region. What Kelly does not incorporate is the changing nature of the buffer state's role in the regional setting. How does the change in capability of vicinal powers affect its the behavior? This question remains unanswered in his analysis. Despite the limits on the evolution of buffer's role and its relation to subsystemic changes, Gerald L. Ingall's chapter does acknowledge the changing nature of buffer states. Furthermore, he concisely rounds up the literature section of the chapter by addressing the systemic requirement of a buffer system - that the buffered states need to be significantly more powerful than the buffer itself and they need to be able to maintain some degree of sovereignty. Overall, Chay and Ross's work provides a much needed and detailed definition of a buffer state, including its systemic role and an explanation for why many of the troubled regions in the world are buffer systems. 
Despite this groundbreaking work on buffer states, the book provides little to no explanations for the changing roles of buffer states. Phillip Kelly does touch on regionally stabilizing role played by buffer states but none of the authors in the edited volume address how changing regional power capabilities in the vicinal states lead to transformations within the buffer state. What accounts for buffer states titling from one power to neutrality or vice-versa as well as how the competition between regional powers plays out in the buffer state is important to decipher their roles in regional security. These questions are not directly addressed in any of the chapters in the book. In essence, the authors do not account for changes in power capabilities and how they affect the status of the buffer state, a crucial point in maintenance of its relevance in contemporary International Relations.

Lawrence Ziring approaches the topic from a perspective that emphasizes the military-political conditions of the international system, which is in line with the Classical Geopolitical approach towards buffer states. According to him, buffer states are not buffers by choice; it is thrust onto them by a hostile international environment. ${ }^{108}$ Such states are "extensions of balances of power, not international law" - it is implied that buffer states are outgrowths of necessities borne out of peculiar conditions in military and political relations. He adds that buffer states are usually the first victims due to the virtue of their geographic disposition; their status oscillates between a loss of national pride on one hand and extinction on the other. In essence, Ziring presents a rather bleak diagnosis, one that is mired with lack of prospects of agency for the buffer state. While Ziring's approach to

${ }^{108}$ Lawrence Ziring, "Buffer States on the Rim of Asia: Pakistan, Afghanistan, Iran and the Superpowers," in Soviet-American Relations with Pakistan, Iran and Afghanistan, ed. Hafeez Malik (New York, NY: Palgrave Macmillan, 1987), 90. 
buffer states was relevant during the $18-20^{\text {th }}$ centuries when borders changed constantly, it may not hold much weight in the post-WWII period. It is even more unlikely after the end of the Cold War. The emphasis on national sovereignty and the norm of non-interference largely make the extinction of the buffer state an exception rather than a norm. As such, the context surrounding buffer states has changed. They may be small states in precarious geopolitical predicaments, but they do have limited agency to influence the interplay of the buffered states. Ziring's typification of buffer states renders them to be passive players in interstate politics and does not adhere to the norm of upholding territorial integrity, while sidelining the agency (albeit limited) of buffer states in the buffer system.

Another book, which is the most recent one exclusively dealing with the concept of the buffer state is Tornike Turmanidze's Buffer States: Power Policies, Foreign Policies, and Concepts. ${ }^{109}$ He provides a good review of the limited literature on the concept of the buffer state but also adds to it. His work extends the concept of a quasi-buffer - a buffer state that only fulfills the security function of one of the bigger power it shares borders with. These are states that are not entirely buffers as they hold strategic significance for only one of the two powers it separates. While Turmanidze offers a concise and compressed review of the majority of the authors discussed in the preceding paragraphs, his work mainly seeks to further the concept of the quasi-buffer while distinguishing it from the traditional buffer state. It is a short book that mainly reiterates already existing literature on the buffer state. As for the foreign policy of buffer states, Turmanidze asserts that neutrality is the preferred policy, especially during conflicts between the buffered states.

${ }^{109}$ Tornike Turmanidze, "Buffer States: Power Policies, Foreign Policies and Concepts,” 2012. 
Turmanidze argues that quasi-buffers go against the notion of neutrality by allying themselves with one of the two larger powers. But what seems to be lacking is the notion of changes in power capability - what happens to the quasi-buffer if the power against which it is allied raises its power capability? There is a high possibility of the rising buffered state to increase its influence in the buffer, which no longer remains what Turmanidze calls a quasi-buffer. Thus, he does not account for the dynamic nature of subsystems and the sub-systemic interactions within the buffer state. Also, very little is touched on how such role conceptions of buffer change with changing sub-systemic power capabilities. The dynamic nature of the interactions of larger powers in the buffer state is also untouched by Turmanidze's work.

Martin J. Bayly writes a refreshing piece on the buffer state concept. His work is perhaps the latest one that seeks to tackle the predicament of buffer states. Bayly offers an alternative to the structural-functionalist approach to buffers that renders them to be heavily dependent on the great powers for maintaining any semblance of relevance. ${ }^{110}$ He proposes using ontological security i.e. moving beyond just physical security to security of the self when analyzing buffer states. He categorizes such structural-functionalist approaches as ahistorical and limited to understanding the buffer system in terms of "two rival powers straining over an intervening state, a classic security dilemma in which neither wishes to provoke war, yet where both are weary of each other making strategic gains." "111 Bayly's

\footnotetext{
${ }^{110}$ Martin J. Bayly, "Imperial Ontological (In)security: 'Buffer States', International Relations and the Case of Anglo-Afghan Relations, 1808-1878," European Journal of International Relations 21, no. 4 (2015): 819 .

${ }^{111}$ Ibid., 834.
} 
deployment of ontological security as a lens for analyzing buffer systems promotes their representational forms as 'zones of competition' or as 'imaginative geographies.' In essence, Bayly's process takes into account the identities of states, including British ontological insecurity in Afghanistan which resulted after failed routinization attempts. While Bayly's argument adds a fresh perspective to the slim amount of literature on buffer states, it does not take the material forces into account. Ontological security does figure profoundly in the foreign policy of the buffer states as well as the buffered states, but both material and rhetorical forces are important in deciphering the dynamics of relations. While identity could be a prelude to the occurrence of political maneuvering, it is quintessential in accounting for the importance of rhetoric and the usage of material forces for strategic gain.

The buffer state concept has maintained its relevance in international politics in more than one form. Paul Poast uses buffer states as test cases for assessing whether alliance commitments are credible. ${ }^{112}$ His argument is that buffer states have contentious existence given their proneness to invasion and occupation; while this may not hold true in totality in the contemporary normative structure of international politics, his argument is focused on whether issue linkages bolster treaty obligations. His findings allude that buffer states in alliances with trade provisions experience fewer willful violations of alliance obligations, fewer attacks, and almost no experience of invasion and occupation than those do not have trade provisions. ${ }^{113}$

\footnotetext{
112 Tornike Turmanidze, "Buffer States: Power Policies, Foreign Policies and Concepts," 2012. ${ }^{113}$ Ibid., 58.
} 
The literature on buffer states covers a wide variety of arguments, but a majority are concerned with defining the buffer state itself. Due to the relative lack of theoretical attention to the concept, much of the preceding decades have been spent on providing a sound conceptual basis for the buffer state. Chay, Ross, and Partem have delved deeper, attempting to foster a deeper understanding of the buffer state. Foreign policy orientations as well as centrality of state contextualization at the regional level have been covered. But a major gap in the field pertains to the changing role of buffer states; while the definition of the buffer does not change due to its vicinal geography, its political meaning and importance can change. A buffer may be within the security umbrella of one of the powers, but such political tilting could change, pertinent to increase or decrease in power capability. Endeavors in linking changes in capabilities of buffered states to the changing importance of buffer state remains limited to mere descriptions and lacks analytical depth. In addition, not much has been attempted in how such changes in capability of one of the buffered states plays out in the buffer state. Since the buffer state is based on regional power competitions, it is highly likely that the same could play out in the buffer state as well. Thus, this proposed dissertation seeks to bridge that gap; it seeks to provide contextualization to the buffer state by linking its changing political role and significance to sub-systemic power changes. It takes the dynamic interactions of material and rhetorical forces of the buffered states in the buffer state. 


\section{CHAPTER III: RESEARCH DESIGN, CASE SELECTION, \& METHODOLOGY}

This chapter lays out the research design, case selection, and methodology of this dissertation. First, the chapter provides a brief synopsis of why mixed-methodology was used for this study and how it is tied to the research question. Secondly, the rationale for the usage of the India-Nepal-China Buffer System (INCBS) is extrapolated; this subsection also ties in the implications of India's and China's rise on sub-systemic relations, including implications for the buffer state in question, Nepal. Finally, the chapter provides a detailed lay-out of the methodology used in the study, including details on the convergent parallel design, and the tools for qualitative and quantitative data collection and analyses.

Overall, Chapter III provides the methodological framework for the dissertation and why the INCBS was chosen.

\section{$\underline{\text { Research Design }}$}

The nature of the research question of the dissertation requires a mixed-method research design. The research question seeks to ascertain the relevance and importance of buffer states by linking them to sub-systemic changes in power capabilities of the buffered states. The increase/decrease of sub-systemic rivalry in the buffer state is central to the research problem; buffer states maintain strategic relevance through this dynamic of the buffer system. Increase or decrease in relevance is operationalized as increase or decrease in rhetorical and material engagement with the buffer state; intensity of such engagement can be measured positively (through increase) or negatively (through decrease). The operational hypothesis is that if the buffer state has elevated relevance, there should be 
increase in the rhetorical importance extended by the buffered states; additionally, such intensified rhetoric needs to be coupled with increase in material aid extended to the buffer state. Thus, to capture the increased/decreased competition of the buffered states in the buffer state requires the analyses of the rhetoric being utilized as well as backing of that rhetoric through tangible means such as economic aid or investment, which are considered hard data due to their quantifiability. For a comprehensive analysis of both rhetorical engagement and material engagement, the mixed-method is best suited for the study. As Creswell and Plano state:

"As a methodology, it (mixed-methodology) involves philosophical assumptions that guide the direction of the collection and analysis of data and the mixture of qualitative and quantitative approaches in many phases in the research process. As a method, it focuses on collecting, analyzing, and mixing both quantitative and qualitative data in a single study or series of studies. Its central premise is that the use of quantitative and qualitative approaches in combination provides a better understanding of research problems than either approach alone.",114

Thus, the study is based on the idea that a mixed-methodology approach provides a more comprehensive explanation for the research problem. Quantitative data coupled with qualitative data would help in ascertaining whether higher/lower

${ }^{114}$ John W. Creswell and Vicki L. Plano Clark, Designing and Conducting Mixed Methods Research (Thousand Oaks, CA: SAGE Publications Inc., 2011), 5. 
sub-systemic rivalry between buffered states will result in greater or lesser competition in the buffer state; the rationale of this research design is to capture how the sub-systemic competition of the buffered states plays out in the buffer state. Using both quantitative and qualitative data aids in a more complete understanding of increase/decrease in intensification of rivalry in the buffer system. The following sections lay out the rationale for the case selection and detailed framework of the methodology used for this dissertation.

\section{$\underline{\text { Case Selection }}$}

Given the multitude of countries that fit the definition of a buffer state, the proposed study seeks to focus on only one buffer state, Nepal. Due to constrains in time and resources, the most prudent course of action for this dissertation was to conduct a withincase analysis of the India-Nepal-China Buffer system (INCBS). The within-case analysis entails "in-depth understanding and description of the phenomenon under study" wherein a single case is used as a standalone entity. ${ }^{115}$ The case's unique attributes and patterns are brought to the fore before attempting to locate general patterns and themes that exist across other cases i.e. other buffer systems. Within-case analysis "can be used initially to develop a standalone description of each case and then to conduct a cross-case comparison to identify what each case has in common, as well as what attributes about each case are unique. It can also be used to develop an initial coding tree." ${ }^{116}$ As such, this dissertation

\footnotetext{
115 Turmanidze, “Buffer States,” 2012.

116 Paterson, "Within-Case Analysis," 2.
} 
is an endeavor to create an analytical framework that can be used to assess and analyze other buffer systems. The within-case analysis used in this dissertation identifies several data points in the case study chosen, which are analyzed using a mixed-methodology; these data points, called historic critical junctures, are briefly introduced in the following subsections. They are fully elaborated in Chapter IV.

For the within-case analysis, this dissertation uses the India-Nepal-China buffer system, whereby Nepal is the buffer state while India and China are the buffered states. The rationale for using this case study is based on the increased interest in regions as units of analysis in International Relations coupled with the rising status of China and India in the international system. In the aftermath of the Cold War, regional approaches to security studies have garnered increased attention. ${ }^{117}$ As ideologically motivated bipolar bifurcation gave way for regional powers to assert themselves in their respective regions, avenues for sub-systemic analyses opened up as well. While systemic level political interactions still garner extensive attention, there has been a marked increase in the study of regional subsystems; this is especially true for the study of the role of regional powers in shaping their respective sub-systems. ${ }^{118}$ One such avenue that has dominated the discourse in security

${ }^{117}$ For more on regional/sub-systemic approaches to security, see: T.V. Paul, International Relations Theory and Regional Transformation (Cambridge, UK: Cambridge University Press, 2012); Benjamin Miller, International and Regional Security: The Causes of War and Peace (New York, NY: Routledge, 2017); T.V. Paul, South Asia's Weak States: Understanding the Regional Insecurity Predicament (New Delhi, India: Oxford University Press, 2011); Amitav Acharya, Non-Western International Relations Theory: Perspectives On and Beyond Asia (New York, NY: Routledge, 2010); Barry Buzan and Ole Wæver, Regions and Powers: The Structure of International Security (Cambridge, UK: Cambridge University Press, 2003); Rick Fawn, Globalising the Regional, Regionalising the Global (Cambridge, UK: Cambridge University Press, 2009); David Lake and Patrick M. Morgan (eds.). Regional Orders: Security in the New World (University Park: Pennsylvania State University Press, 1997).

${ }^{118}$ For other works that address the specific roles played by regional powers in their respective subsystems, see: Nadine Godehardt and Dirk Nabers, Regional Orders and Regional Powers (Oxon, UK: Routledge, 2011); Robert Stewart-Ingersoll and Derrick Frazier, Regional Powers and Security Orders: A Theoretical Framework (Oxon, UK: Routledge, 2012); Shinichiro Tabata, Eurasia's Regional Powers 
studies has been the rise of China, which is a major motivation for choosing the INCBS. Domestic reforms in China since Deng Xiaoping's time as Premier, accelerated China's economic growth and subsequently, its political clout. Regional approach to security studies provides sub-systemic context, which remains an important aspect for analyzing China's rise. The impact of the rise of a regional power is evidently felt in the immediate region. Thus, the study of the rise of China remains critical in the study of sub-systemic power dynamics. Furthermore, China increasingly showcases systemic relevance; it has soared to become the second largest economy in the world in a mere three decades. Substantial debates are occurring among International Relations scholars who seek to make sense of China's rise. The INCBS is part of China's critical role in the international system; its analysis is timely for a wholesome understanding of Chinese strategic behavior. The inclusion of India in the study allows for further extrapolation of China's strategic maneuvering in smaller states when another larger power is involved.

The swift rise of China has garnered extensive academic interest. One of the most prominent voices in the field, John J. Mearsheimer, provides a pessimistic account of China's emergence as a global power, arguing that China will seek to establish regional hegemony in Asia -- a region which already has the presence of another regional hegemon, the United States. ${ }^{119}$ Thus, conflict is inevitable as the status-quo regional hegemon will

Compared: China, India, Russia (New York, NY: Routledge, 2015); Miriam Prys, Redefining Regional Power in International Relations: Indian and South African Perspectives (London, UK: Routledge, 2012); Miriam Prys, "India and South Asia in the World: On the Embeddedness of Regions in the International System and Its Consequences for Regional Powers," International Relations of the Asia-Pacific 13, no. 2 (2013): 267-99.

119 John J. Mearsheimer, “China’s Unpeaceful Rise,” Current History 105, no.690 (2006): 160. 
use what is within its means to ensure that another regional hegemon does not emerge in the international system.

Stephen Walt's stance is somewhat similar to Mearsheimer's; he argues that significant security competition between China and the US is inevitable, with implications that will impact the entire international system. ${ }^{120}$ Thus, the rise of China will pose threats to the current system in place, as Walt projects China to make it increasingly dangerous for the U.S. to operate its security maneuverings in East Asia. He further argues that China may seek to distance America's neighbors through "divide and conquer" tactics.

Charles Glaser presents a more optimistic Realist approach by positing the idea that conflict is not predetermined. The outcome of China's rise depends more on how the American and Chinese leaders manage the situation rather than on the pressures generated by the international system. ${ }^{121}$ Thus, there are a variety of perspectives presented by Realist thinkers of International Relations regarding China's rise.

In contrast, prominent liberal institutionalist scholar Gilford John Ikenberry presents a perspective rooted in neoliberal institutionalism, whereby China is adhering to the norms of the system rather than challenging them as it has gained substantially from the system in place. ${ }^{122}$ Ikenberry argues that China's rise is not threatening to the statusquo system as it has successfully utilized the norms and institutions in place after the

${ }^{120}$ Stephen M. Walt, “China’s New Strategy,” Foreign Policy, 2010, http://foreignpolicy.com/2010/04/26/chinas-new-strategy/.

${ }^{121}$ Charles Glaser, “Will China’s Rise Lead to War?” Foreign Affairs 90, no.2 (2011): 80-91.

122 J. John Ikenberry, "The Rise of China and the Future of the West: Can the Liberal System Survive?” Foreign Affairs 87, no.1 (2008): 23-25. 
Second World War to secure its material ascent, which has started to translate into greater prestige and military capability in the system. Alastair Iain Johnston presents a middle-ofthe-road argument regarding China's status as a revisionist or status quo power. He posits that, "The Chinese leadership does not appear to wish to pay much in terms of its economic development interests or its relationship with the United States. In other words, the wish to be richer and more powerful has not translated into a concerted military effort to replace the United States as the pre-dominant state regionally or globally." 123

China's rise in the international hierarchy of states certainly impacts systemic configurations of power but its long-term implication is a subject of considerable debate. Consequently, regional power dynamics are impacted as they are inadvertently tied to such changes. Within the context of China's rise, India is the only other rising power that is touted to present the most credible regional (and potentially, global) challenges for China in the upcoming decades, mainly due to its demography and growing economy. ${ }^{124}$ India is set to become the world's most populous state and has been experiencing significant economic growth since the commencement of economic liberalization in the early 1990s. Additionally, other powers such as Japan and the United States, both wary of a rising China, have increasingly sought to court India as a counterweight to China. ${ }^{125}$ Despite implications

\footnotetext{
${ }^{123}$ Walt, "China’s New Strategy."

${ }^{124}$ Kori Schake and Anja Manuel, "How to Manage a Rising Power - or Two," The Atlantic, May 24, 2016, accessed at https://www.theatlantic.com/international/archive/2016/05/china-india-risingpowers/484106/.

125 Annie Gowen, "U.S. Military wants India to Counterbalance China's Rise as a Sea Power," The Washington Post, June 5, 2016, accessed at https://www.washingtonpost.com/world/asia_pacific/usmilitary-wants-india-to-counterbalance-chinas-rise-as-a-sea-power/2016/06/05/5caf6f24-280a-11e6-8329-

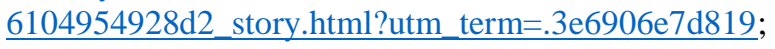


for regional and global security, there is a limited but growing literature on Sino-Indian interactions. Analysis of how this rivalry manifests itself in the smaller states of Asia, a region both rising powers share, is even more limited.

The rise of China is causing sub-systemic changes as it asserts itself regionally. The rivalrous Sino-Indian dyad qualifies as the best case for this proposed dissertation, as subsystemic power changes in the form of China's rise is aggravating Sino-Indian relations. The Sino-Indian relationship can be characterized as a rivalrous one, which can be traced back to the brief border war in 1962. The status over Arunachal Pradesh and Aksai China remain contentious as these border issues have yet to be resolved. ${ }^{126}$ Furthermore, India has housed the Dalai Lama since the failed Tibetan uprising in 1959, who is claimed by Beijing to be a separatist. ${ }^{127}$ In essence, the Sino-Indian relationship can be considered a rivalry when using Mitchell and Thies' framework; ${ }^{128}$ the issue dimension has largely been the border disputes between the two countries. As for the military dimension, the two states fought a war in 1962; recent incursions into the Doklam Plateau by the People's Liberation Army (PLA) of China caused tense military standoff between the India and Chinese militaries in the disputed region between China and Bhutan. ${ }^{129}$ This rivalrous relationship

Mitsuru Obe and Niharika Mandhana, "India and Japan Pursue Closer Ties to Counter China," The Wall Street Journal, September 1, 2014, accessed at https://www.wsj.com/articles/indias-primeminister-narendra-modi-wants-closer-ties-with-japan-to-counter-china-1409555754.

126 Surjit Mansingh, "India-China Relations in the Post-Cold War Era,” Asian Survey 34, no.3 (1994): 285-300.

127 “China Calls Dalai Lama a 'Separatist', Says he Fled After Failed Armed Rebellion,” The Hindustan Times, April 8, 2017, accessed at https://www.hindustantimes.com/world-news/china-callsdalai-lama-a-separatist-says-he-fled-after-failed-armed-rebellion/story-zDQ7oFcG4D7UFNdblP3DlK.html.

${ }^{128}$ Mitchell and Thies, "Issue Rivalries."

129 Subrata K. Mitra and Srikanth Thaliyakkattil, "Bhutan and Sino-Indian Rivalry," Asian Survey 58, no.2 (2018): 240-260. 
is set to intensify as both China and India are undergoing extensive economic growth and modernization of their militaries.

This intensified contentious relationship between India and China is impacting smaller states in the region, including South Asia. As part of the buffer system with Nepal, changes in Sino-Indian power dynamics present an opportunity to extrapolate how subsystemic changes provide relevance to buffer states through political competition within such states. The triadic buffer system consisting of India, Nepal, and China fits the scope of the study given the intense sub-systemic rivalry between India and China, including their increasingly intense competition within Nepal. Additionally, there is some literature on how India and China are courting Nepal ${ }^{130}$ - a tell-tale sign of the relevance of Nepal as a strategically important state for both of its neighbors. Thus, the India-Nepal-China buffer system is a reasonable fit as case study for this dissertation as its relevance is bound to increase due to the intensification of contrasting interests of India and China.

In addition, most of the literature on the triadic relations between India, Nepal, and China lack significant depth. Literature on the topic does exist. ${ }^{131}$ However, the most recent

${ }^{130}$ Some of these works include the following:

John W. Garver, "China and South Asia," Annals of the American Academy of Political and Social Science 519, no. January (1992): 67-85;John W. Garver, "The Diplomacy of a Rising China in South Asia," Orbis 56, no. 3 (2012): 391-411, doi:10.1016/j.orbis.2012.05.007; Manish Dabhade and Harsh V. Pant, "Coping with Challenges to Sovereignty: Sino-Indian Rivalry and Nepal's Foreign Policy," Contemporary South Asia 13, no. 2 (2004): 157-69; Bibek Chand, "Disaster Relief as a Political Tool: Analysing Indian and Chinese Responses after the Nepal Earthquakes," Strategic Analysis 41, no. 6 (2017): 535-45; Nihar Nayak, "Involvement of Major Powers in Nepal Since the 1990s: Implications for India," Strategic Analysis 33, no. 1 (2009): 41-53; John W. Garver, "China-India Rivalry in Nepal: The Clash over Chinese Arms Sales," Asian Survey 31, no. 10 (1991): 956-75.

131 John W. Garver, "The Diplomacy of a Rising China in South Asia," Orbis 56, no.3 (2012) - he touches on the Sino-Indian rivalry and its manifestation in Nepal but does not include the buffer state concept; John Garver, "The Security Dilemma in Sino-Indian Relations," India Review 1, no.4 (2002) - tackles the Sino-Indian relations through the conceptual framework of the security dilemma but no linkage of the security dilemma to the buffer state concept; Manish Dabhade and Harsh V. Pant, "Coping with the Challenges to Sovereignty: Sino-Indian Rivalry and Nepal's Foreign Policy," Contemporary South Asia 13, no.2 (2004) - 
book on the subject by Sanjay Upadhya does not incorporate the conceptual framework of the buffer state. ${ }^{132}$ Rather, his work details China's increasing interest in Nepal, which is a state that has traditionally been considered to be under India's security umbrella. Although rich in detail, Upadhya does not deploy the analytical framework of the buffer state. Thus, there is a significant lack of academic effort in situating the changing role of buffer states in regional security, particularly when it comes to changes in sub-systemic power capabilities and the implications for buffer states. The within-case analysis of the INCBS is appropriate for this study as it allows for a comprehensive explanation for the research question of this dissertation, including additional development of the theory related to buffer states. ${ }^{133}$ Furthermore, much of the work on the triadic India-Nepal-China relationship has been contextualized within the mainstream theories of International Relations, which pay scant attention to buffer states. Thus, there is a lack of in-depth explanations on the role played by buffer states in the international system, particularly in sub-systems that are characterized by enmity.

The rationale for the usage of the India-Nepal-China buffer system is a culmination of several factors. The rise of regional sub-systemic approaches to security studies,

Dabhade and Pant approach the trilateral relationship between India, China, and Nepal through an offensive realist perspective without the buffer state concept being tackled. Literature related to Sino-Indian rivalry touches mostly on security concerns between the two larger powers, with little attention paid to the conceptual framework within which the buffer system operates.

132 Sanjay Upadhya, Nepal and the Geo-Strategic Rivalry between India and China (New York, NY: Routledge, 2012) - Upadhyaya's book is rich in detail and history of this triadic relationship but it does not incorporate the concept of the buffer state and also does not touch on the transformative nature of the sub-systemic relationship, particularly when it comes to the changing context of geopolitical concepts including that of the buffer state.

133 Andrew Bennett, "Case Study Methods: Design, Use, and Comparative Advantages," in Cases, Numbers, Models: International Relations Research Methods, eds. Detlef F. Sprinz and Yael Wolinsky (Ann Arbor, MI: Michigan University Press, 2004), 38. 
increased attention to rising regional powers China and India, and the limitations in buffer state literature all contributed to why the INCBS was chosen as the case study for the dissertation. As it seeks to rekindle the importance of buffer states in regional security dynamics, INCBS is a strategic and timely choice for the study. It is a dynamic case that has a lot to offer the scant literature on buffer states and can be developed as a prototype analytical framework which can be used to assess other buffer states. In addition, the INCBS is precarious given the contending interests of China and India. Figure 3 showcases the depiction of the INCBS while Figure 4 depicts its geographic representation. 
Figure 3: The India-Nepal-China Buffer System

Sub-system

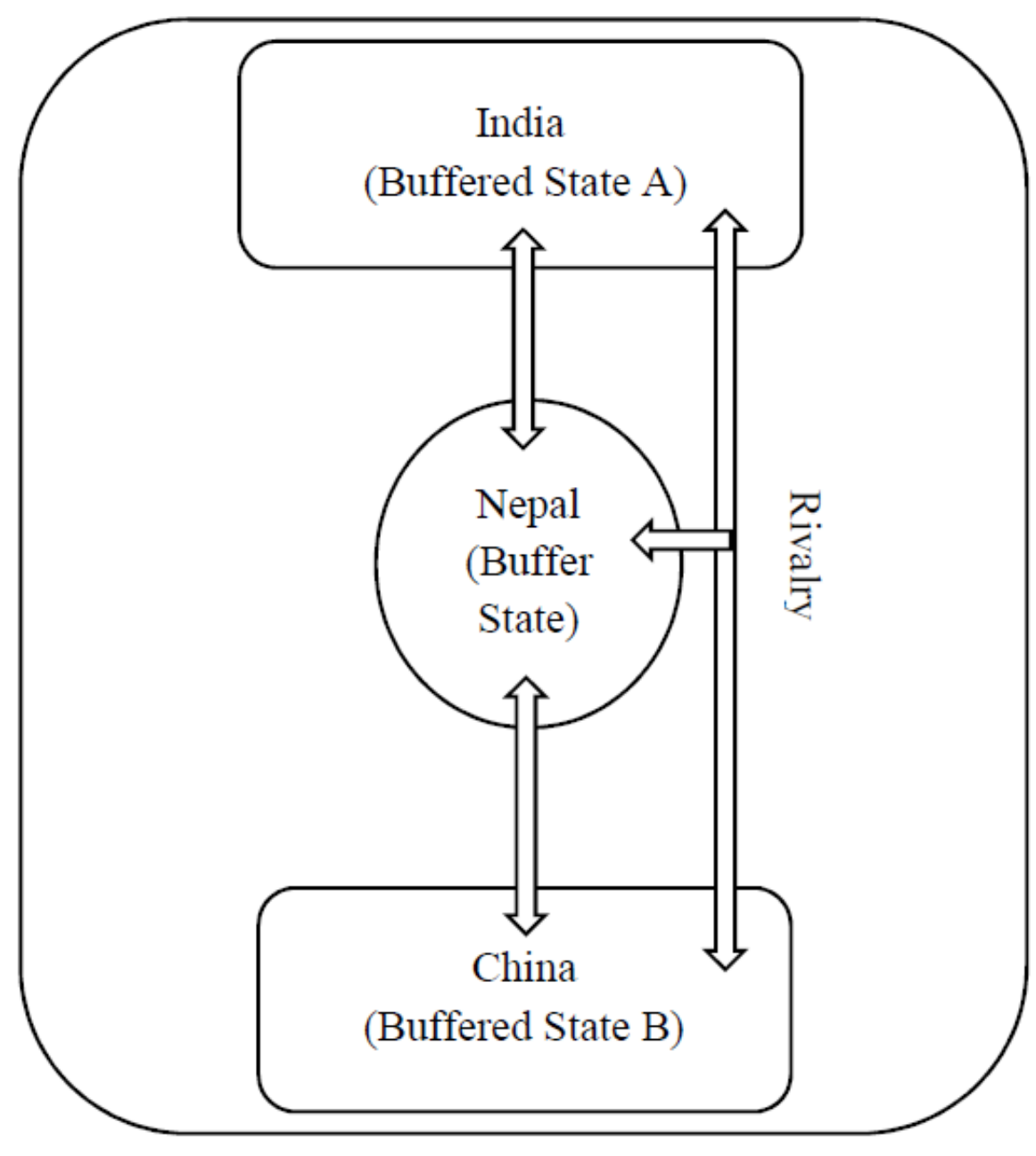


Figure 4: Map of the India-Nepal-China Buffer System ${ }^{134}$

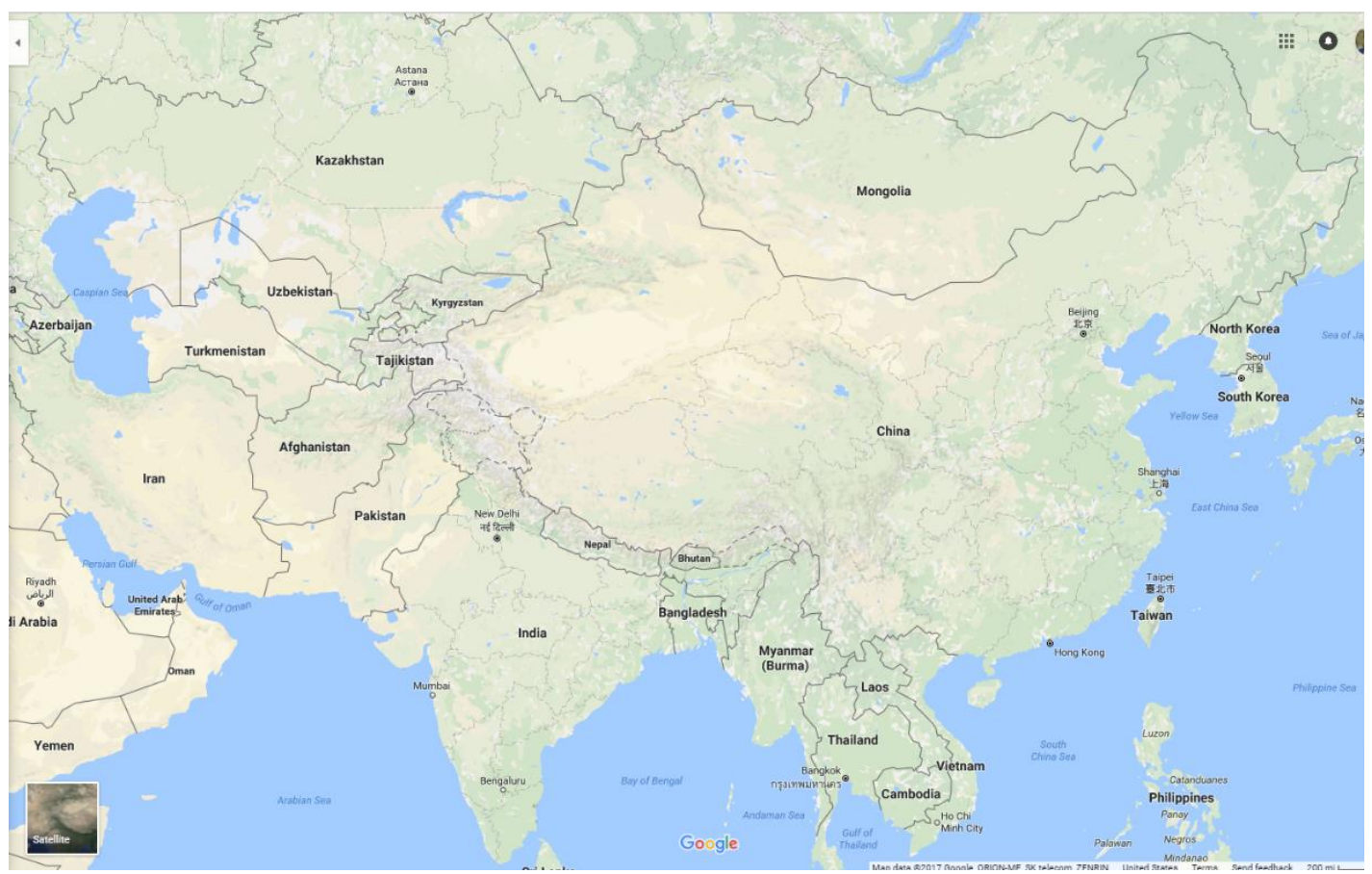

134 Google Maps, 2017, Asia, accessed January 12, 2017,

https://www.google.com/maps/place/Asia/@30.136028,74.6637773,4.25z/data=!4m5!3m4!1s0x3663f18a2 4cbe857:0xa9416bfcd3a0f459!8m2!3d34.047863!4d100.6196553. 


\section{Methodology}

The proposed research design will be mixed method, incorporating elements of qualitative and quantitative analyses. As Creswell and Clark (2011) posit, mixed methodology's "central premise is that the use of quantitative and qualitative approaches, in combination, provides a better understanding of research problems than either approach alone."135 Both types of collected data, when analyzed together, contribute to better understanding of the research problem. The rationale for using a mixed methodology rests on complementarity as well as efforts to elaborate, enhance, illustrate, and clarify results from one method with the results from the other method. ${ }^{136}$ A mixed methodology allows the inclusion of multiple perspectives or more complete understandings of a research problem; it helps in explaining quantitative data, which may not make sense when analyzed as a standalone. ${ }^{137}$ Addressing the changing relevance of buffer states requires qualitative work - the rhetoric utilized by the buffered states while addressing their neighboring states as well as joint agreements signed by the buffered states with the buffer and foreign policy statements of all states in the buffer system need to be analyzed to understand the changes in their relations. This aspect of the mixed-methodology is henceforth titled Rhetorical Engagement.

Apart from the Rhetorical Engagement aspect of the design, there needs to be substantiation of the rhetoric emanating from the buffered states. To capture the manifestation of such rhetoric in the buffer system, particularly in regard to the political

\footnotetext{
${ }^{135}$ Creswell and Clark, Designing and Conducting Mixed Methods Research, 5.

${ }^{136}$ Ibid., 62.

137 John W Creswell, "Steps in Conducting a Scholarly Mixed Methods Study," in DBER Speaker Series, 2013, 54, http://digitalcommons.unl.edu/dberspeakers.
} 
competition within the buffer state, quantitative data was incorporated. Rhetoric itself is an important aspect of diplomacy; nonetheless, its substantiation solidifies commitment. Such reassurance may be in the form of monetary aid or tariff reduction, which greatly increases the stake of the relationship. Quantitative data is essential in ascertaining the increase/decrease in intensity of sub-systemic interactions in the buffer system. The quantitative data collection and analysis portion of this mixed-methodology is part of the Material Engagement aspect in the buffer system. The reinvigoration of competition and the emergence of the buffer state as a competitive political space does not occur in a vacuum; the rhetoric as well as ideational contextualization (Rhetorical Engagement) occurs simultaneously or before/after Material Engagement in the buffer state. In essence, a mixed methodology would allow for the comprehensive study of qualitative rhetorical analysis of Rhetorical Engagement supported by tangible quantitative data of Material Engagement; it helps in the explanation of how the buffered states use both material and rhetorical means to interact with the buffer state.

The mixed method design best suited for the proposed research problem is the convergent parallel design. It requires concurrent collection of quantitative and qualitative data. Both data sets are analyzed independently followed by a combined interpretation. ${ }^{138}$ Quantitative and qualitative data are collected together and then analyzed separately; then, the analyzed data are related and compared, followed by a collective interpretation. ${ }^{139}$ The comparing and relating process is called Convergence/Divergence, which requires both

\footnotetext{
${ }^{138}$ Creswell and Clark, Designing and Conducting Mixed Methods Research, 69-71. ${ }^{139}$ Ibid.
} 
data sets to be compared, contrasted, and synthesized. Finally, the Interpretation will include the summarization and interpretation of the separate results in a combined form; it will include discussions on the extent of convergence and divergence of the two data analyses; the rationale for a combined interpretation is to produce a more complete understanding of the research problem. ${ }^{140}$

The mixed-method approach in the form of a convergent parallel design fits this study as the rhetoric (qualitative data/Rhetorical Engagement) might not always match externalizations (quantitative data/Material Engagement); while officially addressing harmony, the buffered states could possibly engage in competition in the buffer state or vice-versa. In another case, the official rhetoric might concur with operationalization of power in the buffer state. Thus, the convergent parallel design would help account for rhetorical and material trajectories, while also providing a more complete set of tools for interpretation. Figure 5 showcases the process of the convergent parallel design.

${ }^{140}$ Creswell and Clark, Designing and Conducting Mixed Methods Research, 79. 
Figure 5: The Convergent Parallel Design ${ }^{141}$

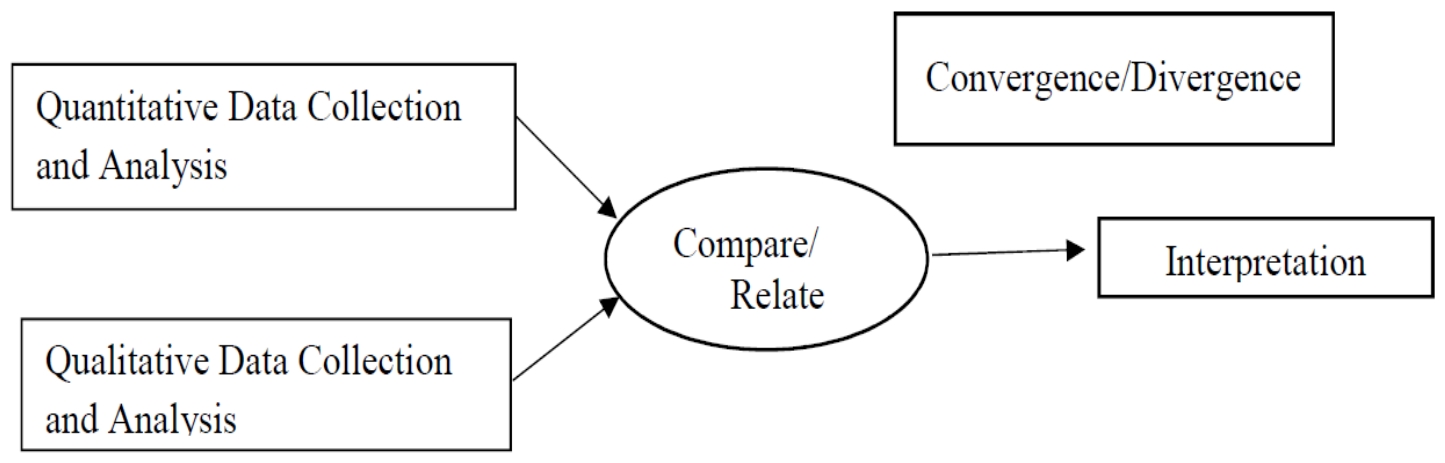

The purpose of the convergent parallel design rests on acquiring different but complementary data, ${ }^{142}$ an exercise that is central in tracing and explaining the changing role of buffer states. The qualitative data will allow the extrapolation of rhetoric associated with sub-systemic power dynamics and how changes in such dynamics increase or decrease the relevance of buffer states. Using the case study, the Sino-Indian dynamics is analyzed through the major critical junctures and how they influence the role of Nepal as a buffer state. Such critical junctures are "events that set processes of institutional/policy change in motion." ${ }^{143}$ Such critical junctures consist of "a crisis, ideational change, and radical policy change." ${ }^{144}$ In essence, critical junctures are set points in historical trajectories that set into motion changes in policies. Within the context of this dissertation, critical junctures denote

${ }^{141}$ Creswell and Clark, Designing and Conducting Mixed Methods Research, 69.

142 Ibid., 77.

${ }^{143}$ Donnelly, Paul and Hogan, John. "Understanding Policy Change Using a Critical Junctures Theory in Comparative Context: The Case of Ireland and Sweden." Policy Studies Journal 40, no.2 (2012)" 324.

${ }^{144}$ Hogan, John, and David Doyle. 2007. "The Importance of Ideas: An A Priori Critical Juncture Framework.” Canadian Journal of Political Science 40, no.4 (2007): 324. 
historical events that are used to assess changes in foreign policy behavior of the three states that consist of the India-Nepal-China buffer system. These critical junctures are used to usually denote higher levels of strategic concern for the buffered states due to developments in the buffer state. In essence, critical junctures signal points of time that entails increased strategic relevance of the buffer states for its neighbors. Such junctures are characterized by shifts in policies of the buffered states towards the buffer state.

Given the limitation of space and time, the period between $1990^{145}$ to 2017 will be analyzed in the dissertation. The aim is to collect qualitative and quantitate data (elaborated in the succeeding sections) regarding Sino-Indian relations and their impact on Nepal's precarious positioning as a buffer state. It seeks to take into account major events in the regional security environment, centering on the buffer state and whether these events had any impact on the buffer role of Nepal i.e. how the buffered states reacted to these subsystemic dynamics that had major implications for the buffer state. Table $1^{146}$ highlights these important critical junctures in Nepal that have implications for the ICNBS.

The years between 1990 to 2007 are characterized by highs and lows in Sino-Indian relations but with immense domestic implications within Nepal. The year 1990 marked the beginning of a constitutional monarchy in Nepal. The liberalization of political space introduced a new set of institutions of governance, including new political actors. ${ }^{147}$ Thus,

\footnotetext{
${ }^{145}$ The year 1990 is chosen as the starting point as it is the year Nepal became a multiparty democracy with a constitutional monarchy. The democratization of political space also allowed the emergence of a more transparent polity, allowing the push and pull factors in foreign policy to be more transparent.

${ }^{146}$ Refer to page number 80 for Table 1.

147 John W Creswell, "Steps in Conducting a Scholarly Mixed Methods Study," in DBER Speaker Series, 2013, 54, http://digitalcommons.unl.edu/dberspeakers;
} 
the years between 1990 to 2007 are heavily focused on domestic political developments in Nepal; given the changes in political configurations within the country, implications for the INCBS are immense. The King of Nepal was traditionally seen as a "balancer" of Chinese and Indian influences in the country, having repeatedly sought Chinese support as a strategy against Indian influence. On the contrary, domestic political parties during this era were backed by New Delhi. Democratization was largely seen as a victory for Indian influence in the country, with immense implications for the precarious INCBS.

The year 2008 marked the year that led to intensification of Chinese interest in Nepal, a development associated with the riots in the Tibetan Autonomous Region (TAR). ${ }^{148}$ Thus, 2008 is the milestone year that marked an increase in Chinese interests in South Asia and China's attempts at wooing states that were traditionally considered within the sphere of influence of India; the new adventurism of Beijing in South Asia can be traced to China's increased power capability. Coupled with increased Chinese interests, the year 2008 marked the shift of Nepal's political status from a kingdom to a secular republic. ${ }^{149}$

Political control of the government shifted from the monarch to popularly elected representatives of political parties;

148 Jeffrey Reeves, “China’s Self-Defeating Tactics in Nepal," Contemporary South Asia 20, no. 4 (2012): 526-27;

Reeves discusses several arguments regarding the strategic value of Nepal for the People's Republic of China (PRC). The first one rests on Nepal's historic, cultural, and economic ties with Tibet; the PRC wants to ensure that Nepal is not used as a base for anti-Chinese efforts. A second perspective promotes the idea that Nepal's importance rests on its ability to serve as a source of economic growth and development in the TAR; Nepal could serve as a transit economy between TAR and the rest of South Asia. A third line of thinking links Nepal's untapped hydroelectricity potential with the prospects for TAR based companies to invest in the country. Finally, Nepal's role as a buffer prevents India from fostering anti-PRC forces in the TAR and as such, holds immense strategic value for China.

Building in Nepal." 215;

In 2008, the first Constituent Assembly of Nepal abolished the monarchy, formally ending the rule of the Shah dynasty and the monarchical tradition in the country. 
Extended details on the periodization and the historical critical junctures are provided in Chapter IV.

In the convergent parallel design, the quantitative data showcases whether the qualitative rhetoric is coupled with tangible approaches used by the buffered states (India and China) in the buffer state (Nepal). This section covers how the critical junctures, explained as part of the qualitative data collection, appears in regard to actual policy outcomes; as part of the quantitative analysis, this section includes the three socioeconomic indicators: trade, foreign direct investment, and foreign aid. Analyzing the quantitative aspect of the sub-systemic dynamics showcases how the qualitative rhetoric of changes in sub-systemic dynamics plays out in the buffer state. It seeks to decipher the manner in which increase/decrease of sub-systemic rivalry plays out in the buffer through tangible indicators.

Overall, this mixed method study addresses the relevance of buffer states by connecting the concept to changing sub-systemic power capabilities; changes in regional power capabilities have implications for changing roles of buffer states, from one-sided buffers to highly competitive political spaces for the buffered states. Through the singlecase study of the buffer system consisting of Nepal, India and China, this study examines Nepal's continued but changing role as a buffer between larger powers. A convergent parallel design is utilized to analyze the rhetoric of political leaders as well as governments of the states under study through qualitative data collection; concurrently, quantitative data is analyzed to discern the physical manifestations of the rhetoric used, including whether there is increased competition in the buffer state. Further details on the type of qualitative and quantitative data collection are discussed in the following sections. 
Table 1: Historical Critical Junctures in Triadic Relations between India, China, and Nepal

\begin{tabular}{|l|l|}
\hline Date & Event \\
\hline 1990 & Democratization of Nepal \\
\hline 2001 & Nepalese Royal Family Massacre \\
\hline 2005 & Suspension of Parliamentary Democracy in Nepal \\
\hline 2008 & Riots in the Tibetan Autonomous Region \\
\cline { 2 - 2 } & End of the Nepalese Monarchy \\
\hline \multirow{2}{*}{2015} & The Nepal Earthquakes \\
\cline { 2 - 2 } & Blockade of Nepal \\
\hline 2017 & Nepal's Entry into China's Belt \& Road Initiative \\
\hline
\end{tabular}

\section{Quantitative Data Collection and Analysis}

Quantitative data collection also covered the time frame between 1990 to the present. Three indicators were compared to ascertain how Sino-Indian competition in Nepal plays out: trade (export and import figures in USD), Foreign Direct Investment (FDI), and foreign aid. These are contextualized as tools for influencing the buffer state and are used to decipher whether the relevance of the buffer state (i.e. Nepal) is heightened; intensified competition with regards to the four aforementioned indicators showcase heightened relevance of the buffer state for the buffered states. The data for the five indicators were collected for the following years: 1989, 1990, 1991, 2000, 2001, 2002, 2004, 2005, 2006, 2007, 2008, 2009, 2014, 2015, 2016, and 2017. These years are based on the historic critical junctures; it includes the years of these junctures as well as a year before and after them. This data collection allows the deciphering of whether there were substantial changes during critical junctures when compared with the pre- and post- critical juncture periods. The before and after dates are included to decipher whether the critical junctures saw spike/dip in the four indicators chosen. 
The usage of quantitative data rests on the parallel convergent design of this proposed research; it seeks to ascertain whether changes in rhetoric (when they do take place) during or after critical junctures are supported by tangible support from the buffered states. The three indicators utilized as part of the quantitative data collection are used to analyze how Sino-Indian competition plays out in Nepal's role as a buffer - do critical junctures lead to increase/decrease in these indicators? How do these changes in the usage of material tools relate to the rhetoric analyzed under the qualitative section of this research? The usage of these indicators aids in answering such questions directly connected to the research question. Changing patterns in material and rhetorical relations during critical periods and a comparison of the before/after levels of these indicators at critical junctures help in explaining the dynamic nature of the buffer system. In addition, it also aids in showcasing how changes in power capabilities, could allow the buffered states to exert more influence in the buffer state against their contender.

To analyze the quantitative data, the Kruskal-Wallis Test was carried out to measure the variance in means between the pre-, during, and post- critical juncture period for the three dependent variables chosen. The Kruskal-Wallis Test is chosen to assess the variance of trade, FDI, and aid, in the pre-, during, and post-critical juncture years. SPSS 22 is used for the quantitative analyses. This Test is the most suited quantitative test for the study as it is a non-parametric test suitable for testing statistical significance between two or more groups of an independent variable (pre-, during, and post-critical juncture periods) on a continuous dependent variable. For example, the Kruskal-Wallis Test operates using variances in mean figures for trade between Nepal-China and Nepal-India to find statistical significance in the pre-, during, and post- critical juncture periods. Here, the independent 
variable (IV) is sub-systemic rivalry and the dependent variable is the buffer state's political relevance beyond just a geographical discontinuity, expressed in the form of trade, foreign direct investment, and foreign aid. Furthermore, due to the limited quantitative data used for this study, the Kruskal-Wallis Test (KWT) is the best suited nonparametric alternative to the one-way Analysis of Variance (ANOVA) that measures statistical significance between two or more independent groups.

For the purpose of the study, the Independent Variable (IV) is divided into three groups: pre-, during, and post-critical juncture. These are categorical designations coded accordingly (for example, pre-critical juncture as 1 ; during critical juncture as 2 ; and postcritical juncture as 3). The Dependent Variables (CV) include trade, FDI, and foreign aid, i.e. these three variables are dependent on the increase/decrease of sub-systemic rivalry (IV). As for the qualitative data, the DV is based on the total number of official statements from India and China regarding Nepal and the themes of positive and negative affirmations. ${ }^{150}$ For example, if the critical juncture for 2008 is chosen, the KWT is carried out to assess the DV in the pre-, during, and post-periods of the critical junctures. The KWT aids in deciphering whether critical junctures impact the increase/decrease in intensification of buffered state interactions in the buffer state through quantitative analysis. Because critical junctures are points of contention in the buffer system, they are considered to be periods of increased sub-systemic rivalry. Additionally,

Non-parametric correlations are carried out in conjunction with the KWT to assess the trajectories of the dependent variables. These correlations allow the assessment of

${ }^{150}$ Refer to page 93 for more on the dictionaries titled positive and negative affirmations. 
overall changes in the material engagement of India and China with Nepal over time. In essence, the correlations were conducted to further assess increase or decrease in trade (exports and imports), foreign direct investment (FDI), and foreign aid over time (pre-, during, and post- critical juncture).

Based on the discussions of the variables, the overarching hypothesis of the dissertation is as follows:

H1: If sub-systemic rivalries among Middle or Great powers envelop a small, buffer state, then this rivalry will recover the buffer state's political relevance beyond a simple geographical discontinuity among rivalrous powers.

Based on the specification of the variables, the following hypotheses are tested:

H2: At critical junctures, trade figures will intensify between Nepal-India and Nepal-China due to increase in sub-systemic rivalry.

H3: At critical junctures, FDI figures will intensify between Nepal-India and Nepal-China due to increase in sub-systemic rivalry.

H4: At critical junctures, foreign aid figures will intensify between Nepal-India and NepalChina due to increase in sub-systemic rivalry. 
H5: At critical junctures, rhetorical engagement will intensify between Nepal-India and Nepal-China due to increase in sub-systemic rivalry.

The hypotheses are formulated based on the assumption that critical juncture points are periods of critical importance for the buffered states i.e. India and China; as such, there will be intensification in both material and rhetorical engagement between Nepal and its two neighbors. Here, intensification could mean increase or decrease, as these years can also be points of lull in relations. Also, the dependent variables used in this study showcase that the tools used by the buffered states are beyond the conceptualization of the buffer as a geographic discontinuity. They are included to showcase that buffer states' political relevance is beyond just a geographic discontinuity; that interactions of Middle/Great Powers in the buffer states showcase dynamic interactions using both material and rhetorical tools.

\section{Qualitative Data Collection and Analysis}

The collection of qualitative data between 1990 to 2017 rests on major events during this time frame, presented as critical junctures in the buffer system. Table $1^{151}$ illustrates the major critical junctures in each period, with implications for sub-systemic dynamics between India and China. It includes events that had severe implications for the internal political predicament of Nepal. Events of domestic political change include changes in dynamics of Nepal's relations with its two neighbors. As such, these events as

\footnotetext{
${ }^{151}$ Refer to page number 80 for Table 1.
} 
included in the list as Nepal has attempted to balance its neighbors or sought to tilt to one neighbor during such critical junctures. In essence, these critical junctures are chosen based on their importance to Sino-Indian interactions pertaining to Nepal. While the riots in the TAR did not occur in Nepal, the event had implications for political interactions between India and China. The domestic security upheaval in the PRC had direct implications for its foreign policy towards Nepal. Beijing took a more strident stance regarding the activities of Tibetan refugees in Nepal after the event. ${ }^{152}$ Thus, this event is an exception as a critical juncture, because it occurred outside of Nepal, but had implications for it within the larger context of Sino-Indian interactions.

The emergence of a Sino-Indian competition can be traced back to the incorporation of Tibet into the People's Republic of China, an act that was highly resented by India. Apart from the 2001 Nepalese Royal family massacre, all other events have involved a shuffling of power capabilities (or perceptions thereof) at the regional level. The qualitative data collection focuses on these major critical junctions as points of inference - it seeks to analyze whether these events with sub-systemic implications led to increase/decrease in rhetoric from India and China towards Nepal. Furthermore, these rhetorical statements are evaluated to decipher patterns of change. These changes are analyzed based on whether there were rhetorical differences in the pre-, during, and post- periods emanating from India and China.

Qualitative data were collected for the following: intergovernmental agreements, joint/unilateral foreign policy statements, official press releases, media briefings, and

152 Bibek Chand and Lukas Danner, "Implications of the Dragon's Rise for South Asia: Assessing China’s Nepal Policy,” Strategic Analysis, 40 (1): pp. 31-32. 
memoranda of understanding (MoUs). The data points used include the critical junctures and a year before and after the critical juncture; the before and after years are included to showcase whether there are changes (increase or decrease) in the three data sets collected as part of the qualitative data analysis. The three time periods are included to ascertain whether or not there have been any changes during the critical junctures. These analyses were supplemented by archival data wherever possible. In the context of this research, documents including treaties, press releases, and foreign policy statements ${ }^{153}$ were considered for qualitative analysis. Such data helped to decipher the dynamic triadic relations as well as whether there had been changes in rhetoric, especially during the critical junctures presented in Table 1. The qualitative data collected were analyzed using the process of content analysis. NVivo 11 is used as the tool for the qualitative research analysis. This part of the mixed method will focus on the rhetorical engagement aspect of the buffer system.

Joint intergovernmental agreements include bilateral cooperation on any field pertaining to China-Nepal and India-Nepal relations. While not all bilateral agreements are put into action, they signal rhetorical affirmation of closer ties or the attempt to bolster bilateral ties. These joint agreements were collected from the respective departments of the countries that deal with foreign affairs. Joint agreements included a wide variety of bilateral issue areas such as trade or security. This variable only accounted for official joint

153 Treaties, newspaper articles, and foreign policy statements pertaining to Sino-Indian, SinoNepalese, Indo-Nepalese, as well as the trilateral nexus of India-Nepal-China are included, given that dynamics of Sino-Indian relations largely define their role in Nepal. Although most treaties and newspaper articles pertaining to the aforementioned dynamics are available online, access to older foreign ministry and embassy statements are supplemented by archival work. 
statements/agreements that the Government of Nepal has signed with the Governments of India and China that are made available to the public.

Foreign policy statements include rhetorical reaffirmation of bilateral ties, including the position of a state regarding developments in another state. Thus, foreign policy statements included public position paper of a government regarding another county. Furthermore, such statements included declarations of policy change (explicit or implicit). This variable for the dissertation entailed foreign policy statements issued by India and China regarding Nepal during the critical juncture years presented in Table 1. Additional materials such as media briefings and statements from official spokespeople as made available via the official websites of China and India on their relations with Nepal were also included for the qualitative analysis part of the convergent parallel design.

Once the qualitative data was collected, content analysis was carried out using NVivo 11. Content analysis is "the systematic, objective, quantitative analysis of message characteristics." 154 Broadly, it is a method where the content of the message forms the basis for drawing inferences and conclusions about the content. ${ }^{155}$ The content analysis aided in analyzing whether there were trends in the qualitative data collected, including the intensification of rhetoric based on the timeframe of Table 1. The increase or decrease in the interest of China and India were operationalized based on several variables explained below. NVivo 11 aided in deciphering general trends in rhetoric as well, categorizing them based on whether or not they signaled a change in the significance of the buffer state in

${ }^{154}$ Kimberly A. Neuendorf, The Content Analysis Guidebook, 2nd ed. (Thousand Oaks, CA: SAGE Publications, Inc., 2017), 1.

155 David Nachmias and Chava Nachmias, "Content Analysis," in Research Methods in the Social Sciences (UK: Edward Arnold, 1976), 132-39.. 
relation to the critical junctures. As such, the qualitative analysis carried out using NVivo 11 complemented the quantitative analysis by providing rhetorical affirmation or invalidation of the change in the role of the buffer. For this dissertation, Kimberly A. Neuendorf's typification of content analysis research that is included in her book titled The Content Analysis Guidebook was used. Figure 6 showcases Neuendorf's approach to content analysis. 
Figure 6: Neuendorf's Approach to Content Analysis ${ }^{156}$

1. Theory and rationale: What content will be examined, and why? Are there certain theories or perspectives that indicate that this particular message content is important to study? Library and online work is needed here to conduct a good literature review. Will you be using an integrative model, linking content analysis with other data to show relationships with source or receiver characteristics? Do you have research questions? Hypotheses?

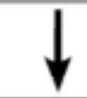

2. Conceptualizations: What variables will be used in the study, and how do you define them conceptually (i.e., with dictionary-type definitions)? Remember, you are the boss! There are many ways to define a given construct, and there is no single right way. You may want to screen examples of the content you're going to analyze to make sure you've covered everything you want to cover.

\section{$\downarrow$}

3. Operationalizations (measures): Your measures should match your conceptualizations (this is called internal validity). What unit of data collection will you use? You may have more than one unit (e.g., a by-utterance coding scheme and a by-speaker coding scheme). Are the variables measured well (i.e., at a high level of measurement, with categories that are exhaustive and mutually exclusive)? An a priori coding scheme describing all measures must be created. Both face validity and content validity may also be assessed at this point.
a. Human Coding
b. CATA
(Computer-
Aided Text
Analysis)

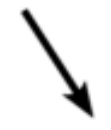

4a. Coding schemes. You need to create the following materials:

1. Codebook (with all variable measures fully explained)

2. Coding form 4b. Coding schemes. With CATA, you still need a codebook of sorts-a full explanation of your dictionaries and methods for applying them. You may use internal dictionaries (e.g., those provided in Pennebaker, Booth, and Francis's program, Linguistic Inquiry and Word Count [LIWC]) or originally created, custom dictionaries). When creating custom dictionaries, it's typical to generate a frequencies list from your text sample and examine for key words and phrases.

${ }^{156}$ Neuendorf, The Content Analysis Guidebook, 40-41. 


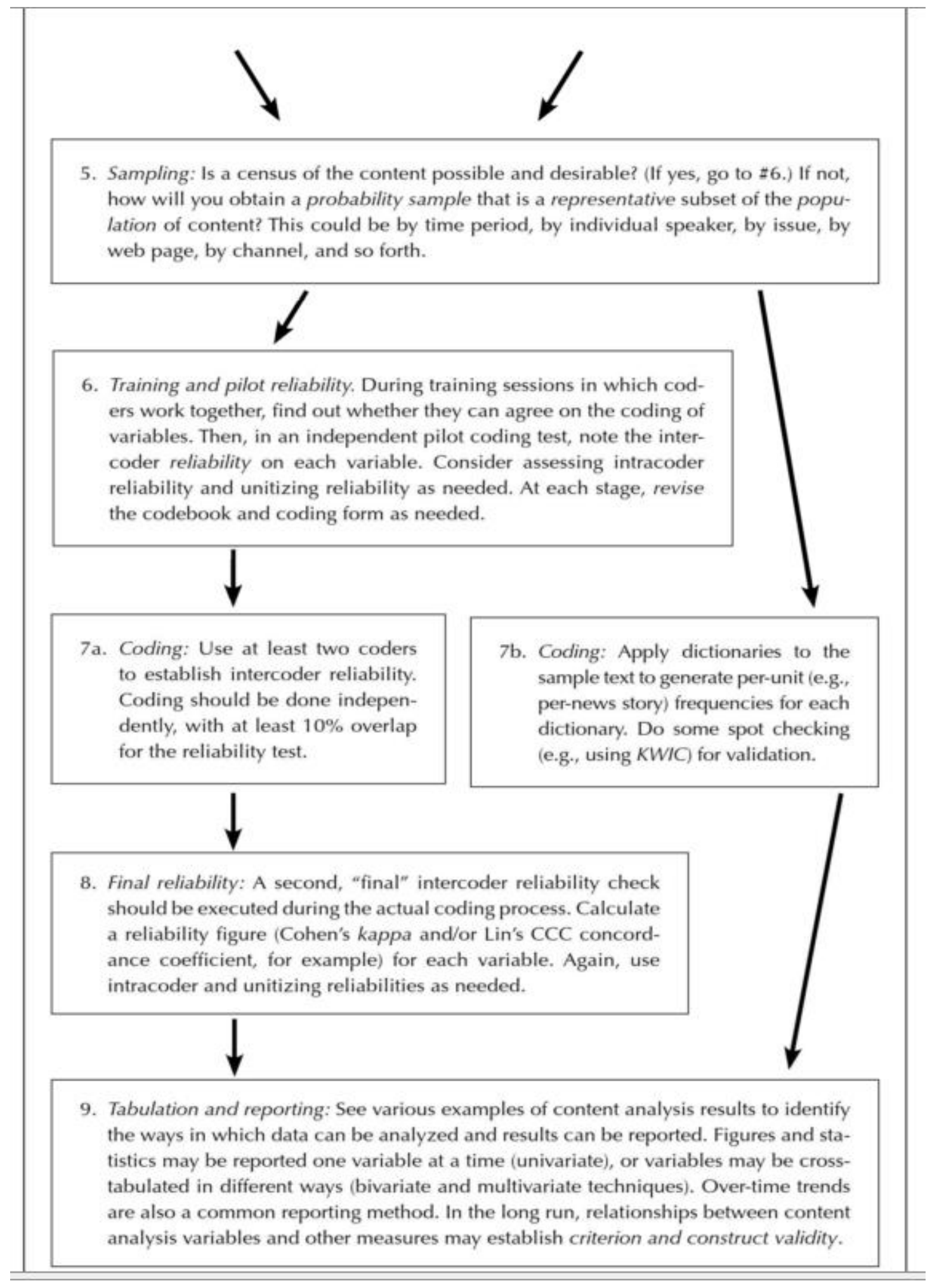


Neuendorf's approach to content analysis provides a step-by-step process to carry out content analysis. The rationale for the conduct of this study and the theoretical framework are discussed in prior chapters. The next step entails conceptualization, which was already discussed in the form of the research question and the hypothesis.

Content analysis is the qualitative aspect of the mixed-method research design used for this dissertation. As the qualitative analysis seeks to analyze the intensity of subsystemic competition, the operationalization of the variables was based on the independent variable: the sub-systemic rivalry between China and India. The study is based on the logic that at critical junctures that are chosen, the competition intensifies and perhaps, leads to increases in the immediate aftermath. Thus, the increase or decrease in intensity of subsystemic interaction in Nepal are operationalized.

Increase in intensity:

Increase in the overall number of the measures from India and China included in the qualitative analysis. Increase in intensity of sub-systemic rivalry can include both positive and negative affirmations. ${ }^{157}$

Decrease in intensity:

Decrease in the overall number of the measures from India and China included in the qualitative analysis. Decrease in intensity of sub-systemic rivalry can include both positive and negative affirmations.

${ }^{157}$ Negative and positive affirmations are discussed on page 93. 
To accurately capture the increase or decrease in rhetorical intensity of subsystemic rivalry, two custom dictionaries are created using NVivo 11. A custom dictionary is "a set of words, phrases, parts of speech, or other word-based indicators constructed by the researcher to be used for search of texts." ${ }^{158}$ While the total number of qualitative artefacts may signal the increase or decrease in the intensity of relations, it is pertinent to analyze whether it was positive or negative to assess if an increase in positive Indo-Nepali reports is coupled with an increase in negative Sino-Nepali reports and vice-versa. To assess whether an increase in positive interactions between India and Nepal was accompanied by any lull in China-Nepal relations and vice-versa, two separate dictionaries were created. The two dictionaries were used to decipher how interactions between NepalIndia and Nepal-China are presented in pre, during, and post-critical juncture periods.

The first dictionary, called "positive affirmation," focuses on the theme of positive bilateral relations; it is used to decipher if there is an increase/decrease in positive reports on Nepal-India and Nepal-China relations before (pre), during, and after (post) the critical junctures. It includes the following set of words and phrases, which are further explained in the qualitative data analysis section of Chapter V:

${ }^{158}$ Neuendorf, The Content Analysis Guidebook, 148-49. 
Positive affirmation: ${ }^{159}$

$\begin{array}{llll}\text { coop* } & \text { agree* } & \text { friend* } & \text { help* } \\ \text { aid* } & \text { dona* } & \text { "people to people" } & \text { affinity } \\ \text { engag* } & \text { connect* } & \text { assist* } & \text { collaborat* } \\ \text { partner* } & \text { harmony } & \text { recipro* } & \text { alliance } \\ \text { ally } & & & \end{array}$

As for negative affirmation, the focus is on rhetoric that is perceived as negative or critical of the other party. Negative affirmation does not signal the decrease in intensification of relations - it is used to assess whether positive affirmation in one dyadic relation (say Nepal-India) is coupled by increased negative affirmation in the other dyadic relation (say Nepal-China). This adds nuance to the usage of qualitative analysis and helps to explain the nature of official rhetoric. The dictionary for negative affirmation includes the following words and phrases:

Negative affirmation:

$\begin{array}{llll}\text { critic* } & \text { condemn* } & \text { cancel* } & \text { disapprov* } \\ \text { rebuk* } & \text { reprehen* } & \text { denounc* } & \text { castigat* } \\ \text { autocrat* } & \text { "oppose" } & \text { disappoint* } & \text { rebuttal } \\ \text { "human rights abuse" } & \text { "deeply concerned" } & \text { "gravely concerned" } & \text { decry } \\ \text { sanction* } & & & \end{array}$

$159 *$ signifies iterations of the root word. For example, the word dona* in the dictionary includes numerous possible iterations of the base "dona" including donations, donated, donating, and donate. 
These two dictionaries were applied through the Text Search Query in NVivo 11, which helped in deciphering whether the rhetorical statements used for the dissertation were positive or negative in their disposition. To complement the qualitative analysis, the Word Count Query was also run on NVivo 11. This Query assessed the top five themes in rhetorical statements in the pre-, during, and post-critical juncture periods.

The sampling for the qualitative aspect of the convergent parallel design, is the buffer system of India-Nepal-China. The within case study uses the timeline of 1990-2017 to assess the historical critical junctures highlighted in Table 1 . The sampling consists of foreign policy statements, press briefings, official news from the respective Ministries and Embassies, and joint agreements. These are discussed in detail in Chapter V.

The sampling set was assessed using the two custom dictionaries - positive affirmation and negative affirmation. Word frequency tests were also carried out to decipher if there was an increase or decrease in rhetorical engagement in the three time frames chosen for this study. The results are reported in Chapter V. They are discussed in Chapter VI in conjunction with the results of the quantitative analysis. Both analyses are discussed and interpreted together as part of the conjunction of both methodologies through Convergence/Divergence.

Overall, the research design for the dissertation is a mixed-method approach that includes quantitative analysis in the form of the Kruskal-Wallis Test for the three chosen dependent variables. The qualitative aspect of the research design includes the conduct of content analysis using NVivo on the qualitative data that is collected. When both analyses are carried out, the results are first organized in Chapter V, along with; Chapter VI includes the individual analysis of the quantitative and qualitative results. It will also include the 
convergent discussion of both analyses and their collective interpretation. Figure 7 showcases the pictorial depiction of the convergent parallel design used for the analysis of the INCBS in this dissertation.

Figure 7: Convergent Parallel Design used for the India-Nepal-China Buffer System

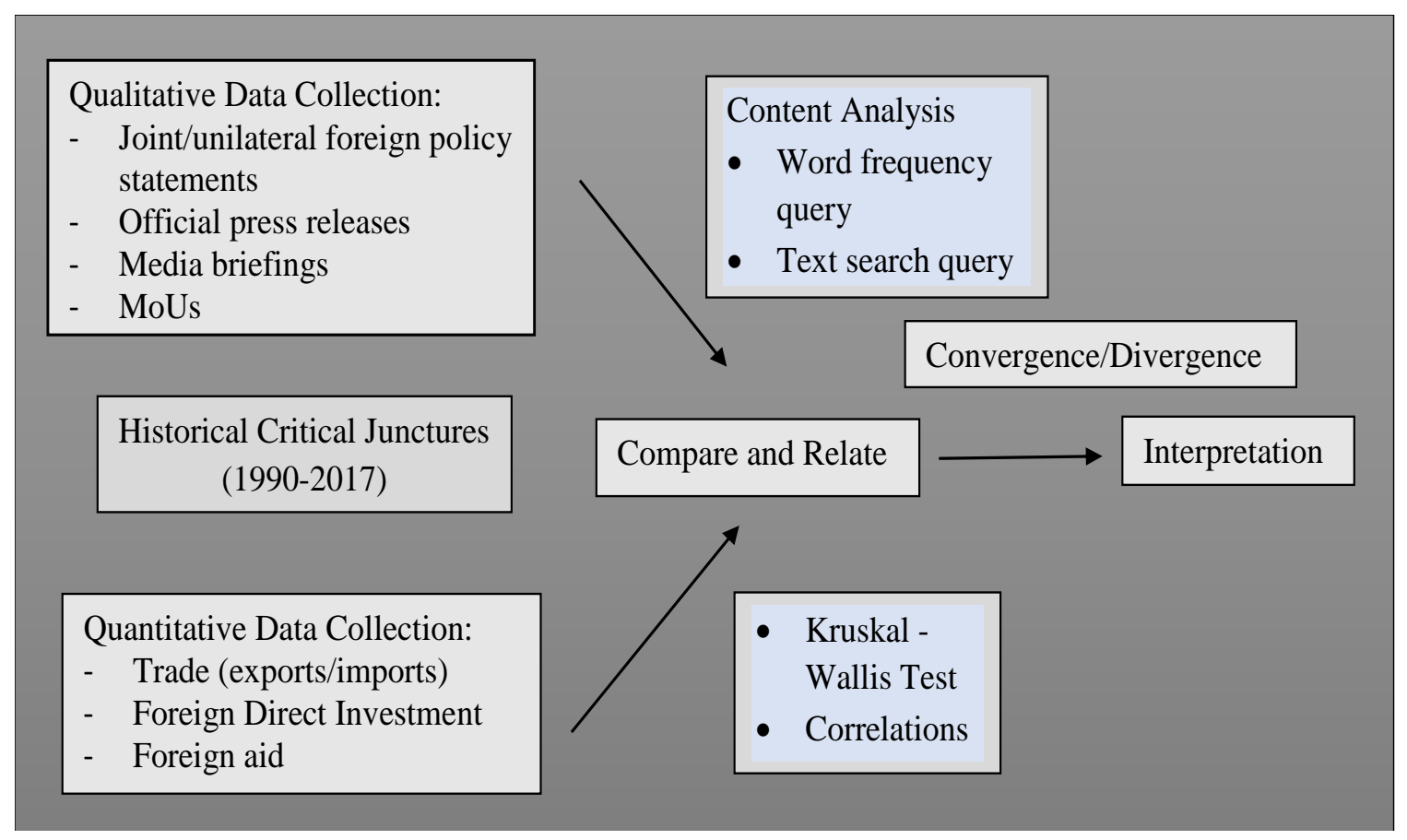




\section{CHAPTER IV: CRITICAL JUNCTURES IN THE INDIA-NEPAL-CHINA BUFFER SYSTEM}

The study of critical junctures is an ongoing academic endeavor with many contextual definitions and uses. One of the earliest uses of the concept was by David Collier, who defined it as "(1) a major episode of institutional innovation, (2) occurring in distinct ways, (3) and generating an enduring legacy." 160 Historical critical junctures are "events that set processes of institutional/policy change in motion."161 They are points within a timeframe which lead to changes in policies or strategies. A critical juncture usually consists of a "crisis, ideational change, and radical policy change."162 Such crisis situations lead to the creation of contexts where "change agents contest extant ideas and the policies based upon them."163 Figure $8^{164}$ depicts Donnelly and Hogan's conception of critical junctures, which is the base model for the modified conception of the critical junctures used for this dissertation.

Another perspective considers critical junctures as "choice points when a particular option is adopted from among two or more alternatives. These junctures are 'critical' because once an option is chosen, it becomes progressively more difficult to return to the

${ }^{160}$ David Nachmias and Chava Nachmias, "Content Analysis," in Research Methods in the Social Sciences (UK: Edward Arnold, 1976), 132-39.

161 Donnelly and Hogan, "Understanding Policy Change," 324; David Nachmias and Chava Nachmias, "Content Analysis," in Research Methods in the Social Sciences (UK: Edward Arnold, 1976), 132-39.

$$
\begin{aligned}
& { }^{162} \text { Ibid., } 324 . \\
& { }^{163} \text { Ibid., } 325 . \\
& { }^{164} \text { Refer to page number } 99 .
\end{aligned}
$$


initial point when multiple alternatives were still available." 165 The logic behind the critical juncture concept rests on the idea that any shocks or aberrations in the system, directly or indirectly, lead to changes in policies or strategies. Such critical junctures are points in historical trajectories wherein states are faced with critical policy choices. In essence, policy change remains an inherent part of these definitions as institutions are impacted by critical junctures.

Critical junctures tie into the hypothesis of the dissertation, wherein the level of strategic rivalry dictates the increased or decreased strategic value of the buffer state. Additionally, critical junctures aid in understanding whether there are differences in material and rhetorical changes before and after these junctures, which are reflective of the interests of the buffered states vis-à-vis policy changes towards the buffer state. The critical juncture concept is particularly applicable in buffer systems as the buffered states engage in dynamic political interactions. As the buffer state is a highly contested geopolitical space, frequent strategic calculations are pertinent to ensure the other buffered state does not have an upper hand.

In the context of this dissertation, critical junctures are operationalized as policy choice points in the timeline of the buffer system. The buffer system is highly dynamic and as such, using the institutional change approach will require a focus on a long-time frame, which is beyond the scope of this paper. Thus, the critical junctures in this dissertation are timepoints in history that are characterized by ideational or policy changes, emanating from

165 James Mahoney, The Legacies of Liberalism: Path Dependence and Political Regimes in Central America (Baltimore, MD: Johns Hopkins University Press, 2002). 
the buffered states. These critical junctures include events in the buffer system that had the probability of triggering policy or strategic changes.

A modified version of Donnelly and Hogan's conception of critical junctures as historical points consisting of crisis, ideational change, and radical policy change is used in this dissertation as it is the most prudent conceptual structure to analyze bilateral rivalry of the buffered states and the conundrums of the trilateral buffer system. Figure 9 showcases this modified approach to Donnelly and Hogan's model of critical junctures. For the purpose of this dissertation, radical policy change is altered to just policy changes as any radical changes in the buffer system are highly dangerous and highly unlikely to occur. The focus of such changes is on the buffered states as they are materially more powerful than the buffer state; additionally, it is the buffered states that are in competition in the buffer system. Thus, attention is paid to historical events that had the potential to shift interests or disrupt the "normal state of affairs" within the buffer system.

Table 1 in Chapter III ${ }^{166}$ illustrates the critical junctures chosen for this study. These events between 1990 to 2017 highlight not simply changes within Nepal that warranted attention from its contiguous neighbors India and China. The 2008 riots in the TAR is also included as a critical juncture due to its implications for altering the political dynamics of the buffer system. Specifically, the 2008 riots bolstered China's interest in Nepal, given the country's shard land border with the Tibetan Autonomous Region. Thus, this chapter provides details on the critical junctures chosen for the dissertation with discussions on Nepal's role as a buffer state between China and India.

\footnotetext{
${ }^{166}$ Refer to page number 80 for Table 1.
} 
Figure 8: Donnelly and Hogan's Conception of Critical Junctures

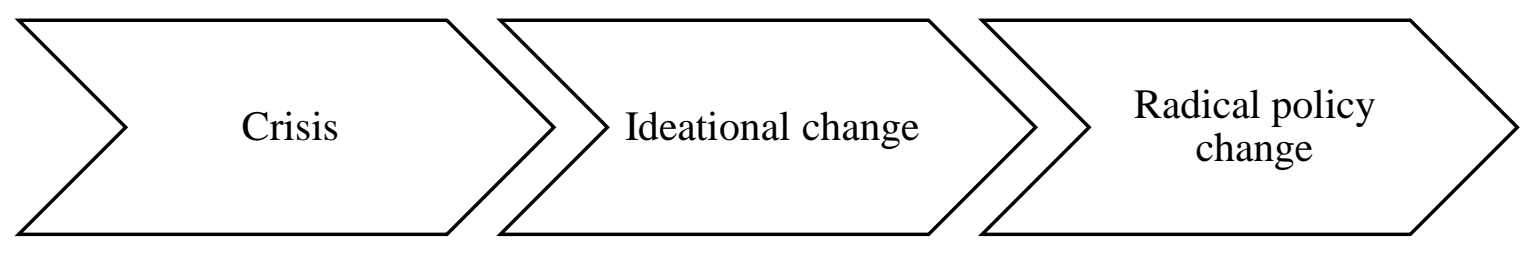

Figure 9: Modified Conception of Critical Junctures

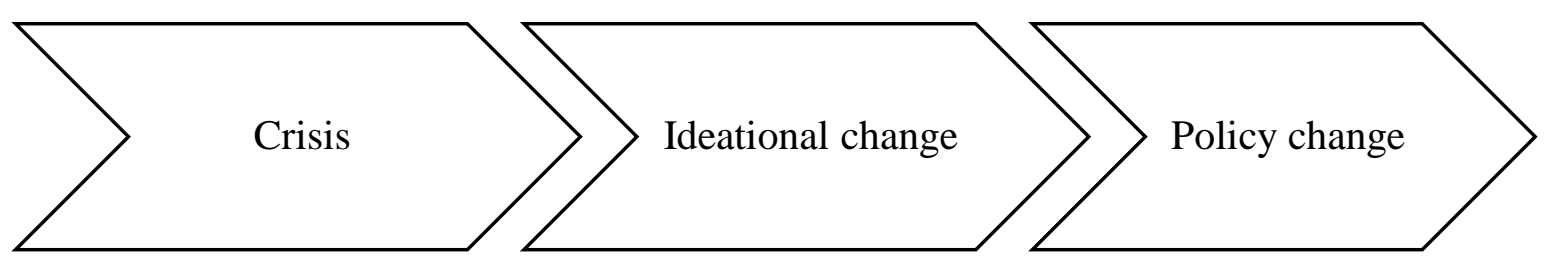

The years between 1990 and 2007 were characterized by internal political upheaval in Nepal. This time period set the stage for Nepal's emergence from centuries of monarchical rule. The democratization process began in 1990, when "Jana Andolan I" or "People's Movement I" forced King Birendra to institute parliamentary democracy with the monarchy as a figurehead. The early years of democratic governance were marred with political infighting and popular discontent. Years of political disenchantment culminated into the emergence of a Maoist rebellion in $1996 .{ }^{167}$ The massacre of King Birendra's family in 2001 followed, which was succeeded by the coronation of his brother, Gyanendra, as the King of Nepal. The new monarch increasingly consolidated power, leading to "Jana Andolan II" or "People's Movement II", which led to the abolishment of the monarchy in 2008 and the emergence of Nepal as a secular republic that same year.

${ }^{167}$ James Mahoney, The Legacies of Liberalism: Path Dependence and Political Regimes in Central America (Baltimore, MD: Johns Hopkins University Press, 2002). 
This section describes in detail the four historical critical junctures between 1990 and 2007, which are chosen for analysis in this dissertation. Each juncture entails domestic political changes occurring in Nepal with implications for its relations with India and China.

\section{Democratization of Nepal}

Long isolated, Nepal opened its borders to the outside world in 1951. Following the end of the autocratic rule of the Rana family, Nepal's first experience with democracy began in the same year. The erstwhile King of Nepal, Tribhuvan, successfully ended the Rana Regime by going to exile in India and only returning after Indian pressures led to the ouster of the Rana Prime Minister. ${ }^{168}$ The new democratic government, headed by the Nepali Congress (NC) Party, was the country's first experience with democratic rule. Lack of institutional support and the absence of democratic political norms gave way to the monarchy under Tribhuvan's son Mahendra usurping power in $1960 .{ }^{169}$ King Mahendra's absolute monarchy, also called the panchayat system, was characterized by the lack of any public space for political parties. The Nepali monarchy, since the time of King Mahendra, had long been considered the institution that checked India's influence in Nepal. The appeal to China as a check against what were considered Indian political interference was even accorded a name - the China Card. This entailed using China as a bulwark against Indian interests in the country. The 1990 Jana Andolan I witnessed Indian pressure on King

\footnotetext{
168 Thapa and Sharma, "From Insurgency to Democracy," 207.

${ }^{169}$ Ibid.
} 
Birendra to hand over power to the political parties, while China refrained from commenting on the domestic developments in Nepal.

After his coronation as the King of Nepal in 1955, Mahendra sought extensive ties with China. ${ }^{170}$ Mahendra bolstered Nepalese nationalism given his country's precarious geopolitical position between two much larger powers. As such, he sought to reduce Nepal's dependence on its traditional partner, India, and increase his country's interactions with China. ${ }^{171}$ Mindful of India's preponderance, Mahendra was careful not to antagonize India. He solidified the concept of "equidistance" in Nepali foreign policy. It manifested itself in Nepal's neutrality during the Tibetan uprising in 1959; Mahendra asserted the following:

"Nepal is a test case as to whether a small country situated between two big countries (India and China) can in the realities of power relations in the mid-twentieth century would preserve its independence, freedom and sovereignty in its own way and manner." ${ }^{172}$

Mahendra's son, King Birendra, ascended to the throne in 1972 after King Mahendra's death. He continued the absolute rule of his father but agreed to hold a national referendum in 1980; the contentious results of the referendum supported the continuation

\footnotetext{
${ }^{170}$ James Mahoney, The Legacies of Liberalism: Path Dependence and Political Regimes in Central America (Baltimore, MD: Johns Hopkins University Press, 2002).

${ }^{171}$ Rama Kant, “Nepal's Foreign Policy and China,” India Quarterly 27, no. 3 (1971): 206.

172 Ibid., 207.
} 
of the partyless panchayat system. ${ }^{173}$ It was only in 1990 that King Mahendra's son Birendra ushered in Nepal's second experience with democracy. Nepal's democratization in 1990 was initiated as a non-violent movement, spearheaded by the Nepali Congress. ${ }^{174}$ The movement, called Jana Andolan I, was called off only after King Birendra's announced the end of the ban on political parties. The King was faced with extensive public pressure, ${ }^{175}$ which led to Nepal's transition from an absolute monarchy under King Birendra to a constitutional monarchy.

The democratization period is essential in understanding Sino-Indian dynamics in Nepal. It was the 1988-89 border blockade by the Indian administration under Rajiv Gandhi that exacerbated democratic aspirations in Nepal. ${ }^{176}$ Additionally, India had long supported democratic forces in Nepal, including one of its oldest political parties - the Nepali Congress. ${ }^{177}$ The Nepalese monarchy, especially King Mahendra, had long sought to check Indian interests in Nepal. However, the initiation of democratic governance under a constitutional monarchy changed the domestic political context within Nepal. India's commitment to democracy in Nepal had long contributed to the monarchy's tumultuous relationship with India. As such, the democratization of Nepal is a critical juncture in the

\footnotetext{
${ }^{173}$ Douglas Heck, "Nepal in 1980: The Year of the Referendum," Asian Survey 21, no.2 (1981): 183.

${ }^{174}$ Padmaja Murthy, "Understanding Nepal Maoists' Demands : Revisiting Events of 1990 ," Strategic Analysis 21, no. 1 (2003): 44.

${ }^{175}$ Jana Andolan (जन आन्दोलन) literally translates to popular movement. It was the first people's movement in Nepal after the suspension of democracy in 1950 by the erstwhile Nepalese monarch King Mahendra.

${ }^{176}$ Hari Bansh Jha, "Nepal's New Tryst with Democracy and the 'India Factor'," Centre for Land Warfare Studies Journal, Winter 2014.

${ }^{177}$ Fritz Tucker, "Jana Andolan: The People's Movement in Nepal," Zeteo: The Journal of Interdisciplinary Writing, Fall (2012): 7.
} 
buffer system as the opening up of political space and the curtailing of power of the monarchy with its pro-China bent, had implications for the country's relations with its two neighbors. The crisis in this instance was the call for democratization of the political space in Nepal. The ideational change was the shift from an absolute monarchy to a constitutional monarchy, which heralded significant democratization in Nepal. The policy changes were largely tied to the shift of power from the monarchy to political parties. The political parties were supported by New Delhi while the monarchy had time and again played the "China Card." As such, the democratization of Nepal was an instance of critical juncture in the India-Nepal-China buffer system as the political parties of Nepal were viewed as more proIndia than the monarchy.

\section{Nepalese Royal Family Massacre}

On June 1 2001, Nepal faced its first major political crisis since the Jana Andolan I of 1990. The erstwhile Crown Prince Dipendra massacred over a dozen members of the royal family, including King Birendra and Queen Aishwarya. King Birendra's brother, Gyanendra, had survived the murderous rampage due to his absence from the weekly dinner during which time the massacre occurred. ${ }^{178}$ As such, Gyanendra was crowned the $13^{\text {th }}$ King of united Nepal. ${ }^{179}$ The backdrop of Nepal's raging Maoist rebellion made the royal family massacre a politically sensitive and disastrous development. The government, already weakened by a Maoist guerrilla group that controlled more than half of the country

${ }^{178}$ Karl Taro Greenfeld, “The Death of Vishnu," Time, 2001, http://content.time.com/time/magazine/article/0,9171,128973,00.html.

${ }^{179}$ Ibid. 
by 2001, found itself in a precarious position given that King Birendra enjoyed immense support from the populace. ${ }^{180}$ King Gyanendra was not very popular amongst the Nepalis; his son Paras, who was soon to be Crown Prince, much less so. ${ }^{181}$ Paras had long been known for disregarding public law and also killing a famous musician in a hit-and-run case. ${ }^{182}$ As for Gyanendra, he was long considered to be disgruntled with Birendra over the cessation of power to the civil political parties. ${ }^{183}$ Gyanendra and his son did not enjoy the goodwill that was extended to Birendra; this led to the speculation that the monarchy faced a tumultuous future in Nepal.

The shift of the largely ceremonial role of the King of Nepal from Birendra to Gyanendra is a critical juncture as it highlighted the shift in the role of the Nepali Army. Since the democratization of Nepal in 2001, the monarch had ceded power to a democratically elected parliament. Yet, the Nepali Army was still under the control of the King of Nepal. ${ }^{184}$ The situation was more complicated as a civil war launched by the Maoists was raging during the massacre of the royal family. The Communist Party of Nepal (Maoist), unhappy with the Nepali Congress led government, announced a "People's War" in 1996; it sought to establish a "people's republic" by abolishing the monarchy. ${ }^{185}$ It grew

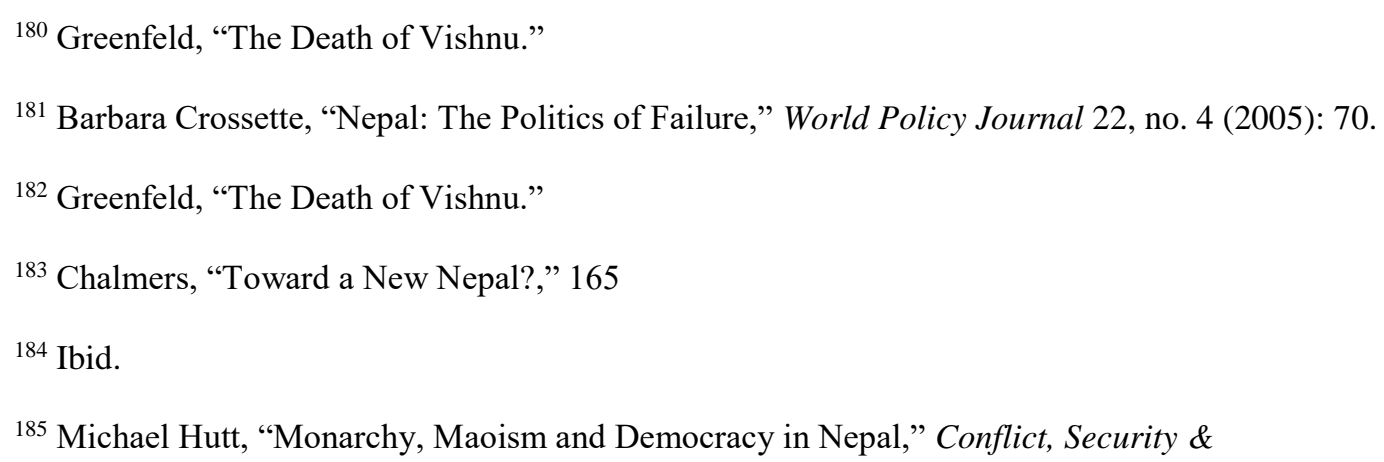


as a move to address vast inequities in Nepal's socioeconomic landscape. King Birendra had long refused to deploy the Royal Nepal Army, arguing that he could not mobilize the Army against his own subjects. ${ }^{186}$ The end of King Birendra's reign had serious implications for the Nepali Civil War; King Gyanendra had the predisposition to use the armed forces against the Maoists, which he did after being crowned the King of Nepal in 2001. ${ }^{187}$ Thus, the Nepali royal family massacre had implications that had the ability to impact the stability of the country. As such, both of its neighbors, India and China, had paid close attention to the situation. The monarchy was seen as the one institution in Nepal that had time and again turned to China to balance India's preponderance in the country. ${ }^{188}$ On the contrary, the political parties, particularly the Nepali Congress, had long enjoyed the support of India, which had time and again expressed dissatisfaction with the Nepali monarch. ${ }^{189}$ Thus, the change in the monarch in Nepal would have implications for the whole buffer system.

The crisis for this critical juncture was the abrupt ending of King Birendra's reign and the plunging of Nepal into political turmoil. It was a crisis given the prospects of shifts in internal security dynamics and foreign relations of Nepal. The ideational change that accompanied the royal family massacre was the political disposition of the new monarch. The willingness of Gyanendra to utilize the Royal Nepali Army against the Maoists and

\footnotetext{
${ }^{186}$ Hutt, "Monarchy, Maoism and Democracy in Nepal," 96.

187 John Mage, “The Nepali Revolution and International Relations," Economic and Political Weekly 42, no. 20 (2007): 1835.

${ }^{188}$ Rama Kant, “Nepal's Foreign Policy and China,” 206.

${ }^{189}$ Sinderpal Singh, India in South Asia: Domestic Identity Politics and Foreign Policy from Nehru to the BJP (New York, NY: Routledge, 2015), p.41.
} 
his dissatisfaction with his brother's acquiescent to democratic reforms signaled a change in the ideational outlook of the monarchy, which would have ramifications for the buffer system given that the monarchy had a history of using the "China Card" and the political parties enjoyed support from India. Thus, the policy changes after the royal family massacre were tied to domestic politics in Nepal, namely changes towards the Maoists. Gyanendra had long favored the use of a military solution to the civil war, which would be a stark departure from Birendra's refusal to mobilize the Royal Nepali Army.

\section{Suspension of Parliamentary Democracy in Nepal}

Following the royal family massacre of 2001, King Gyanendra came to power. The Maoist rebellion that was raging across Nepal's hinterlands had severe implications for law and order of the country, which was exacerbated by the crisis in the royal palace. Unlike King Birendra, Gyanendra disposition was to quickly mobilize the Royal Nepali Army against the Maoists. ${ }^{190}$ King Gyanendra, wary of the performance of the democratically elected government against the Maoists, dissolved parliament in 2002. ${ }^{191}$ The reasoning behind the dissolution of parliament was the failure of the civilian government to negotiate with the Maoists. ${ }^{192}$ A new Head of Government was instated, but constitutional democracy had been severely weakened due to the concentration of power in the monarchy.

\footnotetext{
190 Chalmers, “Toward a New Nepal?” 165

${ }^{191}$ Sumit Ganguly and Brian Shoup, "Nepal” Between Dictatorship and Anarchy," Journal of Democracy, 16(4): 2005, 137.

${ }^{192}$ Chitra Tiwari, "Red Star over the Himalayas," Current History: A Journal of Contemporary World Affairs 104, no. 683 (2005): 296.
} 
Subsequently, in 2005, King Gyanendra assumed absolute power, ending the era of constitutional monarchy established in $1990 .{ }^{193}$ The King not only dissolved elected representatives; he sought to curtail the freedom of the media. According to an interview with Julia Heming of the Columbia Journalism Review's online CJR Daily, Kunda Dixit, one of Nepal's most prominent journalists and the founding editor of the Nepali Times stated that, "for the first two weeks (after the coup), there were actual soldiers in the newsroom with guns, especially in radio stations, TV stations, internet service providers and daily newspapers." 194 Thus, the 2005 coup witnessed the suspension of all forms of civil rights accorded by the 1990 constitution; Nepal effectively became an absolute monarchy. On 1 February 2005, in his proclamation to the nation, King Gyanendra declared:

"Nepal's independence, national unity and sovereignty are best safeguarded by the intimate relationship between the King and people. An institution of monarchy ever devoted to the country and people and a people with an innate love for their land is the glorious history of the kingdom of Nepal, its present and also its future.",195

${ }^{193}$ Sandra Destradi, "India as a democracy promoter? New Delhi's involvement in Nepal's return to democracy," Democratization, 19(2): 2012, 294.

${ }^{194}$ Crossette, "Nepal: The Politics of Failure," 74.

${ }^{195}$ Michael Hutt, “A Nepalese Triangle: Monarchy, Maoists and Political Parties,” Asian Affairs 38, no. 1 (2007): 12. 
India found itself in a difficult predicament. It feared that the Maoist rebellion in Nepal would spill across the border and form ties with its own homegrown Naxalite movements. ${ }^{196}$ On the other hand, India has had historical ties with Nepal's democratic political parties, particularly the Nepali Congress. The coup was met with intense criticism from the Government of India, which had long supported the establishment of democracy in Nepal. ${ }^{197}$ On the contrary, China had explicitly stated that the royal coup was an internal matter of Nepal, and thus, not condemning usurpation of power by the monarch. ${ }^{198}$ In fact, China was one of the first countries to distance itself from the Maoists; Beijing refused to recognize them as "Maoists." 199 Thus, the suspension of parliamentary democracy in Nepal witnessed two very divergent approaches from its neighbors. Given the fact that it had severe implications for Nepal's role as a buffer, this event is an important historical juncture for the buffer system under study. Furthermore, King Gyanendra's pro-China stance has implications for Nepal's role as a buffer, especially since it had long been considered to be under India's security umbrella.

The crisis in this critical juncture is the royal coup of 2005; it led to a dramatic shift in Nepal's domestic political dynamics. The constitutional monarchy was dissolved to give way to an absolute monarchy with King Gyanendra at the helm. The raging Maoist rebellion made the situation volatile as fears were growing that Nepal would become a

${ }^{196}$ Drew Cottle and Angela Keys, "The Maoist Conflict in Nepal: A Himalayan Perdition?," Australian Journal of International Affairs 61, no. 2 (2007): 173.

${ }^{197}$ Destradi, "India as a Democracy Promoter?” 295.

${ }^{198}$ Destradi, "India as a Democracy Promoter? 296; Mage, “The Nepali Revolution,” 1836.

${ }^{199}$ Cottle and Keys, "The Maoist Conflict in Nepal," 173. 
failed state. The ideational change during this critical juncture is the shift from a constitutional monarchy to an absolute monarchy. Similar to the shifts in 2001, the 2005 coup exacerbated the militaristic outlook of the monarchy in solving the civil war. Policy changes at this juncture could include shifts away from democratic institutions. From the perspectives of the buffered states, India and China, changing internal political make-up posed new challenges. Democratic India found itself in a predicament with an antidemocratic monarch who used the China Card previously on one side and the Maoists with grave internal security threats for its own country. Also, the democratic political parties that India had long supported found themselves in a difficult predicament. As for China, growing international concerns regarding King Gyanendra’s growing authoritarianism and the change in Nepal's domestic politics posed new policy challenges, that would necessitate policy changes.

Beginning with the riots in the Tibetan Autonomous Region (TAR) of China in 2008, subsequent years have witnessed intensified efforts by Beijing to bolster ties with Nepal, much to the chagrin of India. The period between 2008 and 2017 includes contentions in Indo-Nepali relations, especially in the form of a full blown economic blockade in 2015 .

\section{Riots in the Tibetan Autonomous Region}

Riots in the Tibetan Autonomous Region (TAR) of the People's Republic of China in 2008 were the worst protests to hit the region since the Tibetan Uprising of 1959. It erupted in March 2008 after protests by supporters of Tibetan Buddhist monks, arrested for celebrating the conferring of the US Congressional Gold Medal to the Dalai Lama, 
escalated into full-fledged riots. ${ }^{200}$ It coincided with the $49^{\text {th }}$ anniversary of the failed Tibetan Uprising in 1959, which eventually led to the departure of the Dalai Lama from Tibet to India. The riots were a public relations disaster for the Chinese government as they were hosting the 2008 Summer Olympics in Beijing. The riots coincided with numerous disruptions during the Olympics torch rallies by pro-Tibetan groups throughout the world, highlighting serious charges of human rights abuses in the Tibetan Autonomous Region. ${ }^{201}$

The situation in the TAR in 2008 was the gravest for Beijing's internal security since the Tiananmen Square protests in 1989. The Government quickly deployed riot police and took control of the provincial capital Lhasa; it included the deployment of tanks and soldiers as well the blocking of all lines of communication with the city. ${ }^{202}$ The riots also assumed an ethnic dimension, as tensions rose between the ethnic Tibetans and the Han Chinese. The riots spread outside of the TAR into other provinces with ethnic Tibetan populations, namely Sichuan, Qinghai, and Gansu. ${ }^{203}$ Many of the protests were led by Buddhist monks, who were placed under strict surveillance after the riots subsided. The Chinese Communist Party (CCP) took the riots seriously, given that the Olympic Games were to be held the same year in Beijing. The internal security situation in the TAR had implications beyond the region; Chinese authorities banned climbers from the northern side

\footnotetext{
200 The CNN Wire Staff, "Timeline of Tibetan Protests in China," CNN, 2012, http://www.cnn.com/2012/01/31/world/asia/tibet-protests-timeline/index.html.

201 The CNN Wire Staff, “Timeline of Tibetan Protests in China,” CNN, 2012.

202 Ibid.

203 Allegra Stratton and Agencies, "Tibet Protesters Disrupt Olympic Flame Ceremony," The Guardian, 2008, https://www.theguardian.com/world/2008/mar/24/tibet.olympicgames2008.
} 
of Mount Everest. ${ }^{204}$ While it was obvious that the administration in Beijing would enforce such a temporary policy in the TAR, the 2008 riots were to change its relations with its much smaller neighbor to the south, Nepal. Following the climbing ban from the northern side of Mount Everest, the government in Kathmandu followed suit. Nepalese authorities dispatched two dozen armed security personnel, enforced a climbing ban above 6,500 meters, and banned laptops and satellite and internet communication from Everest Base Camp. ${ }^{205}$ It is pertinent to decipher Beijing's pressure on Kathmandu for a proper understanding of the inner workings of the buffer system.

Nepal is home to the second largest Tibetan refugee population in the world. Numbering over 20,000 individuals, the Tibetan refugees in Nepal have long garnered China's concerns. ${ }^{206}$ Since the establishment of diplomatic ties, China had long used the set of policies called the Five Principles of Peaceful Coexistence towards Nepal; just like its interactions with other developing states, China had maintained preference for noninterference. ${ }^{207}$ Despite its global commitment to a "no strings attached" diplomacy, China had become wary of the substantial Tibetan refugee population in Nepal, who had increasingly become vocal in their protests. Beijing sought to pressure the Government of

${ }^{204}$ Jonathan Watts, "Beijing Locks down Lhasa as Crisis Grows," The Guardian, 2008, https://www.theguardian.com/world/2008/mar/16/tibet.china.

${ }^{205}$ Ayson and Taylor, "Carrying China’s Torch," 6.

206 "Tibetan Riots Spread Outside Region," The New York Times, 2008, http://www.nytimes.com/2008/03/16/world/asia/16iht-tibet.4.11148124.html.

${ }^{207}$ Marleen Heuer, “China Increases Influence over Tibetan Refugees in Nepal,” Deutsche Welle, 2016, http://www.dw.com/en/china-increases-influence-over-tibetan-refugees-in-nepal/a-19511365.;

The Five Principles of Peaceful Coexistence included: mutual non-aggression, non-interference in each other's internal affairs, mutual respect for sovereignty and territorial integrity, equality and benefit, and peaceful coexistence. 
Nepal to curb the political activities of Tibetan refugees. In 2005, the Nepali monarch, King Gyanendra, had effectively shut down two major Tibetan organizations: the office of the Dalai Lama's representative in Nepal and the Refugee Welfare Office. ${ }^{208}$ The shutting down of the Refugee Welfare Office was a severe blow for the Tibetan refugees in Nepal as it was the last organization to help them get identity cards and prevent their forcible repatriation to China. The riots of 2008 further exacerbated these concerns; Chinese officials sought to adopt a hardhanded approach to the tumultuous relationship with ethnic Tibetans, be it within the TAR or neighboring states. Thus, 2008 was the watershed year for Sino-Nepali relations; it is considered a critical juncture in the context of this dissertation as it highlighted a significant shift in foreign policy of China towards Nepal.

Beijing had long maintained an arm's distance in dealing with Kathmandu. The aftermath of the 2008 riots in TAR witnessed a more active foreign policy approach. For the first time in bilateral relations between China and Nepal, the Embassy of China in Nepal arranged USD 10 million to be granted to the Nepali Police for purchase of Chinese riot shields and batons. ${ }^{209}$ This move is evidently tied to periodic protests by Tibetan groups in front of the Chinese Embassy in Kathmandu. Additionally, coordination between the security apparatus in China and Nepal became closer; the evidence of this is the number of Tibetans fleeing from TAR into Nepal. Between 1991-2008, the number of Tibetan refugees fleeing into Nepal averaged 2,200 individuals per year; the number had dropped

${ }^{208}$ Marleen Heuer, "China Increases Influence over Tibetan Refugees in Nepal,” Deutsche Welle, 2016, http://www.dw.com/en/china-increases-influence-over-tibetan-refugees-in-nepal/a-19511365.

${ }^{209}$ Reeves, “China’s Self-Defeating Tactics in Nepal,” 527. 
to 171 individuals per year between $2008-2013 .^{210}$ Thus, the year 2008 represents a major critical juncture in the buffer system, as China increasingly projected its interests in Nepal. Operationalizing the critical juncture variable in this case, it is evident that there was an ideational change, particularly regarding China's conception of Nepal in its foreign policy. The crisis was the riots in China, which set off a scurry of concerns for China and emanated into increased interests in Nepal due to its large Tibetan refugee population. The ideational change was largely connected to China's perception of Nepal as a country of strategic security concern, due to its proximity to the TAR. This ideational change culminated in policy changes, wherein China's pledges to Nepal increased substantially and the curbs on Tibetan refugees became more intense. Nepal gained importance in China's foreign policy objectives, as it was integral to the TAR's stability due to its geographic contiguity with the country.

Thus, the year 2008 was a critical juncture in the INCBS as the riots in the Tibetan Autonomous Region sparked policy changes. Such changes in China's foreign policy towards Nepal has implications for the INCBS as China's increasing interests in Nepal are considered a security challenge to India's preponderance in the country. As the traditional power to maintain almost absolute influence in Nepal, the rise of China's interests in the country was definitely a critical juncture for the buffer system as a whole as ideational changes occur in Nepal and India as well. India's ideational changes were tied to its increasing concerns over China's interests in Nepal. As for Nepal, the shift signifies its

210 "Nepal Shuts Down Tibetan Offices," BBC News, 2005, http://news.bbc.co.uk/2/hi/south_asia/4214933.stm. 
growing importance in Sino-Indian interactions and an alternative to India's preponderance.

\section{End of the Nepali Monarchy}

While the riots in the TAR had severe implications for Chinese policies towards Nepal, the internal politics in the country was far from stable. Since the dissolution of elected parliament in 2005 and the beginning of absolute monarchy, King Gyanedra had managed to isolate himself inside and outside Nepal. India was critical of the suspension of democratic rule in Nepal; other international actors such as the US and the EU criticized his move as well and postponed military support that they had offered to fight against the Maoists. ${ }^{211}$ The suspension of democracy by Gyanendra spurred collaboration between the civilian political parties (called the Seven Party Alliance or SPA) ${ }^{212}$ and the warring Maoists. The concentration of power in the monarchy brought together factions that were long separated by ideological cleavages. Briefly after King Gyanendra's coup in 2005, the second-in-command of the Maoists, Baburam Bhattarai declared:

${ }^{211}$ Krishna Hachhethu, "Legitimacy Crisis of Nepali Monarchy," Economic and Political Weekly 42, no. 20 (2007): 1831.

${ }^{212}$ This grouping of civilian political parties was called the Seven Party Alliance (SPA). 


\section{"A brief recapitulation of the incessant struggle between the}

monarchy and democracy since the 1950s in the country should leave no one in any doubt that without the complete abolition of the archaic institution of feudal monarchy and its puppet army, no form of democracy can be secure and institutional in Nepal. ${ }^{213}$

In 2005, both parties met in New Delhi to join forces to end autocratic rule by the monarchy. ${ }^{214}$ The royal coup encouraged both democratic forces and the Maoists to collaborate in ousting the monarchy. Subsequently in April 2006, over three million Nepali people out of a total population of 23 million took part in Jana Andolan II - the second mass uprising for democracy. ${ }^{215}$ The movement permeated beyond political parties and included extensive participation from the public. On 28 April 2006, given enormous domestic and international pressure, King Gyanendra conceded and handed power back to the Parliament that was dissolved by him in $2005 .{ }^{216}$ Lack of military support from external powers such as India, the US, and the UK meant that Gyanendra found himself isolated. He could not maintain military superiority against the Maoists without external support.

${ }^{213}$ Hutt, “A Nepalese Triangle," 12.

214 "Nepal Shuts Down Tibetan Offices," BBC News, 2005, http://news.bbc.co.uk/2/hi/south_asia/4214933.stm.

${ }^{215}$ Barbara Demick, "Tibet's Road Ahead: Tibetans Lose a Haven in Nepal Under Chinese Pressure," Los Angeles Times, 2015, http://www.latimes.com/world/asia/la-fg-tibet-nepal-20150806story.html.

${ }^{216}$ Hutt, “A Nepalese Triangle,” 19. 
Internally, almost all domestic institutions, save the Royal Nepal Army, had turned against the King.

Following the success of Jana Andolan II, the Maoists laid down arms and joined the political mainstream becoming a prominent player in Nepal's post-civil war multiparty democracy. The movement not only led to the end of the Nepali civil war; a strong wave of anti-monarchy fervor was present and political parties acted on its behest. The Parliament, specifically, the lower house called the House of Representatives proceeded to remove the "royal" from all institutions associated with the state. The House issued proclamations that removed the words "His Majesty's" and "Royal" from all organs of the state; "His Majesty's Government of Nepal" became "the Government of Nepal"; and the only state institution still loyal to the King until his last days as absolute monarch, the "Royal Nepalese Army" became "the Nepal Army."217 The democratic parties and the Maoists had reached a deal to curtail the monarchy's political power, which it maintained through the control of the national army.

The interim parliament, which Gyanendra restored, drafted an interim constitution on 24 August $2006 .^{218}$ The interim constitution had one crucial omission: the mention of anything related to the monarchy. It also fixed the first Constituent Assembly election to be held on 10 April 2008. ${ }^{219}$ The Government of Nepal further curtailed the rights of the

\footnotetext{
${ }^{217}$ Hutt, “A Nepalese Triangle,” 19.

218 Ibid., 20.

${ }^{219}$ Bal Gopal Shrestha, "The End of Monarchy in Nepal and Its Delicate Journey Towards a Republic," Contributions to Nepalese Studies 35, no. 1 (2008).
} 
monarch by revoking all of his powers and declaring Nepal a secular state in $2006 .{ }^{220}$ In November of the same year, the SPA and Maoists signed the Comprehensive Peace Agreement (CPA), officially ending the civil war; Maoist weapons were placed under the supervision of the United Nations (UN). ${ }^{221}$ The first Constituent Assembly elections in Nepal resulted in the surprise victory of the Maoists, who won $30 \%$ of the popular vote. ${ }^{222}$ With the Maoists leading in the first Constituent Assembly polls, the question of the monarchy became even more precarious. As expected, the May 28, 2008 convening of the Constituent Assembly of Nepal voted to abolish the monarchy; 560 out of the 575 members of the CA voted for its abolishment. ${ }^{223}$ Thus, the Hindu Kingdom of Nepal became a secular, federal, democratic, and republican state. ${ }^{224}$

The end of the Nepalese monarchy is a major critical juncture in this buffer system as Nepal's domestic political institutions changed significantly with the abolishment of the monarchy. As stated earlier, the monarchy had long been considered a strong actor for maintaining a balance between India and China. With the abolishment of that institution, the dynamics for change within Nepal were obvious as all of the political parties that contested the first Constituent Assembly elections had forged a deal in New Delhi in 2005,

${ }^{220}$ Before the 2006 declaration, Nepal was officially a Hindu Kingdom.

${ }^{221}$ Bal Gopal Shrestha, "The End of Monarchy in Nepal and Its Delicate Journey Towards a Republic," Contributions to Nepalese Studies 35, no. 1 (2008).

222 Ibid.

${ }^{223}$ Whelpton, "Nepal and Bhutan in 2008, 55.

${ }^{224}$ J. S. Singh, "From Hindu Monarchy to Secular Republic: Challenges before Nepal's Constituent Assembly," India Quarterly: A Journal of International Affairs 65, no. 3 (2010): 310. 
under the behest of the Government of India. ${ }^{225}$ While China had backed King Gyanendra citing it as an internal matter of Nepal, it did tacitly support the monarchy by providing limited military support to the Royal Nepali Army. ${ }^{226}$ With the new secular and republican system of governance, both India and China had to reformulate their foreign policy objectives in a radically different domestic political context in Nepal.

\section{The Nepal Earthquakes}

The other major critical juncture in the buffer system was the set of earthquakes that struck Nepal in 2015. On 25 April 2015, an earthquake measuring 7.8 on the Richter Scale struck Nepal; the epicenter was the district of Gorkha in central Nepal. ${ }^{227}$ The country was already one of the most impoverished in the world with weak infrastructure and institutional capacity. The second earthquake occurred on 12 May 2015, further exacerbating concerns over recovery efforts. India and China were swift in deploying disaster relief. Natural disasters have the potential to change the nature of relationships; thus, such occurrences are potential critical junctures. ${ }^{228}$ Both India and China sought to extend their influence through this critical juncture; the earthquakes presented both the buffered states with the opportunity to bolster their influence in the buffer. Despite

${ }^{225}$ Mahendra Lawoti and Anup Kumar Pahari, The Maoist Insurgency in Nepal: Revolution in the Wenty-First Century (New York, NY: Routledge, 2009), 225.

${ }^{226}$ Lawoti and Pahari, The Maoist Insurgency in Nepal, 225.

227 “Nepal Earthquake - Fact Sheet \#1,” USAID, 2015, https://www.usaid.gov/nepalearthquake/fy $15 /$ fs 01 .

${ }^{228}$ Louise K. Comfort, "Disaster: Agent of Diplomacy or Change in International Affairs?" Cambridge Review of International Affairs 14, no.1 (2000): 291. 
humanitarian concerns, the underlying strategic competition tied to disaster diplomacy cannot be ignored in this case. ${ }^{229}$

In the immediate aftermath, China deployed a 62-member International Search and Rescue Team; alongside, Beijing arranged for emergency relief materials, including 20million-yuan worth of tents, blankets, and generators. ${ }^{230}$ India's response was swifter and was the largest of any country that responded to the disaster. Named "Operation Maitri,"231 India mobilized 295 members of its National Disaster Response Force (NDRF); it was also the first responder to the disaster. ${ }^{232}$ As for technical support, India deployed over 13 military aircrafts, including one C-130J, two C-17s, and one IL-76. ${ }^{233}$ As for active personnel, China and India had 370 and 962 members respectively. ${ }^{234}$ A notable absence was that of Chinese military aircraft; while India deployed its air force without much delay, China's relief operations largely relied on cargo planes. This could perhaps be a function of India's sensitivities regarding China's activities in Nepal. Nevertheless, political maneuvering was inherently tied to the relief efforts. Kathmandu rejected teams from

229 "Nepal Earthquake - Fact Sheet \#1," USAID, 2015, https://www.usaid.gov/nepalearthquake/fy15/fs01. "Nepal Earthquake - Fact Sheet \#1," USAID, 2015, https://www.usaid.gov/nepal-earthquake/fy15/fs01.

${ }^{230}$ Ankit Panda, "In Nepal Earthquake's Aftermath, India and China Respond," The Diplomat, 2015, https://thediplomat.com/2015/04/in-earthquakes-aftermath-india-and-china-respond/.

${ }^{231}$ Maitri means "friendship" in Sanskrit, which is the liturgical language in Hinduism - a religion that is followed by a majority of people in both India and Nepal.

${ }^{232}$ Panda, "In Nepal Earthquake's Aftermath, India and China Respond."

${ }^{233}$ Ibid.

234 “India's 'Operation Maitri' in Earthquake-Hit Nepal Ends,” NDTV, 2015, https://www.ndtv.com/india-news/indias-operation-maitri-in-earthquake-hit-nepal-ends-768795. 
Taiwan from aiding in the relief efforts but did accept medical relief. ${ }^{235}$ Both China and India made pledges for Nepal's long-term reconstruction as well. At the International Conference on Nepal's Reconstruction held on June 25, 2015 in Kathmandu, India pledged $\$ 1$ billion and China $\$ 500$ million for the long-term reconstruction efforts in the country. ${ }^{236}$ Thus, India's response was much larger, and its pledges were more prominent than China's.

Despite India's responses being much larger than China's, the benefits from such maneuverings were limited. Directed at the Indian media outlets for crude conduct and overstepping professional conduct, the hashtag "\#GoHomeIndianMedia" trended in Nepal during the relief efforts. ${ }^{237}$ The Indian relief effort was the largest contingent among all the countries that participated in the relief efforts; nevertheless, the public backlash against the Indian media houses undercut much of the goodwill garnered from disaster diplomacy. On the other hand, China quietly reaped the benefits of its quiet diplomacy, despite investing less than India in the rescue and reconstruction efforts in Nepal.

The Nepal earthquakes presented themselves as possible points of departure for the states in the buffer system; it was a prime opportunity for the buffered states to woo the buffer. It is a critical juncture as the natural disaster was the crisis that had the potential to set-off ideational change, particularly regarding strategic gains made by India and China in Nepal. While India approached it in terms of quantity, China strategically used disaster

\footnotetext{
235 “India’s ‘Operation Maitri’ in Earthquake-Hit Nepal Ends,” NDTV.

${ }^{236}$ Ashlyn Anderson and Alyssa Ayres, "Disaster Relief: China and India Come Together," Council on Foreign Relations, 2015, https://www.cfr.org/expert-brief/disaster-relief-china-and-india-cometogether.

237 Tsering Shakya and Ashok Gurung, "Was Nepal a Soft Power Victory for China?," Foreign Policy, 2015, http://foreignpolicy.com/2015/05/01/nepal-china-earthquake-aid-taiwan-power/.
} 
diplomacy to its advantage. As such, prospects for policy change from the Indian side is paramount as investment in disaster diplomacy did not the reap the intended benefits.

\section{Blockade of Nepal}

The earthquakes in Nepal posed serious challenges to state capacity and legitimacy of the democratic forces. These earthquakes exacerbated the internal political issues within the country as public anger grew against government ineffectiveness in the face of a major natural disaster. The political parties in Nepal had failed to promulgate a new Nepali constitution following the declaration of the country as a federal republic in 2008. The Constituent Assembly elected in 2008 failed; thus, a second one was called in 2013, which had largely failed to follow through with the delivery of a new constitution. The earthquakes served as a motivation for completing it, which the parties did.

The Nepali Constitution of 2015 that was passed by the new Constituent Assembly was not accepted by all sectors of Nepali society. The ethnic groups residing in southern Nepal, collectively called the Madhesis, expressed their concerns regarding the new constitution. Decentralization was a major theme of the new federal structure adopted in 2008; the new constitution failed to accord proportional representation of all of Nepal's ethnic groups, most prominently the Madhesis. ${ }^{238}$ The southern Nepalis have largely been accused of "Indian agents" by the mostly high caste Hindu hill elites due to the affinity of Madhesis with Indians across the border. Thus, the new constitution was perceived by Madhesis as a means of maintaining the dominance of Nepal's hill elites; the new

238 "Nepal Earthquake: India and China Pledge Millions in Aid," BBC News, 2015, http://www.bbc.com/news/world-asia-33266422. 
constitution demarcated provinces in such a way that hill groups were still dominant in almost all of them. Additionally, naturalized citizens - including those with mixed Indian and Nepali parentage (which a significant portion of Madhesis share) - were barred from running for a range of public positions, including the presidency and the heads of security agencies. ${ }^{239}$ The adoption of the new constitution prompted Madhesi based political parties to form the United Democratic Madhesi Front (UDMF), which led waves of agitations against the promulgation of the new constitution. Citing domination from the hill elites, the UDMF sought to champion the rights of marginalized Madhesis in southern Nepal.

On September 20, 2015, the second Constituent Assembly in Nepal adopted the new constitution. As soon as it did so, India expressed displeasure; it "noted" the adoption of the new charter. ${ }^{240}$ India urged the political parties in Nepal to make the new constitution as inclusive as possible. Nevertheless, the lack of enthusiasm in New Delhi was perceived as covert Indian interference in Nepal. The UDMF launched agitation in the south, crippling the movement of goods and services across the Indo-Nepali border. Nepal relies almost exclusively on India for trade. As such, the agitation by Madhesi groups led to widespread shortage of gas, diesel, kerosene, and cooking gas in all of Nepal's' hilly and mountainous regions - areas already severely impacted by the earthquakes in April of 2015. ${ }^{241}$ India rejected claims that it was orchestrating an economic blockade on Nepal,

\footnotetext{
${ }^{239}$ Soutik Biswas, "Why Is Indian Media Facing a Backlash in Nepal?,” BBC News, 2015, http://www.bbc.com/news/world-asia-india-32579561.

${ }^{240}$ Ibid.

${ }^{241}$ Bikash Sangraula, "Nepal Accuses India of an Economic Blockade as Border Trade Freezes Up,” Christian Science Monitor, 2015, https://www.csmonitor.com/World/Asia-SouthCentral/2015/0928/Nepal-accuses-India-of-an-economic-blockade-as-border-trade-freezes-up.
} 
instead blaming the Madhesi parties for the stoppage of economic activities. While the Madhesi groups launched agitations throughout southern Nepal, the Indian security personnel prevented cargo trucks from crossing into Nepal. ${ }^{242}$ The standoff prompted a lull in bilateral relations between India and Nepal, touted as being at its worst in decades.

The blockade led to widespread shortage of essential fuels in major cities across Nepal. The economic hardship during this period prompted the Nepali government to reduce its dependence on India. In December 2015, the Government of Nepal announced plans to construct three fuel depots, each with a capacity of 6,000 kiloliters of petrol with the aid of the Chinese government. ${ }^{243}$ The Nepali Government also requested Beijing to expand the Araniko Highway which connects the two countries. ${ }^{244}$ While Nepal was increasingly looking to China for respite, the humanitarian crisis within the county exacerbated. Due to shortages in essential vaccines and medications, the United Nations Children's Fund (UNICEF) projected over three million children under the age of five to be adversely affected. ${ }^{245}$ Risk of hypothermia and malnutrition existed, especially in the immediate aftermath of the devastating earthquakes of April and May. Goodwill for India garnered during the earthquake relief efforts evaporated; a whole new generation of Nepalis were faced with the reality wherein their day to day activities were disrupted due

${ }^{242}$ Sangraula, "Nepal Accuses India of an Economic Blockade.”

243 Prashant Jha, "Nepal's Contested Constitution Deepens Crisis at Home and With India," World Politics Review, 2015, https://www.worldpoliticsreview.com/articles/17126/nepal-s-contested-constitutiondeepens-crisis-at-home-and-with-india.

244 Sangraula, "Nepal Accuses India of an Economic Blockade."

245 “Nepal Plans to Build Three More Fuel Depots," The Himalayan Times, 2015, https://thehimalayantimes.com/business/nepal-plans-to-build-three-more-fuel-depots/. 
to the Indian efforts to dictate its way into Nepal's constitution (albeit using the proxy of the Madhesi groups). Rajan Bhattarai, a member of parliament and a Central Committee member of the UML party in Nepal, stated the following:

"We have a rich, multidimensional relationship with India as a result of our shared geography, culture and history, and we want to continue it. But India must recognise that we are two different sovereign nations. We have a right to choose our own constitution, which was passed by an overwhelming majority. India cannot demand an amendment. We will decide what's best for us. "246

The blockade by India brought to the fore the perpetual question in Nepal - that of overdependence on India. Nepal turned to China to alleviate some of its problems with fuel shortages. Beijing agreed to provide 1.3 million liters of gasoline to Nepal, the first time that such a supply was delivered. ${ }^{247}$ It was only on 8 February 2016, after five months of its initiation, that the UDMF lifted the blockade and officially ended shortages of essential fuels in the country. The blockade cost Nepal $\$ 5$ billion in financial loss, on top of the $\$ 7$ billion damage caused by the earthquake. ${ }^{248}$ While India and Nepal moved forward to mend

246 "Nepal to Request China to Expand Araniko Highway," E-Kantipur, 2015, http://kathmandupost.ekantipur.com/news/2015-11-29/nepal-to-request-china-to-expand-aranikohighway.html.

${ }^{247}$ Rishi Iyengar, "Millions of Children Are At Risk Because of the Nepal Blockade, UNICEF Warns," Time, 2015, http://time.com/4130341/nepal-blockade-vaccine-shortage-children-unicef/.

248 Debashish Roy Chowdhury, "China Scores as Nepal Plays Hardball with India Over Border 'Blockade," South China Morning Post, 2015, http://www.scmp.com/news/china/diplomacydefence/article/1898210/china-scores-nepal-plays-hardball-india-over-border. 
ties, the damage was apparent. In October 2015, Nepali Oil Corporation and PetroChina both state-run companies - signed a memorandum of understanding of future trade, which would break India's 40-year old monopoly on Nepal's oil imports. ${ }^{249}$ Thus, the blockade of Nepal was a significant departure, particularly over the question of fuel transportation. There was an inherent realization in Nepal's political elites of its vulnerability to Indian pressures; further integration with China, albeit more challenging due to topographic and demographic considerations, would prove fruitful for decreasing reliance on Indian preponderance in Nepal.

\section{$\underline{\text { Nepal's Entry into China's Belt and Road Initiative }}$}

The One Belt, One Road (OBOR) Initiative, later renamed the Belt and Road Initiative (BRI), is a massive undertaking of economic integration led by China. ${ }^{250}$ The Government of the People's Republic of China calls it the New Silk Road, although it also includes maritime trade routes. ${ }^{251}$ The Initiative was launched in 2013 by Premier Xi Jinping, with an initial pledge of $\$ 40$ billion. ${ }^{252}$ The BRI sought to connect road and sea routes between China and the countries in Southeast Asia, Central Asia, and Europe, with

\footnotetext{
${ }^{249}$ Shannon Tiezzi, "China Steps In After Indian Fuel Stops Flowing to Nepal," The Diplomat, 2015, https://thediplomat.com/2015/10/china-steps-in-after-indian-fuel-stops-flowing-to-nepal/.

${ }^{250}$ As per Shepard (2017), the name "One Belt, One Road" put too much emphasis on the idea of the presence of "one" trade route, while in reality there are five routes (both land and maritime) that are designed to connect Asia, Europe, and Africa. Thus, the name Belt and Road Initiative (BRI) was officially adopted by the People's Republic of China to prevent misinterpretation.

251 "With Blockade Lifted, India Can Influence Nepal," Stratfor, 2016, https://worldview.stratfor.com/article/blockade-lifted-india-can-influence-nepal.

${ }^{252}$ Ibid.
} 
South Asia being included later. As of June 2017, the PRC has committed \$1.4 trillion to the initiative, which seeks to integrate trade links in Eurasia by the development of infrastructure including roads, rail, airports, ports, pipelines, and communications. ${ }^{253}$ The BRI incorporates two components: the land-based "Silk Road Economic Belt" and the seagoing " $21{ }^{\text {st }}$ Century Maritime Silk Road." ${ }^{254}$ Figure 10 highlights the magnitude of this massive undertaking.

The economic rationale for the BRI largely rests on China's long-term strategic goals. It is currently dependent on its eastern seaboard and the Malacca Strait near Singapore, which is a possible strategic bottleneck. ${ }^{255}$ As depicted in Figure 11, ${ }^{256}$ Titled the "Malacca Dilemma," Beijing has long sought to reduce its reliance in the sea routes passing through Malacca Straits and the BRI is designed to do just that. The China-Pakistan Economic Corridor (CPEC) and the development of Gwadar Port in Pakistan is a means of circumventing the Malacca Straits; China is doing the same in energy-rich Central Asia by integrating land-based trade routes. ${ }^{257}$

253 "Full Text: Action Plan on the Belt and Road Initiative," The State Council, The People's Republic of China, 2015, http://english.gov.cn/archive/publications/2015/03/30/content_281475080249035.htm.

${ }^{254}$ William T. Wilson, "China's Huge 'One Belt, One Road' Initiative Is Sweeping Central Asia," The Heritage Foundation, 2016, http://www.heritage.org/asia/commentary/chinas-huge-one-belt-one-roadinitiative-sweeping-central-asia.

${ }^{255}$ Joshua P. Meltzer, "China's One Belt One Road Initiative: A View from the United States," 2017, https://www.brookings.edu/research/chinas-one-belt-one-road-initiative-a-view-from-the-unitedstates/.

${ }^{256}$ For Figure 11, refer to page number 128.

257 "The Belt and Road Initiative - A Road Map to the Future," The Hong Kong Trade Development Council, 2017, https://beltandroad.hktdc.com/en/belt-and-road-basics. 
Figure 10: China's Belt and Road Initiative

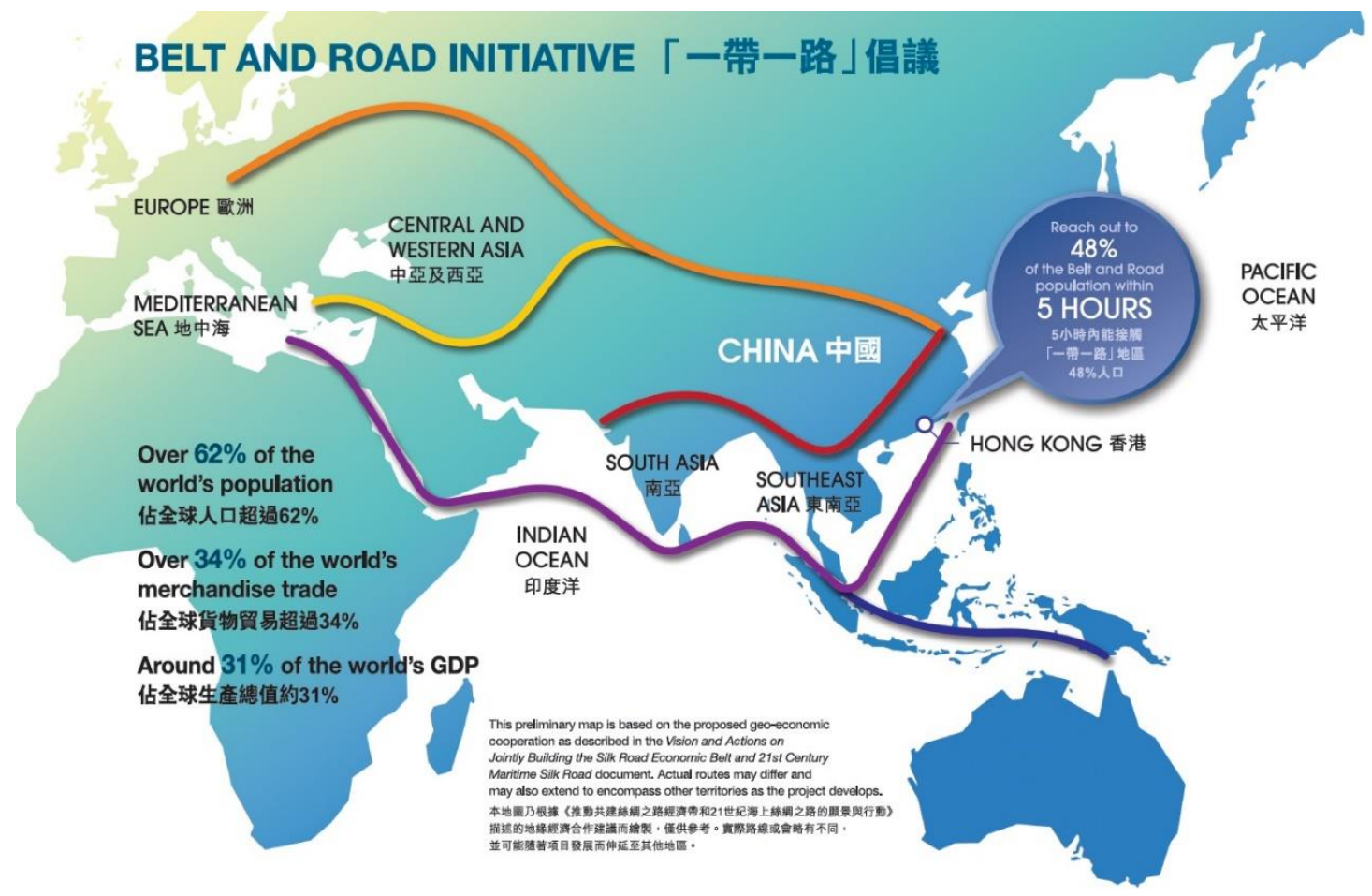

The BRI was institutionalized through the Belt and Road Forum (BRF), which convened for the first time on 14 May 2017. Over fifty countries sent their heads of states or government representatives to the Forum, including Nepal. Just two days before on 12 May, Nepal had signed a memorandum of understanding with China to participate in the BRI. ${ }^{258}$ The Government of India strongly objected to Nepal's joining of the BRI, particularly since India has refused to become a part of the BRI. ${ }^{259}$ India also refused to send official delegates to the first BRF. Thus, Nepal's entry into the BRI was a major

\footnotetext{
258 Anja Manuel, "China Is Quietly Reshaping the World,” The Atlantic, 2017, https://www.theatlantic.com/international/archive/2017/10/china-belt-and-road/542667/.

${ }^{259}$ Vidya Sagar Reddy, "Reinforcing China's Malaccas Dilemma," Center for International Maritime Security, 2016, http://cimsec.org/reinforcing-chinas-malacca-dilemma/28117.
} 
critical juncture as it joined the initiative despite India's security concerns. Since the entry of Nepal into BRI, China has committed to expand high-speed railway line up to Nepal's border and expand it into the country's south, to Lumbini, which is Buddha's birthplace and a major site of the religion's pilgrimage circuit. ${ }^{260}$ The prospects of such an extension of railroad is problematic for India, as Lumbini is less than an hour away from India's border.

\section{Figure 11: The Malacca Straits ${ }^{261}$}

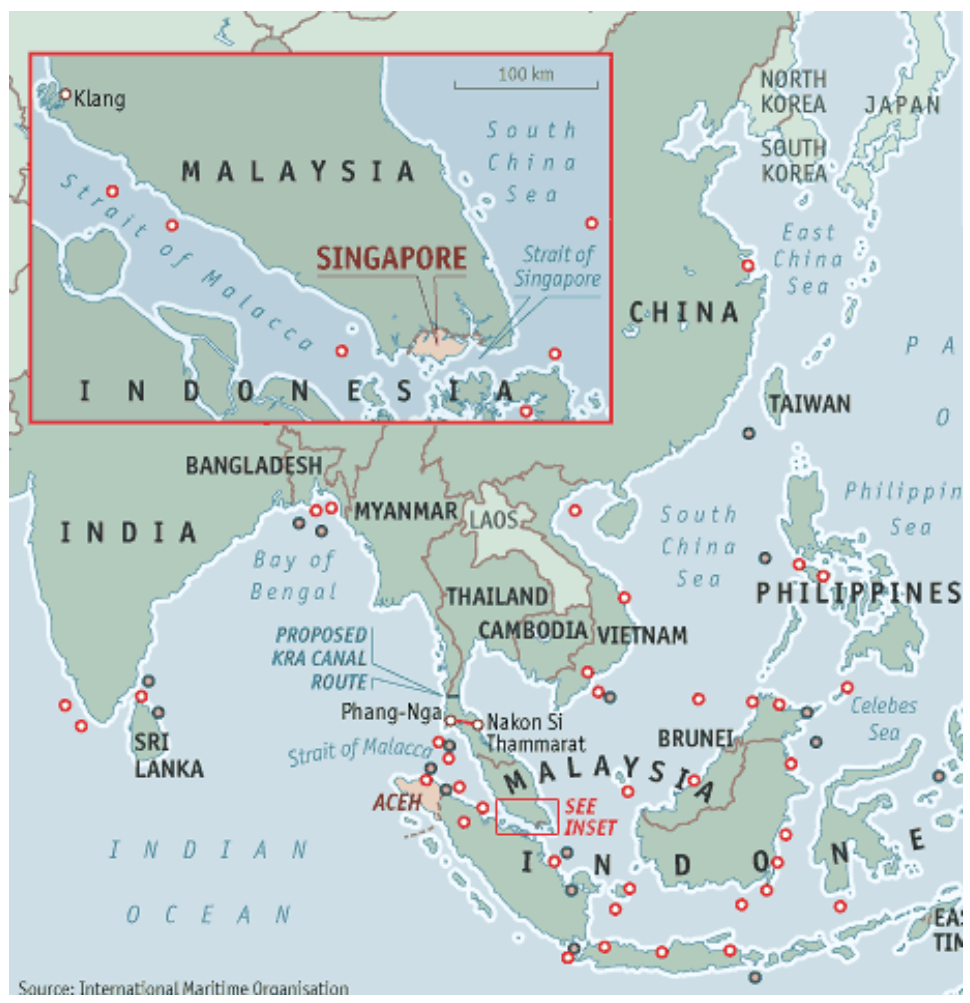

${ }^{260}$ Bishal Chalise, “China’s Belt and Road Reaches Nepal,” East Asia Forum, 2017, http://www.eastasiaforum.org/2017/06/17/chinas-belt-and-road-reaches-nepal/.

${ }^{261}$ Rupak Sapkota, “Nepal's Role in China’s Belt and Road Initiative Highlights Balancing Act between Beijing and Delhi," South China Morning Post, n.d.,

http://www.scmp.com/news/china/diplomacy-defence/article/2110474/nepals-role-chinas-belt-and-roadinitiative-highlights. 
The BRI is a major strategic undertaking of China with extensive importance for the buffer system under study. China is the initiator of the BRI; India has refused to become a part of it citing security concerns; ${ }^{262} \mathrm{Nepal}$, on the other hand, joined the Initiative after its experience with the blockade in 2015. Thus, the entry of Nepal into BRI is a major critical juncture that showcases its maneuvering in the sub-systemic discord between India and China. Table 2 summarizes the critical junctures detailed in this chapter. It provides the crisis that set off ideational changes which in turn led to policy changes in the specific years chosen as critical junctures.

Table 2: Mapping of the Critical Junctures in the India-Nepal-China Buffer System (1990-2017)

\begin{tabular}{|c|c|c|c|}
\hline Critical Juncture & Crisis & Ideational change & Policy change \\
\hline $\begin{array}{l}\text { Democratization } \\
\text { of Nepal }\end{array}$ & $\begin{array}{l}\text { Pressure against the } \\
\text { panchayat system } \\
\text { (absolute } \\
\text { monarchy); political } \\
\text { parties launch street } \\
\text { protests }\end{array}$ & $\begin{array}{l}\text { Transformation of Nepal } \\
\text { from an absolute } \\
\text { monarchy to a } \\
\text { constitutional monarchy }\end{array}$ & $\begin{array}{l}\text { The monarchy had } \\
\text { long used China as a } \\
\text { "balance" against; } \\
\text { change of domestic } \\
\text { make-up of Nepal } \\
\text { meant that } \\
\text { democratic forces } \\
\text { supported by India } \\
\text { had appeared } \\
\text { triumphant. China } \\
\text { had to reassess its } \\
\text { foreign policy } \\
\text { towards Nepal }\end{array}$ \\
\hline $\begin{array}{l}\text { Nepalese Royal } \\
\text { Family Massacre }\end{array}$ & $\begin{array}{l}\text { Death of the royal } \\
\text { family; beginning of } \\
\text { Gyanendra's reign; } \\
\text { civil unrest and } \\
\text { raging civil war }\end{array}$ & $\begin{array}{l}\text { The military is seen as the } \\
\text { solution to the civil war; } \\
\text { departure from Birendra's } \\
\text { non-military confrontation } \\
\text { with the Maoists }\end{array}$ & $\begin{array}{l}\text { Shift of security } \\
\text { policy from } \\
\text { Gyanendra to } \\
\text { Birendra: Usage of } \\
\text { military means to } \\
\text { solve the civil war }\end{array}$ \\
\hline
\end{tabular}

${ }^{262}$ As part of CPEC, China is investing in roads that run through the disputed territory of Pakistani administered Kashmir. 


\begin{tabular}{|c|c|c|c|}
\hline $\begin{array}{l}\text { Suspension of } \\
\text { Parliamentary } \\
\text { democracy in } \\
\text { Nepal }\end{array}$ & $\begin{array}{l}\text { Royal coup - } \\
\text { establishment of } \\
\text { absolute monarchy }\end{array}$ & $\begin{array}{l}\text { From democratic } \\
\text { governance to } \\
\text { authoritarianism; } \\
\text { prospects for growing } \\
\text { armed violence }\end{array}$ & $\begin{array}{l}\text { India: authoritarian } \\
\text { govt vs. Maoists vs. } \\
\text { political parties } \\
\text { China: non- } \\
\text { interference? }\end{array}$ \\
\hline $\begin{array}{l}\text { Riots in the } \\
\text { Tibetan } \\
\text { Autonomous } \\
\text { Region (2008) }\end{array}$ & $\begin{array}{l}\text { Eruption of riots in } \\
\text { the TAR }\end{array}$ & $\begin{array}{l}\text { Beijing's extensive } \\
\text { presence in the TAR; } \\
\text { Nepal emerges as a } \\
\text { country that is of } \\
\text { significant importance to } \\
\text { stabilize the TAR }\end{array}$ & $\begin{array}{l}\text { Increasing Chinese } \\
\text { interests mean } \\
\text { increased aid that } \\
\text { seeks to constrain the } \\
\text { Tibetan refugee } \\
\text { population in Nepal }\end{array}$ \\
\hline $\begin{array}{l}\text { End of the } \\
\text { Nepalese } \\
\text { monarchy (2008) }\end{array}$ & $\begin{array}{l}\text { Massive protests } \\
\text { against authoritarian } \\
\text { rule of King } \\
\text { Gyanendra }\end{array}$ & $\begin{array}{l}\text { From monarchy to a } \\
\text { republic; from unitary } \\
\text { government to a federal } \\
\text { one }\end{array}$ & $\begin{array}{l}\text { Toppling of a } \\
\text { traditional balancer } \\
\text { in Nepal's relations } \\
\text { with India and } \\
\text { China; prospects for } \\
\text { political shifts; India } \\
\text { major player in } \\
\text { brokering peace; } \\
\text { reformulation of } \\
\text { foreign policy } \\
\text { needed for China } \\
\text { who had supported } \\
\text { the King }\end{array}$ \\
\hline $\begin{array}{l}\text { The Nepal } \\
\text { Earthquakes } \\
(2015)\end{array}$ & $\begin{array}{l}\text { Two major } \\
\text { earthquakes in } \\
\text { Nepal }\end{array}$ & $\begin{array}{l}\text { Potential for strategic gain } \\
\text { through disaster } \\
\text { diplomacy }\end{array}$ & $\begin{array}{l}\text { Despite more } \\
\text { investment, India } \\
\text { reaped less than } \\
\text { China, particularly in } \\
\text { terms of garnering } \\
\text { goodwill in Nepal; } \\
\text { prospects for policy } \\
\text { change - how to } \\
\text { garner benefits from } \\
\text { investments (like } \\
\text { China did) }\end{array}$ \\
\hline $\begin{array}{l}\text { Blockade of Nepal } \\
\text { (2015) }\end{array}$ & $\begin{array}{l}\text { Lull in Indo-Nepali } \\
\text { relations; } \\
\text { humanitarian crisis } \\
\text { in Nepal }\end{array}$ & $\begin{array}{l}\text { Realization of over } \\
\text { reliance on India - } \\
\text { vulnerability to Indian } \\
\text { pressures }\end{array}$ & $\begin{array}{l}\text { Crisis mitigation } \\
\text { with India - but also, } \\
\text { integrating with } \\
\text { Chinese endeavors in } \\
\text { the political economy } \\
\text { of Eurasia; first } \\
\text { instance of supply of } \\
\text { fuel from China. }\end{array}$ \\
\hline $\begin{array}{l}\text { Nepal joining the } \\
\text { BRI (2017) }\end{array}$ & $\begin{array}{l}\text { No crisis per se; } \\
\text { Nepal's attempt to } \\
\text { reduce its reliance } \\
\text { on India }\end{array}$ & $\begin{array}{l}\text { Joining of the BRI - focus } \\
\text { on economic benefits of } \\
\text { joining the initiative }\end{array}$ & $\begin{array}{l}\text { Affirmation of } \\
\text { China-Nepal } \\
\text { relations; security } \\
\text { concerns for India - } \\
\text { ramifications of the } \\
\text { blockade. }\end{array}$ \\
\hline
\end{tabular}




\section{CHAPTER V: DATA ANALYSIS AND ORGANIZATION}

Chapter V deals with the analysis and organization of the collected qualitative and quantitative data for the convergent parallel design. It includes the conduct of qualitative and quantitative data analyses, their comparison, and the convergence of both approaches to decipher whether the political rhetoric distilled from the qualitative data is in convergence with the quantitative data. The convergence of both analyses will be interpreted in Chapter VI.

The first section of the chapter focuses on the quantitative data analysis of the mixed design. The quantitative data that is gathered for all the critical junctures are organized to ascertain whether such junctures have led to the increase or decrease in the four indicators: trade (export/import figures in USD), Foreign Direct Investment (FDI), and foreign aid. Quantitative analysis was then conducted on the collected data. This includes the Kruskal-Wallis Test (KWT) of the data collected for trade, foreign direct investment (FDI), foreign aid, and cultural exchanges and scholarships. The KWT is used for the study as the three indicators are separately used as the dependent variable (DV), while there is one independent variable (IV) that is expressed in the form of two or more categorical factors. The data sets are divided into three disparate groups based on the pre-, during, and post- critical juncture periods for a more nuanced analysis. Each indicator used in the quantitative analysis has separate forms of identifying factors, which are discussed in their corresponding sections in this chapter. Additionally, nonparametric correlations were run using the same data. 
The second section of the chapter deals with qualitative data analysis, which focuses on the content analysis of sampling that consists of joint intergovernmental agreements (between India-Nepal and China-Nepal), foreign policy statements (from India and China concerning Nepal or from Nepal concerning its neighbors). Both negative and positive assertions are deciphered pre-, during, and post-critical juncture periods to assess rhetorical changes at these points in time. As part of content analysis, the qualitative data will be organized on the basis of whether the buffer's role changed or remained the same before and after the historical critical junctures, while contextualizing it within intense or dampened Sino-Indian competition. Thus, a comparative framework is used for this section wherein pre- and post- critical juncture years are compared to analyze rhetorical changes due to critical junctures and decipher if rhetoric is reinforced by actual material flows from the buffered states (China and India) to the buffer state (Nepal).

In the third section of the chapter, the analyzed data are organized to facilitate the process of convergence/divergence and collective interpretation of the results. While quantitative and qualitative analyses are conducted separately, the convergent parallel design requires a collective interpretation of all analyses carried out, which is covered in Chapter VI. For this section, the analyzed data is organized for the process of Convergence, which smoothens the process of joint interpretation. Thus, data organization for the qualitative and quantitative analyses are done separately but concurrently compared during the process of Convergence. The analyzed data from the qualitative analysis is organized and analyzed on the basis of whether there has been a change or not in the perception of the buffer state at historical critical junctures. 
Overall, the two analyses rest on the increase or decrease in sub-systemic rivalry. From the discussion on critical junctures, such historical years are points of policy change. The independent variable of the study is sub-systemic rivalry between middle or great powers and dependent variable is the buffer state's political relevance beyond just a geographical discontinuity. For these analyses, the independent variable i.e. sub-systemic rivalry is assumed to change significantly in the critical juncture period. As such, to assess this change, the independent variable is split into three categorical factors: pre-, during, and post- critical junctures for the quantitative data analysis. The during critical juncture period is crucial in assessing significant policy shifts as this year signals the disjuncture.

\section{Quantitative Data Analysis}

The three indicators, namely trade, FDI, and foreign aid are used for the quantitative analysis. Data for a year before the critical juncture (labeled as pre-critical juncture), during the critical juncture (labeled the same), and a year after the critical juncture (labeled as post-critical juncture) are collected for each indicator. Details on the sources of data and coding for the indicators are discussed below. As for the development variable, the buffer state's political relevance for the quantitative analysis is operationalized as significant changes in trade, foreign direct investment (FDI) and foreign aid. In essence, the analyses are carried out to assess whether there are significant changes in the political relevance of the buffer state (operationalized as trade, FDI, and foreign aid) when sub-systemic rivalries change (captured by the changes in time period based on the idea the critical junctures foster policy shifts). For example, sub-systemic rivalries are considered intense when there are significant changes in foreign aid during critical juncture period i.e. the critical 
junctures, given their designation as important markers of policy shifts, should showcase upticks in foreign aid from India and China as they are points of contention. Such precarious points of contention should showcase intense competition between India and China in their foreign aid to Nepal. In essence, the quantitative data analysis includes the material engagement aspect of the buffer system interactions.

\section{Trade}

Trade, defined as the totality of goods and services exported and imported, is the dependent variable used to assess whether critical junctures impact economic exchanges in the buffer system. This is particularly true for Indo-Nepali relations as India has used economic blockade as a tool for arm-twisting Nepal. In 1990, Rajiv Gandhi's government instituted an economic blockade protesting Nepal's purchase of anti-aircraft missiles from China; ${ }^{263}$ again in 2015, the Modi government instituted an unofficial blockade as a sign of discontent with Nepal's newly promulgated constitution. ${ }^{264}$ Thus, trade relations are delicate, particularly for buffer states that are geopolitically disposed to heavily depend on the buffered states for economic relations. As such, trade is included as a quintessential part of the buffer system dynamics due to its strategic value and the heavy implications for the buffer state's economy, as showcased by Nepal's experience with the blockades in 1990 and 2015.

263 "Nepal Says Committed to Major Projects under China's Belt and Road Initiative," The Hindustan Times, 2017, http://www.hindustantimes.com/world-news/nepal-says-committed-to-majorprojects-under-china-s-belt-and-road-initiative/story-JKn508Fvg2xRdjKICdhSdP.html. 960-61.

${ }^{264}$ Sangraula, "Nepal Accuses India of an Economic Blockade." 
Trade data was collected from the Observatory of Economic Complexity (OEC) (https://atlas.media.mit.edu/en/). To decipher whether there are changes in trade patterns before (pre-), during, and after (post-) the critical juncture years, The Kruskal-Wallis Test (KWT) was carried out. The KWT is the nonparametric counterpart of the Analysis of Variance (ANOVA), which allows for comparison of more than two populations. As the quantitative analysis of this dissertation has three DVs (trade, foreign direct investment, and loan) as well as one IV (sub-systemic rivalry between India and China), the KWT is the most suitable statistical test given that the data set is not large enough for a parametric test such as ANOVA. The goal is to decipher if there are significant differences in patterns of trade before (pre), during, and after (post) critical junctures i.e. whether trade changed during and after the critical juncture points when compared to the pre-juncture periods. SPSS 22 was used for the analysis. For further clarity, the dependent variable in this case is trade; it is assumed that there will be noticeable patterns of change in trade across the three timeframes of the critical juncture points. The independent variable is intensity of sub-systemic rivalry between India and China. For the sake of further clarity, the independent variable is coded into three categorical factors:

1. Time: It is expressed as "juncture point." The IV is coded to represent the three time frames (pre-, during, post-), which are represented as numbers 1, 2, and 3 respectively;

2. Country: It is expressed as "China Imports", "China Exports", "India Imports", and "India Exports." The designations depend on whether they were imports into Nepal or exports from Nepal to India and China. For example, Nepal's exports to China is 
designated "China Exports"; similarly, Nepal's imports from India is designated "India imports."

3. Export or Import: It is expressed as "Totalimports" and "Totalexports." This includes the total trade figured between Nepal and its buffered states, India and China.

The IV is expressed in three categorical factors to analyze the links between time (pre, during and post critical junctures), or trade partner country (India or China), and export or import on the DV (trade). To put it simply, this test seeks to quantitatively analyze whether there are significant patterns of change for trade at critical junctures; whether there are significant differences in trade patterns between Nepal-China and Nepal-India; and whether there are significant variations in export or import at the critical junctures. As such, critical junctures should showcase increase in sub-systemic rivalry i.e. trade needs to change during such periods.

The Kruskal-Wallis Test was run on SPSS 22 with the data collected for trade. First, the KWT was run for total trade data represented by "Totalimports" and "Totalexports." Second, another KWT was run collectively for "China Imports", "China Exports", "India Imports", and "India Exports" along with the figures for foreign direct investment and foreign aid. The results of the first KWT showcase that there is no statistical significance. The significance for "Totalimports" and "Totalexports" across time i.e. juncture points are .975 and .650 respectively, which are way above the statistical significance threshold of .05. As such, the KWT for total trade yields statistical insignificance. 
The KWT for "China Imports", "China Exports", "India Imports", and "India Exports" also yield no statistical significance. Respectively, .779, .522, .997, and .650 are the significance levels for trade across time, which are statistically insignificant. ${ }^{265}$

Referring to the Descriptive Statistics for Trade in Appendix 3, India's mean export levels are as follows: 530.0678 (Pre), 773.2170 (During), and 790.0378 (Post). As for China, they are 168.5210 (Pre), 183.0311 (During) and 90.6511 (Post). It showcases slight changes for India, as trade seems to show an uptick during critical junctures and increase very slight after it. As for China's mean data, there isn't any significant changes. Figures 12-15 showcase the trends in mean trade figures between Nepal-China and Nepal-India.

Figure 12: Trade between India and Nepal

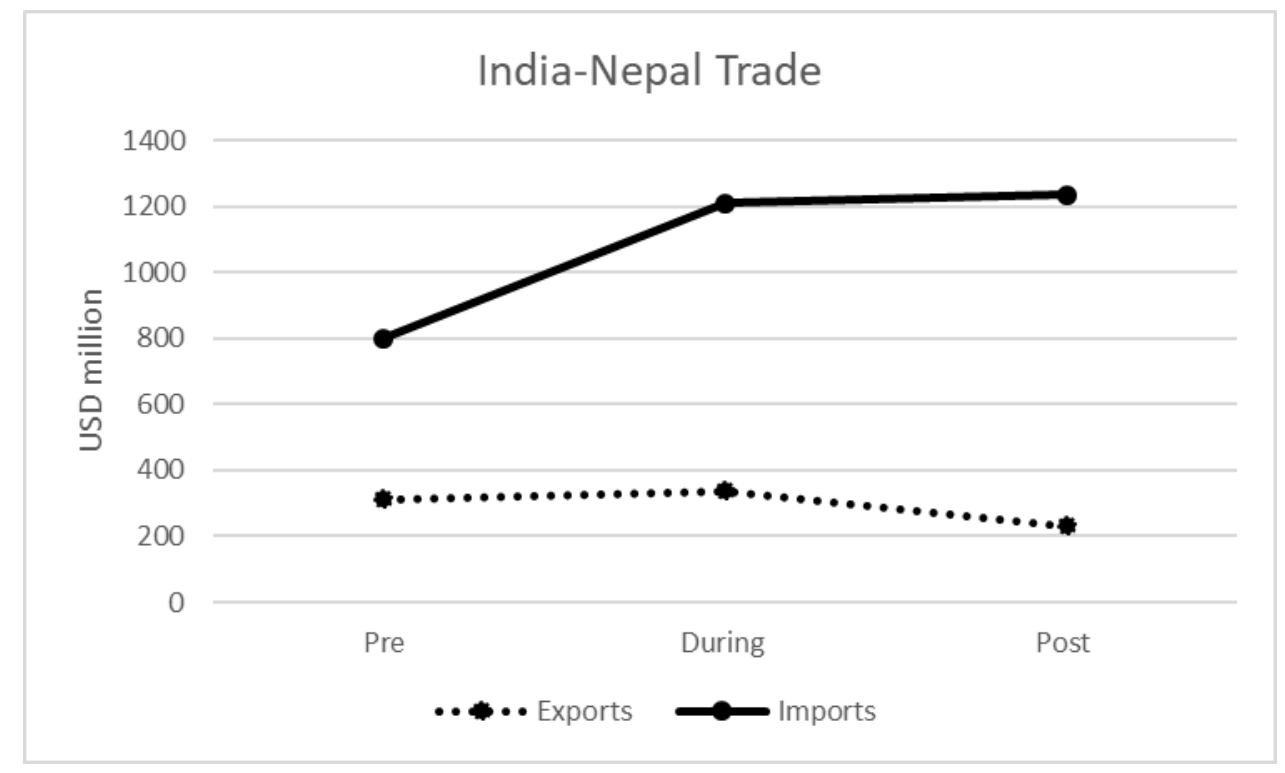

${ }^{265}$ Refer to Appendix 2: Results for Kruskal-Wallis Test for all Variables for detailed results. 
As showcased in Figure 12, the mean trade figures between India and Nepal is heavily skewed towards Nepali imports from India. While statistically insignificant overall in terms of changes across the pre, during and post periods, the mean difference between pre and during critical juncture periods for imports from Nepal is approximately $45.8 \%$, which is a notable increase and needs to be noted. As such, sub-systemic rivalry can be deciphered to have increased given that mean figures of trade took a significant uptick during the critical juncture; the important exception to point out is that this is limited to imports from India into Nepal, which may not hold much political relevance given that Nepal relies heavily on India for trade, showcased in Figure 14.

Figure 13: Trade between China and Nepal

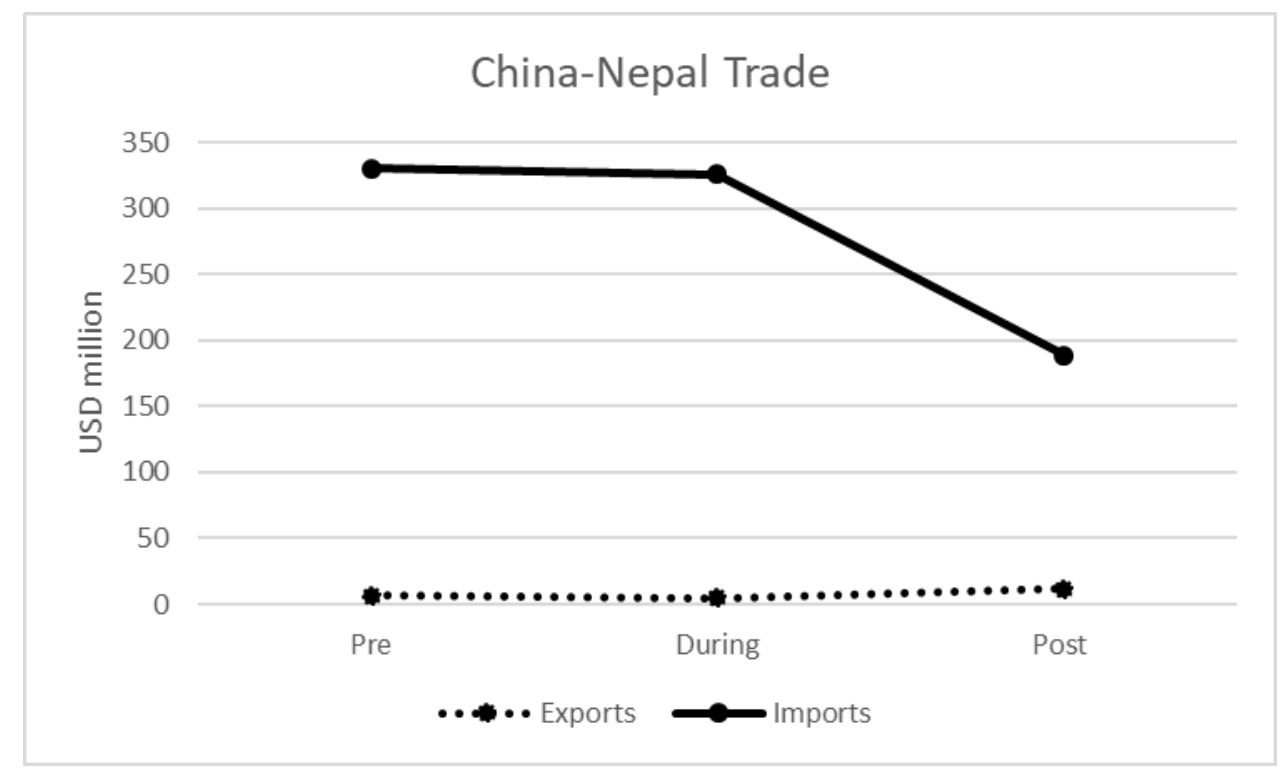


The descriptive statistics for trade showcase that imports from China fell by approximately 42 percent, which is a pretty significant drop in imports. As for pre and during critical juncture periods, import figures remained stable overall. As for exports, the overall trend is heavily skewed by Nepali imports from China.

Figures 13 and 14 display India and China's standing with regard to their trade with Nepal. As discussed, Nepal's import of Indian goods rises at critical juncture points while it drops for the case of China. For export figures, Nepali exports to India pick up slightly in critical junctures but decrease by 31 percent approximately in the post-critical juncture period. As for Nepali exports to China, the figures are much lower and as such, slight changes may lead to significant percentage changes. Nevertheless, Chinese imports into Nepal fell in the post-critical juncture period, while imports from India increased slightly during that same period.

Figure 14: Imports from India and China to Nepal

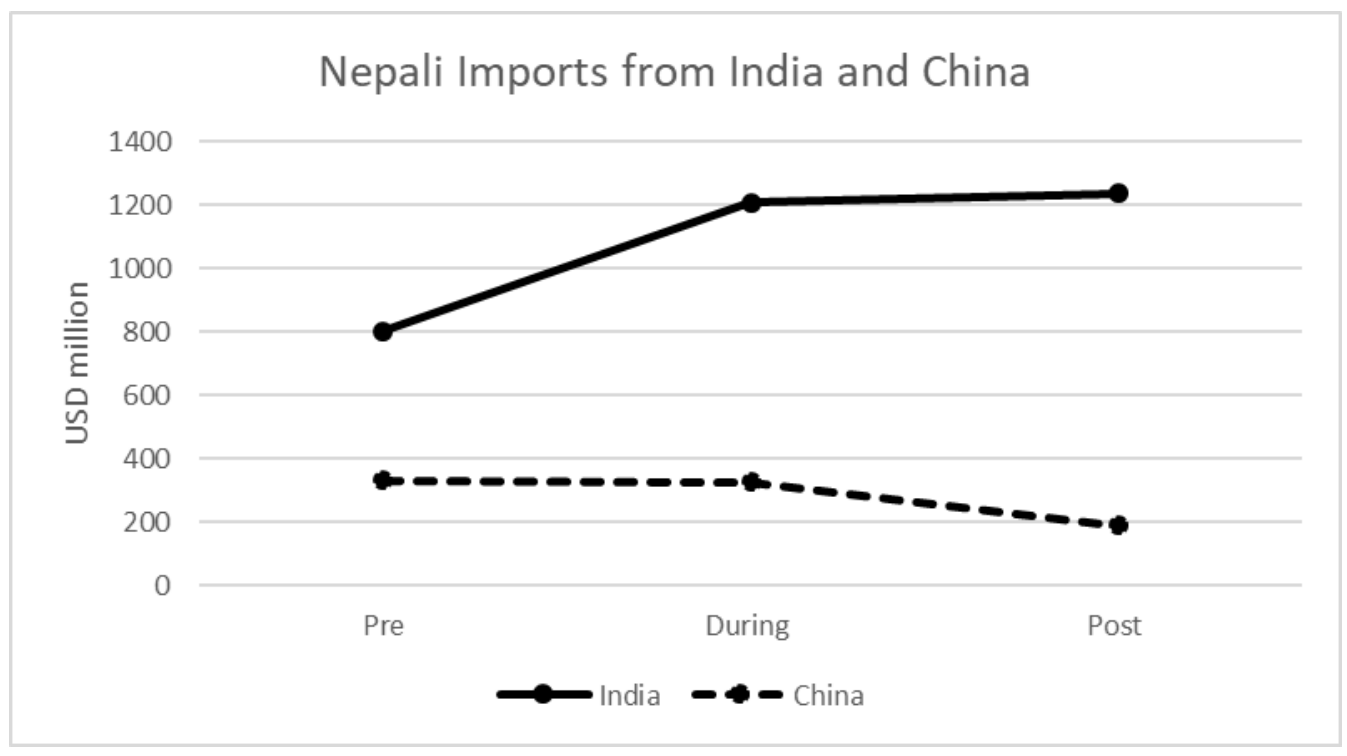


Figure 15: Exports from Nepal to India and China

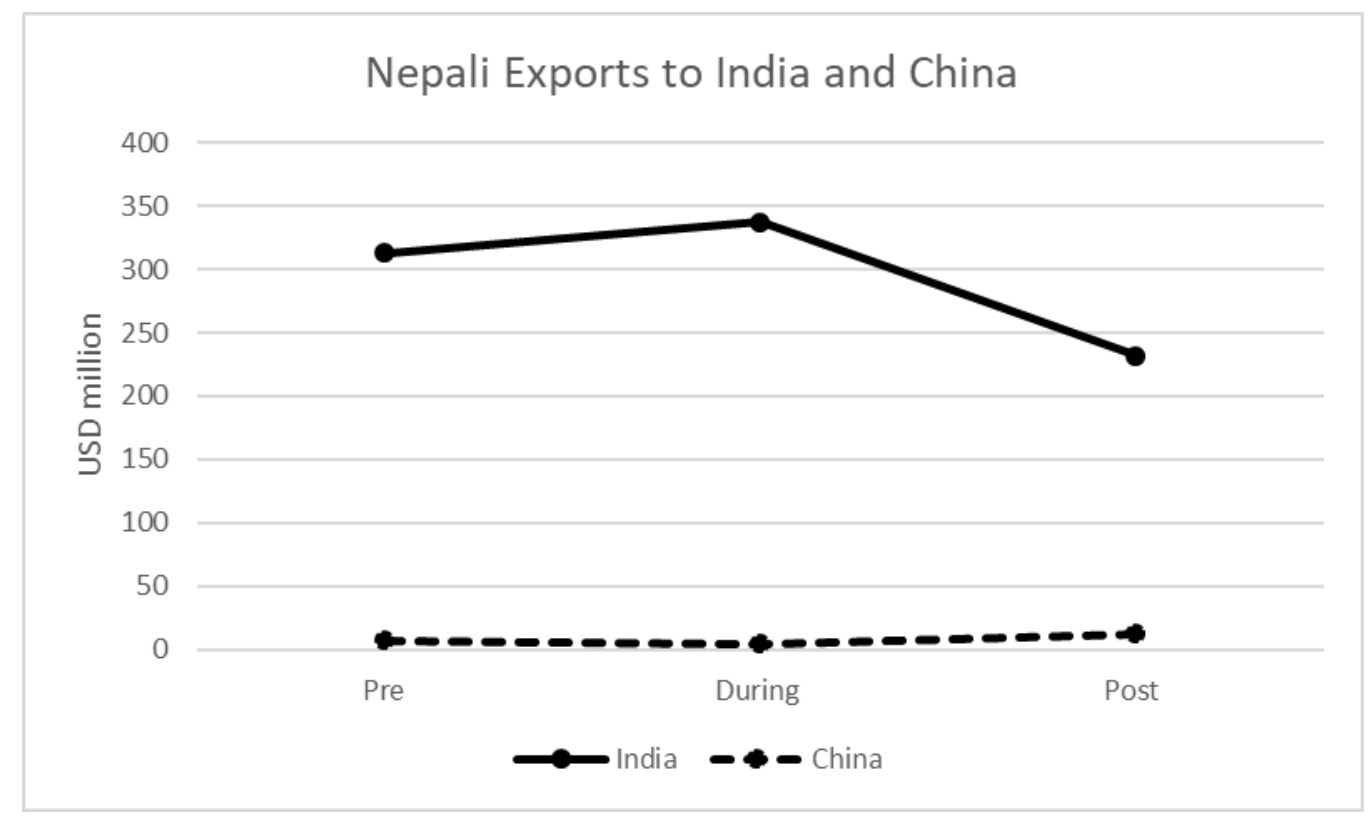

Foreign Direct Investment (FDI)

The United Nations Conference on Trade and Development (UNCTAD) defines FDI as "an investment made to acquire lasting interest in enterprises operating outside of the economy of the investor. Furthermore, in cases of FDI, the investor's purpose is to gain an effective voice in the management of the enterprise." ${ }^{266}$ In essence, FDI indicates the total investment made by business enterprises outside of the host economy. This is important for the dissertation as Indian companies have long maintained a foothold in Nepal. Additionally, FDI showcases whether there is tacit support for them to be used as a tool of influence. For example, Chinese State-Owned Enterprises (SoEs) have long been perceived as strategic players in gaining influence abroad; some scholars point to the fact

\footnotetext{
${ }^{266}$ Sangraula, "Nepal Accuses India of an Economic Blockade as Border Trade Freezes Up."
} 
that Chinese SoEs are primarily supporting China's geopolitical and mercantilist interests. ${ }^{267}$ As such, the FDI data flowing into Nepal is analyzed here to decipher whether there are patterns of changes (i.e. increase/decrease in sub-systemic competition) at critical junctures.

Not all critical junctures could be analyzed for FDI. Complete official records are available only after 2003 for the data on FDI flowing into Nepal from India and China. The data for FDI inflows post-2003 into Nepal from India and China was consolidated from the following sources: United Nations Conference on Trade and Development (UNCTAD); ${ }^{268}$ Nepal-India Chamber of Commerce \& Industry; ${ }^{269}$ Reserve Bank of India (RBI); ${ }^{270}$ ExportImport Bank of India; ${ }^{271}$ and Ministry of Commerce of People's Republic of China, National Bureau of Statistics of People's Republic of China, and State Administration of Foreign Exchange. ${ }^{272}$

267 “Going for the Jugular,” The Economist, 2004, http://www.economist.com/node/2752802.

${ }^{268}$ United Nations Conference on Trade and Development, "Foreign Direct Investment (FDI)," 2017, http://unctad.org/en/Pages/DIAE/Foreign-Direct-Investment-(FDI).aspx.

${ }^{269}$ Ibid.

${ }^{270}$ United Nations Conference on Trade and Development, "Country Fact Sheet: India,” 2017, http://unctad.org/sections/dite_dir/docs/wir2017/wir17_fs_in_en.pdf.

Figures for these data were in Nepali Rupees (NRs.). The figures were converted based on the selling exchange rate for January 19, 2018: USD 1 = NRs. 102.47.

${ }^{271}$ Nepal-India Chamber of Commerce \& Industry, “Top 5 Countries of FDI Commitments in Nepal - Fiscal Year and Country Wise," 2017, http://www.nicci.org/pdf/Top 5 countires of FDI Commitments in Nepal-FYwise and countrywise for 5 years +9months - 2011-12 to 2016-17 (9 months).pdf.

272 Ministry of Commerce of People's Republic of China, National Bureau of Statistics of People's Republic of China, and State Administration of Foreign Exchange, 2011 年度 中国对外直接投资统计公 报 2011 Statistical Bulletin of China's Outward Foreign Direct Investment (China Statistics Press, 2012), http://images.mofcom.gov.cn/hzs/201309/20130923082710756.pdf. 
For the Kruskal-Wallis test for FDI, the variables are categorized as follows:

1. Foreign Direct Investment (FDI): FDI from China is coded as "China FDI"; FDI from India is coded as "India FDI."

2. Time: The three times periods were assigned the following -1 for pre-, 2 for during, and 3 for Post-critical juncture. Time is coded as "juncture point."

In this test, the FDI depended upon the IV (sub-systemic rivalry) expressed in the form of categorical variable time expressed as juncture point. The basic logic of using this test is to decipher if there are changes in FDI patterns between India and China pre, during, and post critical junctures. Since FDI as an indicator for this dissertation only includes FDI inflows into Nepal from China and India, the categorical factor with reference to direction as used for trade is not necessary.

The KWT was run on SPSS 22 with FDI as the dependent variable, with time (expressed as juncture point) as the independent variable. The results of the KWT for FDI show non-significance. The differences in FDI from India and China into Nepal over the years of the critical junctures is not statistically significant. As per the detailed results in Appendix 2, the p-value for China FDI is 0.581 and that for India FDI is 0.689. As such, FDI is not statistically significant when comparing its inflows into Nepal from China and India before, during, and after the critical junctures.

Despite no statistical significance, Figure 16 reveals a peculiar trend for FDI. One aspect of the study revealed that the means of FDI for India and China during the three time periods, specifically that India's mean investment pattern during the critical juncture is higher that the pre- and post- periods. Referring to the Descriptive Statistics for FDI in 
Appendix 4, India's mean for FDI for the "During" period is 90.3100, which is noticeably higher than the means for the Pre (21.10) and Post (8.01) periods. As for China, it showcases a steady pattern without any marked changes in FDI outflow into Nepal; the Pre (33.89) mean is slightly higher than the During (23.85) and a bit more than the Post (20.96) means for FDI inflows into Nepal. Nevertheless, it supports the idea that India is perhaps concerned regarding increased Chinese influence and is responding through increased FDI.

Figure 16: Indian and Chinese FDI in Nepal

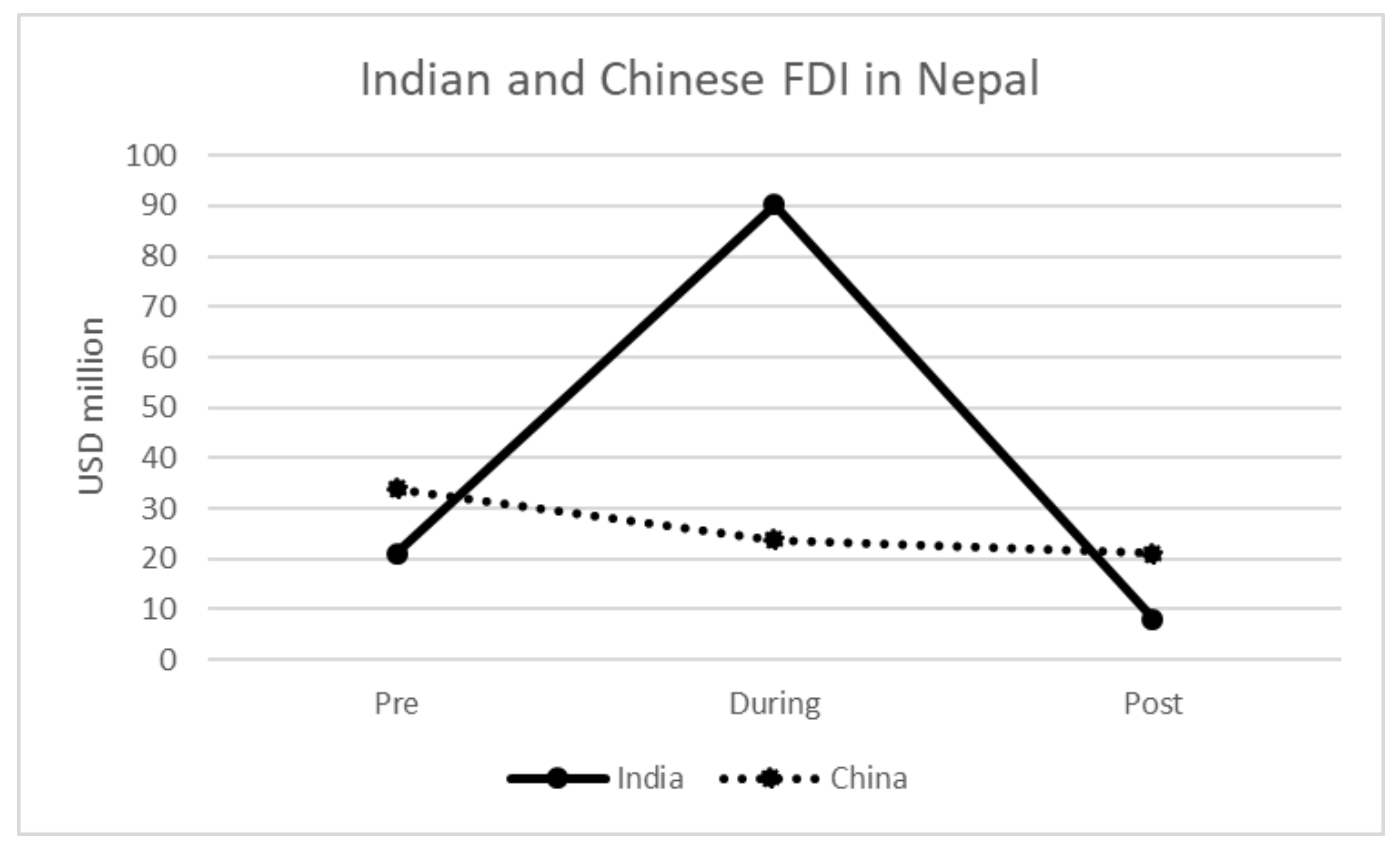

Figure 16 displays the patterns in means of FDI between India and China in Nepal during the three time periods. Although China's FDI patterns are not starkly noticeable, India's FDI to Nepal rose by approximately 328 percent from the pre to the during critical juncture period. It dropped off in post period by 91.1 percent. The pattern in FDI showcases 
that India's FDI strongly peaks during critical juncture periods and is a peculiar trend within this variable while China's FDI decreases slightly during the critical junctures.

\section{Foreign Aid}

Foreign aid, which is a broad concept, entails facilitation of economic development, alleviation of poverty, and improvement of human welfare. ${ }^{273}$ The Organisation for Economic Co-operation and Development (OECD) defines Official Development Assistance (ODA) as "government aid designed to promote the economic development and welfare of developing countries. Loans and credits for military purposes are excluded. Aid may be provided bilaterally, from donor to recipient, or channeled through a multilateral development agency such as the United Nations or the World Bank." ${ }^{274}$ Broadly speaking, ODA includes development assistance from economically developed states to those that are considered developing states. It excludes military assistance, which can sometimes be packaged as foreign aid. For the purpose of this dissertation, foreign aid will exclude military assistance, as is usually case for calculating ODA. Additionally, security allocations are extremely sensitive in Nepal's case given its proximity to both India and China. Additionally, "softer" forms of military aid can translate to uses that have

${ }^{273}$ Ministry of Commerce of People's Republic of China, National Bureau of Statistics of People's Republic of China, and State Administration of Foreign Exchange, 2011 年度 中国对外直接投资 统计公 报 2011 Statistical Bulletin of China's Outward Foreign Direct Investment (China Statistics Press, 2012), http://images.mofcom.gov.cn/hzs/201309/20130923082710756.pdf.

274 “Net ODA,” OECD Data, 2017, https://data.oecd.org/oda/net-oda.htm. 
implications for more "harder" forms of military action. ${ }^{275}$ As such, military aid is not included in the analysis.

Just like FDI, foreign aid can be tied to numerous motives. While humanitarian in nature, foreign aid can be used for strategic purposes. The Marshall Plan after WWII entailed rebuilding European partners such as Germany, Italy, and France to enhance trade between the US and those countries; as such, US motivations for foreign aid were not exclusively borne out of humanitarian necessity. ${ }^{276}$ Strategic interests of the US underpinned its foreign aid initiatives. In 2002, President George W. Bush increased the ODA by 50 per cent in core development assistance - an annual increase of $\$ 5$ billion; the logic was to promote a development "from the bottom up" to stem recruitment for terrorist groups. ${ }^{277}$ While the US, Japan, and the European Union states have been at the forefront of foreign aid, be it in the form of direct or indirect ODA, the economic growth of China and India have led to their increasing interest in the strategic use of foreign aid.

China is now considered part of the "emerging donors" group that is making inroads into areas of the developing world that had long depended on multilateral aid and loans from organizations such as the IMF and the World Bank. What China offers is a new line of debt and many times, debt forgiveness; this is especially true for countries in Africa

${ }^{275}$ Reeves, "China's Self-Defeating Tactics in Nepal," 527;

In 2010, the Chinese Embassy in Kathmandu arranged a \$10 million grant for the purchase of riot shields and batons (from China) to bolster the riot control capabilities of the Nepali Police. The Nepali Police has long been at the front lines in the control of Tibetan refugees living in Nepal who routinely protest in front of the Chinese embassy in Kathmandu. The grant was provided to provide better equipment for the Nepali Police but the true intent was to bolster the capability of the personnel to control protesting Tibetan refugees.

${ }^{276}$ Daniel Runde, "Foreign Aid Is about U.S. Interests," Foreign Policy, 2017, http://foreignpolicy.com/2017/06/26/foreign-aid-is-about-u-s-interests-marshall-plan/.

${ }^{277}$ Ibid. 
where China has made immense investments in oil, gas, and mineral extraction activities. ${ }^{278}$ China has increasingly styled itself as a non-interventionist development partner - the "no strings attached" approach focuses on commercial ties and does not underpin aid to domestic political contexts, which had long been a major hallmark of ODA from the West. $^{279}$

The most glaring evidence of massive Chinese foreign aid is the Belt and Road Initiative (BRI). It includes a \$1 trillion commitment in Eurasia, spanning more than 60 countries. ${ }^{280}$ In Pakistan alone, the investment commitments from China is projected to be around $\$ 46$ billion. The BRI is a major strategic plan of China as it seeks to promote the old Silk Road and maritime routes; it entails major FDI into states in Eurasia but also includes foreign aid and loans. Nepal's entry into the BRI in 2017 is projected to lead to an increase in Chinese aid and investment into the country, tied to Nepal's economic diversification efforts and its push to graduate from being a least developed country (LDC) to a middle-income country before $2030 .{ }^{281}$ In essence, Chinese foreign aid in Nepal is in the upswing and remains a major factor in deciphering how it impacts the buffer system;

278 "Presidents Bush, Chirac Announce Recent Increases in Aid to Conference on Financing Development," United Nations Press Release, 2002, http://www.un.org/press/en/2002/dev2388.doc.htm.

${ }^{279}$ Sarah E. Kreps and Gustavo A. Flores-Macias, "No Strings Attached? Evaluating China's Trade Relations Abroad," The Diplomat, 2013, https://thediplomat.com/2013/05/no-strings-attachedevaluating-chinas-trade-relations-abroad/.

${ }^{280}$ Ibid.

${ }^{281}$ Jane Perlez and Yufan Huang, "Behind China's \$1 Trillion Plan to Shake Up the Economic Order," The New York Times, May 13, 2017, https://www.nytimes.com/2017/05/13/business/china-railwayone-belt-one-road-1-trillion-plan.html. 
this is especially important for India as it was outdone by China for the first time in its ODA commitment to Nepal. ${ }^{282}$

India, too, has maintained a strong regional regime of foreign aid in South Asia, a region it has long considered its strategic backyard. Given this predicament, India's foreign aid in South Asia has been largely strategic with assistance focusing on technical and economic cooperation. In 2015-16, about 74.6 percent of India's total foreign aid budget was pledged for Bhutan, followed by 9.1 percent for Afghanistan, 6.6 percent for Sri Lanka, 4 percent for Nepal and 2.8 percent each for Bangladesh and Maldives. ${ }^{283}$ It continued to favor South Asian states as the destination for a majority of its foreign aid in 2016-17, with Bhutan still maintaining first position. ${ }^{284}$ In essence, India's foreign aid is tied to its strategic interests in its neighborhood, a factor that is crucial in understanding the dynamics within the buffer system.

For the dependent variable relevance of buffer state, "foreign aid" is used as one indicator; ${ }^{285}$ the independent variable sub-systemic rivalry is coded into two categorical factors:

${ }^{282}$ Ashutosh M. Dixit, “China's Belt and Road Comes to Nepal,” The Diplomat, 2017, https://thediplomat.com/2017/07/chinas-belt-and-road-comes-to-nepal/.

${ }^{283}$ Sachin Parashari, “China Pips India in Aid to Nepal; Delhi Out of Top Five Donors' List," The Times of India, May 10, 2016, https://timesofindia.indiatimes.com/india/China-pips-India-in-aid-to-NepalDelhi-out-of-top-five-donors-list/articleshow/52180744.cms.

${ }^{284}$ Preety Bhogal, "The Politics of India’s Foreign Aid to South Asia,” Global Policy, November 2016, http://www.globalpolicyjournal.com/blog/07/11/2016/politics-india's-foreign-aid-south-asia.

${ }^{285}$ Foreign aid data was collected from the following sources:

Axel Dreher, Andreas Fuchs, Bradley Parks, Austin M. Strange, and Michael J. Tierney, “Aid, China, and Growth: Evidence from a New Global Development Finance Dataset," AidData, Working Paper \#46, 2017.

"Notes on Demands for Grants (2000/01, 2001/02, 2002/03, 2003/04, 2004/05, 2005/06, 2006/07, 2007/08, 2008/09, 2009/10, 2010/11, 2011/12, 2012/13, 2013/14, 2014/15, 2015/16, 2016/17, and 2017/18)," Ministry of Finance, Government of India, http://indiabudget.nic.in. 
For the Kruskal-Wallis test for foreign aid, the variables are categorized as

follows:

1. Foreign aid: FDI from China is coded as "China Aid"; FDI from India is coded as "India Aid."

2. Time: The three times periods were assigned the following -1 for pre-, 2 for during, and 3 for post-critical juncture periods. Time is coded as "juncture point."

Due to the sensitive nature of foreign aid in the INCBS, pledges of foreign aid are used instead of actual disbursement due to the public nature of announcements of the former. Accurate data on actual disbursement was hard to obtain due to the lack of oversight of the projects covered by the foreign aid.

The Kruskal Wallis Test for foreign aid, just like Trade and FDI, did not yield any statistical significance. The test showcases that there is no statistical significance for aid. The significance values of 0.953 for China Aid and 0.784 for India FDI, as per Appendix 2, showcase that the KWT for foreign aid are not statistically significant. These significance levels are higher than the p-value of 0.05 , which renders them statistically insignificant. Overall, foreign aid is statistically insignificant when it comes to variations across time.

Vipul Vivek, "India Gives Most Foreign Aid to Bhutan, Bot Its New Priorities Afghanistan and Africa," Scroll, 2017, https://scroll.in/article/835481/india-gives-most-foreign-aid-to-bhutan-not-its-newpriorities-afghanistan-and-africa.

Agence France-Presse and Staff, "Nepal Donors Pledge \$3bn for Rebuilding in Aftermath of Earthquakes," The Guardian, 2015, https://www.theguardian.com/global-development/2015/jun/25/nepalearthquakes-3bn-aid-pledge-international-donors-kathmandu.

"Narayani Basu, "Nepal-China-India: Three's a Crowd?," The Diplomat, 2017, https://thediplomat.com/2017/08/nepal-china-india-threes-a-crowd/. 
Despite the statistical insignificance of foreign aid figures, Figure 17 showcases a dynamic pattern based on descriptive statistics. ${ }^{286}$ The pre- and post-critical juncture figures have a sharp uptick for China, while there is an upward trend for the during critical juncture period for India. This showcases trends in foreign aid that showcase fluctuations in figures related to India and China. It is particularly important to note that Chinese figures for foreign aid overshadow Indian commitments. While India's trends are more or less steady, China showcases extensive activity around the critical juncture points.

Figure 17: Foreign Aid from China and India for Nepal

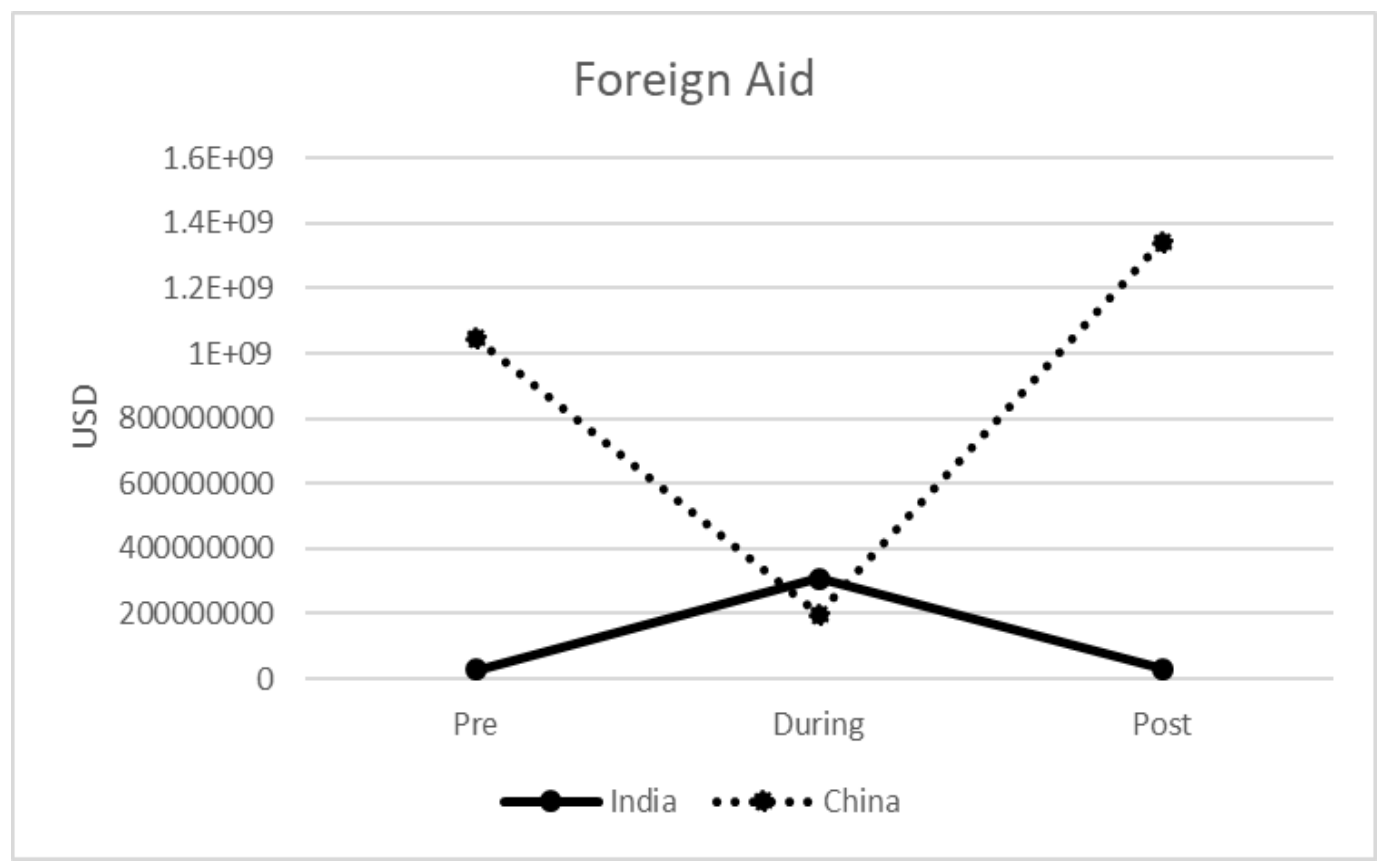

${ }^{286}$ Refer to Appendix 5 for the descriptive statistics for foreign aid. 
This pattern deciphered from foreign aid showcases that there is indeed interactions at the critical juncture; while China's aid dips at the critical juncture, India's increases. Also, there is a sharp increase in the post-critical juncture period for China's foreign aid into Nepal. As such, intensification of sub-systemic rivalry cannot be ruled out given the dynamic decrease and increase in China's foreign aid into Nepal.

The quantitative data analyses carried out for trade, foreign direct investment, and foreign aid showcase no statistical significance. The non-parametric Kruskall Wallis Test for the datasets reveal that there are no statistically significant variations in the pre-, during, and post-data for the three indicators when they are split into sub-datasets for India and China. To simply put, the statistical significance for the Kruskall Wallis Tests carried out for each of the indicators is above the p-value of 0.05 . This renders them statistically insignificant. However, a closer look at the descriptive statistics of the indicators reveals patterns that are not captured through the significance levels. As showcased in Figure 18, ${ }^{287}$ the patterns for data for trade, FDI, and foreign aid showcase significant dynamics in data between India and China's engagement with Nepal. This is particularly pronounced for FDI and foreign aid, which show interacting effects and as such, important dynamics for their role in deciphering the research question.

${ }^{287}$ For Figure 18, refer to page number 151. 
Figure 18: Comparative Trends in Analysis of Material Engagement
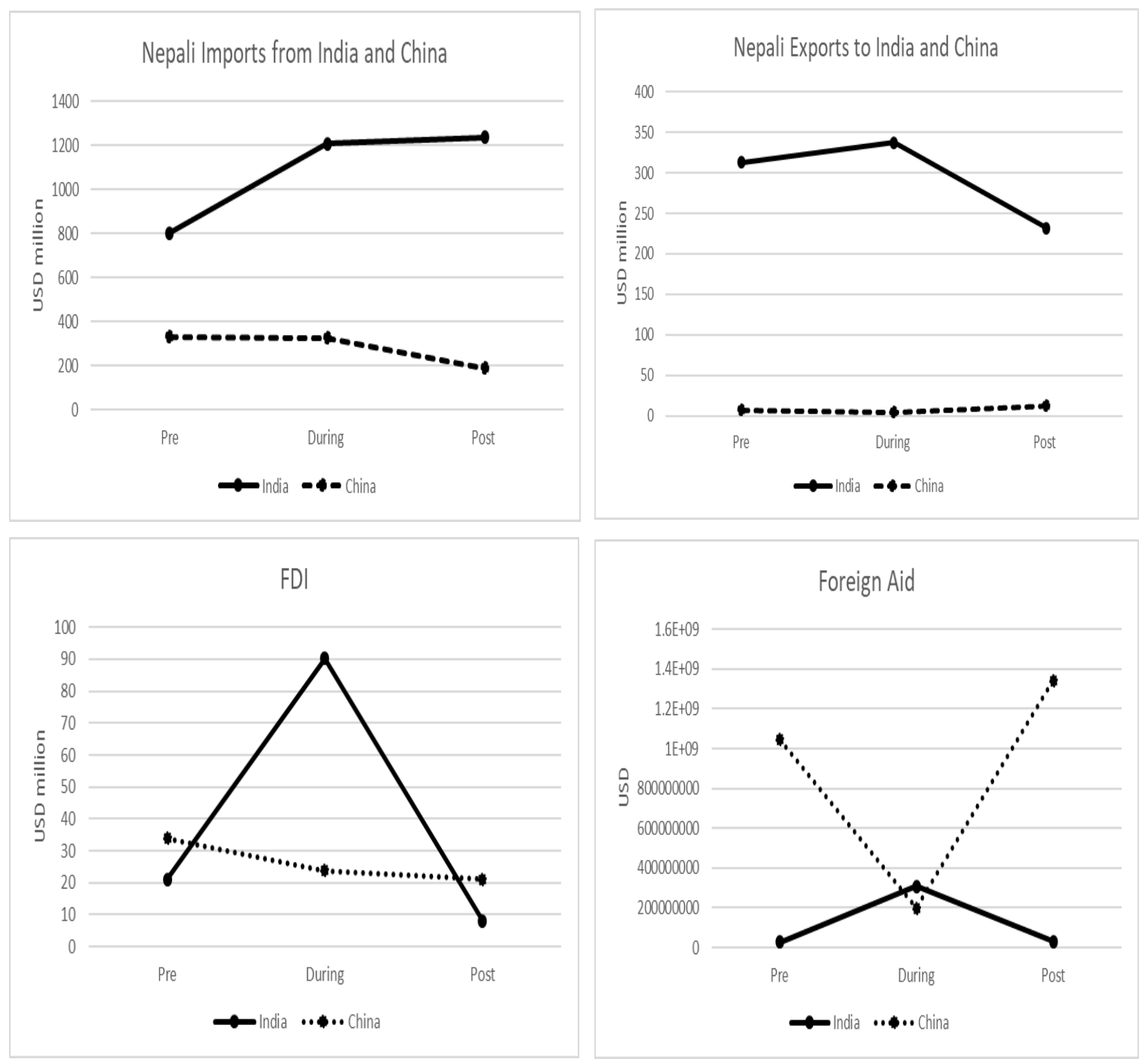

The mean figures for trade, foreign aid, and FDI pre-, during, and post-critical junctures are not statistically significant when the data are tested by KWT. However, it can be deciphered from Figure 18 that the extent to which Nepal trades with India is much more substantial than its trade with China. As for FDI, the mean figure "during critical juncture" for India is much higher than pre and post periods; it will require backing of the qualitative data to ensure that India is indeed active during critical junctures in Nepal's 
affairs. As for China, the changes in FDI with time are not substantial. The plot for foreign aid in Figure 18 displays a fascinating dynamic; here, China's means for aid show dynamic changes along the time periods. There is substantial mean difference between the during period and the pre and post periods. The important aspect of this dynamic is that these are based on foreign aid commitments and not disbursements; as such, the data needs to be complemented with the other half of the Convergent Parallel Design to ensure that there are intensified Chinese activities in the pre and post periods of the critical junctures.

\section{Non-Parametric Correlations}

The results for the non-parametric correlations conducted in SPSS are characterized by patterns of change that may signal increased strategic interest in Nepal from China and India, particularly in terms of material engagement. ${ }^{288}$ The variables are coded as the following:

1. Trade: Nepal's imports from China is coded as "China Imports"; Nepal's exports to China is coded as "China Exports". Similarly, Nepal's imports from India is coded as "India Imports"; Nepal's exports to India is coded as "India Exports".

2. Foreign Direct Investment (FDI): FDI from China to Nepal is coded as "China FDI"; FDI from India to Nepal is coded as "India FDI".

3. Foreign Aid: Foreign aid from China to Nepal is coded as "China Aid"; foreign aid from India to Nepal is coded as "India Aid".

\footnotetext{
${ }^{288}$ For the results of the non-parametric correlations, refer to Appendix 6 on page number 218.
} 
4. Time: The pre-, during, and post-critical juncture periods are collectively coded as "Juncture Year".

The results are characterized by several statistically significant correlations. The correlations between "China Imports" and "India Imports", "China Imports" and "India Exports", "China Imports" and "India FDI", "China Imports" and "China Aid", "China Imports" and "India Aid", as well as "China Imports" and "Juncture Year" were statistically significant. "China Exports" did not display statistical significant in correlations with any of the other variables used. The correlations between "India Imports" and "India Exports", "India Imports" and "India FDI", "India Imports" and "China Aid", "India Imports" and "India Aid", as well as "India Imports" and "Juncture Year" showcase statistical significance.

Additionally, correlations between "India Exports" and "China Aid" as well as "India Exports" and "Juncture Year" display statistical significance. The correlations between "India FDI" and "China FDI" and "China FDI" and "Juncture Year" are statistically significant. Furthermore, correlations between "India FDI" with "China Aid", "India Aid" and "Juncture Year" are statistically significant. Correlations between "China Aid" and "India Aid" as well as "Juncture Year" are statistically significant. Finally, correlation between "India Aid" and "Juncture Year" is statistically significant. 


\section{Qualitative Data Analysis}

As the main logic of using qualitative data analysis is to decipher whether there is increase/decrease in rhetorical engagement by India and China in Nepal, data released by India and China were used for this dissertation as they signaled their increased (or decreased) interactions with the Government of Nepal (GoN). As such, Nepal's official statements are not included; instead, official rhetorical statements from India and China concerning their relations with Nepal were analyzed.

The qualitative data analysis includes official documents published by India and China regarding their relations with Nepal. They included the following data from the Ministry of External Affairs (MEA) of the Republic of India, Ministry of Foreign Affairs of the People's Republic of China (MoFAPRC), and the Ministry of Foreign Affairs of the Federal Democratic Republic of Nepal (MoFAN):

- Unilateral statements from India or China regarding their relations with Nepal or developments within Nepal; these included official press releases and media briefings organized by the respective institutions in India and China that deal with foreign affairs.

- Joint agreements/statements/treaties/Memorandum of Understanding (MoU) signed between Nepal-India and Nepal-China.

- Official statements or speeches released by the respective institutions of China and India 
For India, the data were collected from the Media Center of the Ministry of External Affairs, the Government of India and the Embassy of India in Kathmandu, Nepal. ${ }^{289}$ The data included all qualitative data available from the Ministry and Embassy's website available as of February 2018, including press releases, bilateral/multilateral documents/declarations, treaties and Memoranda of Understanding (MoUs), and media briefings.

For China, the data were collected from the website of the Embassy of the People's Republic of China in the Federal Democratic Republic of Nepal and the Ministry of Foreign Affairs of the People's Republic of China (MoFA). ${ }^{290}$ Just like for India, the qualitative data for China-Nepal interactions included all the materials collected from the MoFA and Embassy's website, including press releases, media briefings (in the form of Foreign Ministry Spokesperson's Remarks), bilateral/multilateral documents/declarations, treaties, and Memoranda of Understanding.

As part of the Content Analysis process, the collected qualitative data were analyzed using the Word Frequency Query and the Word Search Query. The Word Frequency Query helped in deciphering overarching themes and their patterns of change in the pre-, during, and post-critical juncture periods. The Word Search Query, on the other hand, helped decipher whether the rhetorical engagements between India-Nepal and China-

${ }^{289}$ Media Center, Ministry of External Affairs: Government of India, http://mea.gov.in/index.htm; Embassy of India in Kathmandu, Nepal, http://www.indianembassy.org.np/.

${ }^{290}$ Ministry of Foreign Affairs of the People's Republic of China, http://www.fmprc.gov.cn/mfa_eng/;

Embassy of the People's Republic of China in the Federal Democratic Republic of Nepal, http://np.china-embassy.org/eng/ 
Nepal were based on positive or negative affirmations. The collected qualitative data were coded based on their source country i.e. India and China; further coding was conducted by designating the statements based on their pre, during, and post-critical juncture years. Thus, this component of the convergent parallel design incorporates the rhetorical engagement aspect of sub-systemic dynamics.

\section{Word Frequency Query}

The collected qualitative data were uploaded to NVivo 11, a powerful analytical program for qualitative research. Simple word count queries were run initially to provide a sense of the overarching themes in the pre-, during, and post-critical juncture periods. These queries relayed and emphasized specific rhetorical patterns based on recurring terminologies and themes. To further streamline the process, "the Word Stop List" was applied, which is a feature of NVivo used to leave out words that added no significance to the project. ${ }^{291}$ Additionally, the word frequency query was run using the specific "with synonymous group" mode to ensure that words with the same or similar meanings were lumped together to prevent redundancy. The five most frequently used terms are displayed in Table 3, based on weighted percentage.

${ }^{291}$ The Word Stop List includes proper nouns, propositions, and pronouns. 
Table 3: Results of the Word Frequency Queries ${ }^{292}$

\begin{tabular}{|l|l|l|l|l|}
\hline & PRE & DURING & POST & OVERALL \\
\hline All data & Cooperation & Development & Development & Cooperation \\
\hline & Development & Assistance & Visit & Development \\
\hline & Visit & People & Assistance & Visit \\
\hline & Cultural & Relations & Cooperation & People \\
\hline & People & Cooperation & People & Economic \\
\hline India-Nepal & Cooperation & Development & Development & Cooperation \\
\hline & Development & Assistance & Visit & Implementation \\
\hline & Joint & Projects & Assistance & Visit \\
\hline & Visit & Issues & Projects & Development \\
\hline & Cultural & Visit & People & Affairs \\
\hline China-Nepal & Cooperation & Cooperation & Development & Support \\
\hline & Support & Development & Visit & Cooperation \\
\hline & Development & Friendly & Assistance & Development \\
\hline & People & People & Projects & Relations \\
\hline & Relations & Relations & People & People \\
\hline
\end{tabular}

Table 3 highlights the top five results of the word frequency queries that were run on NVivo. The table includes the top five words based on weighted percentage, which is defined as the frequency of a word relative to the other words counted during the query. In essence, each terminology includes the term itself and its synonyms, which are counted together to prevent redundancy. The data reveals an overwhelming emphasis on the importance of cooperation and development, which affirms the self-portrayal of both India and China as close cooperative development partners with Nepal.

In the overall data, cooperation dominates the overall discourse, followed by development, visit (which includes diplomatic exchanges), people (referring to people to people exchanges and the emphasis on the goodwill of the people), and economic ties. Overall, the qualitative data from official sources in India and China showcase a strong

${ }^{292}$ Refer to Appendices 7-18 for the Word Clouds for Table 3. 
emphasis on bilateral cooperation, which includes the significant role of development concerns given Nepal's heavy reliance on external donors.

The word frequency queries of data coded into the pre-, during, and post- periods of the critical junctures also showcased similar results. The qualitative data from the precritical juncture period showcased the same trend as the results for overall data; cooperation and development were the two major themes in the rhetoric. Interestingly, it was the only time period that "cultural" was one of the top five frequently used terms when compared to other words. Nevertheless, cooperation and development were central in pre and during critical juncture periods, with "visits" becoming more prominent in the post-critical juncture period.

For the data dealing with Indo-Nepali relations, the overall emphasis was once again, on cooperation but implementation was also emphasized. The comparison of the word frequencies in the pre-, during, and post-critical juncture periods showcase the importance of development and cooperation as well as assistance. However, a consistent term that appeared in the top five was "visit" given India's longstanding exchange of official visits with Nepal. The word becomes more prominent in the post-critical juncture period and takes a dip in the during-critical juncture period. It can be deciphered that the emphasis of official visits become more prominent after the critical juncture has passed, perhaps to recuperate India's interests in Nepal; this is supported by the fact that "visit" drastically jumps in the post-critical juncture period as compared to during such periods. While it does not appear in the overall word frequency query, the word "cultural" appears in the pre-critical juncture period - a reminder of the close cultural affinities shared by Nepal with India. However, it does not appear to be a strong factor in the other two periods. 
The word frequency query for the qualitative data for China-Nepal also showcases similar trajectories to the results for the data on Indo-Nepal relations. Overall, support, cooperation, and development are heavily emphasized. However, "people" is more prominently present than in the data for India-Nepal; in fact, it is present in the top five words for all of the periods assessed. Also, the occurrence of "friendly" during the critical juncture period is strategic given the volatility of such periods in bilateral relations. The word "visit" also appears to be significant in the post-critical juncture period, as it is not found to be extensively used in the pre- and during- periods. As such, it can be deciphered that China also emphasizes official visits in the post-critical juncture period given that the other time periods overwhelmingly emphasize cooperation and development.

\section{Text Search Query}

After the initial simple word frequency query, the text search query was used. This query can help decipher the trends in the collected qualitative data. The text search query used two word dictionaries for positive and negative affirmations to analyze what rhetorical trends exist in the bilateral relations between India-Nepal and China-Nepal. ${ }^{293}$ The word dictionaries are based on similar themes; in this case, they are positive and negative bilateral interactions. The idea is to decipher if there are differences in trends in interactions

${ }^{293}$ Dictionary for positive affirmation: coop* OR agree* OR friend* OR help* OR aid* OR dona* OR "people to people" OR affinity OR engag* OR connect* OR assist* OR collaborat* OR partner* OR harmony OR reciproc* OR ally OR alliance;

Dictionary for negative affirmation: critic* OR condemn* OR cancel* OR disapprove OR rebuk* OR reprehen* OR denounc* OR "gravely concerned" OR autocract* OR cancel* OR "oppose" OR condemn OR criticize OR criticism OR disapproval OR rebuttal OR "human rights abuse" OR "deeply concerned" 
between India-Nepal and China- Nepal; the usage of these dictionaries for this Query will also help track any changes in rhetorical themes in the three periods associated with the critical junctures. These queries also include wildcard characters, which are root words that are incomplete but allow different variations of the same word to be counted in the analysis. For example, using engag* as a part of the text search query in NVivo for the positive affirmation dictionary covers words with the root engag, such as engagement, engagement, engaging, and the like. Figures 19, 20, and 21 showcase the results for the Text Search Queries.

Figure 19: Results for the Text Search Queries for Positive Affirmations of all Qualitative Data

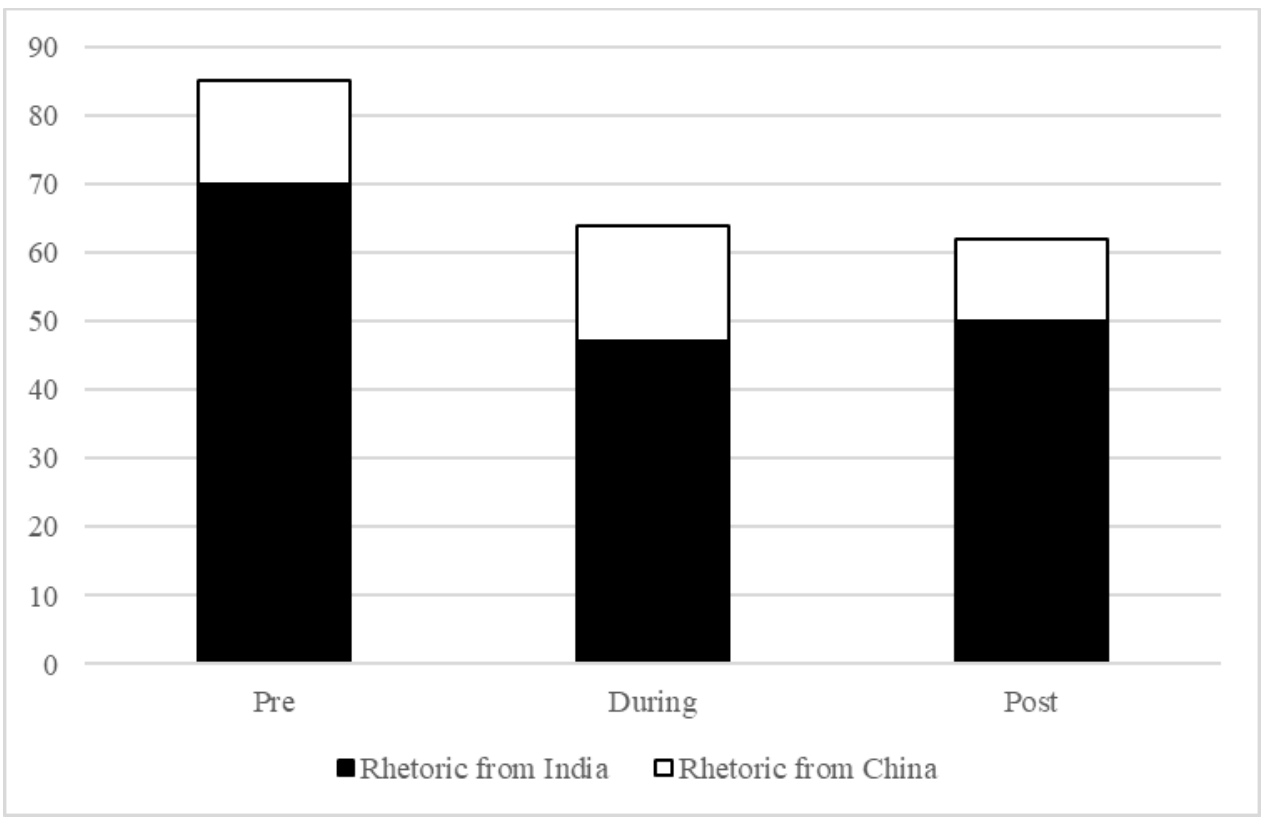


Figure 20: Results for the Text Search Queries for Negative Affirmations of all Qualitative Data

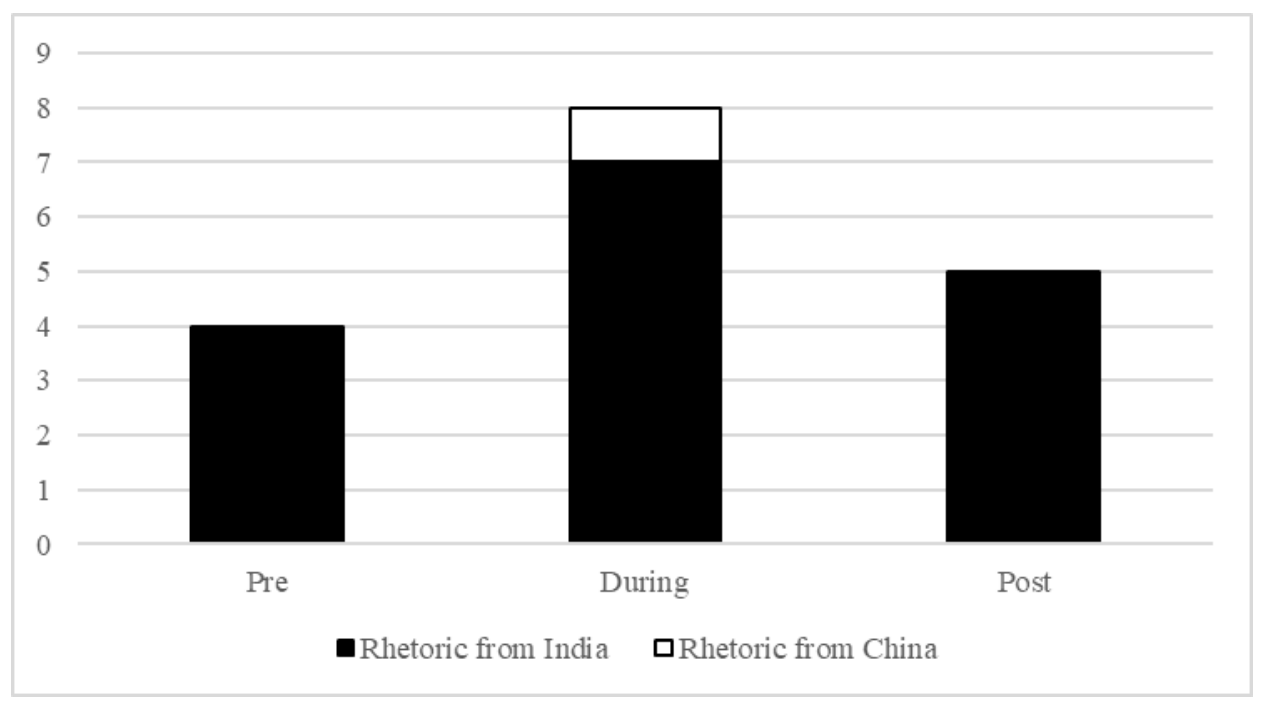

Figure 21: Comparison of Text Search Queries for Positive and Negative Affirmations

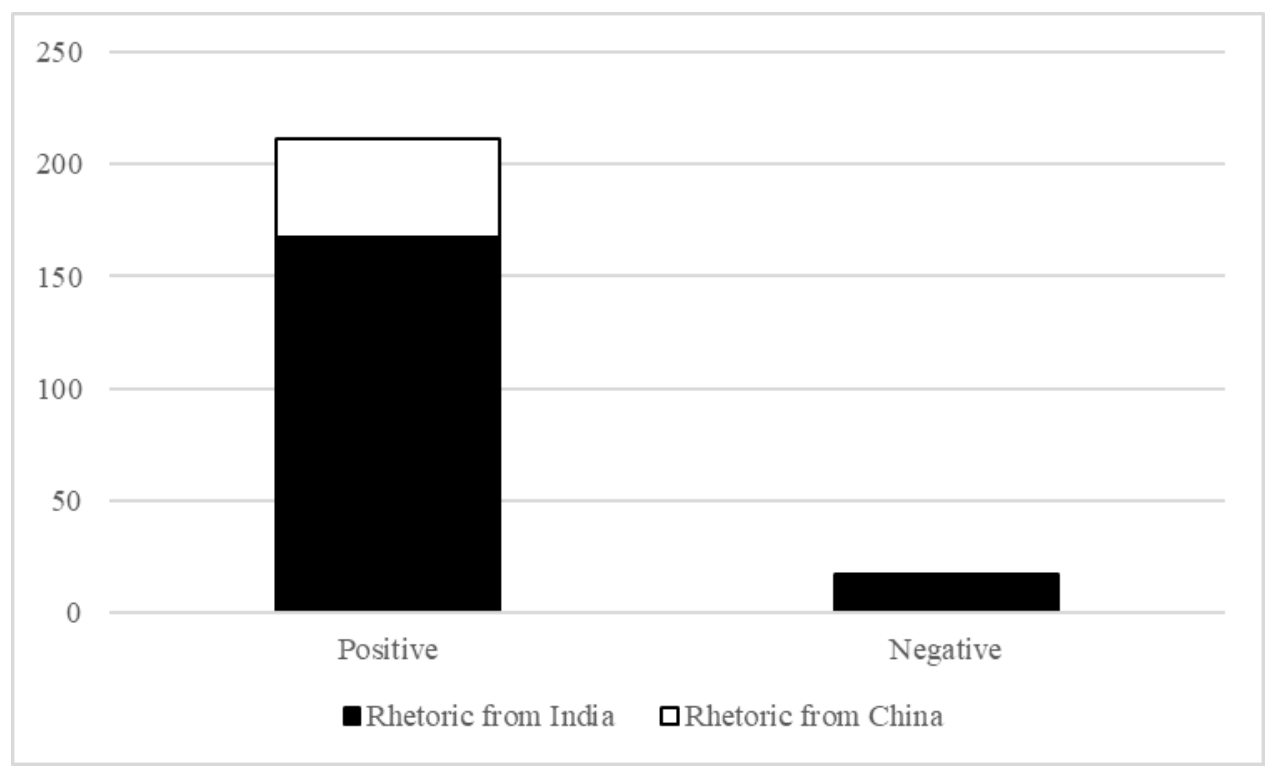


As per the results of Figures 19, 20, and 21, the positive and negative engagements of India with Nepal are much more extensive than that between China and Nepal. These figures display the number of times the terms included in the positive and negative dictionaries appear in the Text Search Query. The application of the dictionary "Positive Affirmation" yields the result that the positive rhetorical engagement between India and Nepal decreases during the critical juncture period and slightly increases after. Nevertheless, India maintains extensive rhetorical engagement with Nepal when compared to China.

There are no significant differences in positive rhetorical engagement between China and Nepal in any of the periods. However, the extent of engagement in terms of the rhetoric from China is much more limited when compared to the data for the rhetoric from India, as displayed in Figures 19, 20, and 21.

The application of "negative affirmation" yielded very different results. Negative rhetorical engagement increased during the critical juncture period for the case of IndiaNepal. As for China, it is almost absent in all of the cases with a slight increase during the critical juncture. Figure 19 showcases that negative affirmation is significantly lower than positive affirmation in the overall analysis of the qualitative data, signaling that public diplomacy is overwhelmingly devoid of direct negative connotation, especially in the case of India and China's engagement in Nepal. However, India is more willing to use such rhetoric, particularly during periods of critical junctures.

Overall, the text search queries showcase that India is more engaged when it comes to making public rhetorical statements, in instances of both negative and positive affirmations. Positive affirmations from India subside slightly during critical junctures and 
pick up slightly after. While negative affirmations are fewer, India is more forthcoming in their usage; such affirmations increase during critical junctures. As for China, its rhetorical engagement, at least in the public platform, is limited when compared to India. Positive affirmation does not showcase difference between periods. Notably, negative affirmation is absent in the pre and post periods, a fact that reaffirms China's non-interference policy in the internal affairs of other states, at least publicly. ${ }^{294}$

\section{$\underline{\text { Organization of Analyzed Data Results }}$}

This section is for the organization of the results of both qualitative and quantitative data, keeping in mind their connection to the research question and hypothesis. Chapter VI covers the comparison and combined interpretation of the data analyses in the context of this dissertation. The organization of the analyzed data results is for streamlining purposes, readying it for comparison and interpretation in the next chapter.

\section{Quantitative Data Analysis Results}

Quantitative data analyses results showcase that despite statistical insignificance, there are patterns that impact the increase/decrease in interest from the buffered states towards the buffer state. These patterns showcase differing and unique trajectories of

294 "Commentary: Stronger China not to Change its Non-Interference Policy." Xinhua News Agency, 15 July 2017. General OneFile, http://link.galegroup.com/apps/doc/A498554258/ITOF?u=miam11506\&sid=ITOF\&xid=16ed0ae3; China's non-interference policy is based on its foreign policy cornerstone that emphasizes cooperation over interference. The official stance in China's engagement with other states, particularly developing states, has been an emphasis on cooperation and development. As such, the official Chinese stance has always been the "respect for equality, non-interference and sovereignty." 
material engagement by India and China with Nepal. Table 4 highlights the overall quantitative trends. India's imports from Nepal increases during critical juncture periods along with Indian FDI to Nepal. As for foreign aid, China's commitments dip during critical junctures and India's spikes slights during the same period. Foreign aid from China picks up significantly in the post-critical juncture period. Table 4 highlights the major trends in quantitative data analysis of this study.

Table 4: Overall Results of the Quantitative Data Analysis

\begin{tabular}{|c|c|c|}
\hline Variable & Analysis Result & Overall Patterns \\
\hline Trade & $\begin{array}{l}\text { Statistically insignificant at the } 0.05 \mathrm{p}- \\
\text { value; } \\
\text { - } \\
\text { critical junctures } \\
\text { - } \begin{array}{l}\text { India's preponderance as Nepal's } \\
\text { major trading partner is affirmed }\end{array}\end{array}$ & $\begin{array}{l}\text { Increase in political } \\
\text { relevance of Nepal } \\
\text { for India during } \\
\text { critical junctures due } \\
\text { to rise in import } \\
\text { figures }\end{array}$ \\
\hline $\begin{array}{l}\text { Foreign Direct } \\
\text { Investment }\end{array}$ & $\begin{array}{l}\text { Statistically insignificant at the } 0.05 \mathrm{p}- \\
\text { value; } \\
\text { - Significant increase in FDI } \\
\text { from India at the critical } \\
\text { juncture }\end{array}$ & $\begin{array}{l}\text { Increase in political } \\
\text { relevance of Nepal } \\
\text { for India during } \\
\text { critical junctures }\end{array}$ \\
\hline Foreign Aid & $\begin{array}{l}\text { Statistically insignificant at the } 0.05 \mathrm{p}- \\
\text { value; } \\
\text { - Significant interactions in } \\
\text { patterns } \\
\text { - China's foreign aid is } \\
\text { extensively high at pre and post } \\
\text { periods } \\
\text { - India's is the opposite; it is } \\
\text { higher during the critical } \\
\text { juncture }\end{array}$ & $\begin{array}{l}\text { Extensively } \\
\text { interactive trajectory } \\
\text { in the } \\
\text { increase/decrease of } \\
\text { political relevance; } \\
\text { while China's } \\
\text { interest increases, } \\
\text { India's decreases } \\
\text { and vice-versa }\end{array}$ \\
\hline
\end{tabular}




\begin{tabular}{|c|c|c|}
\hline $\begin{array}{l}\text { Non- } \\
\text { Parametric } \\
\text { Correlations }\end{array}$ & $\begin{array}{l}\text { Statistically significant correlations } \\
\text { between } \\
\text { - "China Imports" and "India } \\
\text { Imports" } \\
\text { - "China FDI" and "India FDI" } \\
\text { - "China Aid" and "India Aid" } \\
\text { - "Juncture Year" with all } \\
\text { variables except "China } \\
\text { Exports" }\end{array}$ & $\begin{array}{l}\text { - Extensive increase } \\
\text { in material } \\
\text { engagement of India } \\
\text { and China with } \\
\text { Nepal vis-à-vis each } \\
\text { other with the } \\
\text { exception of "China } \\
\text { Exports" } \\
\text { - Overall increase in } \\
\text { material engagement } \\
\text { over time i.e. } \\
\text { "Juncture Year" }\end{array}$ \\
\hline
\end{tabular}

\section{Qualitative Data Analysis Results}

The qualitative data analyses also showcase interesting patterns in rhetorical engagements between India-Nepal and China-Nepal. From the importance of diplomatic visits to the overwhelming emphasis on development and cooperation, the qualitative data analyses results showcased in Table 5 infer that there are interesting dynamics at play in the INCBS. 
Table 5: Overall Results of the Qualitative Data Analysis

\begin{tabular}{|c|c|c|}
\hline $\begin{array}{l}\text { Content } \\
\text { Analysis }\end{array}$ & Analysis Result & Overall Patterns \\
\hline $\begin{array}{l}\text { Word } \\
\text { Frequency } \\
\text { Query }\end{array}$ & 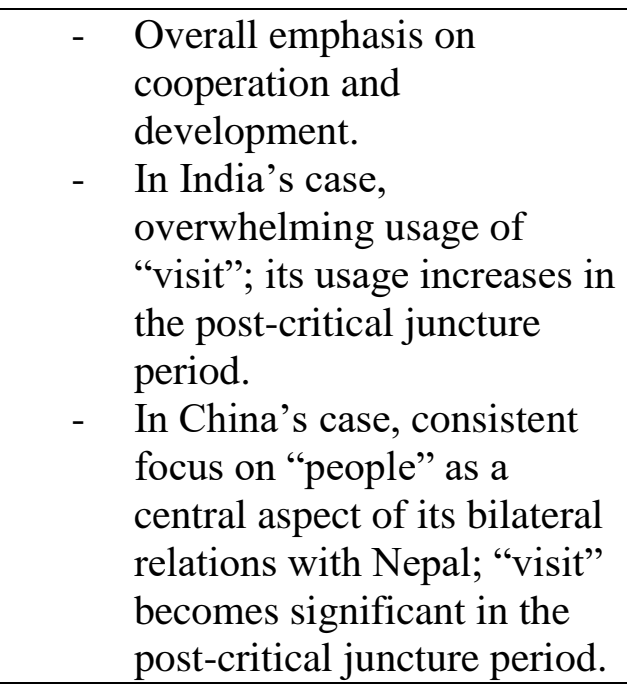 & 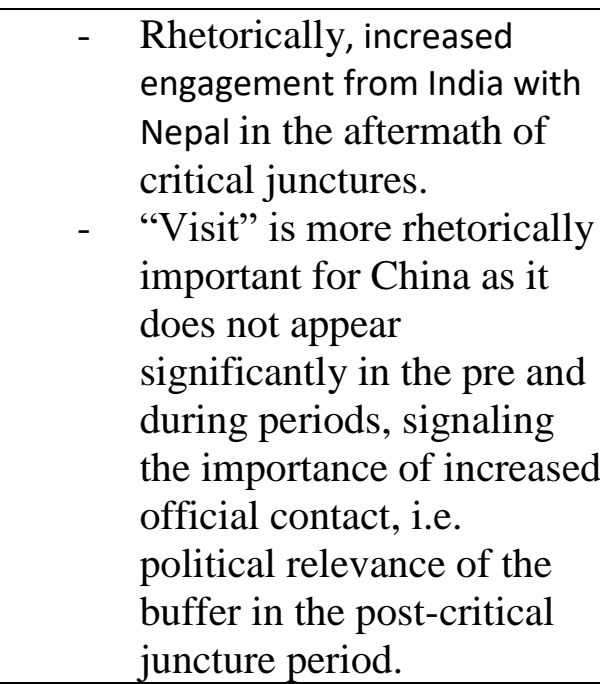 \\
\hline $\begin{array}{l}\text { Text } \\
\text { Search } \\
\text { Query }\end{array}$ & 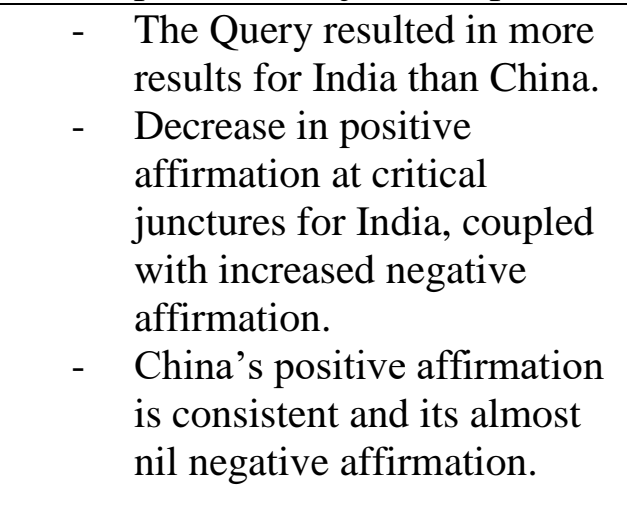 & $\begin{array}{l}\text { - Increase relevance of } \\
\text { Nepal given India's } \\
\text { increase in negative } \\
\text { affirmation and decrease in } \\
\text { positive affirmations at } \\
\text { critical junctures. } \\
\text { - Almost nil negative } \\
\text { affirmations from China, } \\
\text { signaling the importance of } \\
\text { positive rhetorical } \\
\text { engagement with Nepal. }\end{array}$ \\
\hline
\end{tabular}




\section{CHAPTER VI: COLLECTIVE INTERPRETATION OF RESULTS}

Chapter VI is focused on the collective comparison and interpretation of the results from the quantitative and qualitative analyses carried out in Chapter V within the larger framework of the research question and the hypotheses of the dissertation. This entails a collective interpretation of the mixed-method approach. This chapter explains the results of the analyses by combining them and includes the interpretation of the results to provide an answer to the research question of the proposed study. The combined interpretation is essential in deciphering whether there is convergence or divergence between the two analyses. If the results showcase extensive similarities, then there is convergence. If the results of the two methods showcase significant differences, then it is termed divergence. Either way, the combined results allow for a more complete understanding of the buffer system, including its relevance as not just a geographic discontinuity between buffered states.

First, the results from the two analyses are compared to tease out similarities and differences in results. Then, this chapter showcases how much of convergence or divergence there is in the results of the analyses. This section also merges the results; then, the results are collectively interpreted within the framework of the research question and hypothesis, highlighting whether changes in sub-systemic rivalry (based on the critical juncture time periods) will induce changes in the relevance of buffer states (increase/decrease in dependent variables; increase/decrease in rhetorical engagement). 


\section{Comparison of Qualitative and Quantitative Analyses}

The comparison of both analyses deciphers the increase/decrease in sub-systemic rivalries at critical juncture points. Tables 6 and 7 display the percentage changes in the material and rhetorical engagements of China and India with Nepal, with a focus on the critical juncture points (labeled as "during" in the tables).

Table 6: Patterns of Changes in Material Engagement ${ }^{295}$

\begin{tabular}{|l|l|l|l|c|c|}
\hline $\begin{array}{l}\text { Quantitative } \\
\text { Analysis }\end{array}$ & & & Pre & During & Post \\
\hline KWT & Trade & & & & \\
\hline & a) Exports & India & - & -3.87 & -31.31 \\
\hline & China & - & +50.8 & +161.85 \\
\hline & b) Imports & India & - & -1.36 & -42.01 \\
\hline & China & - & & \\
\hline & $\begin{array}{l}\text { Foreign } \\
\text { Direct } \\
\text { Investment }\end{array}$ & & - & & \\
\hline & & India & & +327.96 & -91.12 \\
\hline & Foreign & China & - & -29.64 & -12.1 \\
\hline & Aid & & - & & \\
\hline & & India & & +1066.5 & -90.4 \\
\hline & & China & - & -81.02 & +577.3 \\
\hline
\end{tabular}

${ }^{295}$ All numbers in Table 6 are percentages. The numbers in the "During" column are the percentage changes for trade, FDI, and foreign aid from the "Pre" to the "During" critical juncture period; similarly, the numbers in the "Post" column are the percentage changes from the "During" to the "Post" critical juncture period. 
Table 7: Patterns of Changes in Rhetorical Engagement ${ }^{296}$

\begin{tabular}{|c|c|c|c|c|c|}
\hline \multicolumn{3}{|c|}{ Qualitative Analysis } & \multicolumn{3}{|c|}{ Time } \\
\hline & & & Pre & During & Post \\
\hline \multirow{2}{*}{\multicolumn{2}{|c|}{$\begin{array}{l}\text { Word Frequency Test (Overall } \\
\text { number of official statements) }\end{array}$}} & India & - & +51.6 & -34.75 \\
\hline & & China & - & +94.64 & -60.55 \\
\hline \multirow{6}{*}{$\begin{array}{l}\text { Word Search } \\
\text { Query }\end{array}$} & \multirow{3}{*}{$\begin{array}{l}\text { Negative } \\
\text { Affirmation }\end{array}$} & Overall & - & +100 & -37.5 \\
\hline & & India & - & +75 & -28.57 \\
\hline & & China & - & +100 & -100 \\
\hline & \multirow{3}{*}{$\begin{array}{l}\text { Positive } \\
\text { Affirmation }\end{array}$} & Overall & - & -24.70 & -3.125 \\
\hline & & India & - & -32.85 & +6.38 \\
\hline & & China & - & +13.33 & -29.4 \\
\hline
\end{tabular}

Tables 6 and 7 display that the link between sub-systemic rivalry and relevance of the buffer state is not as straightforward as an increase or decrease during critical juncture periods. Referring to Table 6, it can be assessed that India's material engagement with Nepal showcases a unique pattern -- the exports from Nepal to India (+7.87), imports from India to Nepal $(+50.8 \%)$, FDI from India to Nepal $(+327.96)$, and foreign aid from India to Nepal (+1066.5), all display increases during critical junctures. Coincidentally, the material engagement of China with Nepal during the critical junctures showcase decreases; Nepal's exports to China (-31.8\%), Nepal's imports from China (-1.36\%), China's FDI into Nepal (-29.64\%), and China's foreign aid to Nepal (-81.02\%) all showcase decreases, albeit the decrease of Nepal's imports from China is very slight.

296 All numbers in Table 7 are percentages. The numbers in the "During" column for the Word Frequency Test are the percentage changes for the overall number of rhetorical statements from India and China regarding Nepal from the "Pre" to the "During" critical juncture period; similarly, the numbers in the "Post" column for the Word Frequency Test are the percentage changes from the "During" to the "Post" critical juncture period.

As for the Text Query Test, the percentage changes reflect the changes in the number of terminologies based on the dictionaries for positive and negative affirmations. The percentage changes reflect the changes in the overall number of times the terms included in the positive and negative dictionaries change based on time pre-, during, and post-critical juncture periods. 
As for the post-critical juncture period, there are patterns that are quite the opposite of what happens during critical junctures. Exports from Nepal to India (-31.31\%), FDI from India into Nepal (-91.12\%) and foreign aid from India to Nepal (-90.4\%) decrease; imports from India to Nepal shows a slight increase of $+2.3 \%$. Overall, the trends are decreasing Indian material engagement with Nepal in the post-critical juncture period. During the same period, exports from Nepal to China $(+161.85 \%)$ and foreign aid $(+577.3 \%)$ showcase massive increases; imports from China (-42.01\%), and FDI from China (-12.1\%) decrease. The overall picture for India in the post-critical juncture is that of extensive decrease in material engagement with Nepal; while for China, there is some engagement but the ones that showcase increases are massive in percentage changes.

In essence, during critical juncture periods, there are dynamic sub-systemic interactions; India's material engagement is positive for all the dependent variables of the dissertation. Overall, India intensifies its material engagement with Nepal during the critical junctures. At the same time, China decreases its material engagement during this period. As for the post-critical juncture period, there is extensive decrease in India's material engagement with Nepal. As for China, it does not showcase an increase across the board but the two variables (foreign aid and exports) display significant increases. These results may indicate that sub-systemic rivalries do not always manifest during critical junctures. In fact, the post-critical juncture data analysis reveals that China's approach to engaging Nepal heavily focuses on doing so after the critical juncture, as showcased by the massive increase in foreign aid in the post-critical juncture period.

The results for the qualitative data analyses infer important trends for sub-systemic interactions. The rhetorical engagement during critical junctures increases for both India 
$(+51.6 \%)$ and China (+94.64\%) and declines in the post-critical juncture period (-34.75\% for India and $-60.55 \%$ for China). The percentage changes represent the overall changes in the number of rhetorical statements from India and China regarding their relations with Nepal.

The application of the dictionary labeled "Negative Affirmation" resulted in extensive increase for both India $(+75 \%)$ and China $(+100 \%)$. However, the small sample sizes for this measure needs to be considered when drawing inferences ( 3 for India; 1 for China). On the contrary, the results for the usage of the dictionary titled "Positive Affirmation" yields important implications. During the critical junctures, the number of terminologies that are part of the dictionary highlighting positive rhetorical engagement decreases by $32.85 \%$; at the same time, those from China increase by $13.33 \%$. The postcritical juncture period experiences a slight increase of 6.38\% for India while for China, it decreases by $-29.4 \%$. As such, the occurrence of terminologies in the qualitative data that are part of the "Positive Affirmation" dictionary increase for India by $6.38 \%$ from the during to the post-critical juncture period. As for China, there is decline for the same by $29.4 \%$.

Comparing both qualitative and quantitative analyses, there are patterns that have implications for the sub-systemic interactions between India and China. For India, material engagement with Nepal increases along with increase in negative affirmation and decrease in positive affirmation during the critical junctures. During the same period, India's rhetorical engagement increases; terms such as "development" and "assistance" are heavily used, while "visit" decreases during the same period. Thus, India's material engagement 
increases during critical junctures, while rhetorically there is an overall increase, the increase in negative affirmations is more pronounced.

During the critical juncture, China's material engagement with Nepal decreases when compared to the pre-critical juncture period. At the same time, there is also increase in rhetorical engagement with Nepal; while negative affirmation is almost nil, ${ }^{297}$ the rhetorical emphasis on positive affirmation from China increases during critical junctures. While "cooperation" and "development" are consistent in all time periods, the term "friendly" appears as the third most common terminology in official Chinese rhetoric, which does not appear in the pre- and post- periods in the top five most frequently used terms. In essence, China's material engagement decreases at critical junctures, but rhetorical engagement increases during critical junctures. Referring to Tables 6 and 7, it can be ascertained that trade, FDI, and foreign aid from China decline during critical junctures. During the same period, rhetorical statements from China regarding Nepal increased, along with the increase in terms that highlight positive relations between the two states.

The comparison for the post-critical juncture period yields a rather complex dynamic. India's material engagement with Nepal largely decreases after the critical juncture period. The overall rhetorical engagement dips as well but there is a caveat; negative affirmations decrease but positive affirmations increase during the same time period. The term "visit" increases in occurrence during this period. Overall, India's

${ }^{297}$ Refer to Figure 18 on page number 151; the increase for China's negative affirmation is by 1 while it is totally absent for other periods. 
material engagement with Nepal decrease after the critical juncture years but positive affirmations increase, along with the term "visit."

As for China, the post-critical juncture period showcases mixed results. While exports from Nepal to China increase along with increase in foreign aid to Nepal, other variables of material engagement decrease. Nevertheless, the increases in exports and foreign aid are substantial. There is also a sharp decrease in rhetorical engagement by China with Nepal, with decreases in both negative and positive affirmations. However, the term "visit" is the second most consistently used term in Chinese official rhetoric regarding its relations with Nepal, which is absent in the pre- and during critical juncture periods. Overall, the analyses showcase that China is more willing to engage materially after the critical juncture but rhetorically engagement decreases; however, "visit" becomes more prominent.

Referring to Appendix $6,{ }^{298}$ the results of the non-parametric correlations add insights into the dynamic nature of material and rhetorical engagements of India and China in Nepal. Overall, the increase in imports from China is characterized by increase in imports from India. Similarly, increases in FDI and foreign aid from China have been characterized by increases from India as well. All of these aforementioned variables also showcase increase over time. In essence, both China and India have increased their exports to Nepal along with FDI and aid over time. While these correlations do not take into account the differences in the pre-, during and post-critical juncture periods, they shed light on the increasing material commitment of India and China in Nepal.

${ }^{298}$ For Appendix 6, refer to page number 218. 


\section{Convergence/Divergence of Analyses and Merging of Results}

The analyses showcase trends in changes across the critical junctures. The comparison of the qualitative and quantitative analyses reveals patterns that are either convergent or divergent. The assessment of the convergence and divergence of the analyses is followed by merging of the results of the analyses to prepare for collective interpretation of the results.

The process of convergence/divergence in the results of the analyses is the last phase of the convergent parallel design before the collective interpretation of the results. This section discusses to what extent the results converge and diverge to relate them to each other. ${ }^{299}$ While the previous section covers the overall comparison of the two analyses, this section merges the results.

\section{Results for India-Nepal Engagements}

Overall, the results for India-Nepal engagements showcase convergence for both quantitative and qualitative approaches during and post-critical junctures. Increase in material engagement is coupled with increase in rhetorical engagement (in terms of overall diplomatic statements from India regarding Nepal). Thus, the overall material and rhetorical engagements showcase convergence. There are several caveats when the positive and negative affirmations are considered. During critical junctures, both overall material and rhetorical engagements showcase increases i.e. convergence. Positive affirmation decreases during this period for India-Nepal engagement, displaying divergence; negative

\footnotetext{
${ }^{299}$ Creswell and Clark, Designing and Conducting Mixed Methods Research, 79.
} 
affirmation increases during this period, showcasing convergence. Thus, material engagement, the total number of rhetorical statements, and negative affirmations in IndoNepali interactions affirm convergence during the critical juncture periods.

For the post-critical juncture period, there is overall convergence; decreases in material engagement are coupled with decreases in rhetorical engagement in the form of overall number of official statements from India regarding Nepal. However, there is divergence in the text search query in the form of positive affirmation; negative affirmation decreases while positive affirmation concurrently increases in the post-critical juncture years. This period is also characterized by the increase in the usage of the word "visit" and the emphasis on the theme "people" which is absent in the pre- and during critical juncture periods. Thus, material engagement, number of rhetorical statements, and negative affirmation showcase convergence during this period. Figure 20 depicts the convergence and divergence in rhetorical and material engagements of India and China with Nepal.

\section{Results for China-Nepal Engagements}

During critical junctures, overall material engagement between China and Nepal decreases while rhetorical engagement in the form of total number of governmental statements increases. Thus, there is divergence in both qualitative and quantitative approaches. Positive affirmation contributes to convergence with the overall rhetorical statements as it increases during this period, while increase in negative affirmation is almost nil. Thus, the overall results for qualitative analyses showcase convergence within qualitative indicators. But, there is no convergence between material and rhetorical engagements during the critical junctures; as such, they showcase divergence. 
As for the post-critical juncture period, the patterns of convergence and divergence are not clear. The material engagement between China and Nepal showcase divergent trajectories for trade and FDI when compared to foreign aid. ${ }^{300}$ There are increases in exports from Nepal to China and foreign aid from China to Nepal; on the contrary, imports from China into Nepal and FDI from China into Nepal decrease. ${ }^{301}$ At the same time, there is decrease in overall critical engagement between the two states. Additionally, both negative and positive affirmations also decrease during this period. The term "visit" is used extensively during this period, which does not appear in the pre and during critical juncture periods.

${ }^{300}$ Refer to Table 6 on page number 168 for details.

${ }^{301}$ Refer to Table 7 on page number 169 for details. 
Figure 20: Convergence and Divergence for India-Nepal Engagements

\begin{tabular}{|l|l|l|l|l|l|}
\hline India & During & $\begin{array}{l}\text { Increase in } \\
\text { material } \\
\text { engagement }\end{array}$ & $\begin{array}{l}\text { Increase in } \\
\text { rhetorical } \\
\text { engagement }\end{array}$ & $\begin{array}{l}\text { Increase in } \\
\text { positive } \\
\text { affirmation }\end{array}$ & Convergence \\
\hline & Post & $\begin{array}{l}\text { Decrease in } \\
\text { material } \\
\text { engagement }\end{array}$ & $\begin{array}{l}\text { Decrease in } \\
\text { regative } \\
\text { engagement } \\
\text { affirmation }\end{array}$ & $\begin{array}{l}\text { Decrease in } \\
\text { negative } \\
\text { affirmation }\end{array}$ & Divergence \\
\hline China & During & $\begin{array}{l}\text { Decrease in } \\
\text { material } \\
\text { engagement }\end{array}$ & $\begin{array}{l}\text { Increase in } \\
\text { rhetorical } \\
\text { engagement }\end{array}$ & $\begin{array}{l}\text { Increase in } \\
\text { positive } \\
\text { affirmation } \\
\text { affirmation }\end{array}$ & $\begin{array}{l}\text { Divergence } \\
\text { (Convergence } \\
\text { within } \\
\text { qualitative } \\
\text { data) }\end{array}$ \\
\hline & Post & Mixed & $\begin{array}{l}\text { Decrease in } \\
\text { rhetorical } \\
\text { engagement }\end{array}$ & $\begin{array}{l}\text { Decrease in } \\
\text { positive } \\
\text { affirmation }\end{array}$ & $\begin{array}{l}\text { Mix of } \\
\text { convergence } \\
\text { and divergence } \\
\text { (Convergence } \\
\text { within } \\
\text { qualitative } \\
\text { data) }\end{array}$ \\
\hline & & $\begin{array}{l}\text { Increase in } \\
\text { negative } \\
\text { affirmation }\end{array}$ & $\begin{array}{l}\text { (Convergence } \\
\text { within } \\
\text { qualitative } \\
\text { data) }\end{array}$ \\
\hline & & $\begin{array}{l}\text { Convergence } \\
\text { within } \\
\text { qualitative } \\
\text { data) }\end{array}$ \\
\hline & & $\begin{array}{l}\text { Decrease in } \\
\text { afitive } \\
\text { affirmation }\end{array}$ \\
\hline
\end{tabular}




\section{Collective Interpretation}

While the previous sections discuss similar or dissimilar patterns in the analyses that were carried out, the results need to be properly contextualized within the framework of this dissertation in the form of collective interpretation. While quantitative and qualitative analyses have their individual significance, the very design of the convergent parallel approach is to tap into its potential for a more complete comprehension of the topic under study, in this case the interactions of the buffered state in the buffer state. The convergent approach has the purpose "obtain different but complementary data on the same topic." ${ }^{302}$ Using both quantitative and qualitative data has allowed the injection of nuance in the understanding of how buffered states interact with the buffer state during critical junctures. The collective interpretation of the results is the final step of the convergent parallel design, which incorporates both analyses to make sense of the problem as a whole.

The collective interpretation of both data analyses for India-Nepal and China-Nepal interactions showcase distinct patterns. During critical junctures, there is an overall increase in India's material engagement with Nepal; while at the same time, there is a decrease in China's material engagement with Nepal. On the contrary, there is an overall increase in the rhetorical engagement from India while that from China decreases. During the same period, positive affirmation from India decreases with a significant increase in negative affirmation $(+75 \%) \cdot{ }^{303}$ As for China, there is a slight increase in positive affirmation despite overall decrease in rhetorical engagement, with "friendly" as a

${ }^{302}$ Morse, Janice M., \& Linda Niehaus. 2009. Mixed Methods Design: Principles and Procedures. Walnut Creek, CA: Left Coast Press.

${ }^{303}$ For details, refer to Table 7: Patterns of Changes in Rhetorical Engagement. 
recurring theme in its official statements which does not appear in pre and post critical juncture periods. Over time, China and India have increased their material commitments to Nepal, particularly in the form of FDI and foreign aid.

The interpretation has to be conducted in the context that India has traditionally been the preponderant power in Nepal, with China making inroads particularly since the 2008 riots in the Tibetan Autonomous Region. ${ }^{304}$ As such, increased/decreased material and rhetorical engagements may signal India's attempts at maneuvering Chinese endeavors into Nepal. The results from the convergent parallel design showcase two distinct trends for India and China during the critical juncture period.

\section{During-Critical Junctures}

India increases its material engagement with Nepal during critical junctures while also increasing its rhetorical engagement. It can be interpreted that India utilizes material engagement to ensure Nepal remains firmly within its sphere of influence, which has long been the traditional disposition. While rhetorical engagement increase, India also does not shy away from using harsh rhetoric in its engagement with Nepal during the critical junctures. Data for India reveal the utilization of material engagement to maintain the close nature of bilateral relationship, while deploying its rhetorical tool, including a significant increase in negative affirmation. Coupled with increase in rhetoric infused with negative rhetoric, there is also an overall decrease in the usage of positive affirmation during critical junctures. As such, India's engagement with Nepal during the critical juncture showcases

${ }^{304}$ Vidhi Doshi, "Nepal votes Thursday. China and India are Watching Closely." The Washington Post. https://www.washingtonpost.com/world/asia_pacific/nepal-votes-thursday-will-china-or-india-comeout-the-winner/2017/12/05/41473934-d550-11e7-9ad9-ca0619edfa05_story.html?utm_term=.4478f7f24ecc 
a strong material basis coupled with the confidence that negative affirmation in rhetoric will not lead to lull in relations. Given India's close ties to the political parties in Nepal and its extensive influence, negative rhetoric lends support to the fact that such public affirmations may dissuade negative implications for Indian interests in Nepal or to maintain commitment to democratization of Nepal.

China, on the other hand, engages differently with Nepal. There is an overall drop in its material engagement with Nepal during the critical juncture. Concurrently, rhetorical engagement increases, with an increase in positive affirmation. The theme "friendly" also makes headway into the five most common themes in the rhetorical statements. Thus, it appears from these analyses that China utilizes an approach that is sharply different from India's during the critical juncture. It emphasizes rhetorical engagement that has themes of mutual friendship firmly engrained in it, while de-emphasizing material relations. Also, China is careful with negative affirmations; there is only one in the data set, but that too is not directed at Nepal. As such, China remains wary of using negative affirmations in its rhetoric. In essence, it emphasizes friendship and cooperation over material engagement during the critical juncture.

Going back to the fact that India has maintained preponderance in Nepal, China's endeavors could be a means of avoiding direct confrontation with India, which emphasizes material as well as rhetorical engagement. Rhetorical engagement is less risky, and even more so due to the lack of negative affirmations - China's overtures in Nepal are delicate given India's strategic concerns. Additionally, the hesitance of China to use negative affirmations bolsters the fact that rhetoric can turn political; China is not willing to gamble in its efforts to increase its influence in Nepal. Furthermore, it is a possibility that China's 
hands-off approach to diplomacy is compromised if it uses rhetoric that is sharply critical of Nepal. Overall, during critical junctures, India and China display different trajectories in sub-systemic interactions; China's lack of negative affirmations and focus on friendly rhetoric infers wooing Nepal during the critical juncture. At the same time, its lack of material commitment showcases its understanding of India's traditional preponderance in Nepal.

\section{Post-Critical Junctures}

The post-critical juncture period is characterized by a very different trajectory of sub-systemic interactions. Contrary to the patterns during the critical juncture period, India's material and rhetorical engagement decrease; this is coupled with increase in positive affirmation and a dip in negative affirmation. The term "visit" increases in rhetorical engagement in the post-critical juncture period.

India's post-critical juncture trajectory with Nepal is characterized by relaxation of both material and rhetorical engagement. India also increases positive connotation in its rhetoric when engaging with Nepal. As such, India seems to take a more laid-back approach in material and rhetorical engagements. At the same time, as per the results of the qualitative analysis, visits figure more prominently after the critical junctures. These visits refer to diplomatic delegations exchanged between India and Nepal, as per the official documents from India included in the qualitative analysis. It can be inferred from the results of the analyses that while official statements and material commitments decrease after critical junctures, bilateral interactions remain importance. The deployment of bilateral diplomatic interactions to ensure the critical junctures do not significantly shift 
policies. Despite decrease in overall material and rhetorical engagements, India does seem to put importance on diplomatic exchange in the form of visits as a means of continuing its engagement with Nepal in the post-critical juncture period.

In the post-critical juncture period, China increases its material engagement with Nepal in the form of foreign aid and Nepal's exports to China. The latter is dependent on Nepal's own capacity, but the former could be interpreted as China's attempts at using foreign aid as a tool of influence in the post-critical juncture period, as it did in the aftermath of the earthquakes in Nepal in $2015 .{ }^{305}$ There is also a decrease in rhetorical engagement, including decrease in positive affirmation. Based on the analyses, China prefers to be selective in its interactions with Nepal, focusing on foreign aid instead of FDI after the critical juncture. Perhaps, the former has a more non-threatening tone in order to not alarm India, as China has repeatedly affirmed that both China and India need to come to an understanding over Nepal. ${ }^{306}$ Nevertheless, just like India, "visit" is a central theme in rhetorical engagement. Unlike India, which has "visit" appear consistently as one of the top five themes in its official rhetoric, it only appears in the post-critical juncture period for China. ${ }^{307}$ Official visits, captured by "visits" in the Word Frequency Query, become a prominent feature of China's relations with Nepal in the post-critical juncture period, so much so that it becomes the second most important theme after "development."

\footnotetext{
305 Chand, "Disaster Relief as a Political Tool."

306 Atul Aneja, “China Stresses on Ties with Nepal, India,” The Hindu, 2018, http://www.thehindu.com/news/international/china-stresses-on-ties-with-nepal-india/article23589865.ece.

${ }^{307}$ For more details, refer to Table 4 on page number 164: Results of the Word Frequency Queries.
} 
Thus, China's post-critical juncture approach to Nepal is nuanced. There is limited material engagement coupled with decrease in rhetorical engagement, but official visits remain important in order to ensure there is maintenance of diplomatic contact. China's post-critical juncture interactions with Nepal also showcase awareness of India's critical interests in Nepal; China deploys foreign aid instead of FDI and couples that with visits rather than official rhetoric. The selective deployment of material engagement by China supports Beijing's commitment to ensuring that India's critical interests in Nepal are considered. ${ }^{308}$ Nevertheless, China's endeavors to increase in Nepal remains a strategic reality for India.

\section{Interpretation of Overall Patterns}

The overall interpretation of the analyses showcases that India and China have distinct trajectories of engagement with Nepal. The most important inference from the convergent parallel design study is that both material and rhetorical forces operate and interact in Nepal's relations with India and China. While both powers have increased their FDI, foreign aid, and exports to Nepal over time, they showcase distinct patterns of interactions with the buffer state, both materially and rhetorically. This is especially true for China's interactions with Nepal, as showcased by its decreased material engagement during critical junctures but coupling that with softer rhetorical engagements and emphasizing mutual friendship. Both material and rhetorical engagements are

308 Aneja, "China Stresses on Ties with Nepal, India." 
characterized by fluctuations, signaling the dynamic nature of the buffer system. Overall, Chinese FDI has increased in conjunction with Indian FDI; the same is true for foreign aid The patterns of changes in FDI and Foreign aid exhibit the dynamic nature of the buffer system, given that India's FDI level during critical junctures shows massive increase; China's foreign aid dips during the critical juncture. Another peculiarity is that of the lack of negative affirmation in Chinese rhetoric, which India is not afraid to deploy, as it increases during critical junctures as showcased in Figures 19, 20, and 21. ${ }^{309}$ This is in line with China's official non-interference policy in the domestic affairs of other states.

Overall, India is less inhibited about the deployment of both material and rhetorical resources during critical junctures. It is also unafraid to use negative affirmations, which may be attributed to its increased material relations during critical junctures and its historically significant contribution to the Nepalese economy. This can be largely explained on the basis of Nepal's heavy reliance on India for trade and access to Indian port facilities. ${ }^{310}$ Additionally, the condemnation could largely be a function of India's support for democracy in Nepal, which has undergone phases of crisis. ${ }^{311}$ As such, India may feel compelled by its status as the world's largest democracy and its continued support for Nepal's democratic forces to condemn lull in democracy in Nepal; the rhetorical

${ }^{309}$ Refer to page number 160-161 for Figures 19, 20, and 21.

310 See "Nepal Trade at a Glance : Most Recent Values," World Integrated Trade Solution, 2018, https://wits.worldbank.org/CountrySnapshot/en/NPL/textview;

As of 2015 , Nepal's exports to India accounted for $63.48 \%$ of its total exports; similarly, Nepal's imports from India accounted for $60.62 \%$ of its total imports.

311 See Sandra Destradi, “India as a Democracy Promoter? New Delhi's Involvement in Nepal's Return to Democracy," Democratization 19, no. 2 (2012): 286-311, doi:10.1080/13510347.2011.584452;

SD Muni, "Royal Coup' in Nepal: Why and What Now?," Economic and Political Weekly 40, no. 7 (2005): 617-18. 
engagement is based on the fact that the material basis is propped up during the critical junctures. However, it sharply differs for China as it has not championed itself as a promoter of democracy in Nepal but has long sought to increase its presence in Nepal. ${ }^{312}$ Its strategic approach to Nepal is an acknowledgment of India's traditional preponderance in the country. Nevertheless, China's engagement is non-confrontational; it uses positive affirmation with "friendship" as a central theme during critical junctures, while India's rhetoric laden with negative affirmation increases. Also, both states utilize diplomatic visits after critical junctures, showcasing the opening up of opportunities to either continue preponderance (as is the case for India) or extend influence (as is the case for China).

The combined interpretation of both analyses showcases that material and rhetorical engagements can sometimes go hand in hand, as is the case with India's interactions with Nepal during the critical juncture when India increased material as well as rhetorical engagement but also did not shy away from harsh rhetoric during the same period. Also, they may be used in a balanced manner after assessment of their impact on bilateral relations. For example, China decreased its material commitment and rhetorical statements during the critical junctures but increased friendly rhetorical engagement. As such, Nepal as a buffer state recovers its importance as not just a geographic discontinuity between India and China. Rather, Nepal is an interactive space for the pursuit of India and Chinese interests in the form of material and rhetorical engagements. Over time, however, there is an overall increase in material engagement, as per the nonparametric correlations.

\footnotetext{
312 Monalisa Adhikari, "Between the Dragon and the Elephant : Nepal's Neutrality Conundrum," Indian Journal of Asian Affairs 25, no. 1/2 (2012): 83-97;

Madhukar S J B Rana, "China Meets India in Nepal: A Historical and Future Perspective," Indian Journal of Asian Affairs 26, no. 1/2 (2013): 59-73, doi:10.2307/43550356.
} 
FDI and foreign aid showcase increase over time. More importantly, increase in FDI from India is coupled with increase from China; the same holds true for foreign aid and exports to Nepal.

\section{Conclusion}

The usage of the convergent parallel design revealed nuanced trajectories of interactions of the buffered states within the buffer system. The study affirms that the buffer system is a dynamic political space for the buffered states to compete in; it includes dynamic interplay between rhetorical and material forces, as inferred through the analyses. While the dynamics of the buffer system have been discussed in detail in the chapter, it has to be noted that there are consistent trajectories in the buffer system as well. While the number of rhetorical statements as well as the negative and positive affirmations change, the themes of "cooperation," "development," and "assistance" remain consistent in both India and China's interactions with Nepal. As such, the rhetoric base is strongly tied to development and aid, with aims to foster positive perception within Nepal. ${ }^{313}$ Nevertheless, the combined quantitative and qualitative analyses showcase sub-systemic interactions, with noticeable changes in rhetoric and material commitments. As such, although the rhetorical base is strongly positive, there are fluctuations that occur pre, during and postcritical junctures. The material changes do not exhibit consistency but coupled with qualitative data, different trajectories of engagement emerge for Indo-Nepali and SinoNepali relations.

\footnotetext{
${ }^{313}$ For details, refer to Table 3 on page number 157.
} 


\section{CHAPTER VII: CONCLUSION}

The dissertation sought to contextualize the buffer state concept in contemporary International Relations and decipher its importance in international politics. It linked the buffer system concept to that of sub-systemic/regional dynamics of politics, with the notion that smaller states are important in the strategies of larger powers. Additionally, the dissertation sought to utilize a novel research approach to add to the scant literature on buffer states. Buffer states, traditionally seen as geographic discontinuities, are indeed spaces of dynamic political interactions. As showcased by the analyses conducted in this dissertation, the buffer states are not simply states that exist in the periphery; they are important political spaces wherein larger powers showcase dynamic interactions based on increased or decreased sub-systemic rivalry.

\section{Revisiting the Research Question and Hypotheses}

The research question, which asked why and how buffer states are relevant in subsystemic rivalries, sought to address their role that is not exclusive to their geographic function. The main rationale for raising the question was the fact that buffer states are no longer tied exclusively to their geographic disposition; apart from their geographic

importance, buffer states are important for their role as a dynamic political space for interactions for the buffered states. The convergent parallel analysis showcased that buffer states do exhibit roles that are important for contemporary International Relations.

Buffer states maintain relevance in the form of a political space for dynamic material and rhetorical interactions between buffered states. The case study of the India- 
Nepal-China buffer system showcased these trajectories, as India and China utilized divergent means of engagement with Nepal during and after critical historical years for the buffer state. In essence, buffer states are relevant in sub-systemic rivalries given their geographic disposition between larger powers; but, their utility extend beyond just its geographic importance. Buffered states maintain the relevance of the buffer state through dynamic material and rhetorical interactions, during and after critical junctures. The discussion of the hypotheses will add nuances to how China and India interact with Nepal.

H1: If sub-systemic rivalries among Middle or Great powers envelop a small, buffer state, then this rivalry will recover the buffer state's political relevance beyond a simple geographical discontinuity among rivalrous powers.

The overarching hypothesis is based on the premise that when sub-systemic rivalries between middle or great powers intensify, then the buffer state's political relevance increases as well, and not just tied to its geographic function as a spatial discontinuity. Thus, sub-systemic rivalries are assumed to intensify at the critical junctures, given their implications for changes in policy during such periods. The results for the measures of political relevance for the buffer state showcase mixed results. In essence, the hypothesis can be largely accepted in the case of the India-Nepal-China buffer system as quantitative as well as qualitative measures of relevance show increases/decreases (increased relevance) during critical junctures. The political relevance for Nepal is heightened for India during the critical juncture, as it increases both material and rhetorical engagements. On the other hand, China's material engagement decreases, while rhetorical 
engagement increases. In essence, relevance of the buffer state cannot just be captured by increases; decreases also showcase the dynamic nature of sub-systemic interactions and are essential in the overall understanding of the research puzzle. The discussions on the individual hypotheses will further shed light on these dynamics.

H2: At critical junctures, trade figures will intensify between Nepal-India and Nepal-China due to increase in sub-systemic rivalry.

During periods of intensified sub-systemic rivalries i.e. during critical junctures, India-Nepal trade figures increase. On the contrary, trade figures between China-Nepal decreases during the same time. This hypothesis is accepted as both India-Nepal and ChinaNepal interactions in terms of intensifications, albeit India expresses it through increase and China through decrease in trade.

H3: At critical junctures, FDI figures will intensify between Nepal-India and Nepal-China due to increase in sub-systemic rivalry.

For FDI from India to Nepal, critical juncture periods witness extensive increases, while FDI from China into Nepal decreases during the same period. As such, the hypothesis is accepted albeit the direction of intensification of relations are opposite, just as it is the case for the hypothesis on trade. 
H4: At critical junctures, foreign aid figures will intensify between Nepal-India and NepalChina due to increase in sub-systemic rivalry.

Hypothesis 4 is accepted as well. Foreign aid from India increase extensively during this period but decreases for China.

H5: At critical junctures, rhetorical engagement will intensify between Nepal-India and Nepal-China due to increase in sub-systemic rivalry.

This hypothesis is accepted as rhetorical engagement emanating from India and China regarding Nepal increases during this period. Interestingly, positive affirmation from India decreases but that from China increases as well. Also, India's emphasis on "visit" drops during the critical junctures, while China's emphasis on "friendly" is unique in the assessments carried out in this dissertation.

All the hypotheses are accepted as both material and rhetorical engagements intensify during critical junctures, showcasing increased sub-systemic interest in the buffer state i.e. increased relevance of the buffer state in the buffer system. Interestingly, the intensification for both rhetoric and material in India's case has been an increase across all variables. As for China, the intensification is in the form of decrease, which also occurs across all of the variables. However, the application of dictionaries in qualitative analysis part of the study shows that despite decreases in overall rhetorical engagement from China during critical junctures, there is an overall increase in positive affirmation; at the same 
time, there is a decrease in positive affirmation and increase in negative affirmation from India.

Thus, the critical junctures, which signify changes in sub-systemic rivalries, witness the intensification of the role of India and China, which are larger powers in the buffer system. As such, buffer states are not simply geographic barriers; they are political spaces that showcase intense material and rhetorical interactions. The critical junctures support the notion that buffer states are not simply geographic discontinuities; the dynamic changes in trade, FDI, foreign aid, and rhetorical statements all showcase the strategic importance of Nepal for both India and China. Thus, the buffer state Nepal maintains relevance in sub-systemic rivalries

While the assessment of the critical junctures showcase intensification, the trends for sub-systemic interactions are further explained by analyzing the post-critical juncture periods. India uses material and rhetorical means to influence Nepal during critical junctures while not shying away from using rhetoric with negative connotation. India then de-escalates through overall decrease in material engagement and increase in positive connotation. China decrease material engagement but uses rhetorical engagement with increase in positive connotation during critical junctures. It de-escalates rhetorical engagement but increases foreign aid after the critical juncture. In essence, India's approach to critical junctures in the sub-system includes action from the get-go, while China only increases rhetoric, while preferring to use foreign aid as a means of extending its influence after the critical junctures. Additionally, both China and India showcase increase in "visits" after the critical junctures, which also signal maintained relevance of the buffer state Nepal, be it for maintenance of preponderance or extension of influence. 
The results of this study show that the buffer state in this case is more than just a geographic break between larger powers. It is a platform wherein the buffered states interact, materially and rhetorically, in distinct patterns. The buffered states interact with the buffer in differing trajectories; engagement and disengagement during specific years of critical events are strategies that support the notion of strategic competition between the larger powers. For example, India increases while China decreases material engagement, China being acutely aware of India's preponderant interests in Nepal. This strategic competition is bolstered by the fact that the non-parametric correlations showcase competitive increases in FDI and foreign aid from India and China, in relation to each other. Furthermore, these variables are characterized by increase over time. Also, the rivalries of sub-systemic powers go beyond critical junctures; the post-critical juncture period showcases its own trajectories, which are different from those during the critical junctures. Thus, buffer states maintain relevance not just during critical junctures but after such events as well.

\section{Major Insights from the Study}

First, the study adds to the limited literature on buffer states. It applies the convergent parallel design to analyze sub-systemic interactions in the buffer state. The results showcase the dynamic nature of the buffer system, away from strictly geographic conceptions. Rhetoric and monetary tools are shown to be used strategically in times of crisis and change in the buffer state. This opens up avenues for other buffer states to be studied using this framework in order to analyze how sub-systemic rivalries operate and how they impact the buffer states. 
Second, it showcases that buffered states have degrees of influence over the buffer state. In this case, India's influence is preponderant in Nepal and how it behaves during critical years is very different from how China interacts with Nepal in those same years. For example, India uses negative affirmation more confidently while ramping up material support during critical junctures; China focuses on rhetoric, increasing its engagement with statements that emphasize "friendship." As such, India seeks to maintain its influence, while China is cognizant of India's preponderance but also wants to headway in its relations with Nepal. Buffered states may behave differently based on their standing within the buffer state.

Third, the combined usage of quantitative and qualitative data allowed for a more complete understanding of sub-systemic interactions in the buffer state. Using FDI, foreign aid, and trade data along with rhetorical statements allowed for a more nuanced understanding of how the buffered states interact with the buffer state. For example, despite decrease in material commitment during critical junctures, China increased its rhetorical engagement during the same period. Thus, it shows that despite decrease in material engagement, China's rhetorical engagement increases as it does not seek to completely disengage with Nepal during critical junctures.

Fourth, small states still maintain relevance for larger powers. As is the case for Nepal as a state sandwiched between India and China, the buffer state in this case is shown to have been a political space for both material and rhetorical engagements. Thus, small states, particularly buffer states should garner more attention as they aid in deciphering the patterns of behavior of larger states. 
Fifth, this dissertation also adds another dimension to the study of rivalry. While dyadic interactions are usually the fallback for rivalry studies, emphasis on externalization of such rivalries in smaller states adds an important dimension. In essence, rivalry studies could benefit from utilizing small states as case studies to decipher how rivalries externalize in other forms of political spaces.

Sixth, the framework connects geopolitics with regional/sub-systemic approaches to security studies. As such, it bridges the gap between the two sub-disciplines in order to garner a coherent analytical picture of the buffer system.

Overall, this dissertation affords a novel framework to analyze the role of other buffer states in the international system. It reinforces the idea that buffer states are dynamic political spaces wherein larger powers pursue their respective strategic interests competitively. Concurrently, it adds to the study of regional security dynamics by according importance to the interactions of regional powers in their respective regional contexts. 


\section{LIST OF REFERENCES}

Adhikari, Krishna Kant. "The Status, Powers and Functions of Rajas and Rajautas during the Nineteenth Century Nepal in the Light of Contemporary Documents." Contributions to Nepalese Studies VIII, no. 1 (1980).

Adhikari, Monalisa. "Between the Dragon and the Elephant: Nepal's Neutrality Conundrum.” Indian Journal of Asian Affairs 25, no. 1/2 (2012): 83-97.

Agence France-Presse and Staff. "Nepal Donors Pledge \$3bn for Rebuilding in Aftermath of Earthquakes." The Guardian, 2015. https://www.theguardian.com/global-development/2015/jun/25/nepalearthquakes-3bn-aid-pledge-international-donors-kathmandu.

Al-Rodhan, Nayef R.F. Neo-statecraft and Meta-geopolitics: Reconciliation of Power, Interests, and Justice in the 21st Century. Zurich, Switzerland: Lit Verlag, 2009.

Amstrup, Niels. 1976. "The Perennial Problem of Small States: A Survey of Research Efforts." Cooperation and Conflict 11, no. 2 (1976): 163-182.

Anderson, Ashlyn, and Alyssa Ayres. "Disaster Relief: China and India Come Together." Council on Foreign Relations, 2015. https://www.cfr.org/expert-brief/disasterrelief-china-and-india-come-together.

Aneja, Atul. "China Stresses on Ties with Nepal, India.” The Hindu, 2018. http://www.thehindu.com/news/international/china-stresses-on-ties-with-nepalindia/article23589865.ece.

Apodaca, Clair. "Foreign Aid as Foreign Policy Tool." Oxford Research Encyclopedia of Politics. Oxford University Press, 2017.

Ayson, Robert, and Brendan Taylor. "Carrying China's Torch.” Survival 50, no. 4 (2008): 5-10.

Bailes, Alyson J K, Bradley A Thayer, and Baldur Thorhallsson. "Alliance Theory and Alliance 'Shelter': The Complexities of Small State Alliance Behaviour Small State Alliance Behaviour." Third World Thematics: A TWQ Journal 1, no. 1 (2017): 9-26.

Baral, Lok Raj. "Nepal in 2001: The Strained Monarchy.” Asian Survey 42, no. 1 (2002): 198-203. 
Basu, Narayani. “Nepal-China-India: Three's a Crowd?” The Diplomat, 2017. https://thediplomat.com/2017/08/nepal-china-india-threes-a-crowd/.

Bayly, Martin J. “Imperial Ontological (In)security: 'Buffer States', International Relations and the Case of Anglo-Afghan Relations, 1808-1878." European Journal of International Relations 21, no. 4 (2015): 816-40.

"The Belt and Road Initiative - A Road Map to the Future." The Hong Kong Trade Development Council, 2017. https://beltandroad.hktdc.com/en/belt-and-roadbasics.

Bennett, Andrew. "Case Study Methods: Design, Use, and Comparative Advantages." In Cases, Numbers, Models: International Relations Research Methods, edited by Detlef F. Sprinz and Yael Wolinsky, 27-64. Ann Arbor, MI: Michigan University Press, 2004.

Bennett, D Scott. "Security, Bargaining, and the End of Interstate Rivalry." International Studies Quarterly 40, no. 2 (1996): 157-83.

Bhasin, Avtar Singh (ed.). Nepal-India, Nepal-China Relations Volume 1. Delhi, India: Geetika Publishers, 2005.

Bhattarai, Madan Kumar. Diplomatic History of Nepal (1901-1929): A Critical Appraisal of Nepal-British-Indian Relations. New Delhi, India: Ashoka Printers, 1990). Accessed at the Ministry of Archaeology, Kathmandu, Nepal on $10^{\text {th }}$ June, 2016.

Bhogal, Preety. "The Politics of India's Foreign Aid to South Asia." Global Policy, November 2016. http://www.globalpolicyjournal.com/blog/07/11/2016/politicsindia's-foreign-aid-south-asia.

Biswas, Soutik. "Nepal Earthquake: How India and China Vie for Influence." BBC News, 2015. http://www.bbc.com/news/world-asia-india-32492273.

Biswas, Soutik. "Why Is Indian Media Facing a Backlash in Nepal?” BBC News, 2015. http://www.bbc.com/news/world-asia-india-32579561.

Budhathoki, Shyam Sundar, and Hellen Gelband. "Manmade Earthquake: The Hidden Health Effects of a Blockade-Induced Fuel Crisis in Nepal." BMJ Global Health 1, no. 2 (2016).

Butterfield, Herbert. "The Balance of Power." In Diplomatic Investigations, Essays in the Theory of International Politics, edited by Herbert Butterfield and Martin Wright. Cambridge, MA: Harvard University Press, 1968. 
Buzan, Barry and Ole Wæver, Regions and Powers: The Structure of International Security. Cambridge, UK: Cambridge University Press, 2003.

Buzan, Barry. "The South Asian Security Complex in a Decentring World Order: Reconsidering Regions and Powers Ten Years On." International Studies Quarterly 48, no.1 (2011): 1-19.

Cantori, Louis J., and Steven L. Spiegel. "International Regions: A Comparative Approach to Five Subordinate Systems." International Studies Quarterly 13, no. 4 (1969): 361-80.

Chalmers, Rhoderick. “Toward a New Nepal?" Current History: A Journal of Contemporary World Affairs 106, no. 699 (2007): 161-67.

Chand, Bibek. "Disaster Relief as a Political Tool: Analysing Indian and Chinese Responses after the Nepal Earthquakes." Strategic Analysis 41, no. 6 (2017): 53545.

Chand, Bibek and Lukas Danner. "Implications of the Dragon's Rise for South Asia: Assessing China's Nepal Policy.” Strategic Analysis 40, no.1: 26-40.

Chay, John and Thomas E. Ross. Buffer States in International Politics. Boulder, CO: Westview Press, 1986.

Chay, John and Thomas E. Ross. 1986. "Introduction." In Buffer States in World Politics, edited by John Chay and Thomas E. Ross, 1-7. Boulder, CO: Westview Press.

Chay, John and Thomas E. Ross. 1986. "Preface.” In Buffer States in World Politics, edited by John Chay and Thomas E. Ross, xiii-xiv. Boulder, CO: Westview Press.

"China Calls Dalai Lama a 'Separatist', Says he Fled After Failed Armed Rebellion." The Hindustan Times, April 8, 2017.

https://www.hindustantimes.com/world-news/china-calls-dalai-lama-a-separatistsays-he-fled-after-failed-armed-rebellion/storyzDQ7oFcG4D7UFNdblP3DlK.html.

Chowdhury, Debasish Roy. "China Scores as Nepal Plays Hardball with India Over Border 'Blockade."” South China Morning Post, 2015. http://www.scmp.com/news/china/diplomacy-defence/article/1898210/chinascores-nepal-plays-hardball-india-over-border.

The CNN Wire Staff. "Timeline of Tibetan Protests in China." CNN, 2012. http://www.cnn.com/2012/01/31/world/asia/tibet-protests-timeline/index.html. 
Collier, David, and Gerardo L. Munck. "Symposium on Critical Junctures and Historical Legacies." Qualitative and Multi-Method Research Section of the American Political Science Association 15, no. 1 (2017): 1-47.

Comfort, Louise K. "Disaster: Agent of Diplomacy or Change in International Affairs?" Cambridge Review of International Affairs 14., no.1 (2000): 277-294.

Cottle, Drew, and Angela Keys. "The Maoist Conflict in Nepal: A Himalayan Perdition?" Australian Journal of International Affairs 61, no. 2 (2007): 168-74.

Creswell, John W. and Vicki L. Plano Clark. Designing and Conducting Mixed Methods Research. Thousand Oaks, CA: SAGE Publications Inc., 2011.

Crossette, Barbara. "Nepal: The Politics of Failure." World Policy Journal 22, no. 4 (2005): 69-76.

Dabhade, Manish and Harsh V. Pant. "Coping with the Challenges to Sovereignty: SinoIndian Rivalry and Nepal's Foreign Policy." Contemporary South Asia 13, no.2 (2004): 157-169.

Davies, John, Nigel Jenkins, and Menna Baines. "The March.” The Welsh Academy Encyclopedia of Wales. Literature Wales, 2008.

Davis, Paul K., Eric V. Larson, Zachary Haldeman, Mustafa Oguz, and Yashodhara Rana. Understanding and Influencing Public Support for Insurgency and Terrorism. RAND Corporation, 2012.

Demick, Barbara. "Tibet's Road Ahead: Tibetans Lose a Haven in Nepal Under Chinese Pressure." Los Angeles Times, 2015. http://www.latimes.com/world/asia/la-fg-tibet-nepal-20150806-story.html.

Destradi, Sandra. "Regional Powers and Their Strategies: Empire, Hegemony, and Leadership" 36, no. 4 (2010): 903-30.

Destradi, Sandra."India as a Democracy Promoter? New Delhi's Involvement in Nepal's Return to Democracy." Democratization 19, no.2 (2012): 286-311.

"Development Cooperation Report." Ministry of Finance, Government of Nepal. 2015/16.

Dhanlaxmi, Ravuri. British Attitude to Nepal's Relations with Tibet and China (18141914). Delhi, India: Bahri Publications Private Limited, 1981. Accessed at the British Library, London on 12th August, 2016. 
Diehl, Paul F. "Contiguity and Military Escalation in Major Power Rivalries, 18161980.” The Journal of Politics 47, no.4 (1985): 1203-1211.

Dixit, Ashutosh M. “China's Belt and Road Comes to Nepal.” The Diplomat, 2017. https://thediplomat.com/2017/07/chinas-belt-and-road-comes-to-nepal/.

Donnelly, Paul and John Hogan. "Understanding Policy Change Using a Critical Junctures Theory in Comparative Context: The Case of Ireland and Sweden." Policy Studies Journal 40, no.2(2012): 324-350.

Doshi, Vidhi. "Nepal votes Thursday. China and India are Watching Closely." The Washington Post, 2017. https://www.washingtonpost.com/world/asia_pacific/nepal-votes-thursday-willchina-or-india-come-out-the-winner/2017/12/05/41473934-d550-11e7-9ad9ca0619edfa05_story.html?utm_term $=.4478 \mathrm{f} 7 \mathrm{f} 24 \mathrm{ecc}$

Dreher, Axel, Andreas Fuchs, Bradley Parks, Austin M. Strange, and Michael J. Tierney. "Aid, China, and Growth: Evidence from a New Global Development Finance Dataset.” AidData. Working Paper \#46, 2017.

Embassy of India in Kathmandu, Nepal, http://www.indianembassy.org.np/.

Fazal, Tanisha M. State Death: The Politics and Geography of Conquest, Occupation, and Annexation. Princeton, NJ: Princeton University Press, 2007.

Fromkin, David. “The Great Game in Asia.” Foreign Affairs 58, no. 4 (1980): 936-51.

"Full Text: Action Plan on the Belt and Road Initiative." The State Council, The People's Republic of China, 2015. http://english.gov.cn/archive/publications/2015/03/30/content_281475080249035. $\underline{\mathrm{htm}}$.

Ganguly, Sumit and Brian Shoup. "Nepal Between Dictatorship and Anarchy." Journal of Democracy 16, no.4 (2005): 129-143.

Garver, John W. "The Diplomacy of a Rising China in South Asia," Orbis 56, no.3 (2012): 391-411.

Garver, John. "The Security Dilemma in Sino-Indian Relations," India Review 1, no.4 (2002): 1-38.

Gear, Mary. 1941. "Role of Buffer States in International Relations." The Journal of Geography XL (3): 81-89. 
Gibert, Marie V, and Virginie Grzelczyk. "Non-Western Small States: Activists or Survivors?" Third World Thematics: A TWQ Journal 1, no. 1 (2017): 1-8.

Gigleux, Victor. "Explaining the Diversity of Small States' Foreign Policies through Role Theory." Third World Thematics: A TWQ Journal 1, no. 1 (2017): 27-45.

Glaser, Charles. "Will China's Rise Lead to War? Why Realism Does Not Mean Pessimism." Foreign Affairs 90, no. 2 (2011): 80-91.

Google Maps. “Asia.” 2017. Accessed August 28, 2017. https://www.google.com/maps/place/Asia/@30.136028,74.6637773,4.25z/data=! 4m5!3m4!1s0x3663f18a24cbe857:0xa9416bfcd3a0f459!8m2!3d34.047863!4d10 $\underline{0.6196553}$

Gowen, Annie. "U.S. Military wants India to Counterbalance China's Rise as a Sea Power," The Washington Post, June 5, 2016. Accessed November 2016 at https://www.washingtonpost.com/world/asia_pacific/us-military-wants-india-tocounterbalance-chinas-rise-as-a-sea-power/2016/06/05/5caf6f24-280a-11e6-8329-

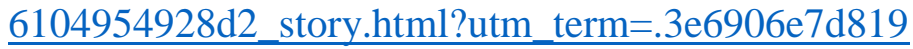

Gray, Colin S. War, Peace, and International Relations: An Introduction to Strategic History. New York, NY: Routledge, 2012.

Greenfeld, Karl Taro. "The Death of Vishnu.” Time, 2001. http://content.time.com/time/magazine/article/0,9171,128973,00.html.

Grøn, Caroline Howard, and Anders Wivel. "Maximizing Influence in the European Union after the Lisbon Treaty: From Small State Policy to Smart State Strategy." Journal of European Integration 33, no. 5 (2011): 523-39.

Hachhethu, Krishna. "Legitimacy Crisis of Nepali Monarchy." Economic and Political Weekly 42, no. 20 (2007): 1828-33.

Handel, Michael I. Weak States in the International System. New York, NY: Frank Cass, 1990.

Heck, Douglas. "Nepal in 1980: The Year of the Referendum." Asian Survey 21, no.2 (1981): 181-187.

Heuer, Marleen. "China Increases Influence over Tibetan Refugees in Nepal." Deutsche Welle, 2016. http://www.dw.com/en/china-increases-influence-over-tibetanrefugees-in-nepal/a-19511365. 
Hogan, John, and David Doyle. "The Importance of Ideas: An A Priori Critical Juncture Framework." Canadian Journal of Political Science 40, no. 4 (2007): 883-910.

Hutt, Michael. "Monarchy, Maoism and Democracy in Nepal." Conflict, Security \& Development 1, no. 2 (2001): 93-101.

Hutt, Michael. "A Nepalese Triangle: Monarchy, Maoists and Political Parties." Asian Affairs 38, no. 1 (2007): 12-22.

Hutt, Michael. "Singing the New Nepal." Nations and Nationalism 18, no. 2 (2012): 30625.

Ikenberry, J. John. "The Rise of China and the Future of the West: Can the Liberal System Survive?” Foreign Affairs 87, no.1 (2008): 23-37.

“India's 'Operation Maitri’ in Earthquake-Hit Nepal Ends.” NDTV, 2015. https://www.ndtv.com/india-news/indias-operation-maitri-in-earthquake-hitnepal-ends-768795.

Ingalls, Gerald L. "Buffer States: Outlining and Expanding Existing Theory." In Buffer States in World Politics, edited by John Chay and Thomas E. Ross, 231-240. Boulder, CO: Westview Press, 1986.

Iyengar, Rishi. "Millions of Children Are at Risk Because of the Nepal Blockade, UNICEF Warns." Time, 2015. http://time.com/4130341/nepal-blockade-vaccineshortage-children-unicef/.

Jawaharlal Nehru's Speeches: Volume Two (August 1949-February 1953). New Delhi, India: Publications Division: Ministry of Information and Broadcasting, Government of India, 1963.

Jha, Hari Bansh. "Nepal's New Tryst with Democracy and the 'India Factor'." Centre for Land Warfare Studies Journal, Winter 2014.

Jha, Prashant. "Nepal's Contested Constitution Deepens Crisis at Home and With India." World Politics Review, 2015. https://www.worldpoliticsreview.com/articles/17126/nepal-s-contestedconstitution-deepens-crisis-at-home-and-with-india.

Johnston, Alastair Iain. "Is China a Status Quo Power?" International Security 27, no. 4 (2003): 5-56.

Jones, Lee, and Yizheng Zou. "Rethinking the Role of State-Owned Enterprises in China’s Rise.” New Political Economy 22, no. 6 (2017): 743-60. 
Kant, Rama. "Nepal's Foreign Policy and China." India Quarterly 27, no. 3 (1971): 20312.

Kassimeris, Christos. “The Foreign Policy of Small Powers.” International Politics 46, no. 1 (2009): 84-101.

Kelly, Philip. "Buffer Systems of Middle America." In Buffer States in World Politics, edited by John Chay and Thomas E. Ross, 67-84, Boulder, CO: Westview Press, 1986.

Kelly, Philip. Checkerboards and Shatterbelts: The Geopolitics of South America. Austin, TX: University of Texas Press, 1997.

Keohane, Robert O. “Lilliputians' Dilemmas: Small States in International Politics." International Organization 23, no.2(1969): 291-310.

Kreps, Sarah E., and Gustavo A. Flores-Macias. "No Strings Attached? Evaluating China's Trade Relations Abroad." The Diplomat, 2013. https://thediplomat.com/2013/05/no-strings-attached-evaluating-chinas-traderelations-abroad/.

Krishnan, S Venkata, and Gayatri Dhal. 2014. "India-African Union: An Asymmetric Quasi-Interregional Sub-System.” Procedia - Social and Behavioral Sciences 157: 266-76.

Lawoti, Mahendra, and Anup Kumar Pahari. The Maoist Insurgency in Nepal: Revolution in the Twenty-First Century. New York, NY: Routledge, 2009.

Levi, Werner. "Bhutan and Sikkim: Two Buffer States." The World Today 15, no. 12 (1959): 492-500.

Long, Tom. "Small States, Great Power? Gaining Influence Through Intrinsic, Derivative, and Collective Power." International Studies Review 19, no. October (2017): 185-205.

Maass, Matthias. Small States in World Politics: The Story of Small State Survival, 16482016. 1st ed. Manchester: Manchester University Press, 2017.

Mackinder, Halford J. “The Geographical Pivot of History.” The Geographical Journal 23, no.4 (1904): 421-437.

Mage, John. "The Nepali Revolution and International Relations." Economic and Political Weekly 42, no. 20 (2007): 1834-39. 
Maila, Joseph. "Buffer States: The Issue of Sovereignty." In Buffer States in World Politics, edited by John Chay and Thomas E. Ross, 29-40, Boulder, CO: Westview Press, 1986.

Mansingh, Surjit. "India-China Relations in the Post-Cold War Era." Asian Survey 34, no.3 (1994): 285-300.

"Marcher Lords." The Hutchinson Unabridged Encyclopedia with Atlas and Weather Guide. Helicon, 2016.

Marshall, Catherine and Gretchen B. Rossman. Designing Qualitative Research. Thousand Oaks, CA: SAGE Publications Inc., 1999.

Mathisen, Trygve. The Functions of Small States in the Strategies of the Great Powers. Oslo, Norway: Universitetsforlaget, 1972.

Mearsheimer, John J. “China’s Unpeaceful Rise.” Current History 105, no.690 (2006): 160-162.

Media Center. Ministry of External Affairs, Government of India. http://mea.gov.in/index.htm.

Meltzer, Joshua P. “China's One Belt One Road Initiative: A View from the United States.” Brookings Institute, 2017. https://www.brookings.edu/research/chinasone-belt-one-road-initiative-a-view-from-the-united-states/.

Ministry of Commerce of People's Republic of China, National Bureau of Statistics of People's Republic of China, and State Administration of Foreign Exchange. 2011 年度 中国对外直接投资 统计公报 2011 Statistical Bulletin of China's Outward Foreign Direct Investment. China Statistics Press, 2012. http://images.mofcom.gov.cn/hzs/201309/20130923082710756.pdf.

Mishra, Rabindra. "India's Role in Nepal's Maoist Insurgency." Asian Survey 44, no. 5 (2004): 627-46.

Mitchell, Sarah McLaughlin and Cameron G. Thies. 2011. "Issue Rivalries." Conflict Management and Peace Science 28, np.3 (2011): 230-260.

Mitra, Subrata K. \& Srikanth Thaliyakkattil. "Bhutan and Sino-Indian Rivalry.” Asian Survey 58, no.2 (2018): 240-260.

Morse, Janice M., \& Linda Niehaus. Mixed Methods Design: Principles and Procedures. Walnut Creek, CA: Left Coast Press, 2009. 
Mouritzen, Hans and Anders Wivel. "Introduction." In The Geopolitics of Euro-Atlantic Integration, edited by Hans Mouritzen and Anders Wivel, 1-12. Oxon, OC: Routledge, 2005.

Muni, SD. "'Royal Coup' in Nepal: Why and What Now?” Economic and Political Weekly 40, no. 7 (2005): 617-18.

Murthy, Padmaja. "Understanding Nepal Maoists' Demands: Revisiting Events of 1990." Strategic Analysis 21, no. 1 (2003): 41-55.

Nachmias, David, and Chava Nachmias. "Content Analysis." In Research Methods in the Social Sciences, 132-39. UK: Edward Arnold, 1976.

Nel, Philip. "Redistribution and Recognition: What Emerging Regional Powers Want." Review of International Studies 36, no. 4 (2010): 951-74.

"Nepal Earthquake - Fact Sheet \#1.” USAID, 2015. https://www.usaid.gov/nepalearthquake/fy15/fs01.

"Nepal Earthquake: India and China Pledge Millions in Aid." BBC News, 2015. http://www.bbc.com/news/world-asia-33266422.

Nepal - Independent Status of, Correspondence from Nepali Prime Minister Chandra Shamsher Rana to Lieutenant-Colonel J. Manners Smith, Resident in Nepal. April 1 1916. File No. 2/1960, British Embassy F.O. 766/2. The National Archives, Kew Gardens, London, UK.

Nepal-India Chamber of Commerce \& Industry, "Top 5 Countries of FDI Commitments in Nepal - Fiscal Year and Country Wise," 2017. http://www.nicci.org/pdf/Top\%205\%20countires\%20of\%20FDI\%20Commitment s\%20in\%20NepalFYwise $\% 20$ and $\% 20$ countrywise $\% 20$ for $\% 205 \% 20$ years $\% 20+9$ months $\% 20$ \%202011-12\%20to\%202016-17\%20(9\%20months).pdf.

"Nepal to Request China to Expand Araniko Highway." E-Kantipur, 2015. http://kathmandupost.ekantipur.com/news/2015-11-29/nepal-to-request-china-toexpand-araniko-highway.html.

"Nepal Plans to Build Three More Fuel Depots." The Himalayan Times, 2015. https://thehimalayantimes.com/business/nepal-plans-to-build-three-more-fueldepots/.

“Nepal Shuts Down Tibetan Offices.” BBC News, 2005. http://news.bbc.co.uk/2/hi/south_asia/4214933.stm. 
"Nepal Trade at a Glance: Most Recent Values." World Integrated Trade Solution, 2018. https://wits.worldbank.org/CountrySnapshot/en/NPL/textview

"Net ODA." OECD Data, 2017. https://data.oecd.org/oda/net-oda.htm.

Neuendorf, Kimberly A. The Content Analysis Guidebook. 2nd ed. Thousand Oaks, CA: SAGE Publications, Inc., 2017.

"Notes on Demands for Grants (2000/01, 2001/02, 2002/03, 2003/04, 2004/05, 2005/06, 2006/07, 2007/08, 2008/09, 2009/10, 2010/11, 2011/12, 2012/13, 2013/14, 2014/15, 2015/16, 2016/17, and 2017/18)." Ministry of Finance, Government of India. http://indiabudget.nic.in.

Obe, Mitsuru and Niharika Mandhana. "India and Japan Pursue Closer Ties to Counter China." The Wall Street Journal, September 1, 2014. https://www.wsj.com/articles/indias-prime-minister-narendra-modi-wants-closerties-with-japan-to-counter-china-1409555754

Okolo, Abutu Lawrence. "China's Foreign Policy Shift in Africa: From Non-Interference to Preponderance." International Journal of African Renaissance Studies 10, no. 2 (2015): 32-47.

Oyvind, Osterud. "Regional Great Powers.” In Regional Great Powers in International Politics, edited by Iver B. Neumann, 1-15. New York, NY: St. Martin's Press Inc., 1992.

Panda, Ankit. "In Nepal Earthquake's Aftermath, India and China Respond.” The Diplomat, 2015. https://thediplomat.com/2015/04/in-earthquakes-aftermath-indiaand-china-respond/.

Pape, Robert A. "Soft Balancing Against the United States." International Security 30, no. 1 (2005): 7-45.

Paramanand. “Nepal's China Policy.” China Report 16, no. 6 (1980): 9-17.

Parashari, Sachin. "China Pips India in Aid to Nepal; Delhi Out of Top Five Donors' List." The Times of India, May 10, 2016. https://timesofindia.indiatimes.com/india/China-pips-India-in-aid-to-Nepal-Delhiout-of-top-five-donors-list/articleshow/52180744.cms.

Partem, Michael Greenfield. "The Buffer System in International Relations." The Journal of Conflict Resolution 27, no.1 (1983): 3-26.

Paterson, William E. "Small States in International Politics." Cooperation and Conflict 4, no.1 (1969): 119-123. 
Paterson, Barbara L. "Within-Case Analysis." Encyclopedia of Case Study Research, 2010.

Patnaik, Sivananda. "Sri Lanka and the South Asian Sub-System: A Study of Submarco International Politics." India Quarterly 36, no. 2 (1980): 137-58.

Paul, T.V. International Relations Theory and Regional Transformation. Cambridge, UK: Cambridge University Press, 2012.

Perlez, Jane, and Yufan Huang. "Behind China's \$1 Trillion Plan to Shake Up the Economic Order." The New York Times, May 13, 2017.

https://www.nytimes.com/2017/05/13/business/china-railway-one-belt-one-road1-trillion-plan.html.

Pethiyagoda, Kadira. "Order from Chaos: Why Small States matter in International Politics: The Case of Sri Lanka." The Brookings Institution. Last modified September 3, 2015. https://www.brookings.edu/blog/order-fromchaos/2015/09/03/why-small-states-matter-in-international-politics-the-case-ofsri-lanka/.

Poast, Paul. "Can Issue Linkage Improve Treaty Credibility? Buffer State Alliances as a “"Hard Case."” Journal of Conflict Resolution 57, no. 5 (2012): 739-64.

"Presidents Bush, Chirac Announce Recent Increases in Aid to Conference on Financing Development." United Nations Press Release, 2002. http://www.un.org/press/en/2002/dev2388.doc.htm.

Prys, Miriam. Redefining Regional Power in International Relations: Indian and South African Perspectives. London, UK: Routledge, 2012.

Prys, Miriam. "India and South Asia in the World: On the Embeddedness of Regions in the International System and Its Consequences for Regional Powers." International Relations of the Asia-Pacific 13, no. 2 (2013): 267-99.

Rana, Madhukar S J B. "China Meets India in Nepal: A Historical and Future Perspective." Indian Journal of Asian Affairs 26, no. 1/2 (2013): 59-73.

Reddy, Vidya Sagar. "Reinforcing China's Malaccas Dilemma." Center for International Maritime Security, 2016. http://cimsec.org/reinforcing-chinas-malaccadilemma/28117.

Reeves, Jeffrey. 2012. "China's Self-Defeating Tactics in Nepal." Contemporary South Asia 20(4): 525-31.

Reserve Bank of India. "Publications." https://www.rbi.org.in/Scripts/Publications.aspx. 
Rezun, Miron. "The Great Game Revisited.” International Journal 41, no. 2 (1986): 324-41.

Ross, Thomas E. 1986. "Buffer States: A Geographer's Perspective." In Buffer States in World Politics, edited by John Chay and Thomas E. Ross, 11-28. Boulder, CO: Westview Press.

Rothstein, Robert. Alliances and Small Powers. New York, NY: Columbia University Press, 1968.

Runde, Daniel. "Foreign Aid Is about U.S. Interests." Foreign Policy, 2017. http://foreignpolicy.com/2017/06/26/foreign-aid-is-about-u-s-interests-marshallplan/.

Sangraula, Bikash. "Nepal Accuses India of an Economic Blockade as Border Trade Freezes Up." Christian Science Monitor, 2015. https://www.csmonitor.com/World/Asia-South-Central/2015/0928/Nepal-accusesIndia-of-an-economic-blockade-as-border-trade-freezes-up.

Sapkota, Rupak. 'Nepal's Role in China's Belt and Road Initiative Highlights Balancing Act between Beijing and Delhi." South China Morning Post, n.d. http://www.scmp.com/news/china/diplomacy-defence/article/2110474/nepalsrole-chinas-belt-and-road-initiative-highlights.

Schake, Kori and Anja Manuel. "How to Manage a Rising Power - or Two." The Atlantic, May 24, 2016. Accessed October 2016 at https://www.theatlantic.com/international/archive/2016/05/china-india-risingpowers/484106/.

Semple, Ellen Churchill. 1911. Influences of Geographic Environment on the Basis of Ratzel's System of Anthropo-Geography. New York, NY: Henry Holt and Company.

Senese, Paul D. "Territory, Contiguity, and International Conflict: Assessing a New Joint Explanation.” American Journal of Political Science 49, no.4 (2005): 769-779.

Shakya, Tsering, and Ashok Gurung. "Was Nepal a Soft Power Victory for China?" Foreign Policy, 2015. http://foreignpolicy.com/2015/05/01/nepal-chinaearthquake-aid-taiwan-power/.

Shaw, Timothy M. "Southern Africa: Co-Operation and Conflict in an International SubSystem." The Journal of Modern African Studies 12, no. 4 (1974): 633-55. 
Shepard, Wade. "Beijing to the World: Don't Call the Belt and Road Initiative OBOR." Forbes, 2017. https://www.forbes.com/sites/wadeshepard/2017/08/01/beijing-tothe-world-please-stop-saying-obor/\#212d77dc17d4.

Singh, J. S. "From Hindu Monarchy to Secular Republic: Challenges before Nepal's Constituent Assembly." India Quarterly: A Journal of International Affairs 65, no. 3 (2010): 295-311.

Singh, Sinderpal. India in South Asia: Domestic Identity Politics and Foreign Policy from Nehru to the BJP. New York, NY: Routledge, 2015.

Simutis, Anicetas. "Buffer States: A Worn-out Myth.” America 70, no. 14 (1944): 37677.

Spykman, Nicholas J. "Geography and Foreign Policy, I." The American Political Science Review 32, no.1 (1938): 28-50.

Stewart-Ingersoll, Robert, and Derrick Frazier. "India as a Regional Power: Identifying the Impact of Roles and Foreign Policy Orientation on the South Asian Security Order." Asian Security 6, no. 1 (2010): 51-73.

Stratton, Allegra and Agencies. "Tibet Protesters Disrupt Olympic Flame Ceremony." The Guardian, 2008. https://www.theguardian.com/world/2008/mar/24/tibet.olympicgames2008.

Strausz-Hupe, Robert. Geopolitics: The Struggle for Space and Power. New York, NY: Putnam, 1942.

Styan, David. "Djibouti: Small State Strategy at a Crossroads" Third World Thematics: A TWQ Journal 1, no. 1 (2017): 79-91.

Thapa, Ganga B, and Jan Sharma. "From Insurgency to Democracy: The Challenges of Peace and Democracy-Building in Nepal." International Political Science Review 30, no. 2 (2009): 205-19.

Thapliyal, Sangeeta. "India's Security Arrangements with Nepal." PhD Dissertation, Jawaharlal Nehru University, 1995. Accessed at the National Archives of India, New Delhi, India on July 4, 2016.

Thies, Cameron G. "Territorial Nationalism in Spatial Rivalries: An Institutionalist Account of the Argentine-Chilean Rivalry." International Interactions: Empirical and Theoretical Research in International Relations 27, no.4 (2001): 399-431.

Thompson, William R. 2001. "Identifying Rivals and Rivalries in World Politics." International Studies Quarterly 45, no.4 (2001): 557-586. 
Thorhallsson, Baldur, and Anders Wivel. "Small States in the European Union: What Do We Know and What Would We Like to Know?" Cambridge Review of International Affairs 19, no. 4 (2006): 651-68.

“Tibetan Riots Spread Outside Region.” The New York Times, 2008. http://www.nytimes.com/2008/03/16/world/asia/16iht-tibet.4.11148124.html.

Tiezzi, Shannon. "China Steps In After Indian Fuel Stops Flowing to Nepal.” The Diplomat, 2015. https://thediplomat.com/2015/10/china-steps-in-after-indian-fuelstops-flowing-to-nepal/.

Tiwari, Chitra. "Red Star over the Himalayas." Current History: A Journal of Contemporary World Affairs 104, no. 683 (2005): 295-99.

Tucker, Fritz. "Jana Andolan: The People's Movement in Nepal." Zeteo: The Journal of Interdisciplinary Writing, Fall 2012.

Tuladhar, Daman R. Contemporary Nepal (1945-1955). Kathmandu, Nepal: Laxmi Publications, 1980. Accessed at the Ministry of Archaeology, Kathmandu, Nepal on $24^{\text {th }}$ June, 2016.

Turmanidze, Tornike. Buffer States: Power Policies, Foreign Policies, and Concepts. New York, NY: Nova Science Publishers, Inc., 2009.

Upadhya, Sanjay. Nepal and the Geo-Strategic Rivalry between India and China. New York, NY: Routledge, 2012.

United Nations Conference on Trade and Development. "Country Fact Sheet: India," 2017. http://unctad.org/sections/dite_dir/docs/wir2017/wir17_fs_in_en.pdf.

United Nations Conference on Trade and Development, "Foreign Direct Investment (FDI)," 2017, http://unctad.org/en/Pages/DIAE/Foreign-Direct-Investment(FDI).aspx

Vayrynen, Raimo. "On the Definition and Measurement of Small Power Status." Cooperation and Conflict 6, no.1 (1971): 91-102.

Veenendaal, Wouter P., and Jack Corbett. "Why Small States Offer Important Answers to Large Questions.” Comparative Political Studies 48, no. 4 (2015): 527-49.

Vital, David. The Inequality of States: A Study of the Small Power in International Relations. Oxford, UK: Clarendon Press, 1972.

Vital, David. The Survival of Small States. London, UK: Oxford University Press, 1971. 
Vivek, Vipul. "India Gives Most Foreign Aid to Bhutan, Bot Its New Priorities Afghanistan and Africa." Scroll, 2017. https://scroll.in/article/835481/india-givesmost-foreign-aid-to-bhutan-not-its-new-priorities-afghanistan-and-africa.

Walt, Stephen M. “China's New Strategy.” Foreign Policy, 2010. http://foreignpolicy.com/2010/04/26/chinas-new-strategy/.

Watts, Jonathan. "Beijing Locks down Lhasa as Crisis Grows." The Guardian, 2008. https://www.theguardian.com/world/2008/mar/16/tibet.china.

Wheeler, Stephen. The Ameer Abdur Rahman. London, UK: Bliss, Sands, and Foster, 1895.

Whelpton, John. "Nepal and Bhutan in 2008: A New Beginning?" Asian Survey 49, no. 1 (2008): 53-58.

Wilson, William T. “China's Huge 'One Belt, One Road' Initiative Is Sweeping Central Asia.” The Heritage Foundation, 2016. http://www.heritage.org/asia/commentary/chinas-huge-one-belt-one-roadinitiative-sweeping-central-asia.

Wivel, Anders, Alyson J.K. Bailes, and Clive Archer. "Setting the Scene: Small States and International Security." In Small States and International Security: Europe and Beyond, edited by Clive Archer, Alyson J.K. Bailes, and Anders Wivel (New York, NY: 2014), 3-25. New York, NY: Routledge, 2014.

Ziring, Lawrence. "Buffer States on the Rim of Asia: Pakistan, Afghanistan, Iran and the Superpowers." In Soviet-American Relations with Pakistan, Iran and Afghanistan, edited by Hafeez Malik, 90- 126. New York, NY: Palgrave Macmillan, 1987. 


\section{APPENDIX}

APPENDIX 1: Results for Kruskal Wallis Test for Total Trade

\section{NPar Tests}

\section{Kruskal-Wallis Test}

\section{Ranks}

\begin{tabular}{|l|l|r|r|}
\hline & Juncture point & N & Mean Rank \\
\hline & 1 & 5 & 7.20 \\
Totalimports & 2 & 5 & 7.80 \\
& 3 & 4 & 7.50 \\
& Total & 14 & \\
\hline \multirow{5}{*}{ Totalexports } & 1 & 5 & 7.60 \\
& 2 & 5 & 8.60 \\
& 3 & 4 & 6.00 \\
& Total & 14 & \\
\hline
\end{tabular}

Test Statistics ${ }^{\mathrm{a}, \mathrm{b}}$

\begin{tabular}{|l|r|r|}
\hline & Totalimports & \multicolumn{1}{|c|}{ Totalexports } \\
\hline Chi-Square & .051 & .863 \\
df & 2 & 2 \\
Asymp. Sig. & .975 & .650 \\
\hline
\end{tabular}

a. Kruskal Wallis Test

b. Grouping Variable: Juncture point 
APPENDIX 2: Results for Kruskal-Wallis Test for all Variables

NPar Tests

Kruskal-Wallis Test

Ranks

\begin{tabular}{|c|c|c|c|}
\hline & Juncture point & $\mathrm{N}$ & Mean Rank \\
\hline \multirow{4}{*}{ China Imports } & 1 & 5 & 8.00 \\
\hline & 2 & 5 & 8.00 \\
\hline & 3 & 4 & 6.25 \\
\hline & Total & 14 & \\
\hline \multirow{4}{*}{ China Exports } & 1 & 5 & 6.70 \\
\hline & 2 & 5 & 9.20 \\
\hline & 3 & 4 & 6.38 \\
\hline & Total & 14 & \\
\hline \multirow{4}{*}{ India Imports } & 1 & 5 & 7.40 \\
\hline & 2 & 5 & 7.60 \\
\hline & 3 & 4 & 7.50 \\
\hline & Total & 14 & \\
\hline \multirow{4}{*}{ India Exports } & 1 & 5 & 7.60 \\
\hline & 2 & 5 & 8.60 \\
\hline & 3 & 4 & 6.00 \\
\hline & Total & 14 & \\
\hline \multirow{4}{*}{ China FDI } & 1 & 4 & 7.38 \\
\hline & 2 & 4 & 5.25 \\
\hline & 3 & 3 & 5.17 \\
\hline & Total & 11 & \\
\hline \multirow{4}{*}{ India FDI } & 1 & 4 & 5.88 \\
\hline & 2 & 4 & 7.00 \\
\hline & 3 & 3 & 4.83 \\
\hline & Total & 11 & \\
\hline \multirow{4}{*}{ China Aid } & 1 & 5 & 6.80 \\
\hline & 2 & 4 & 7.50 \\
\hline & 3 & 4 & 6.75 \\
\hline & Total & 13 & \\
\hline \multirow{4}{*}{ India Aid } & 1 & 5 & 6.50 \\
\hline & 2 & 5 & 7.80 \\
\hline & 3 & 4 & 8.38 \\
\hline & Total & 14 & \\
\hline
\end{tabular}


Test Statistics ${ }^{\mathrm{a}, \mathrm{b}}$

\begin{tabular}{|l|r|r|c|r|r|r|r|r|}
\hline & \multicolumn{1}{|c|}{$\begin{array}{c}\text { China } \\
\text { Imports }\end{array}$} & $\begin{array}{c}\text { China } \\
\text { Exports }\end{array}$ & $\begin{array}{c}\text { India } \\
\text { Imports }\end{array}$ & $\begin{array}{c}\text { India } \\
\text { Exports }\end{array}$ & $\begin{array}{c}\text { China } \\
\text { FDI }\end{array}$ & $\begin{array}{c}\text { India } \\
\text { FDI }\end{array}$ & $\begin{array}{c}\text { China } \\
\text { Aid }\end{array}$ & $\begin{array}{c}\text { India } \\
\text { Aid }\end{array}$ \\
\hline Chi-Square & .500 & 1.301 & .006 & .863 & 1.086 & .744 & .096 & .487 \\
df & 2 & 2 & 2 & 2 & 2 & 2 & 2 & 2 \\
Asymp. & .779 & .522 & .997 & .650 & .581 & .689 & .953 & .784 \\
Sig. & & & & & & & & \\
\hline
\end{tabular}

a. Kruskal Wallis Test

b. Grouping Variable: Juncture point 
APPENDIX 3: Descriptive Statistics for Trade

Descriptive Statistics

Dependent Variable: Trade

\begin{tabular}{|c|c|c|c|c|c|}
\hline Time & IndiaxChina & ExportxImport & Mean & Std. Deviation & $\mathrm{N}$ \\
\hline \multirow[t]{9}{*}{ Pre } & \multirow[t]{3}{*}{ India } & Exports & 312.6620 & 218.47166 & 5 \\
\hline & & Imports & 801.8250 & 841.37427 & 4 \\
\hline & & Total & 530.0678 & 596.48824 & 9 \\
\hline & \multirow[t]{3}{*}{ China } & Exports & 6.7420 & 2.97738 & 5 \\
\hline & & Imports & 330.3000 & 339.48630 & 5 \\
\hline & & Total & 168.5210 & 283.38504 & 10 \\
\hline & \multirow[t]{3}{*}{ Total } & Exports & 159.7020 & 217.28694 & 10 \\
\hline & & Imports & 539.8667 & 620.36435 & 9 \\
\hline & & Total & 339.7800 & 482.37438 & 19 \\
\hline \multirow[t]{9}{*}{ During } & \multirow[t]{3}{*}{ India } & Exports & 337.2940 & 209.37983 & 5 \\
\hline & & Imports & 1209.1400 & 1563.77730 & 5 \\
\hline & & Total & 773.2170 & 1147.81174 & 10 \\
\hline & \multirow[t]{3}{*}{ China } & Exports & 4.5950 & 2.57740 & 4 \\
\hline & & Imports & 325.7800 & 331.25503 & 5 \\
\hline & & Total & 183.0311 & 289.00335 & 9 \\
\hline & \multirow[t]{3}{*}{ Total } & Exports & 189.4278 & 229.49790 & 9 \\
\hline & & Imports & 767.4600 & 1162.91442 & 10 \\
\hline & & Total & 493.6553 & 887.42335 & 19 \\
\hline \multirow[t]{9}{*}{ Post } & \multirow[t]{3}{*}{ India } & Exports & 231.6600 & 158.03142 & 4 \\
\hline & & Imports & 1236.7400 & 1379.10679 & 5 \\
\hline & & Total & 790.0378 & 1113.97494 & 9 \\
\hline & \multirow[t]{3}{*}{ China } & Exports & 12.0320 & 9.47837 & 5 \\
\hline & & Imports & 188.9250 & 149.50749 & 4 \\
\hline & & Total & 90.6511 & 130.83992 & 9 \\
\hline & \multirow[t]{3}{*}{ Total } & Exports & 109.6444 & 151.02702 & 9 \\
\hline & & Imports & 771.0444 & 1124.42283 & 9 \\
\hline & & Total & 440.3444 & 849.41543 & 18 \\
\hline \multirow[t]{9}{*}{ Total } & \multirow[t]{3}{*}{ India } & Exports & 298.3157 & 189.65524 & 14 \\
\hline & & Imports & 1102.6214 & 1241.01868 & 14 \\
\hline & & Total & 700.4686 & 962.58926 & 28 \\
\hline & \multirow[t]{3}{*}{ China } & Exports & 8.0179 & 6.50630 & 14 \\
\hline & & Imports & 288.2929 & 280.42909 & 14 \\
\hline & & Total & 148.1554 & 241.35075 & 28 \\
\hline & \multirow[t]{3}{*}{ Total } & Exports & 153.1668 & 197.95797 & 28 \\
\hline & & Imports & 695.4571 & 975.36127 & 28 \\
\hline & & Total & 424.3120 & 749.07290 & 56 \\
\hline
\end{tabular}




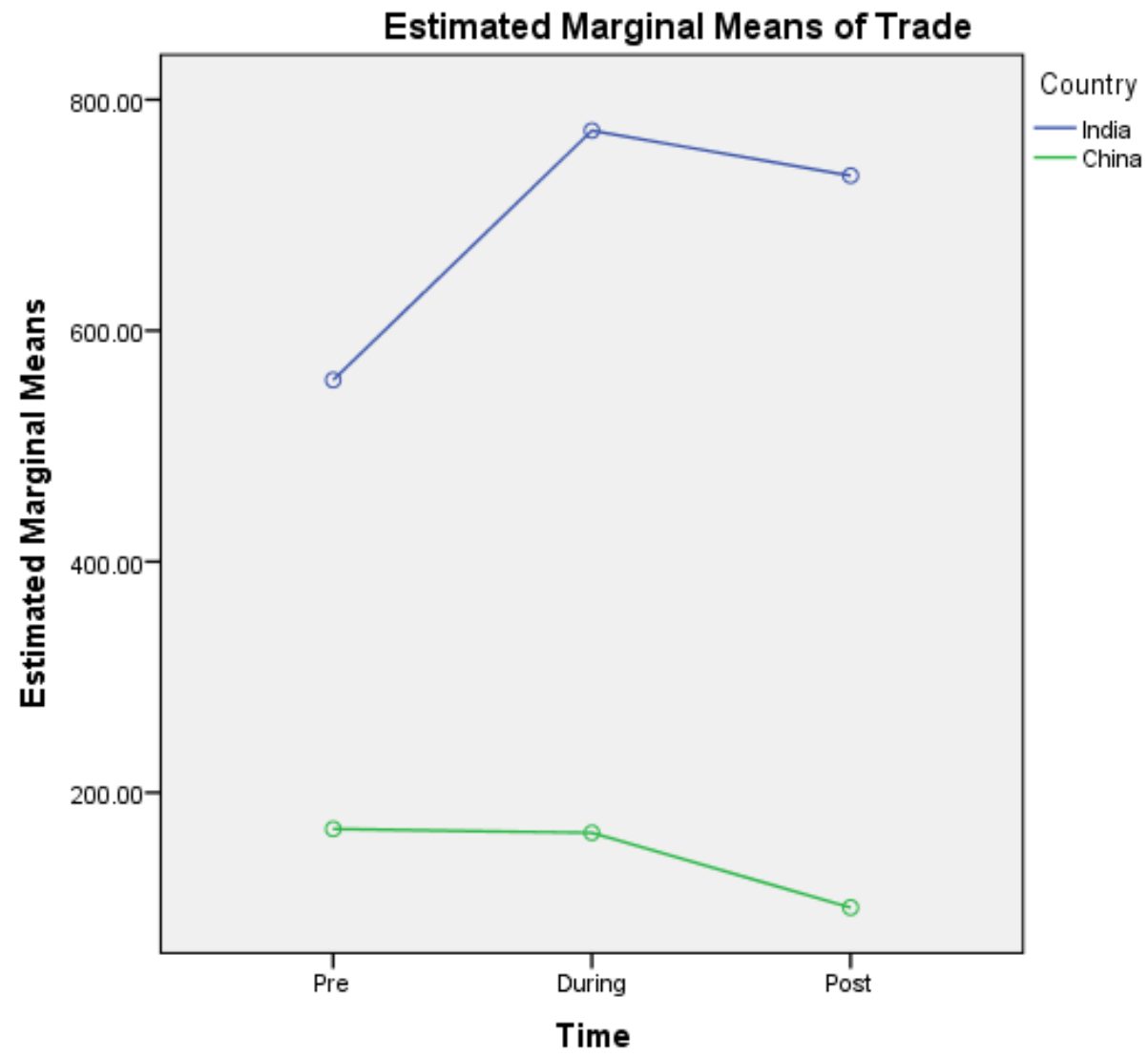


Appendix 4: Descriptive Statistics for FDI

Descriptive Statistics

\begin{tabular}{|l|r|r|r|r|}
\hline Dependent Variable: & FDI & Mean & Std. Deviation & $\mathrm{N}$ \\
\hline \multirow{2}{*}{ Country } & Time & 21.1075 & 29.70471 & 4 \\
& Pre & 90.3100 & 165.70635 & 4 \\
& During & 8.0167 & 9.63823 & 3 \\
& Post & 42.7018 & 99.87456 & 11 \\
\hline China & Total & 33.8925 & 37.82066 & 4 \\
& Pre & 23.8450 & 26.99763 & 4 \\
& During & 20.9667 & 35.01893 & 3 \\
& Post & 26.7136 & 30.44440 & 11 \\
\hline Total & Total & 27.5000 & 32.21629 & 8 \\
& Pre & 57.0775 & 115.50980 & 8 \\
& During & 14.4917 & 24.04161 & 6 \\
& Post & 34.7077 & 72.51398 & 22 \\
\hline
\end{tabular}

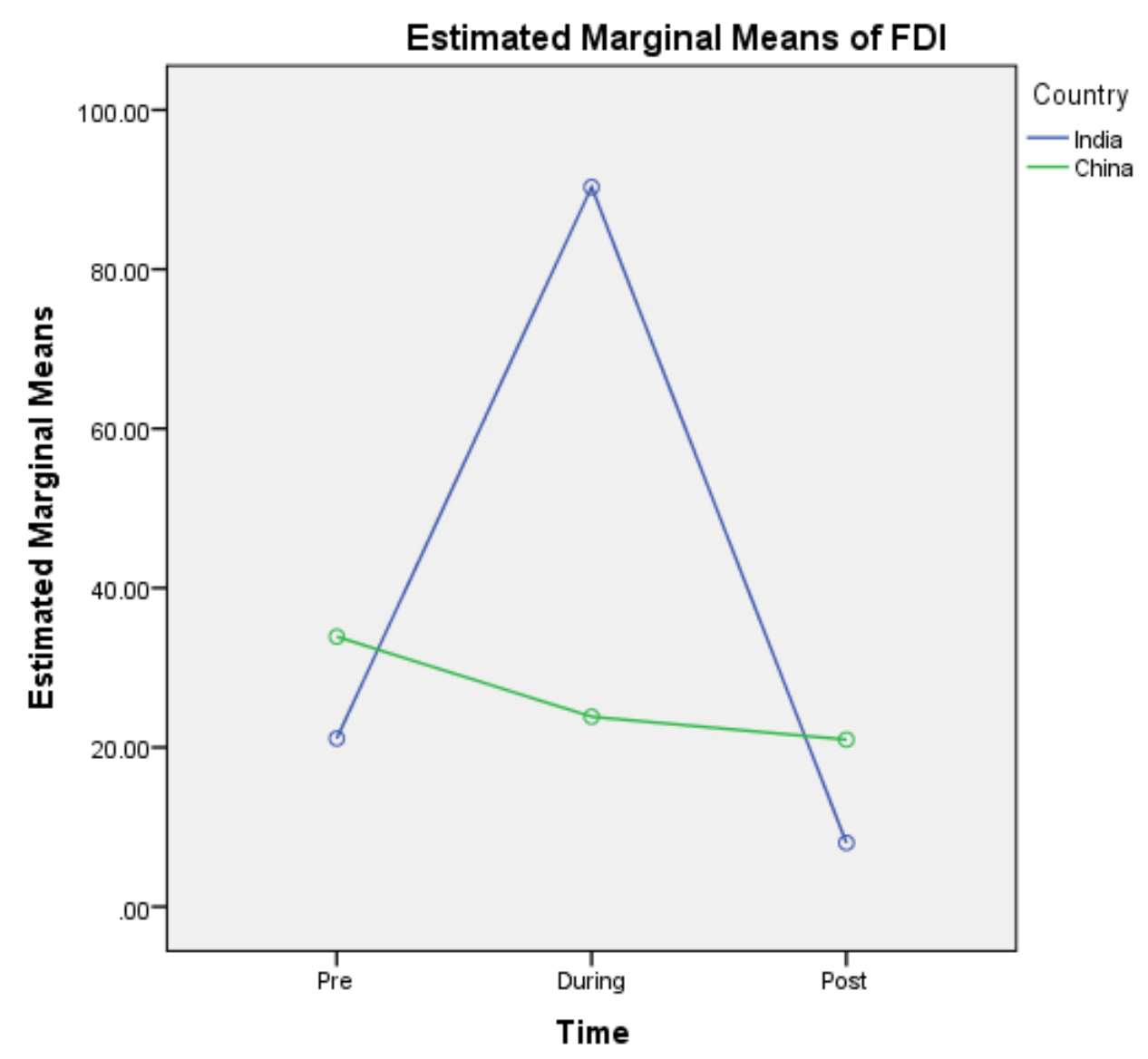


Appendix 5: Descriptive Statistics for Foreign Aid

\begin{tabular}{|c|c|c|c|c|}
\hline \multicolumn{5}{|c|}{ Descriptive Statistics } \\
\hline \multicolumn{5}{|c|}{ Dependent Variable: Aid } \\
\hline Country & Time & Mean & Std. Deviation & $\mathrm{N}$ \\
\hline \multirow[t]{4}{*}{ India } & Pre & 26487830.5824 & 20169058.57678 & 5 \\
\hline & During & 308986747.2490 & 637266042.60885 & 5 \\
\hline & Post & 29628183.8575 & 15928844.95120 & 4 \\
\hline & Total & 128277544.6134 & 380367431.54664 & 14 \\
\hline \multirow[t]{4}{*}{ China } & Pre & 1044971232.7500 & 1838926484.23039 & 4 \\
\hline & During & 198304450.1450 & 193288409.62313 & 4 \\
\hline & Post & 1343096372.3333 & 2130070576.05820 & 3 \\
\hline & Total & 818399258.9618 & 1479890715.43564 & 11 \\
\hline \multirow[t]{4}{*}{ Total } & Pre & 479147120.4347 & 1247583107.18489 & 9 \\
\hline & During & 259794615.2028 & 469539236.24721 & 9 \\
\hline & Post & 592543121.7757 & 1416135937.29415 & 7 \\
\hline & Total & 431931098.9267 & 1055055449.48426 & 25 \\
\hline
\end{tabular}

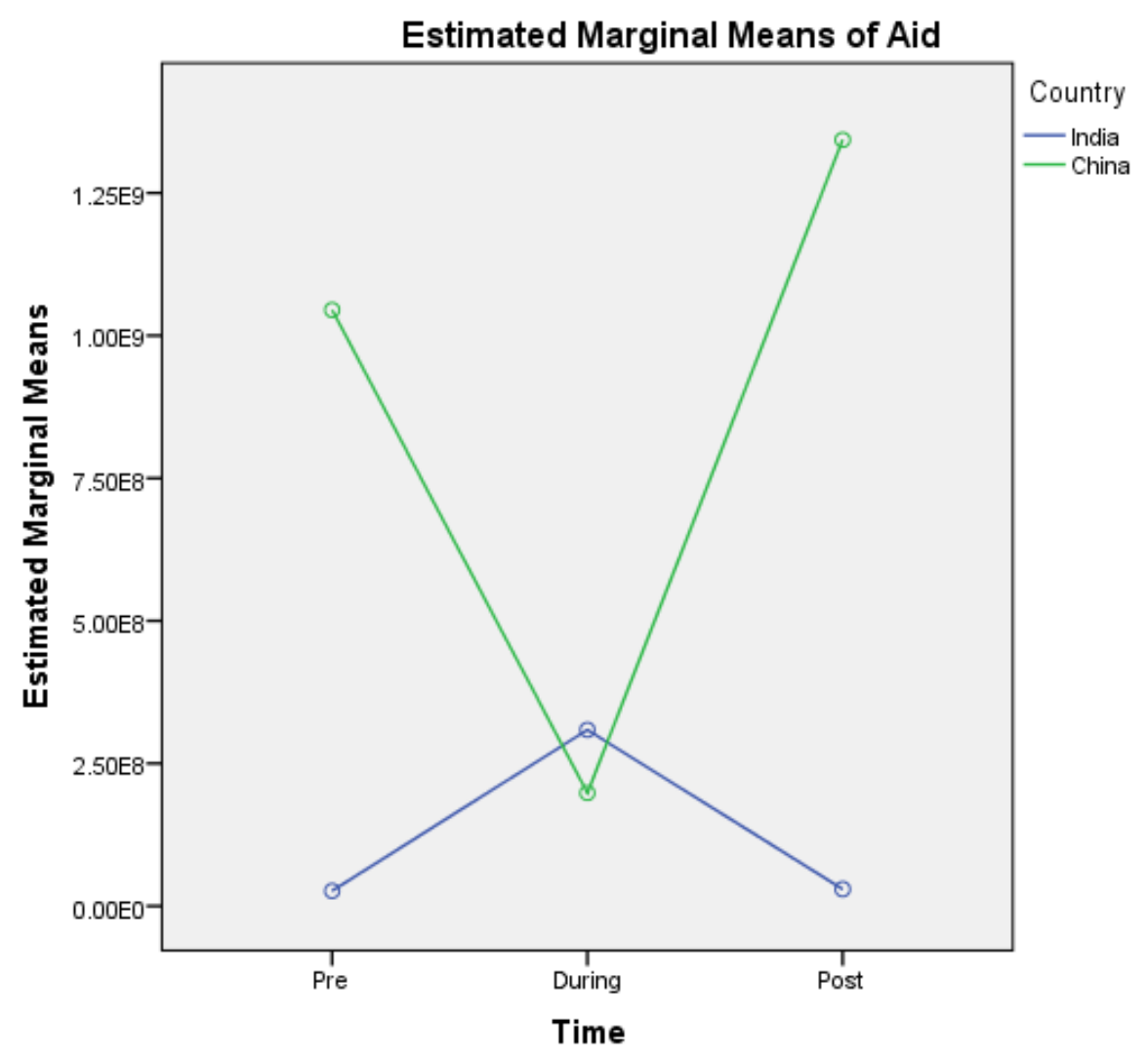


Appendix 6: Results of Correlations

\section{Nonparametric Correlations}

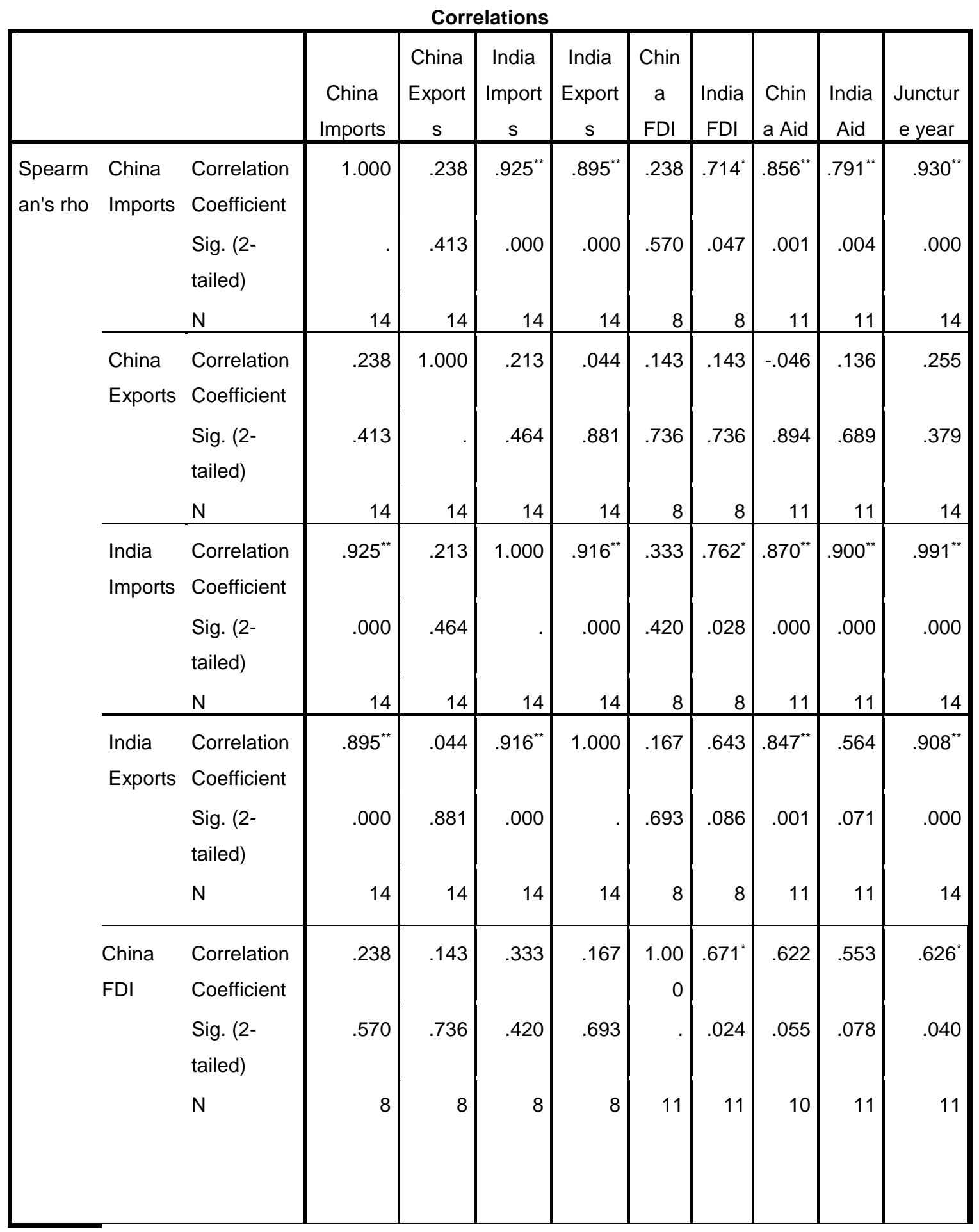




\begin{tabular}{|c|c|c|c|c|c|c|c|c|c|c|}
\hline $\begin{array}{l}\text { India } \\
\text { FDI }\end{array}$ & $\begin{array}{l}\text { Correlation } \\
\text { Coefficient } \\
\text { Sig. (2- } \\
\text { tailed) } \\
\mathrm{N}\end{array}$ & $\begin{array}{r}.714^{*} \\
.047 \\
8 \\
\end{array}$ & $\begin{array}{l}.143 \\
.736\end{array}$ & $\begin{array}{l}.762^{*} \\
.028\end{array}$ & $\begin{array}{l}.643 \\
.086\end{array}$ & $\begin{array}{l}.671^{\star} \\
.024\end{array}$ & $\begin{array}{r}1.00 \\
0\end{array}$ & $\begin{array}{r}.829^{*} \\
.003\end{array}$ & $\begin{array}{r}.689^{*} \\
.019 \\
11 \\
\end{array}$ & $\begin{array}{r}.017 \\
11 \\
\end{array}$ \\
\hline $\begin{array}{l}\text { China } \\
\text { Aid }\end{array}$ & $\begin{array}{l}\text { Correlation } \\
\text { Coefficient } \\
\text { Sig. (2- } \\
\text { tailed) } \\
\mathrm{N}\end{array}$ & $\begin{array}{r}.856^{* *} \\
.001 \\
\\
11 \\
\end{array}$ & $\begin{array}{r}-.046 \\
.894\end{array}$ & $\begin{array}{r}.870^{* *} \\
.000 \\
11 \\
\end{array}$ & $\begin{array}{r}.847^{* *} \\
.001 \\
11 \\
\end{array}$ & $\begin{array}{c}.622 \\
.055 \\
10 \\
\end{array}$ & $\begin{array}{r}.829 \\
* * \\
.003\end{array}$ & $\begin{array}{r}1.00 \\
0\end{array}$ & $\begin{array}{r}.808^{*} \\
. \\
.001 \\
13 \\
\end{array}$ & $\begin{array}{l}.927^{* *} \\
.000\end{array}$ \\
\hline $\begin{array}{l}\text { India } \\
\text { Aid }\end{array}$ & $\begin{array}{l}\text { Correlation } \\
\text { Coefficient } \\
\text { Sig. (2- } \\
\text { tailed) } \\
\mathrm{N}\end{array}$ & $\begin{array}{r}.791^{* *} \\
.004 \\
\\
11 \\
\end{array}$ & $\begin{array}{l}.136 \\
.689\end{array}$ & $\begin{array}{r}.900^{* *} \\
.000 \\
11 \\
\end{array}$ & $\begin{array}{c}.564 \\
.071 \\
\\
11 \\
\end{array}$ & $\begin{array}{r}.553 \\
.078 \\
\\
11 \\
\end{array}$ & $\begin{array}{r}.689 \\
* \\
.019\end{array}$ & $\begin{array}{r}.808^{*} \\
* \\
.001 \\
13 \\
\end{array}$ & $\begin{array}{r}1.00 \\
0\end{array}$ & $\begin{array}{r}.930^{* *} \\
.000 \\
14 \\
\end{array}$ \\
\hline $\begin{array}{l}\text { Junctur } \\
\text { e year }\end{array}$ & $\begin{array}{l}\text { Correlation } \\
\text { Coefficient } \\
\text { Sig. (2- } \\
\text { tailed) } \\
\mathrm{N}\end{array}$ & $\begin{array}{r}.930^{* *} \\
.000 \\
14\end{array}$ & $\begin{array}{r}.255 \\
.379 \\
14\end{array}$ & $\begin{array}{r}.991^{* *} \\
.000 \\
14\end{array}$ & $\begin{array}{r}.908^{* *} \\
.000 \\
14\end{array}$ & $\begin{array}{r}.626^{*} \\
.040 \\
\\
11\end{array}$ & $\begin{array}{r}.699 \\
* \\
.017 \\
11\end{array}$ & $\begin{array}{r}.927^{*} \\
.000 \\
.\end{array}$ & $\begin{array}{r}.930^{*} \\
* \\
.000 \\
\\
14\end{array}$ & 1.000 \\
\hline
\end{tabular}

${ }^{*}$. Correlation is significant at the 0.01 level (2-tailed).

${ }^{*}$. Correlation is significant at the 0.05 level (2-tailed). 


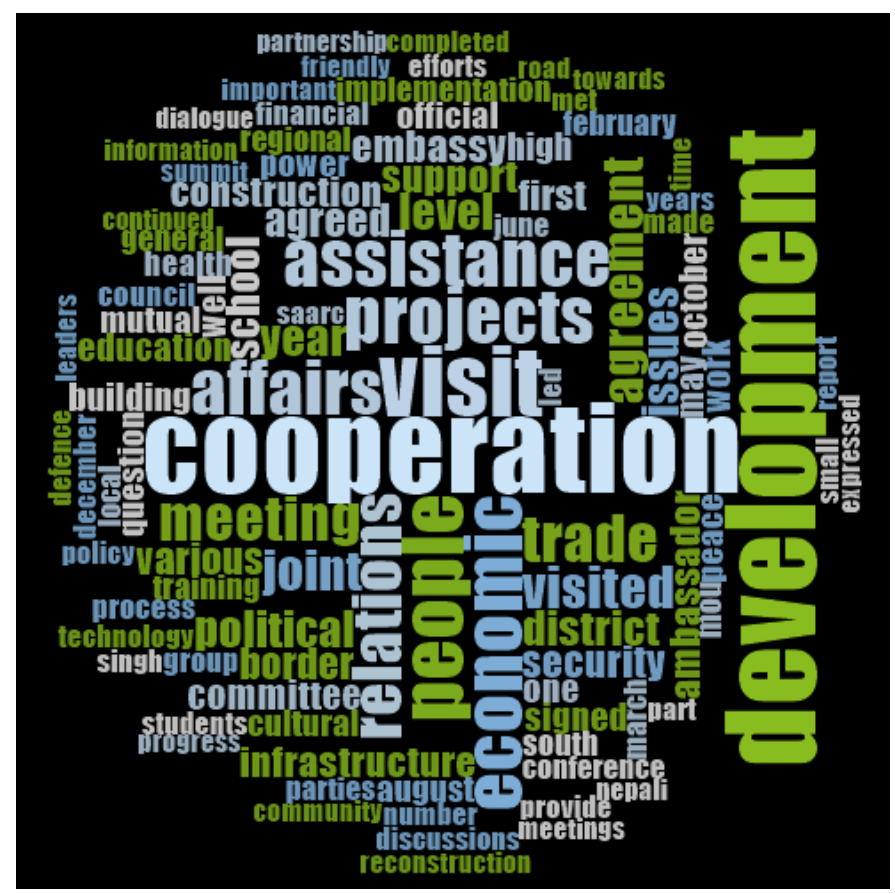

APPENDIX 8: Word Cloud for all Pre-Critical Juncture Qualitative Data

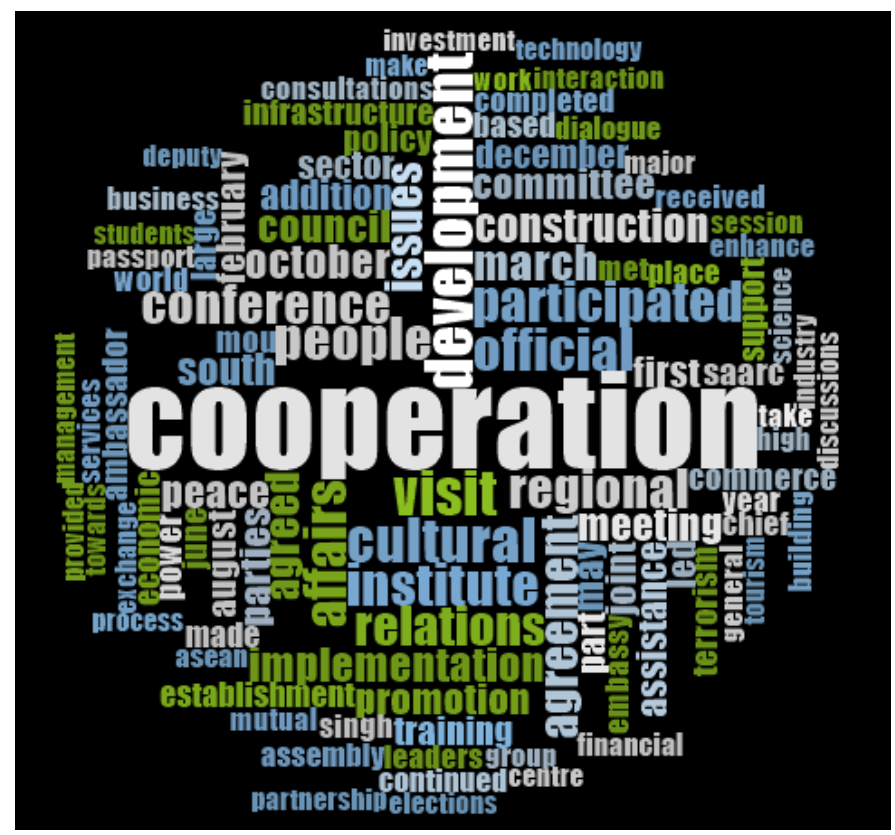


APPENDIX 9: Word Cloud for all during Critical Juncture Qualitative Data

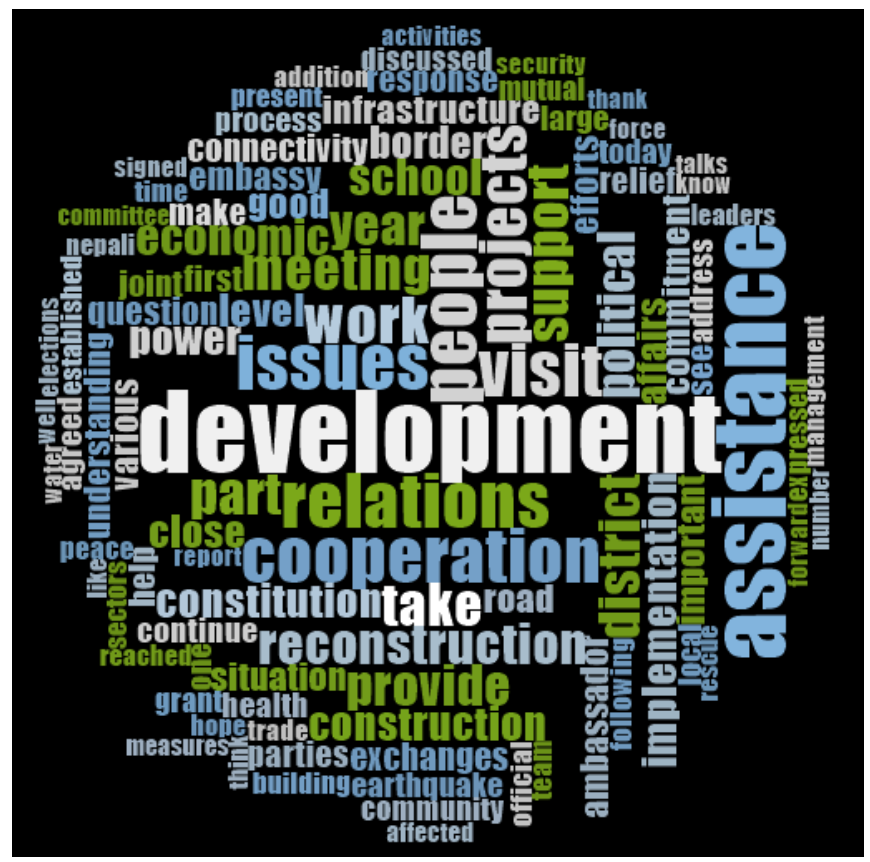

APPENDIX 10: Word Cloud for all Post-Critical Juncture Qualitative Data

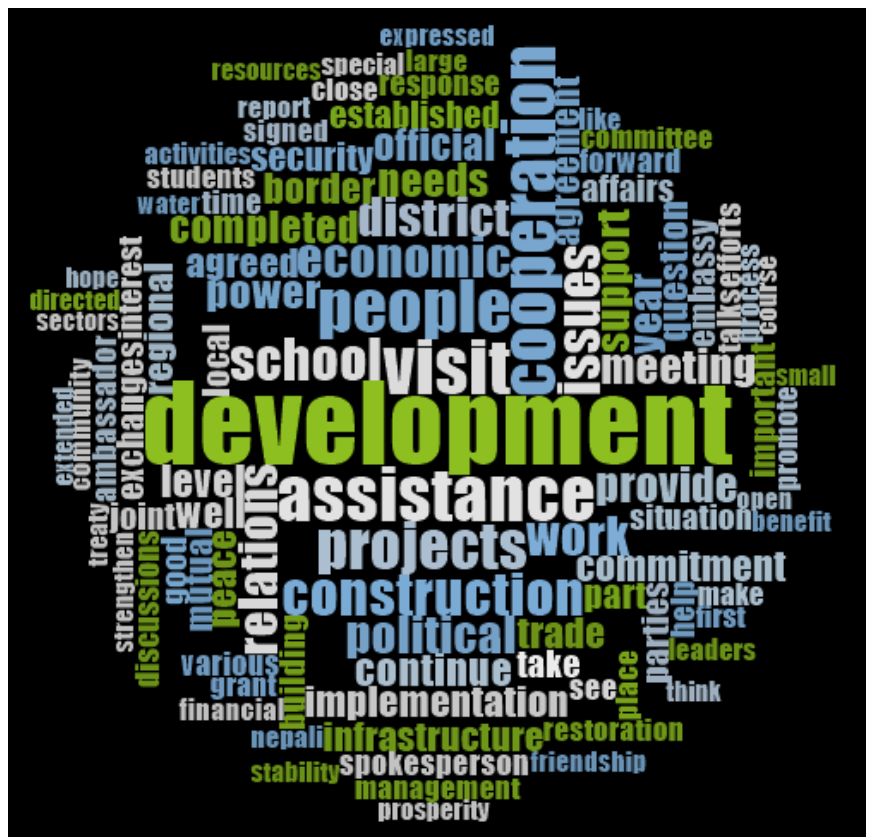


APPENDIX 11: Word Cloud for all India-Nepal Data

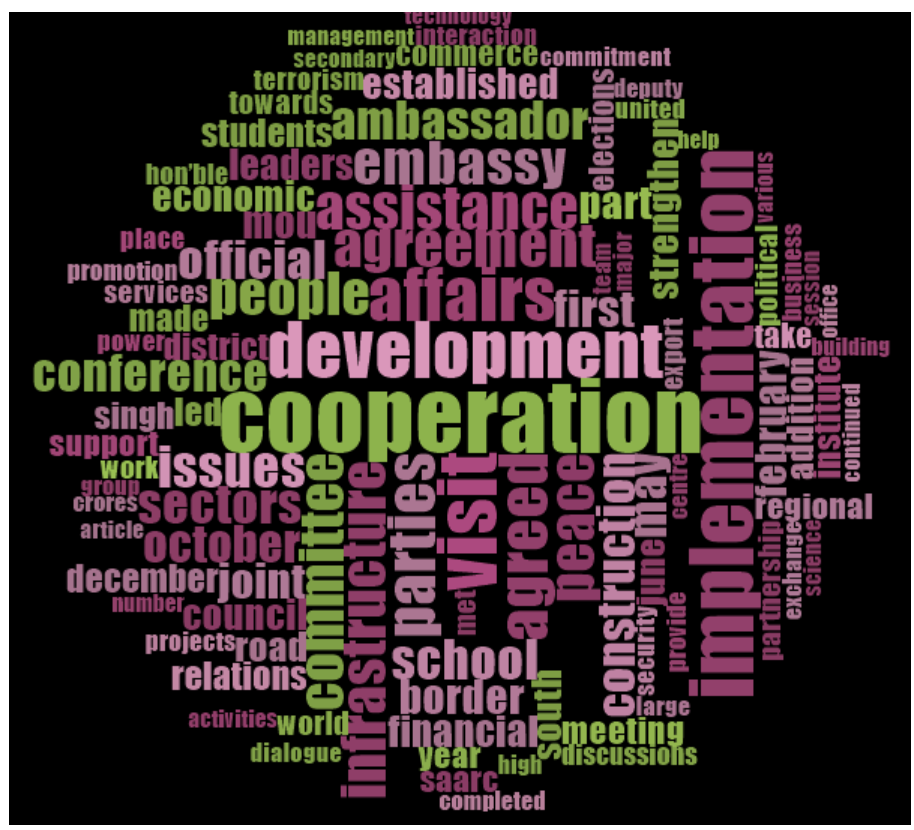

APPENDIX 12: Word Cloud for Pre-Critical Juncture India-Nepal Data

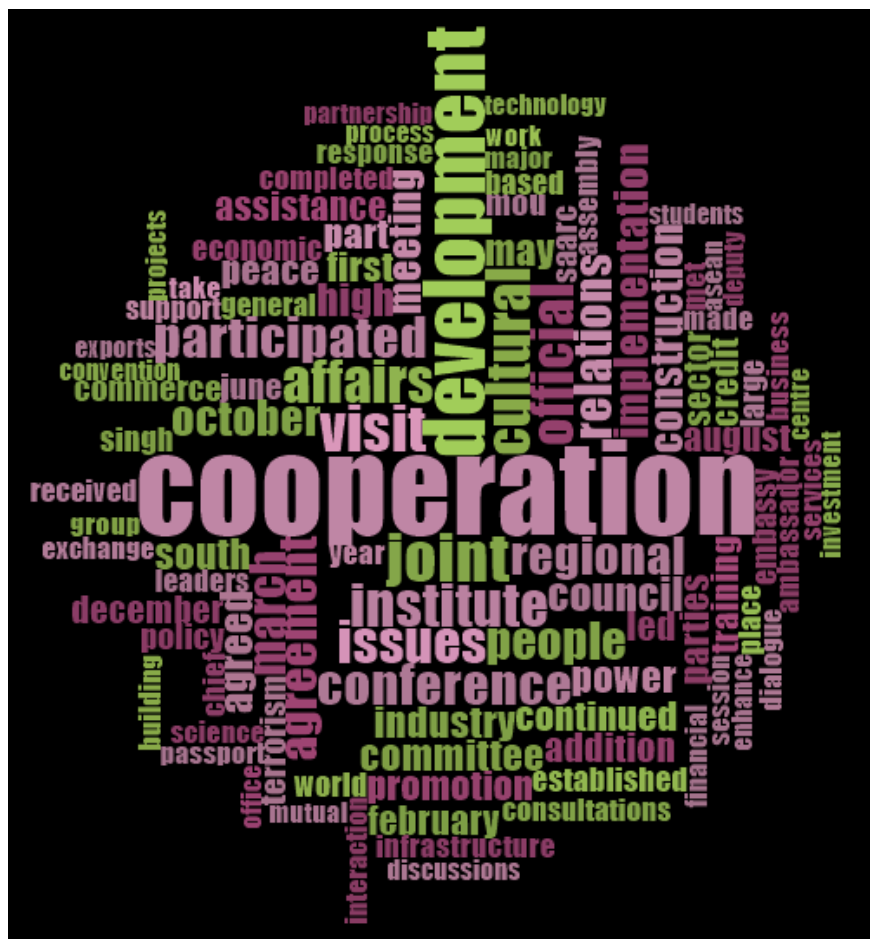


APPENDIX 13: Word Cloud for during-Critical Juncture India-Nepal Data

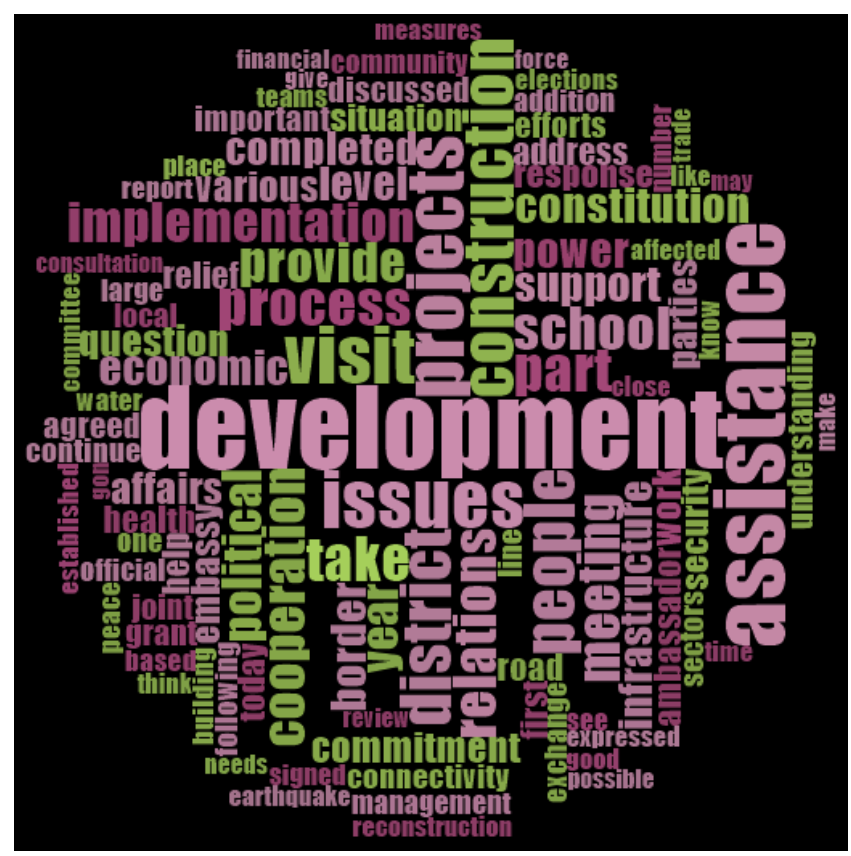

APPENDIX 14: Word Cloud for Post-Critical Juncture India-Nepal Data

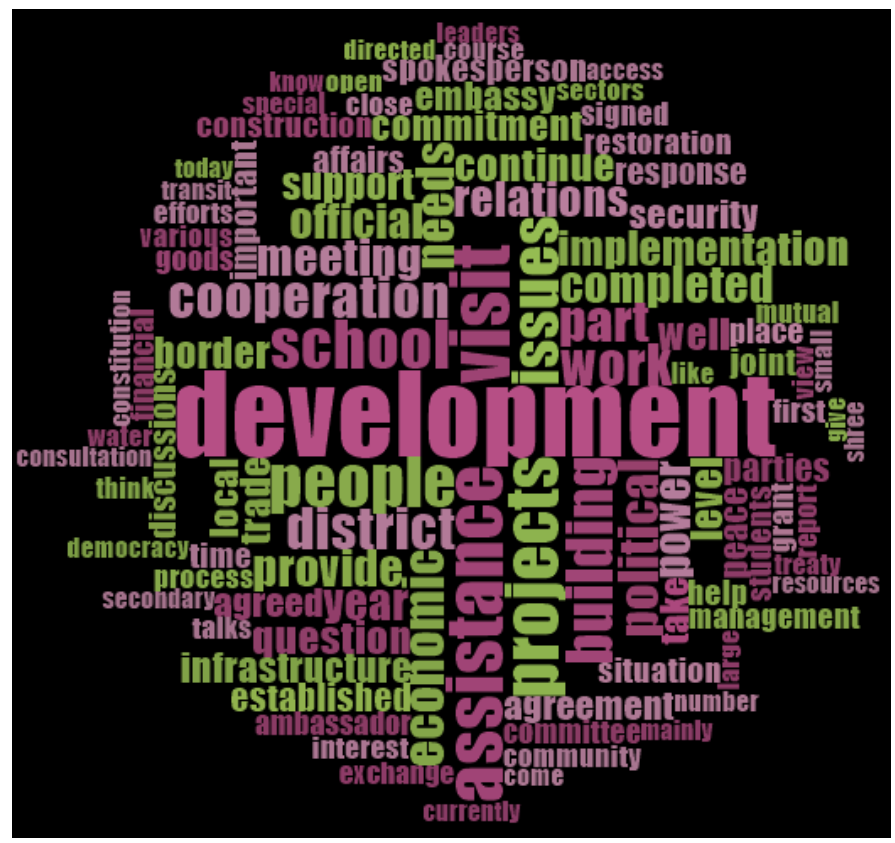


APPENDIX 15: Word Cloud for all China-Nepal Data

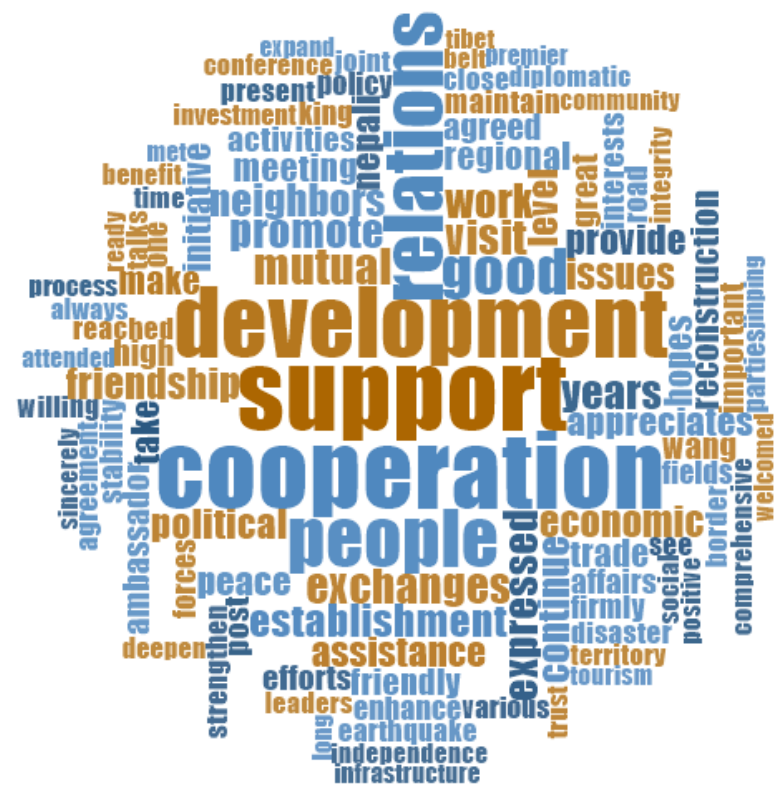

APPENDIX 16: Word Cloud for Pre-Critical Juncture China-Nepal Data

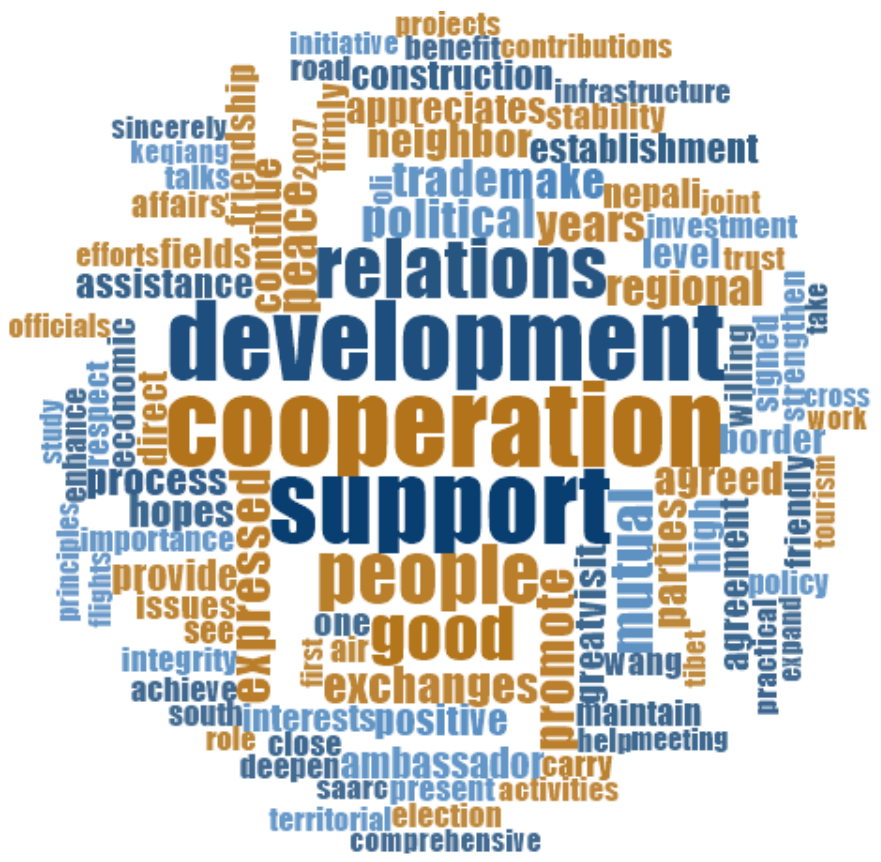


APPENDIX 17: Word Cloud for Pre-Critical Juncture China-Nepal Data

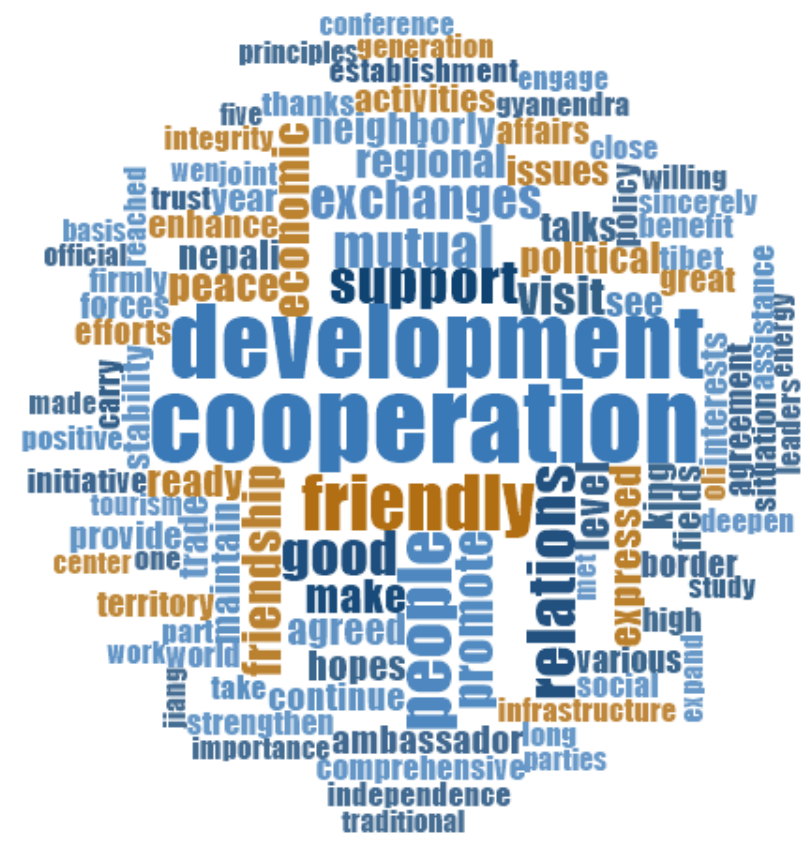

APPENDIX 18: Word Cloud for Pre-Critical Juncture China-Nepal Data

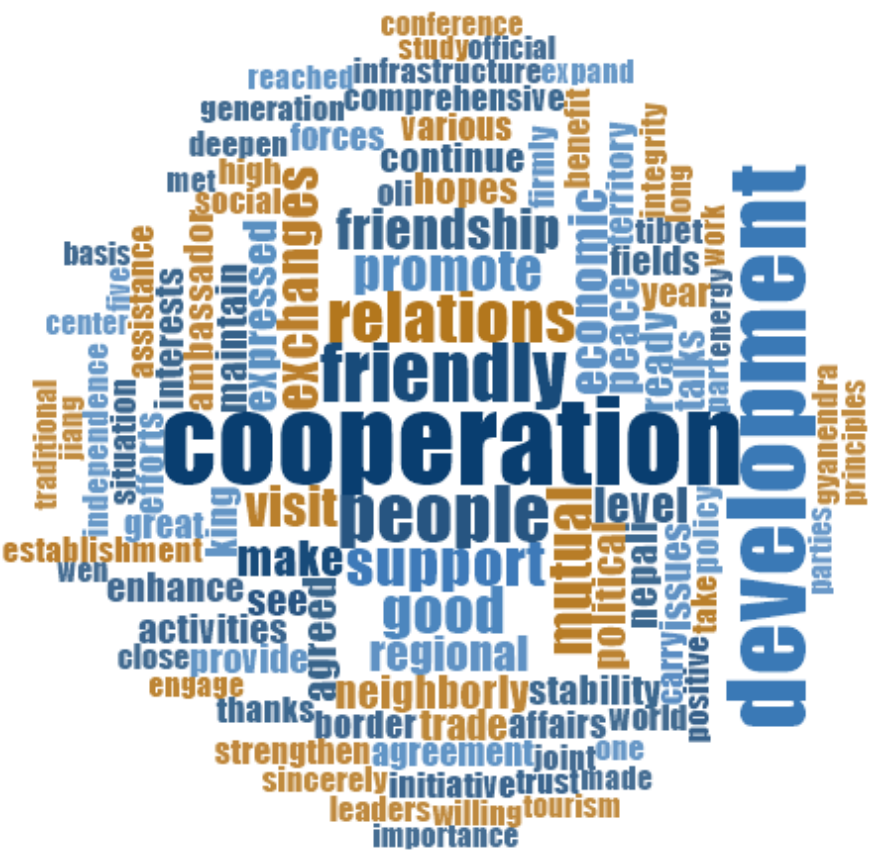


VITA

\section{BIBEK CHAND}

Born: Lalitpur, Bagmati Zone, Nepal

2008-2012

B.A., Political Science, International Relations

Minors: History, Intercultural Studies

Wartburg College

Waverly, Iowa, USA

2012-2015

M.A., International Studies

Florida International University

Miami, Florida, USA

2012-2017

Teaching Assistant

Department of Politics and International Relations

Florida International University

2012-2018

Doctoral Candidate

Department of Politics and International Relations

Florida International University

2016-18

Fellowship Recipient

Dissertation Year Fellowship (DYF), University Graduate School Florida International University

Doctoral Evidence Acquisition (DEA), University Graduate School

Florida International University

Morris \& Anita Broad Fellowship, Green SIPA

Florida International University

\section{PUBLICATIONS AND PRESENTATIONS}

"Dynamics of Rivalry between Regional Powers: Implications of Geographic Contiguity for Sino-Indian Relations.” Asian Politics \& Policy, (2018). (Forthcoming).

"Disaster Relief as a Political Tool: Analysing Indian and Chinese Responses after the Nepal Earthquakes.” Strategic Analysis 41, no.6 (2017), pp. 535-545.

"Between a Rock and a Hard Place: Border Minorities in China's Foreign Relations with South Asia." Journal of Borderlands Studies, (2017). Published online (with Lukas Danner). 
"Power Politics and Securitization: The Indo-Japanese Nexus in Southeast Asia." Asia \& the Pacific Policy Studies 4, no.2 (2017), pp. 310-324 (with Zenel Garcia).

Review Essay: “China's Engagement with its Periphery." Journal of Asian Security and International Affairs 4, no.2 (2017), pp.239-248.

Book Review: Andrew Small. "The China-Pakistan Axis: Asia's New Geopolitics." Journal of Asian Security and International Affairs 4, no.3 (2017), 357-360. http://journals.sagepub.com/doi/pdf/10.1177/2347797017730160

"Implications of the Dragon's Rise for South Asia: Assessing China's Nepal Policy." Strategic Analysis 40, no.1 (2016), pp. 26-40 (with Lukas Danner).

Book Review:_Bhumitra Chakma. "South Asia's Nuclear Security." Journal of Asian Security and International Affairs 2, no.3 (2015), pp. 341-43.

http://dx.doi.org/10.1177/2347797015601919

Book Review:_T.V. Paul. "The Warrior State: Pakistan in the Contemporary World." South Asia: Journal of South Asian Studies 38, no.3 (2015), pp.538-39. http://dx.doi.org/10.1080/00856401.2015.1057930

"A Marriage of Strategic Convenience: The Development of Indo-Vietnamese Partnership and Implications for the South China Sea Dispute." International Studies Association Annual Meeting, San Francisco, CA, April 2018.

"Assessing Modi's Neighborhood First Policy: The China Factor in Indo-Nepalese Relations." International Studies Association International Conference, Hong Kong, June 15-18, 2017.

Ten other papers presented at the annual conferences of the International Studies Association (ISA), ISA-South, Midwest Political Science Association, Florida Political Science Association, Jean Monnet Center of Excellence, South Florida Latin American \& Caribbean Studies Graduate Student Conference, American Association for Chinese Studies and Global International Studies Conference of the World International Studies Committee. 